\title{
Toxicology of the food additives BHA and BHT
}

Citation for published version (APA):

Verhagen, F. J. J. (1989). Toxicology of the food additives BHA and BHT. [Doctoral Thesis, Maastricht University]. Datawyse / Universitaire Pers Maastricht. https://doi.org/10.26481/dis.19890929fv

Document status and date:

Published: 01/01/1989

DOI:

10.26481/dis.19890929fv

Document Version:

Publisher's PDF, also known as Version of record

\section{Please check the document version of this publication:}

- A submitted manuscript is the version of the article upon submission and before peer-review. There can be important differences between the submitted version and the official published version of record.

People interested in the research are advised to contact the author for the final version of the publication, or visit the DOI to the publisher's website.

- The final author version and the galley proof are versions of the publication after peer review.

- The final published version features the final layout of the paper including the volume, issue and page numbers.

Link to publication

\footnotetext{
General rights rights.

- You may freely distribute the URL identifying the publication in the public portal. please follow below link for the End User Agreement:

www.umlib.nl/taverne-license

Take down policy

If you believe that this document breaches copyright please contact us at:

repository@maastrichtuniversity.nl

providing details and we will investigate your claim.
}

Copyright and moral rights for the publications made accessible in the public portal are retained by the authors and/or other copyright owners and it is a condition of accessing publications that users recognise and abide by the legal requirements associated with these

- Users may download and print one copy of any publication from the public portal for the purpose of private study or research.

- You may not further distribute the material or use it for any profit-making activity or commercial gain

If the publication is distributed under the terms of Article $25 \mathrm{fa}$ of the Dutch Copyright Act, indicated by the "Taverne" license above, 
Dit proefschrift is gerealiseerd door de Universitaire Pers Maastricht, in samenwerking met de afdeling Reprografie en de Audiovisuele Dienst van de RL.

Coördinatie:

Universitaire Pers Maastricht

tel. (043) 887122

Druk:

Reprografie RL

tel. (043) 888325

Ontwerp omslag:

Audiovisuele Dienst RL

tel. (043) 888244 
The author is grateful to the European BHT Manufacturers Association (EBMA) for its contribution and material assistance lowards the publication of this thesis. He would like to stress that the conclusions reached in it are his own and do not necessarily represent the views and opinion of EBMA. 


\section{TOXICOLOGY OF THE FOOD}

ADDITIVES BHA AND BHT 


\title{
TOXICOLOGY OF THE FOOD ADDITIVES BHA AND BHT
}

\author{
PROEFSCHRIFT
}

ter verkrijging van de graad van doctor

aan de Rijksuniversiteit Limburg te Maastricht, op gezag van de Rector Magnificus, Prof. Dr. F.I.M. Bonke, volgens het besluit van het College van Dekanen,

in het openbaar te verdedigen op vrijdag, 29 september 1989 om 14.00 uur

door

Franciscus Johannes Josephus Verhagen

geboren te Helmond op 23 november 1957 
Promiotores:

Co-promotor:

Beoordelingscommissie:
Prof. Dr. F. ten Hoor

Prof. Dr. P. Th. Henderson

Dr. J.C.S. Kleinjans

Prof. Dr. H.A.J. Struyker Boudier, voorzitter Prof. Dr. P.J. Brombacher

Prof. Dr. V.J. Feron

Prof. Dr. Ir. R.J.J. Hermus

Dr. H.H.W. Thijssen

\section{CIP-GEGEVENS KONINKLIJKE BIBLIOTHEEK, DEN HAAG}

Verhagen, Hans

Toxicology of the food additives BHA and BHT/

Franciscus Johannes Josephus Verhagen.

Maastricht: Universitaire Pers Maastricht. -IIl.

Proefschrift Maastricht. - Met lit. opg., reg.

ISBN 90-5278-002-1

SISO 628.9 UDC 615.9:641.1(043.3) NUGI 743

Trefw.: toxicologie; voedingsadditieven. 
Met één touwtje kun je een marionet niet bespelen.

Frank Herbert 


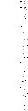




\section{Contents}

Abbreviations

1 General introduction

1.1 Toxicological risk assessment. 13

1.2 General aspects of BHA and BHT.

1.3 Prevention of lipid peroxidation in foods by antioxidants. 18

1.4 Toxicity of BHA and BHT. $\quad 22$

$\begin{array}{ll}1.5 \text { Biological and biochemical actions. } & 22\end{array}$

1.6 Carcinogenicity of BHA and BHT in animals. 26

$\begin{array}{lll}1.7 & \text { Data on BHA and BHT in man. } & 27\end{array}$

1.8 The present ADI's for BHA and BHT. 27

1.9 Aim of the thesis. $\quad 31$

1.10 Outline of the thesis.

Part I: Analytical procedures

2 Sensitive high-performance liquid chromatographic method for the routine determination of butylated hydroxyanisole in plasma. $\quad 43$

3 Determination of butylated hydroxytoluene in plasma by high-performance liquid chromatography. $\quad 49$

4 Rapid determination of isomer ratios of butylated hydroxyanisole by high-performance liquid chromatography. 55

Part II: Metabolism and kinetics of BHA and BHT in man and rat

5 Disposition of single oral doses of butylated hydroxyanisole in man and rat. $\quad 61$

6 Biliary excretion of butylated hydroxyanisole in the rat.

7 Disposition of single oral doses of butylated hydroxytoluene in man and rat. $\quad 77$

Part III: A human toxicity study with BHA

8 Effect of subacute oral intake of the food antioxidant butylated hydroxyanisole on clinical parameters and phase-J and -II biotransformation capacity in man. 
Part IV: Studies on the mechanism of carcinogenicity of BHA and BHT 107

9 Butylated hydroxyanisole, butylated hydroxytoluene, and tert-butylhydroquinone are not mutagenic in the Salmonella/microsome assay using new tester strains.

10 Effect of short-term dietary administration of butylated hydroxyanisole on cell kinetic parameters in the rat gastro-intestinal tract, assessed by immunocytochemistry and flow cytometry.

11 Butylated hydroxyanisole-induced alterations in cell kinetic parameters in rat forestomach in relation to its oxidative cytochrome P-450 -mediated metabolism. 123

12 Dose-dependent effects of short-term dietary administration of the food additive butylated hydroxyanisole on cell kinetic parameters in rat gastro-intestinal tract.

Part V: Daily dietary intake of BHA and BHT by man

13. Estimate of the daily dietary intake of butylated hydroxyanisole and butylated hydroxytoluene in The Netherlands.

\section{General discussion}

Summary

Samenvatting

Dankwoord

List of publications

Curriculum vitae 


\section{Abbreviations}

$\mathrm{ADI}$

AP

$\mathrm{AU}$

AUC

AUFS

BDMP

BHA

2-BHA

3-BHA

free-BHA

total-BHA

BHT

BHT-COOH

BrdU

CAS reg. No.

CIAA

$C L$

$\mathrm{Co}$

$\mathrm{CO}$

CV

d

D

DBHA

DMSO

EC

EC-OD

EDTA

$\mathrm{EEC}$ (=CEE)

FAO

$\mathrm{GC}$

GC-MS

GRAS

GSH

h

HMA

HPLC

ID

i. p.

i.v.

JECFA

Health

$k^{\prime}$

ke

LI

LOD acceptable daily intake

antipyrine

absorbance unit/arbitrary unit

area under the curve

absorbance unit full scale/arbitrary unit full scalle

6-tert-butyl-2,4-dimethylphenol

butylated hydroxyanisole

2-tert-butyl-4-hydroxyanisole

3-tert-butyl-4-hydroxyanisole

free (=unconjugated) $\mathrm{BHA}$

total (unconjugated and conjugated) $\mathrm{BHA}$

butylated hydroxytoluene

3,5-di-tert-butyl-4-hydroxybenzoic acid

5-bromo-deoxyuridine

chemical abstracts service registry number

Confederation des Industries Agro-Alimentaires de la CEE

plasma/saliva clearance

apparent plasma concentration at time zero

corn oil

coefficient of variation

day

dose

3,5-di-tert-butyl-4-thydroxyanisole

dimethylsulphoxide

ethoxycoumarin

ethoxycoumarin-O-deethylase

ethylene diamine tetraacetic acid

European Economic Community

Food and Agriculture Organization of the United Nations

gas chromatography

gas chromatograplyy-mass spectrometry

generally recognized as safe

glutathion

hour

3-hydroxymethylantipyrine

high-performance liquid chromatography

internal diameter

intraperitoneally

intravenously

Joint Food and Agriculture Organization of the United Nations/World

Organization Expert Committee on Food Additives

capacity factor

apparent first order elimination rate constant

labelling index

limit of detection 


$\begin{array}{ll}\text { MBHT } & \text { 3-mono-fert-butyl-4-hydroxytoluene } \\ \text { MHQ } & \text { tri-methyl-hydroquinone } \\ \text { min } & \text { minute } \\ \text { m } & \text { month } \\ \text { ND } & \text { not detectable } \\ \text { NEL } & \text { no-effect level } \\ \text { NORA } & \text { norantipyrine } \\ \text { ODS } & \text { octadecyl-silica } \\ \text { OHA } & \text { 4-hydroxyantipyrine } \\ \text { PB } & \text { phenobarbital } \\ \text { PBS } & \text { phosphate-buffered saline } \\ & \text { (0.01M phosphate buffer pH 7.4 in 0.9\% NaCl) } \\ \text { PC } & \text { paracetamol } \\ \text { PC-G } & \text { paracetamol-glucuronide } \\ \text { PC-S } & \text { paracetamol-sulphate } \\ \text { PFC } & \text { pair-fed control } \\ \text { PEG } & \text { polyethyleneglycol-400 } \\ \text { 15\% PEG } & \text { 15\% polyethyleneglycol-400 in water } \\ \text { p.O. } & \text { per os } \\ \text { RP } & \text { reversed-phase } \\ \text { RTED } & \text { range of tested effective doses } \\ \text { s.c. } & \text { sub-cutaneously } \\ \text { SD } & \text { salad dressing } \\ \text { S.D. } & \text { standard deviation } \\ \text { SE } & \text { standard error } \\ t 1 / 2 & \text { plasma/saliva elimination half life } \\ \text { TBQ } & \text { tert-butylquinone } \\ \text { TBHQ } & \text { tert-butylhydroquinone } \\ \text { free-TBHQ } & \text { free (=unconjugated) TBHQ } \\ \text { total-TBHQ } & \text { total (unconjugated and conjugated) TBHQ } \\ \text { Ts } & \text { mean transit time through the S-phase of cells } \\ \text { Tpot } & \text { potential doubling time } \\ \text { UDS } & \text { unscheduled DNA synthesis } \\ \text { UV } & \text { ultra-violet } \\ V \text { d } & \text { apparent volume of distribution } \\ \text { w } & \text { week } \\ \text { WHO } & \text { World Health Organization } \\ \text { yr } & \text { year } \\ & \end{array}$





\section{Chapter 1}

\section{General introduction}

\subsection{Toxicological risk assessment}

The development of chemical technology has enormously increased the availability of new chemicals like drugs, pesticides, plastics, etc...and several of them have been found to induce cancer development in man, like asbestos, vinyl chloride, acrylonitrile, 4aminobiphenyl, mustard gas and diethylstilbestrol (Hermo and Brandt-Rauf, 1987; Hermo, 1987). Human cancer incidence probably cannot be attributed to these new chemicals to a large extent, however. Doll and Peto (1981) estimated that the major causes of cancer in the USA are: tobacco, diet, infection and sex, accounting for $30 \%, 35 \%, 10 \%$ and $7 \%$ of all cancer deaths, respectively (Figure 1-1). In contrast, minor contributions to cancer development were ascribed to allcohol $(3 \%)$, occupation $(4 \%)$, pollution $(2 \%)$, industrial products $(<1 \%)$, geophysical factors $(3 \%)$, medicine $(1 \%)$ and food additives $(<1 \%)$. The possibly negative contribution of food additives $(-5$ to $+2 \%)$ to cancer prevalence was thought to arise from protective effects of food antioxidants and preservatives, like butylated hydroxyanisole (BHA) and butylated hydroxytoluene (BHT), the compounds studied in this thesis. The small contribution of food additives to cancer incidence will undoubtedly also result from the fact that food additives are among the chemicals most extensively tested for toxicity and carcinogenicity.

Tumor development following exposure to chemicals, is considered a biological process involving multiple steps: initiation and promotion, followed by progression (Hermo and Brandt-Rauf, 1987; Hermo, 1987; Harper and Legator, 1987; Kroes 1987). Some agents have only initiating or promoting potential, while others have both: "complete" carcinogens. In the mechanism of tumorigenicity, metabolism of a compound in the body towards a reactive ultimate carcinogen ("bioactivation"), may be a necessary step. Initiators are thought to operate stochastically, while for promotors a threshold, a no-effect level (NEL), is assumed to exist (Hogan and Hoel, 1982; Park and Snee, 1983; Brown, 1983; Kroes, 1987; Zeise et al., 1987).

Risk assessment encompasses three major steps: hazard identification, hazard evaluation and risk evaluation (Park and Snee, 1983). A risk evaluation is made to determine the probability whether and to what extent an identified potential hazard of a substance may actually be expressed in reality. Traditionally, risk assessment is divided into two methods: one for compounds that operate stochastically and one for agents that do not. Risk assessment for the second class of compounds, which comprises chemicals of which no carcinogenic effects are known and chemicals that are non-genotoxic carcinogens ("epigenetic" carcinogens, tumor-promotors and co-carcinogens), is based on the assumption that there is a dose at which there is not any effect observable. This dose, the NEL, established in experiments with laboratory animals, is assumed to be also the NEL in humans, and is converted into an acceptable daily intake (ADI) by dividing the NEL by a safety factor (e.g. 100) to correct for possible intra- and interspecies variation (Klaassen, 1986; Feron, 1987; 
Kotmam, 1983; Dutch Health Council, 1985; Kroes, 1987; Hogan and Hoel, 1982; Park and Snee, 1983). This conversion of a NEL in laboratory animals into a NEL in man is usually based on the concept of doses, expressed in $\mathrm{mg} / \mathrm{kg}$ body weight. Alternative approaches are based on doses expressed per body surface area or caloric intake (Dutch Health Council, 1985; Feron, 1987;. Hogan and Hoel, 1982). All approaches have in common that a dose is estimated which is assumed to have no effect in man. A major objection to these methods is that in general no data on (toxic) effects in humans are available to verify this extrapolation.

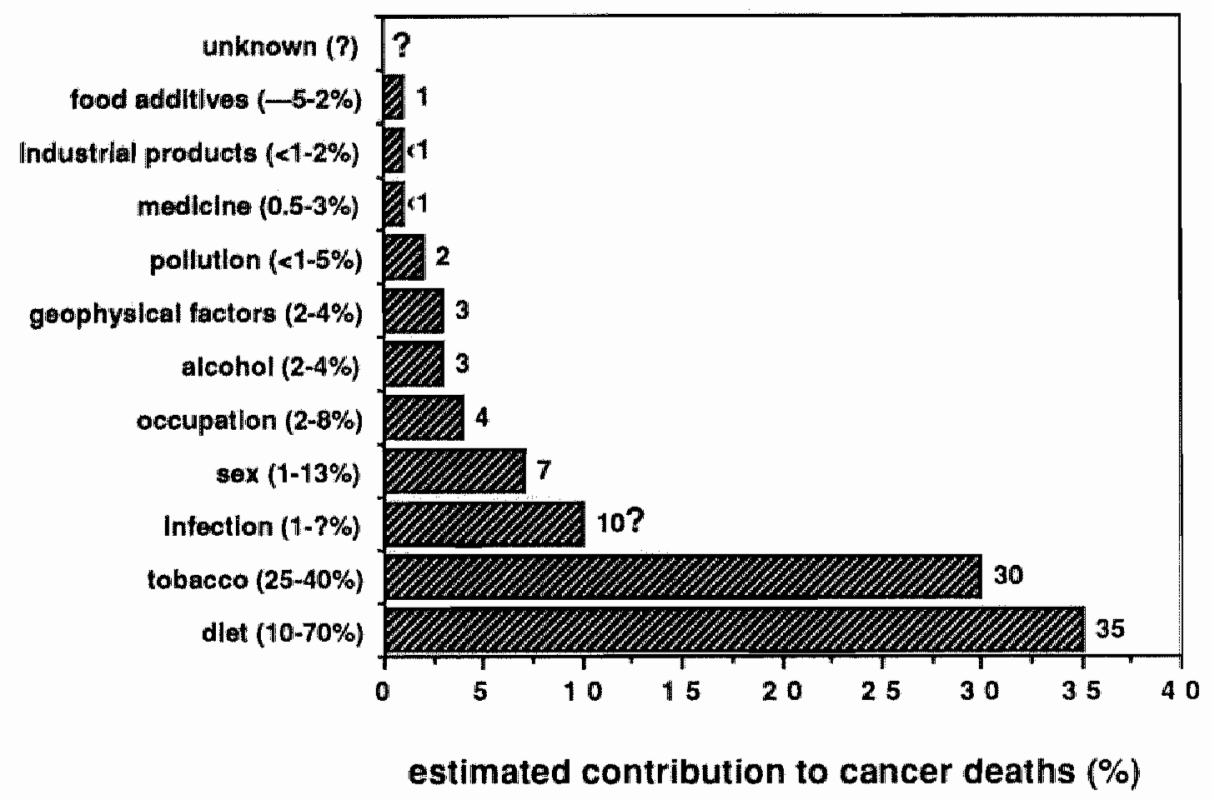

Figure 1-1: Estimated contribution of different causes ro cancer development based on Doll and Pero (1981). The contribution of food additives is less than $1 \%$. Values between brackets indicate the range of uncertainty of estimates.

An important part of differences in inter-species susceptibility to toxic substances results from differences in kinetics and metabolism (Dutch Health Council, 1985). Therefore, since different species dispose of chemicals in different ways, the concept of doses should be gradually replaced by the concept of concentrations (Garattini, 1986). In addition, the qualitative and quantitative determination of biotransformation pathways in animal v.s. man may recognize the possible in vivo formation of reactive metabolites (e.g. an ultimate toxicon or carcinogen) from the parent compound in either species. One of the difficulties in extrapolating such data from experimental animal to man is that generally kinetic parameters in man may be measured only in the blood, and not in the target tissue. However, a large part of the influence of toxicokinetics disappears by inter-species comparison on basis of attained concentration of an agent, or of its metabolites, in the circulation, whereas especially a toxicodynamic part remains (Dutch Health Council, 1985). This physiological approach, 
which requires the availability of data on kinetics and biotransformation in man, can only be performed for a limited number of compounds, to which man is intentionally exposed (e.g. drugs and food additives). Thus, an inter-species comparison of kinetics and metabolism may largely aid to a more sophisticated establishment of an ADI for human exposure to an agent.

The safety-factor approach cannot be applied to genotoxic carcinogens (e.g. those with a DNA-affecting potential) for there is basically no safe dose for this stochastically operating class of compounds - theoretically one molecule could induce a fatal hit. It is generally accepted that human exposure to genotoxic chemicals, for which a stochastical mechanism of action is assumed, should be avoided as much as possible, thus minimizing any theoretical risk for man. Various mathematical models have been developed to calculate the 'virtual safe dose' corresponding with a accepted maximal risk (e.g. 1 fatality in $1,000,000$ ), like the frequently used one-hit extrapolation (Hogan and Hoel, 1982; Park and Snee, 1983; Brown, 1983; Kroes, 1987; Zeise et al., 1987). It is a matter of judgement whether or not a certain risk is acceptable. Obviously food additives, to which man is intendedly exposed, cannot be permitted if they appear to be stochastically operating carcinogens. Consequently, all established ADI's for food additives have been calculated by the NEL-safety factor approach, and are based on the concept of doses $(\mathrm{mg} / \mathrm{kg}$ body weight).

Despite the relatively well-known toxicity profiles of food additives, occasionally new data become available questioning whether their application as food additives may still be considered safe for man. The sweetener sodium-saccharin, for instance, has been found to induce bladder tumors in rodents (Scientific Review Group, 1985). The synthetic food antioxidants butylated hydroxyanisole (BHA) and butylated hydroxytoluene (BHT) also are such rumourous compounds. Initially it was suggested that BHA and BHT could give rise to a reduction of cancer in man (Wattenberg, 1980, 1985, 1986; Hocman, 1988), but recently less favorable data on these compounds have come out. BHA is currently regarded as a complete carcinogen, with sufficient evidence of carcinogenicity, in rat and hamster forestomach (Anonymous, 1986 $\mathrm{b}$ ). For BHT there may be sufficient evidence of carcinogenicity as well in liver of rats and mice (Olsen et al., 1986; Würtzen and Olsen, 1986; Lindenschmidt et al., 1986; Inai et al., 1988).

In the next paragraphs background information is provided on lipid peroxidation and its prevention by antioxidants, as well as on the physico-chemical properties and toxicity profiles of BHA and BHT.

\subsection{General aspects of BHA AND BHT}

In this paragraph BHA and BHT are briefly introduced with respect to chemical structure, nomenclature, physico-chemical data, use and regulatory status (Anonymous, 1984, 1986 1986C; Sims and Fioriti, 1980; Windholz et al., 1983). 
*HA:
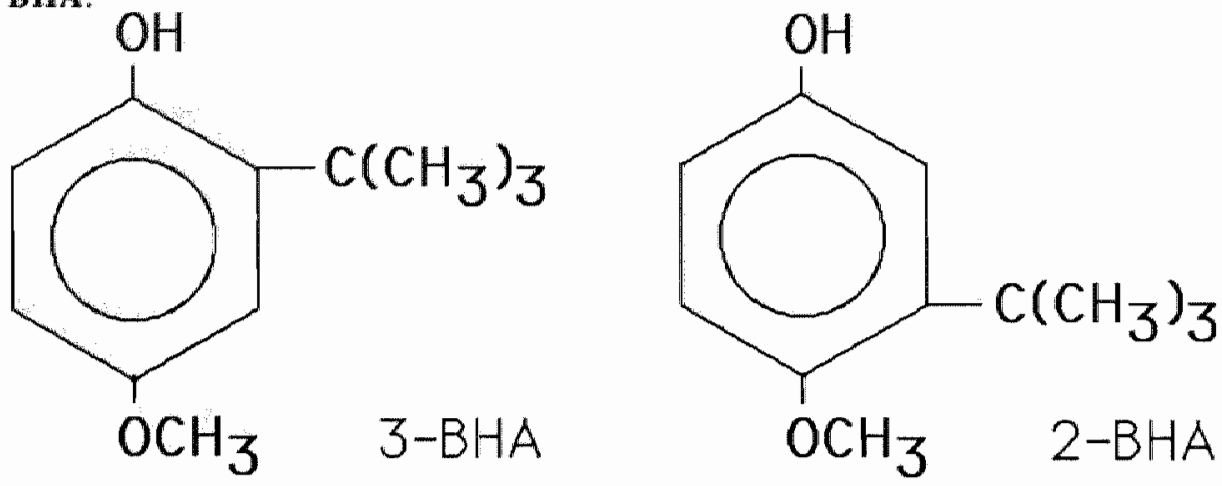

*nomenclature:

Chemical Abstract Service Reg. No. 25013-16-5

names:

butylated hydroxyanisole

(1,1-dimethylethyl)-4-methoxyphenol

tert-butyl-4-methoxyphenol

butyl hydroxyanisole

tert-butyl hydroxyanisole

tert-butyl-para-hydroxyanisole

tert-butyl-4-hydroxyanisole

2(3)-tert-butyl-4-hydroxyanisole

3(2)-tert-butyl-4-methoxyphenol

E 320

and numerous trade names

BHA is a mixture of 2-tert-butyl-4-hydroxyanisole ( $<15 \%$; CAS Reg. No:

121-00-6) and 3-tert-butyl-4-hydroxyanisole (>85\%; CAS Reg. No.: 88-32-4).

*chemical and physical data:

molecular weight:

melting point:

boiling point:

state:

solubility:

$180.25\left[\mathrm{C}_{11} \mathrm{H}_{16} \mathrm{O}_{2}\right]$

$48-55^{\circ} \mathrm{C}$

$264-270^{\circ} \mathrm{C}$

white or slightly yellow waxy solid

practically insoluble in water

soluble in many organic solvents

*use:

antioxidant in foods, cosmetics, food coating materials, waxes, vitamin A preparations, etc...

* regulatory status:

*Generally Recognized As Safe (GRAS) status (US Food and Drug Administration);

* temporary ADI of $30 \mathrm{mg}$ BHA/adult in EEC countries (Anonymous, 1987);

* temporary ADI of $0-0.5 \mathrm{mg} \mathrm{BHA} / \mathrm{kg}$ body weight (JECFA, 1989).

*permitted as a food additive in reportedly 50 countries. 
*BHT:

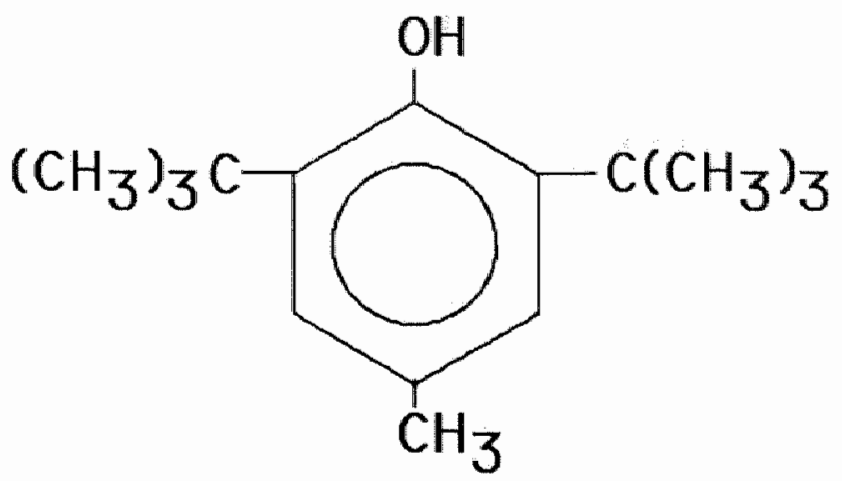

\section{*nomenclature:}

Chemical Abstract Service Reg. No: $128-37-0$

names:

butylated hydroxytoluene

2,6-bis(1,1-dimethylethyl)-4-methylphenol

2,6-di-tert-butyl-para-cresol

butyl hydroxytoluene

dibutylated hydroxytoluene

di-tert-butyl-para-cresol

ortho,ortho'di-tert-butyl-para-cresol

1,3-di-tert-butyl-2-hydroxy-5-

methylbenzene

3,5-di-tert-butyl-4-hydroxytoluene

2,6-di-tert-butyl-4-methylphenol

4-methyl-2,6-di-tert-butylphenol

dibunol

E 321

and numerous trade names

* chemical and physical data:

molecular weight:

melting point:

$220.36\left[\mathrm{C}_{15} \mathrm{H}_{24} \mathrm{O}\right]$

boiling point:

$70^{\circ} \mathrm{C}$

$265^{\circ} \mathrm{C}$

state:

white, crystalline solid

solubility:

practically insoluble in water

soluble in many organic solvents

*use:

antioxidant for food, animal feed, pharmaceuticals, food packaging materials, cosmetics, fat soluble vitamins, synthetic rubber, plastics, gasoline, diesel fuel, etc....

*regulatory status.

* GRAS status (US Food and Drug Administration);

* temporary ADI of $3 \mathrm{mg} \mathrm{BHT/adult} \mathrm{in} \mathrm{EEC}$ countries (Anonymous, 1987);

*temporary ADI of $0-0.125 \mathrm{mg}$ BHT/ $\mathrm{kg}$ body weight (JECFA, 1986 b); *permitted as a food additive in reportedly 40 countries. 


\subsection{Prevention of lipid peroxidation in foods by antioxidants}

Antioxidints are used to preserve oils, fats and shortenings from oxidative rancidity and the formation of potentially toxic degradation products and polymers (Sims and Fioriti, 1980; CIAA, 1985; Addis, 1986; Finley and Given, 1986; Anonymous, 1987). Although many food constituents may undergo oxidation, particularly those containing fats are susceptible to changes in collor, odor and taste. Especilally unsaturated fatty acids are readily involved in a process of peroxidation in the presence of molecular oxygen. Degradation products or formed polymers may elicit toxic reactions. Also in biological systems, the oxidation of lipids has profound consequences. For instance, peroxidative breakdown of polyunsaturated fatty acids is thought to be involved in tissue damage and the pathogenesis of haemolytic anaemia, as well as pulmonary and hepatic injury (Logani and Davies, 1980; Ames, 1983; Halliwell and Gutteridge, 1984; Sevenian and Hochstein, 1985; Anonymous, 1985; Vaca et al., 1988).

Initiation, propagation and termination processes of the self-catalyzed peroxidation chain reaction for lipids are generally presented as:

\begin{tabular}{|c|c|c|c|}
\hline \multirow[t]{2}{*}{ initiation: } & $\mathrm{RH}$ & 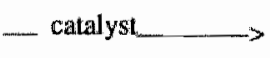 & $\mathrm{R} \cdot+\mathrm{H} \cdot$ \\
\hline & $\mathrm{RH}+\mathrm{O}_{2}$ & _ catalysi_ & $\mathrm{R} \cdot+\cdot \mathrm{OOH}$ \\
\hline \multirow[t]{2}{*}{ propagation: } & $\mathrm{R} \cdot+\mathrm{O}_{2}$ & $\longrightarrow$ & $\mathrm{ROO}$ \\
\hline & $\mathrm{ROO}+\mathrm{RH}$ & $\longrightarrow$ & $\mathrm{ROOH}+\mathrm{R}$ * \\
\hline \multirow[t]{2}{*}{ temination: } & $\mathrm{ROO}+\mathrm{ROO}$ & $>$ & $\mathrm{ROOR}+\mathrm{O}_{2}$ \\
\hline & $\begin{array}{l}\mathrm{ROO}+\mathrm{R} \\
\mathrm{R} \cdot+\mathrm{R} \cdot\end{array}$ & $\longrightarrow$ & $\begin{array}{l}\text { ROOR } \\
\text { RR }\end{array}$ \\
\hline
\end{tabular}

The initiation step, involves the creation of radicals. Hydrogen abstraction of the unsaturated lipid RH results in the formation of a lipid free radical R*, a process which is catalyzed by light, heat, traces of transition metals, and/or the presence of atmospheric oxygen. Radical formation can also take place by a metal-catalyzed decomposition of (hydro)peroxides. The carbon-centered radical tends to be stabilized by a molecular rearrangement to produce a conjugated diene, which in its turn readily reacts with the bi-radical molecular oxygen $\left(\mathrm{O}_{2}\right)$ to yield a lipidperoxide radical ROO. This is also capable of inducing the initiation by abstracting a hydrogen atom from another lipid molecule, thus leading to a propagation of the oxidation reaction. The termination reaction is typified by the combination of two radicals to yield non-radical molecules. Under normal conditions of oxygen tension the rearrangement of two $\mathrm{ROO}$ - lipidperoxides to $\mathrm{ROOR}$ and $\mathrm{O}_{2}$ is the most likely to occur. Lipid radicals can combine to form dimers, polymers, alcohols and peroxides. Alternatively, reactions with protein or nucleic acid constituents may occur leading to multiple reaction products (Finley and Given, 1986; Vaca et all., 1988).

Secondary products of lipid peroxidation resulting from the breakdown of lipid(hydro)peroxides involves the formation of aldehydes, ketones, alcohols, esters, and short-chain hydrocarbons (e.g. malondialdehydle, pentane, etc..), which impart unpleasant flavors and odors to rancid or reverted fats (CIAA, 1985; Addis, 1986; Frankel, 1987; Pincemail, 1987). Organoleptic deterioration ("rancidity") of fats presents a major problem to the food processing industry. Other objections to the presence of lipid autoxidation products are a decreased nutritional value by a destruction of essential food constituents 
(e.g. vitamin $A_{3}$ essential fatty acids). Moreover, ingested lipid peroxidation products may possess adverse health effects by disturbing membrane integrity or function as well as by forming secondary products with mutagenic potential (MacGregor et al., 1985; Anonymous, 1987; Hageman et al., 1988).

To be effective, antioxidants must be added to food materials of good quality. They will not protect or mask fat and shortenings that have already deteriorated. Basically, there are two types of antioxidants: radical scavengers and synergists (Sims and Fioriti, 1980; Anonymous, 1987). Radical scavengers, like the phenolic compounds BHA and BHT, interfere with the propagation step of the free radical chain reaction. Phenolic antioxidants (AH) may donate one hydrogen atom to the lipid radicals $\mathrm{R} \cdot \mathrm{RO}$. or $\mathrm{ROO}$, turning them into the more stable molecules $\mathrm{RH}, \mathrm{ROH}$ or $\mathrm{ROOH}$, thereby terminating the ongoing lipid autoxidation chain reaction:

$$
\begin{array}{lll}
\mathrm{AH}+\mathrm{R} \cdot & \longrightarrow \mathrm{A}+\mathrm{RH} \\
\mathrm{AH}+\mathrm{RO} \cdot & \longrightarrow \mathrm{A} \cdot+\mathrm{ROH} \\
\mathrm{AH}+\mathrm{ROO} \cdot \longrightarrow \mathrm{A} \cdot+\mathrm{ROOH}
\end{array}
$$

Antioxidant radicals themselves are converted into resonance-stabilized intermediates $A \cdot$, which is illustrated for BHA as follows (Sims and Fioniti, 1980):
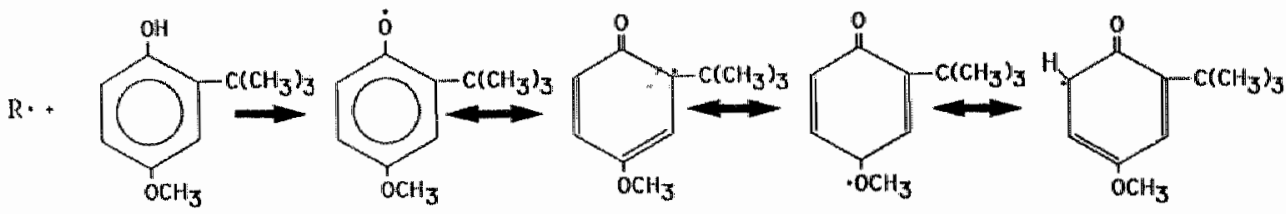

The resulting phenoxyl radical $A$ - may either be regenerated to the parent antioxidants molecule A by reducing species, or be further oxidized to a stable quinone, or may combine with other phenoxyl or lipid peroxyl radicals to give various non-radical molecules (CIAA. 1985; Warner et al., 1986 a $1986^{\mathrm{b}}$ ). Vegetable oils naturally contain phenolic antioxidants like tocopherols. Animal fats, in contrast, are relatively low in tocopherol content (CIAA, 1985) and, although they contain relatively little polyunsaturated lipids, these fats need the technological protection of added antioxidants like BHA and BHT. On the other hand, synthetic antioxidants are not very effective in preventing fats and oils of vegetable origin from oxidative deterioration.

Synergists may either regenerate parent antioxidant molecultes from phenoxyl radicals formed in the process of hydrogen atom donation, or act as a sequestering agent for transition metals, active catalysts in the initiation and propagation steps of lipid peroxidation. Frequently used radical scavengers are: tocopherols, gallate esters (propyl-, octyl- and dodecylgallate), ascorbic acid and its derivatives, BHA, BHT and tert-butylhydroquinone (TBHQ). Synergistically operaling antioxidants include: ascorbic acid and its derivatives, citric acid, ethylene diamine tetraacetic acid (EDTA). These antioxidants are not permitted for addition to foods in every country in the world, however (Sims and Fioriti, 1980). 


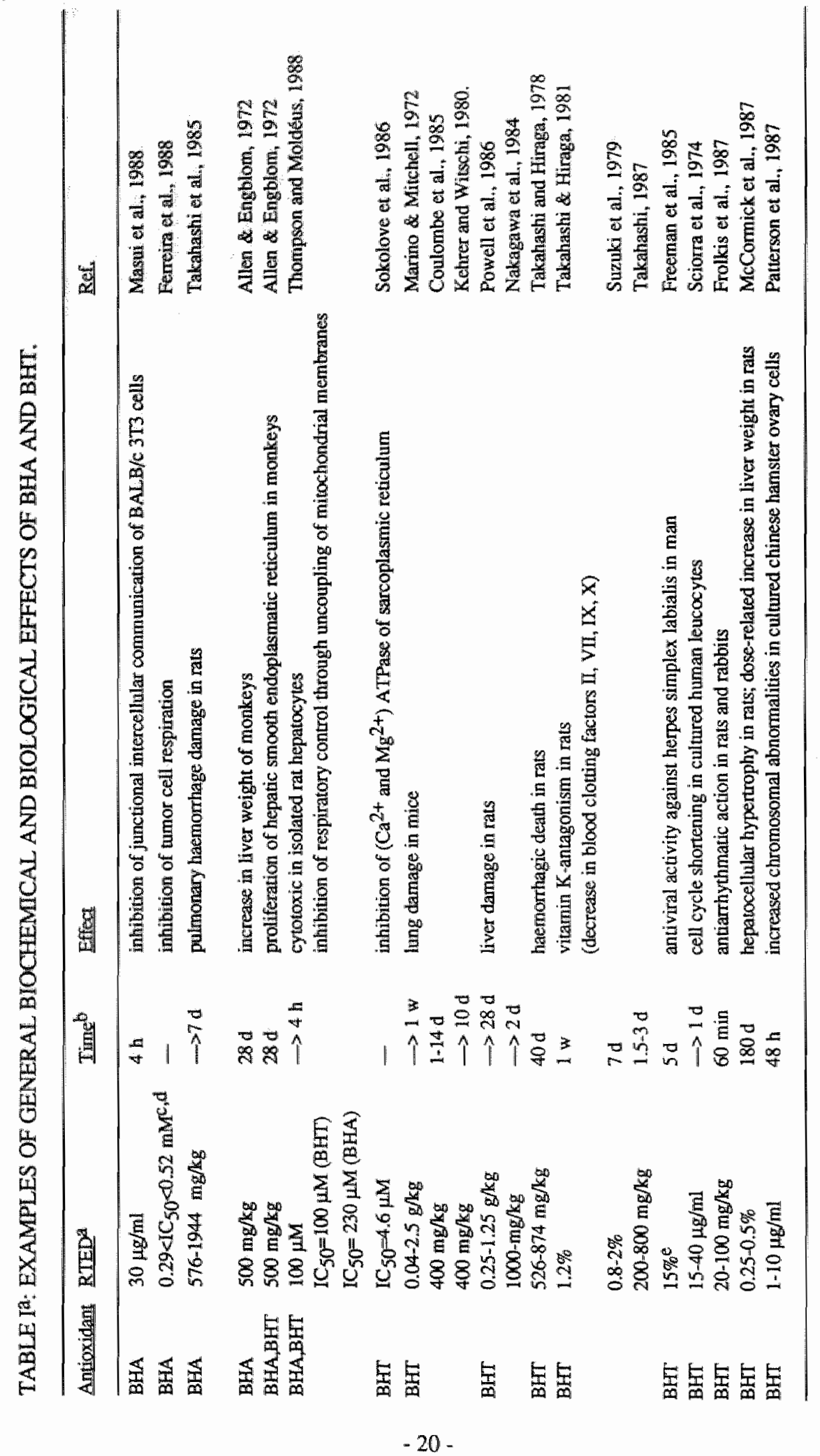




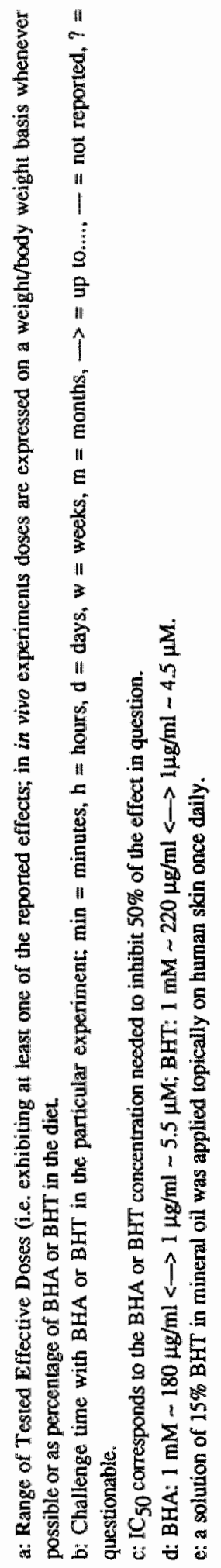


Legislation in the EEC, for example, does not allow the application of TBHQ (Haigh, 1986; Anonymous, 1987), while this phenolic compound is used on a large scale in the USA (Rebwoldt, 1986). Also inter-nation differences exist in permission for the use of certain antioxidants in particular food products. In the Netherlands, for instance, application of BHA and BHT is not allowed in margarine and butter.

A detailed survey of the world-wide use of antioxidants in foods as well as their permitted levels for use is beyond the scope of this introduction. Among foodstuffs that may contain added antioxidants are: vitamin preparations, flavours, essential oils, animal fats, butter fats,

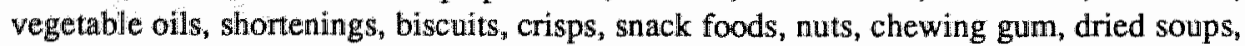
mayonnaise and emulsified sauces, salted margarine, potato-granules, -flakes and -powder, and others (Sims and Fioriti, 1980; CIAA, 1985; Rehwoldt, 1986; Anonymous, 1987).

\subsection{Toxicity of BHA and BHT}

Both BHA and BHT are compounds of relatively low acute toxicity. On the contrary, laymen as well as scientists ascribe beneficial actions to antioxidants, including BHT and BHA, which go far beyond their activity as reaction chain breakers in lipid peroxidation (Kahl, 1984). In this respect, life extension (Pearson and Shaw, 1982) and cancer prophylaxis (Wattenberg, 1980, 1985, 1986; Hocman, 1988) are the topics of major interest. Scientific literature on biochemical and biological actions of these compounds is vast and still growing enormously, and it is considered beyond the scope of this introduction to present all the data in detail. Numerous reviews have become available to cover this aspect sufficiently (Bramen, 1975; Wattenberg, 1980, 1985, 1986; Hocman, 1988; JECFA, 1986a, $1986^{\mathrm{b}}$; Anonymous, 1984, 1986 $\mathrm{b}, 1986^{\mathrm{c}}$; Ito, 1986; Ito et al., 1985, 1986 $\mathrm{a}$; Ito and Hirose, 1987; Kahl, 1984, 1986; Kitchin and Brown, 1987; De Long et al., 1983; Kleinjans et al., 1987; Babich, 1982; Malkinson, 1983; Witschi, 1986).

The effects of BHA and BHT can be divided into several classes: a) direct toxicity of BHA and BHT, including biochemical effects, for instance on enzyme activities; b) modulation of the toxicity (including mutagenicity and carcinogenicity) of other chemicals; c) carcinogenicity of $\mathrm{BHA}$ and $\mathrm{BHT}$ per se. Most data originate from experiments performed in vitro or in wivo using laboratory animals. There is a limited number of studies dealing with effects of BHA and BHT in man.

\subsection{Biological and biochemical actions}

Table 1-Ia gives an impression of the different levels of action of BHA and BHT. For BHT two profound toxic responses are known: lung toxicity in mice and witamin $\mathrm{K}$-antagonism, especially in rats, resulting in hemorrhage.

Table $1-\mathrm{I}^{\mathrm{b}}$ exemplifies the induction and inhibition of specific (biotransformation) enzymes by BHA and BHT. For example, BHT is a potent cytochrome P-450 inducing agent, and BHA readily induces glutathione $S$-transferases. Alterations of such metabolizing enzyme systems are, at least in part, supposed to participate in the modulation of the toxicity, mutagenicity and tumorigenicity of specific chemicals, in vitro as well as in vivo (Table 1Ic). Enhancing or inhibitory effects may depend on dose and time schedule of antioxidant administration and on the compound being studied. As mentioned above, prophylaxis of 


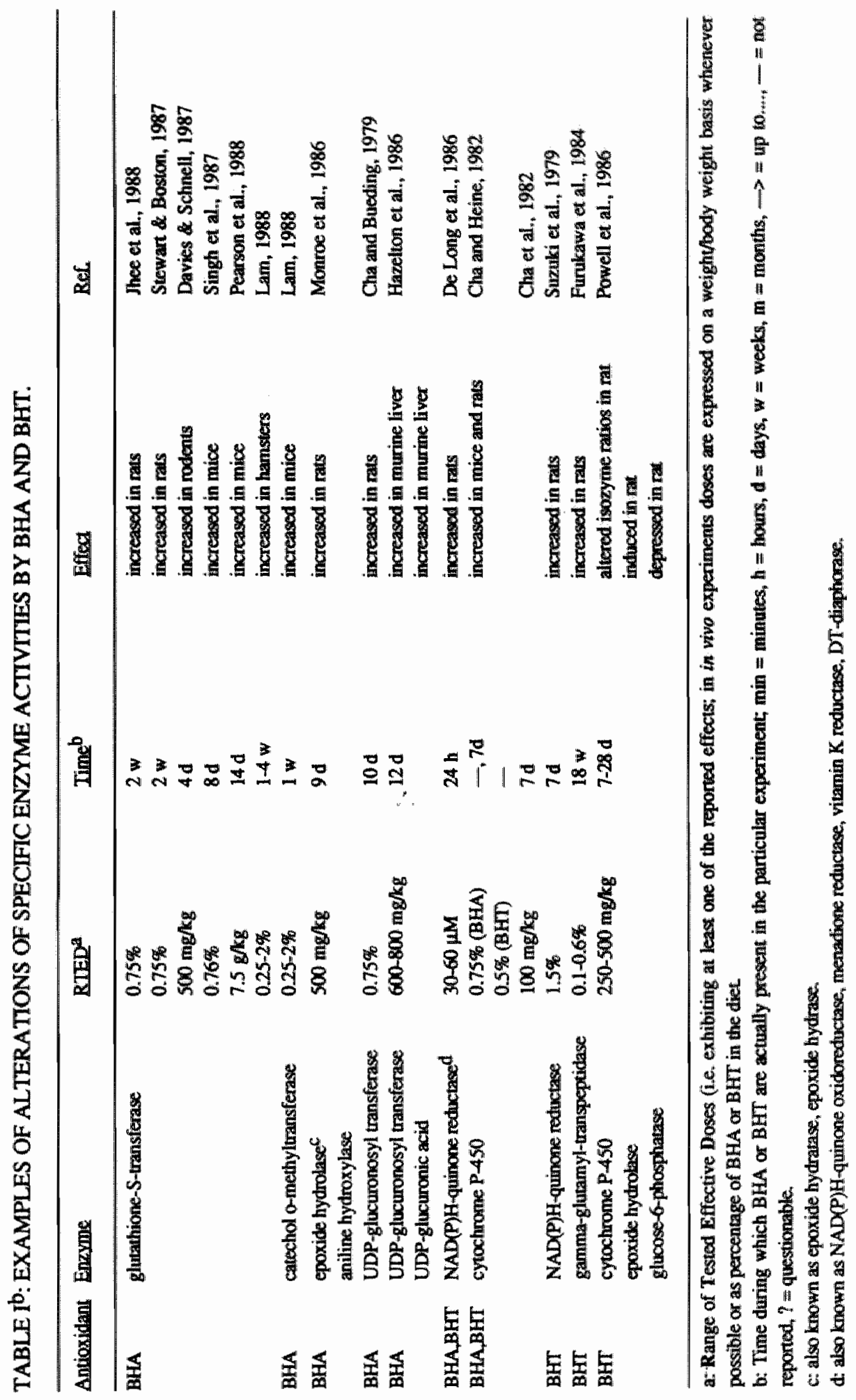




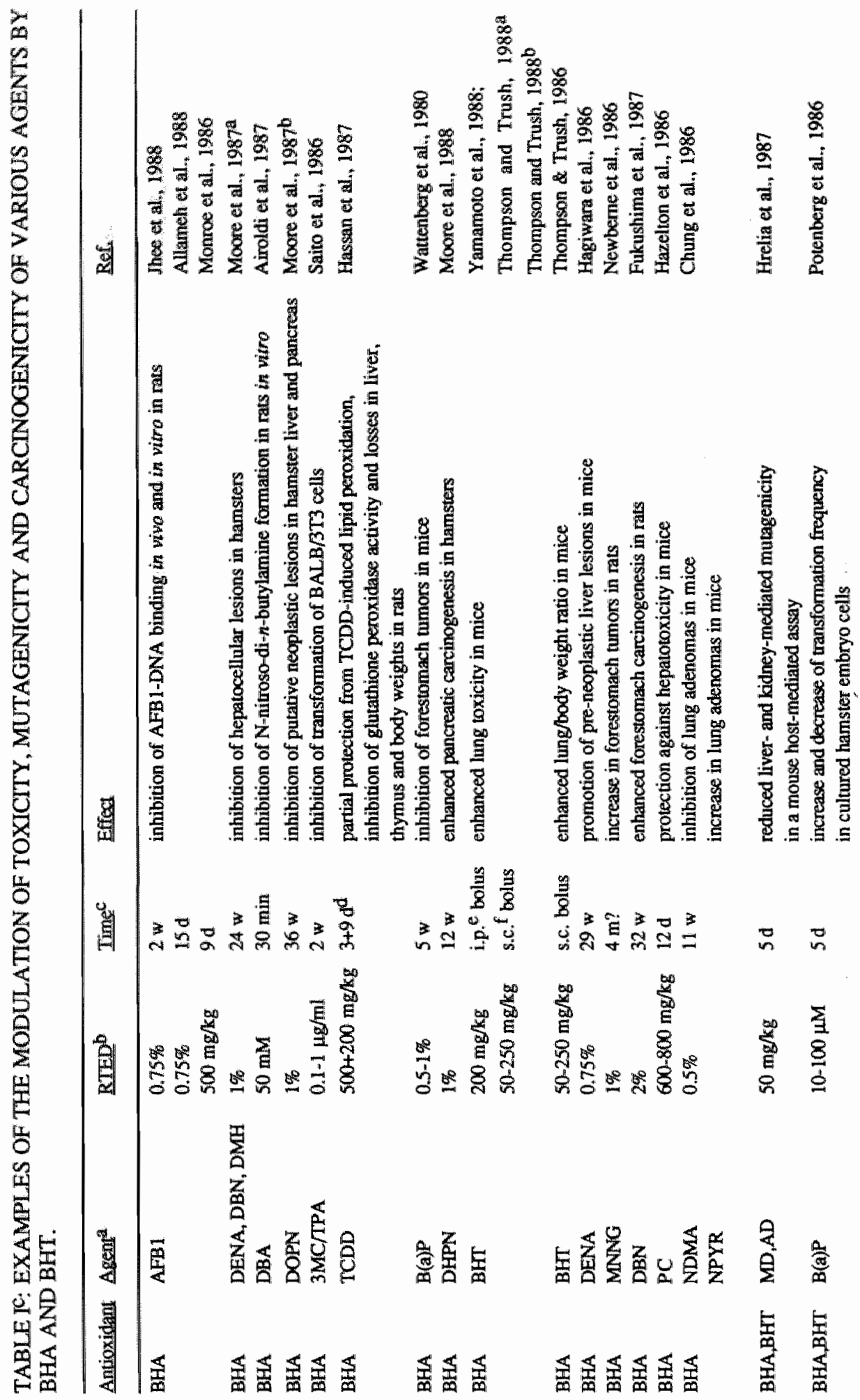




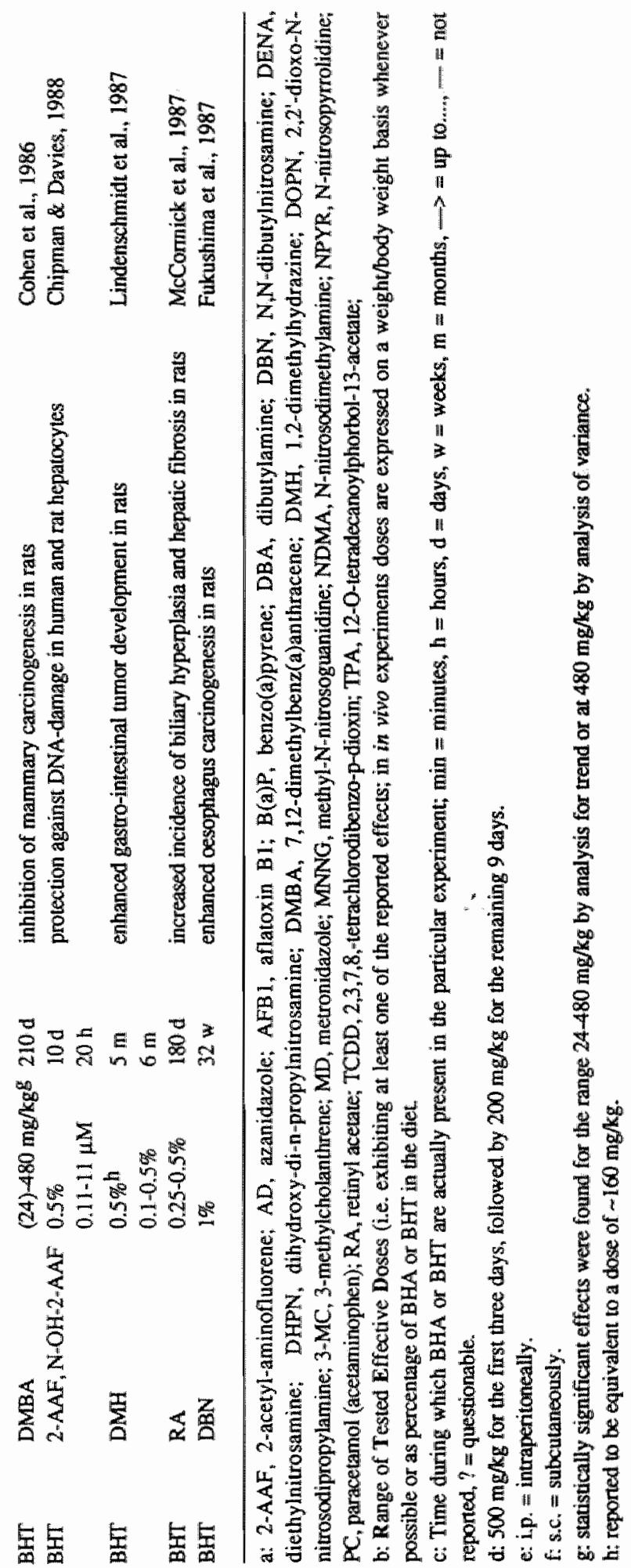


carcinogenicity by these phenolic antioxidants has been the reason for the profound interest in their (partially) chemopreventive behavior (Wattenberg, 1980, 1985, 1986; Hocman, 1988) as well as their possible negative contribution to human cancer development in the study by Doll and Peto (1981).

\subsection{Carcinogenicity of $\mathrm{BHA}$ and $\mathrm{BHT}$ in animals}

Apart from their potential to modify chemical carcinogenesis, there has been provided sufficient evidence ${ }^{\mathrm{l}}$ for the carcinogenicity of BHA and limited evidence for the carcinogenicity of BHT in experimental animals (Anonymous, 1986 b, 1986 ${ }^{\mathrm{c}}$ ). Based on novel data (Olsen et al., 1986; Würtzen and Olsen, 1986; Lindenschmidt et al., 1986; Inai et al., 1988) for BHT there may be reason to classify this agent as sufficient evidence for carcinogenicity in experimental animals, however. It should therefore be assumed that "In the absence of data on humans, it is reasonable, for practical purposes, to regard chemicals or exposures for which there is sufficient evidence of carcinogenicity in animals as if they presented a carcinogenic risk to humans" (Anonymous, 1986 b). Further, it has been reported that for BHA and BHT there is no evidence ${ }^{2}$ and inadequate evidence, respectively, for genetic activity in short-term tests; no data on cell transformation are available (Anonymous, $1986^{\mathrm{b}}, 1986^{\mathrm{c}}$ ).

Evaluation of carcinogenicity studies in experimental animals (Anonymous 1986a):

"'[1] Sufficient evidence of carcinogenicity is provided when there is an increased incidence of malignant tumours: [a] in multiple species or strains; or [b] in multiple experiments (preferably with different routes of administration or using different dose levels); or [c] to an unusual degree with regard to incidence, site or type of turnour, or age at onset. Additional evidence may be provided by data on dose-response effects.

[2] Limited evidence of carcinogenicity is available when the data suggest a carcinogenic effect but are limited because: [a] the studies involve a single species, strain or experiment; or [b] the experiments are restricted by inadequate dosage levels, inadequate duration of exposure to the agent, inadequate period of follow-up, poor survival, too few animals, or inadequate reporting; or [c] the neoplasms produced often $0 c c u r$ spontaneously and, in the past, hawe been difficult to classify as malignant by histological criteria alone (e.g. lung adenomas and adenocarcinomas and liver tumours in certain strains of mice).

[3] Imodequate evidence of carcinogenicity is available when, because of major qualitative or quantitative litmitations, the studies canmot be interpreted as showing either the presence or absence of a carcinogenic ellect.

[4] No evidence of carcinogenicity applies when several adequate studies are available which show that, within the limits of the tests used, the chemical or complex mixture is not carcinogenic.

It should be noted that the categories sufficient evidence and limited evidence refer only to the strength of the experimental evidence that these chemicals or complex mixtures are carcinogenic and not to the extent of their carcinogenic activity nor to the mechanism involved. The classification of any chemical may change as new information becomes available."

${ }^{2}$ Evaluation of genetic activity in short-term tests (Anonymous 1986a):

"[1] Sufficient evidence is provided by at least three positive entries, one of which must involve mammalian cells in vitro or in viwo and which must include at least two of threc end-points - DNA damage, mutation and chromosomal effects.

[2] Limited evidence is provided by at least two positive entries.

[3] Inadequate evidence is available when there is only one positive entry or when there are too few data to permit an evaluation of an absence of genetic activity or when there are unexplained, inconsistent findings in different test systems.

[4] No evidence applies when there are only negative entries; these must include entries for at least two endpoints and two lewels of biological complexity, one of which must involve mammalian cells in wirro or in wivo.

It is emphasized that the abowe definitions are operational, and that the assignment of a chemical or complex mixture into one of these categories is thus arbitrary." 
The target tissue for carcinogenicity of BHA is the forestomach in rodents. In non-rodents the oesophagus is prone to effects of BHA in some instances. The target tissue for carcinogenicity of BHT in rodents is the liver and perhaps also the lung. Tables 1 - II ${ }^{a}$ and 1II $^{\mathrm{b}}$ summarize the tumorigenicity and tumorigenicity-related effects of BHA and BHT in rodents, and include some important findings in non-rodents within this respect.

As a consequence of their negative responses in short-term tests for genotoxicity, BHA and BHT are considered to be non-genotoxic (so-called "epigenetic") carcinogens. Although the mechanism underlying their tumorigenicity is not known, BHA and BHT are assumed to be non-stochastically operating carcinogens. Hence, an ADI for BHA and BHT is calculated by the NEL-safety factor approach.

\subsection{Data on BHA and BHT in man}

There are few human data on BHA and BHT. The majority of data concerns the fate of BHA and BHT in man. Metabolism and kinetics of BHA and BHT will be described in detail elsewhere in this thesis, however, and have been reviewed in the past (Branen, 1975; Babich, 1982; Malkinson, 1983; Anonymous, 1984, 1986 b 1986c; Conning and Phillips, 1986). In short, the predominant metabolic pathway for BHA in all species studied, including man, is conjugation of the phenolic hydroxylgroup with glucuronic acid and sulphate. O-demethylation of BHA towards TBHQ, followed by conjugation with glucuronic acid and sulphate has been reported to occur in several species, including man. In animals, for BHT the principal metabolic pathway involves oxidation of the paramethylgroup leading to 3,5-di-tert-butyl-4-hydroxybenzoic acid, either free or conjugated with glucuronic acid. In man, however, the major metabolite of BHT is the glucuronic acid conjugate of 5-carboxy-7-(1-carboxy-1-methylethyl)-3,3-dimethyl-2-hydroxy-2,3dihydrobenzofuran.

Some effects of BHA and BHT in man have been reported. BHA as well as BHT, either as an ingredient of foodstuffs or cosmetics, may lead to allergic reactions (Fischerman and Cohen, 1973; Roed-Petersen and Hjorth, 1976; Fischer, 1976; White et al., 1984; Young et al., 1987; ). BHT was successfully used for the treatment of recurrent herpes simplex labialis by topical application of $15 \%$ BHT in mineral oil (Freeman et al., 1985) although it has not been approved as a drug by the U.S. Food and Drug Administration (Shlian and Goldstone, 1986). In contrast, ingestion of $4 \mathrm{~g} \mathrm{BHT}$ by a female suffering from herpes simplex virus-2 led to the development of gastritis (Shlian and Goldstone). There are no data on the carcinogenicity of BHA or BHT in man (Anonymous, $1986^{\mathrm{b}}, 1986^{\mathrm{C}}$ ),

\subsection{The present ADI's for BHA and BHT}

For the time being, BHA and BHT, although complete carcinogens, are assumed to possess no genotoxic activity, due to absence of positive responses in short-term tests for genotoxicity (Anonymous, 1986b, 1986 c). Consequently, the establishment of an ADI for these "epigenetic" carcinogenic food additives is performed by the NEL-safety factor approach, based on a dose/body weight comparison. For BHA the current ADI (0-0.5 $\mathrm{mg} / \mathrm{kg}$ body weight) is based on tumorigenicity-related findings for which an apparent NEL was found at $62.5 \mathrm{mg} / \mathrm{kg}$ body weight in rats (JECFA, 1986a ; JECFA, 1988; Anonymous, 1987; Haigh, 1986). According to the FAONWHO, for BHT the current ADI is 0-0.125 


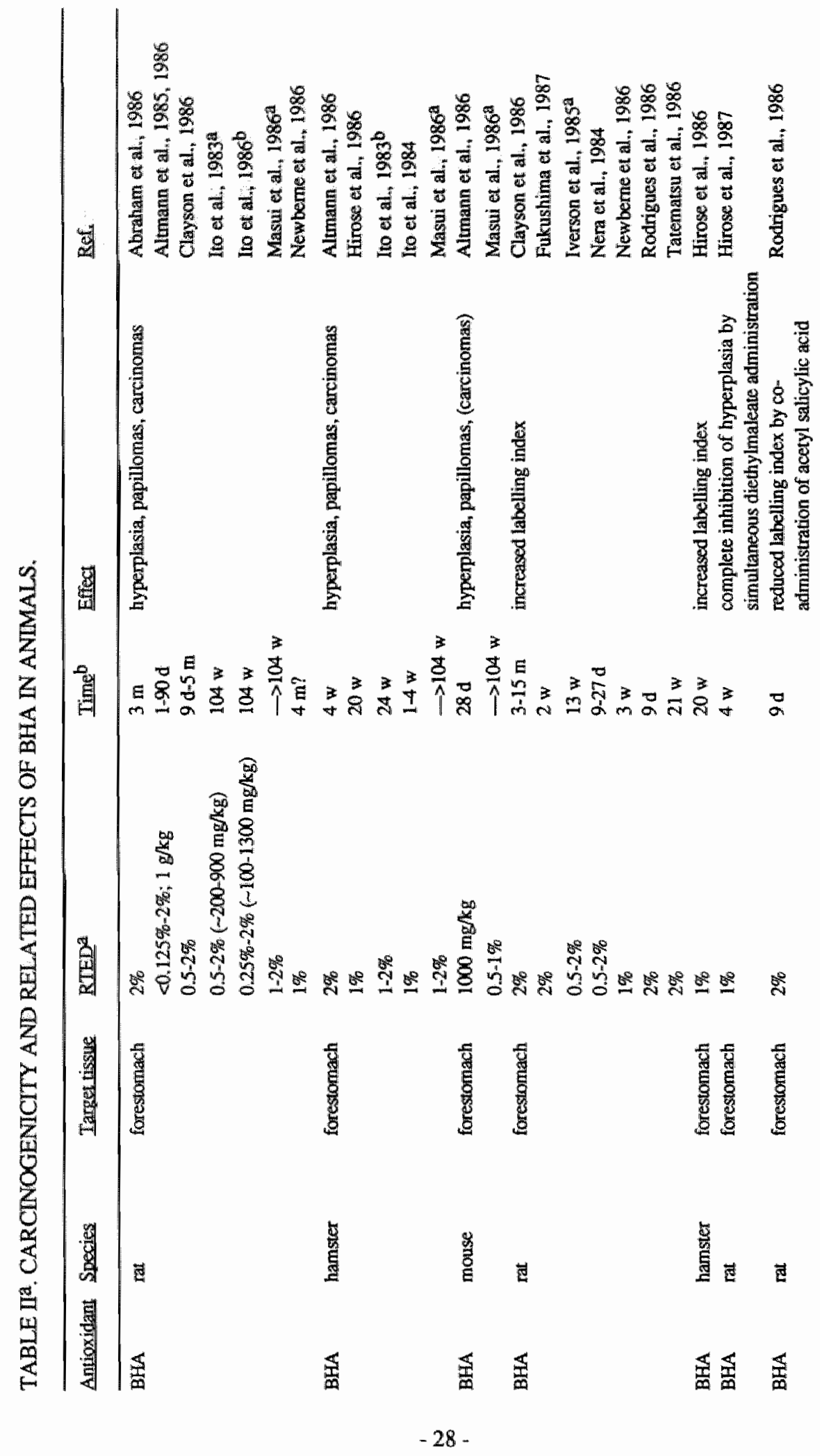




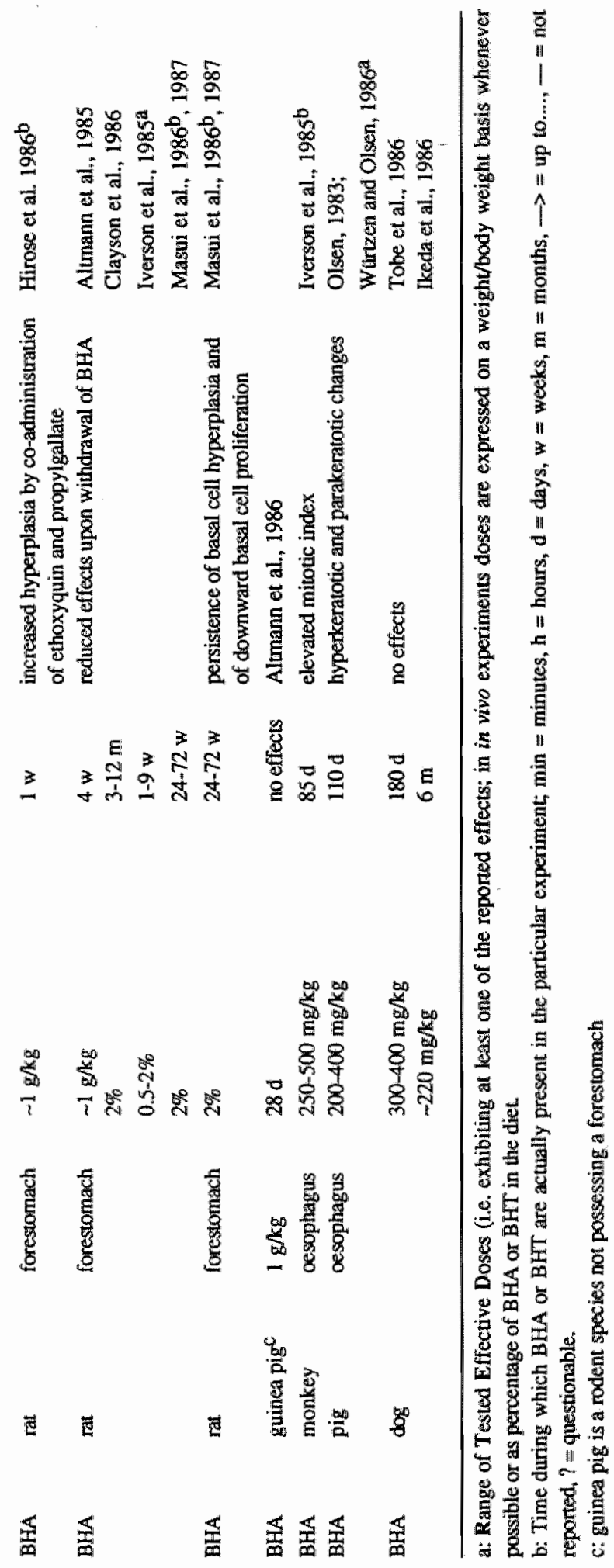




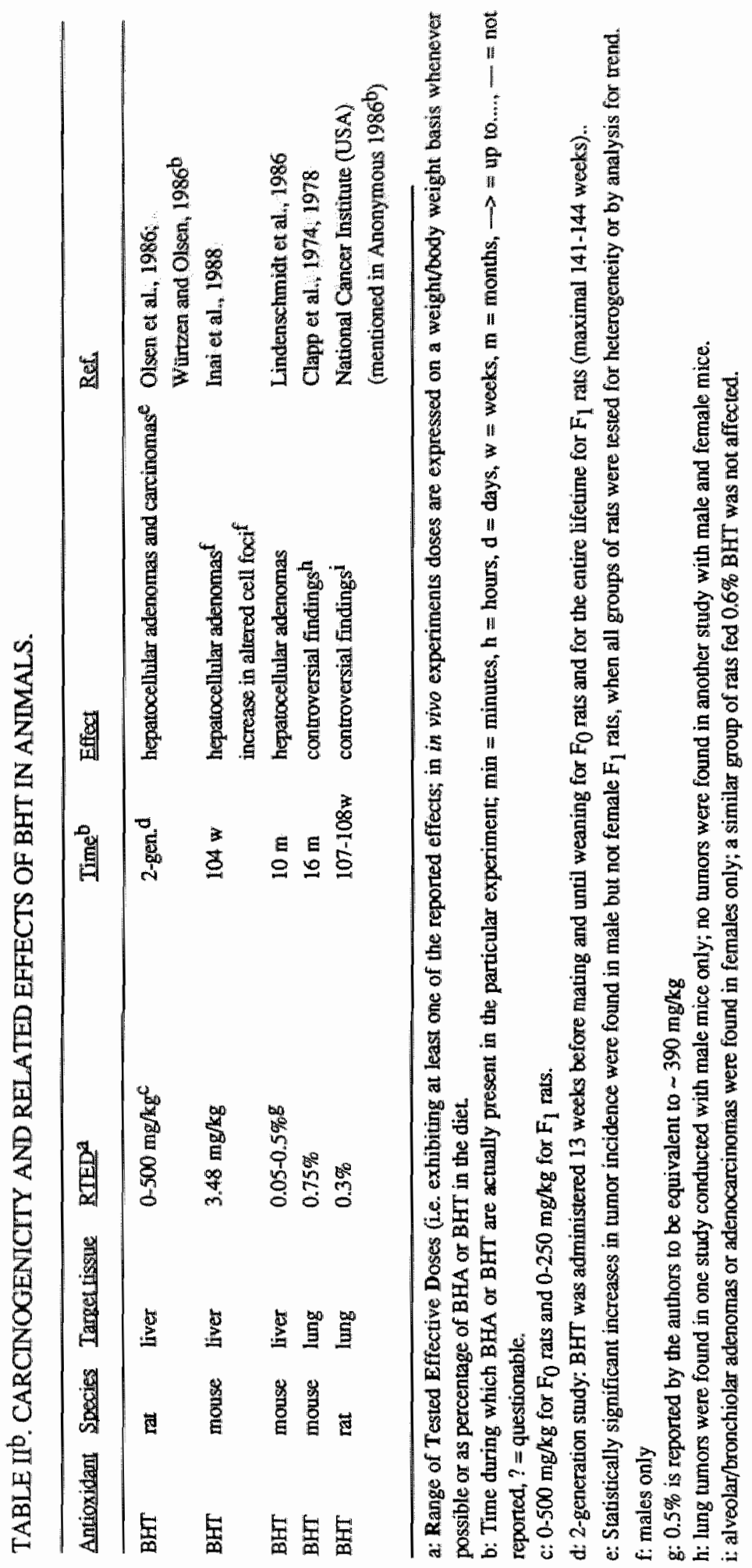


$\mathrm{mg} / \mathrm{kg}$ body weight based on a reproduction study (NEL $=25 \mathrm{mg} / \mathrm{kg}$ body weight ${ }_{*}^{-}$JECFA, $1986^{b}$ ). According to the EEC the current ADI for BHT is only $0-0.05 \mathrm{mg} / \mathrm{kg}$ body weight based on reproduction, thyroid and hematological effects in the rat (NEL $\pm 5 \mathrm{mg} / \mathrm{kg}$ body weight; Anonymous, 1987; Haigh, 1986).

\subsection{Aim of the thesis}

The current ADI's for BHA and BHT are still based on insufficient experimental data. This thesis sets out to achieve a well founded basis for the assessment of potential health risks associated with human exposure to BHA and BHT. Therefore information is required on the mechanism underlying the tumorigenicity of BHA and BHT in experimental animals, which is of utmost importance for the choice of the risk extrapolation model. This is one of the intentions of this thesis. If BHA and BHT turn out to possess genotoxic potential, they will no longer be acceptable as food additives in the human diet. Furthermore, the identification of hazardous effects of BHA on digestive tract tissues other than the forestomach in laboratory animals, is a second intention of this thesis, contributing to the evaluation of potential health hazards associated with dietary BHA intake by man, who does not possess a forestomach.

As mentioned in paragraph 1.1, a comparison of kinetics and metabolism in man vs. rat may largelly aid to a more sophisticated risk assessment. It is well possible to perform experiments with food additives, like BHA and BHT, with respect to their disposition in man and animal. Therefore, a comparison of the fate of BHA and BHT in man vs. rat, a susceptible species for the toxic and carcinogenic effects of these food antioxidants, is another intention of the study presented in this thesis. In order to provide a more physiological basis for the assessment of potential health risks associated with human dietary intake of the carcinogenic food additives BHA and BHT, emphasis will be laid on the concept of doses vs. the concept of concentrations in the blood and tissues, and on the recognition of bioactivation pathways in vivo.

Since a hazard is not a risk to humans until there is exposure to an agent (Park and Snee, 1983), it is also intended in this thesis to estimate the actual daily consumption of BHA and BHT by man.

Resuming, this thesis sets out to increase information on the biological fate of BHA and BHT in man, on the mechanism of tumorigenicity of BHA and BHT, on the recognition of potential target tissues for BHA other than the forestomach, and on the actual daily BHA and BHT consumption by man in order to provide a better basis for the assessment of potential health risks associated with dietary intake of BHA and BHT by man.

\subsection{Outline of the thesis}

In part I several methods are described for the chemical analysis of BHA and BHT. Methods for the determination of BHA and BHT in plasma are reported in chapters 2 and 3 , respectively. In addition, a method has been presented for the rapid determination of the ratio of the 2- and 3-isomers of BHA in a batch (chapter 4). All presented methods apply high-performance liquid chromatography.

Part II deals with the fate of BHA and BHT in man and rat. Both toxicokinetics and 


\section{chapter I}

biotransformation have been investigated. In chapter 5 the disposition of single oral doses of BHA in man and rat are compared, following administration of $0.5 \mathrm{mg} B \mathrm{BA} / \mathrm{kg}$ body weight to male wolunteers and $2-200 \mathrm{mg} / \mathrm{kg}$ bodly weight to male Wistar rats. Chapter 6 reports on the excretion of $\mathrm{BHA}$ and its metabolites into the bile of male Wistar rats, following a single oral dose of $200 \mathrm{mg}$ BHA/kg body weight. In chapter 7 the disposition of a single oral dose of BHT in male volunteers $(0.5 \mathrm{mg} / \mathrm{kg}$ body weight) and male Wistar rats (20-200 $\mathrm{mg} / \mathrm{kg}$ body weight) is compared.

Part III consists of one study in which the present ADI for BHA ( $0.5 \mathrm{mg} / \mathrm{kg}$ body weight) is ingested daily as a single oral dose by eight male volunteers for ten consecutive days (chapter 8). This study was initiated by the results of the experiments described in chapter 5 . Standard clinical parameters and phase-I and -II biotransformation capacity were monitored before and during the period of BHA administration. In addition, the fate of BHA was monitored on several days during BHA intake.

Part IV consists of four chapters describing experiments intended to unravel the unknown mechanism of the carcinogenicity of BHA (and BHT). Mutagenic potential of BHA and BHT has been studied in the Salmonella/microsome assay using new tester strains (chapter 9). The susceptibility of the forestomach and other tissues of the gastro-intestinal tract to the proliferative effects of BHA has been investigated in rat, for which purpose a new technique was applied. Proliferative effects of $\mathrm{BHA}$ were regarded as markers of the carcinogenic potential of BHA and were determined by assessing the labelling index and other cell kinetic parameters by flow cytometry and immunocytochemistry following two weeks of administration of $2 \%$ BHA in the diet of male Wistar rats (chapters 10 and 12). The involvement of oxidative cytochrome P-450-mediated O-demethylation of BHA into TBHQ in the mechanism underlying proliferative responses of BHA in rat forestomach, was investigated in order to determine whether this biotransformation pathway could be responsible for its carcinogenic behavior in rats (chapter 11). In chapter 12 the dosedependency of effects of BHA on cell kinetic parameters in the forestomach of male Wistar rats is reported in order to establish a NEL for these effects. In addition, the effect of a reduction in caloric intake as a result of non-palatability of diets containing $2 \%$ BHA on cell kinetic parameters in gastro-intestinal tract tissues of male Wistar rats was investigated.

In part $\mathrm{V}$ the daily intake of BHA and BHT from the diet by man in the Netherlands has been estimated, based on a recently published dietary record survey, representative for the Dutch population of $0-75$ years old (chapter 13 ).

In chapter 14 the outcome of the studies is discussed and suggestions for future research are given. 


\section{References}

- R. Abraham, K.F. Benitz, G. Patil and R, Lyon (1986), Rapid induction of forestonach timors in partially hepatectomized Wistar rats given butylated hydroxyanisole. Exp. Molec. Pattiol. 44: 14:20.

- P.B. Addis (1986). Occurrence of lipid oxidation products in foods. Food Chem. Toxicol. 24: 10211030.

- L. Airoldi, R. Pastorelli, A. Macri, M. Bonfanti and R. Fanelli (1987). Effect of butylatod hydroxyanisole on in vitro and in wivo nitrosation of dibutylamine. Toxicology 43: 217-225.

- A. Allameh, M. Saxena and H.G. Raj (1988). Differential effects of butylated hydroxyanisole on metabollism of aflatoxin B1 in vitro by liver and lung microsomes. Cancer Letl. 40: 49-57.

- J.R. Allen and J.F. Engblom (1972). Ultrastructural and biochemical changes in the liwer of monkeys given butylated lyydroxytoluene and butylated hydroxyanisole. Food Cosmet. Toxicol. 10: 769-779.

- H-J. Altmann, P.W. Wester, G. Matthiaschk, W. Grunow and C.A. van der Heyden (1985), Induction of carly lesions in the forestomach of rats by 3-tert-butyl-4-hydroxyanisole (BHA). Food Chem. Toxicol. 23: 723-731.

- H-J. Altmann, W. Grunow, U. Mohr, H.B. Richter-Reichhelm and P.W. Wester (1986). Eiffects of BHA and related phenols on the forestomach of rats. Food Chem. Toxicol. 24: 1183-1188.

- B.N. Ames (1983). Dietary carcinogens and anticarcinogens. Oxygen radicals and degeneratiwe discascs Science 221: 1256-1264.

- Anonymous (1984). Final report on the safety assessment of butylated ligydroxyanisole. J. Amer. Coll. Toxicoll. 3: 83-146.

- Anonymous (1985). Lipid peroxidation: a radical chain reaction. in: Free radicals in biology and medicine. (B. Halliwell and J.M.C. Gutteridge, Eds.), Clanendon Press, Oxford, England, p139-189.

- Anonymous (1986a). Preamble. IARC Monographs on the evaluation of the carcinogenic risk of chemicals to humans. $40: 13-32$.

- Anonymous (1986) ). Butylated hydroxyanisole (BHA). IARC Monographs on the evaluation of the carcinogenic risk of chemicals to humans. 40:123-159.

- Anonymous $\left(1986^{\mathrm{C}}\right.$ ). Butylated hydroxytoluene (BHT). IARC Monographs on the evaluation of the carcinogenic risk of chemicals to humans. 40:161-206.

- Anonymous (1987). Commission of the European Communities. Report of the Scientific Committce for Food on antioxidants. CS/ANT/20-Final.

- H. Babich (1982). Butylated hydroxytoluene (BHT); a review. Environ. Res. 29: 1-29.

- A.L. Branen (1975). Toxicology and biochemistry of butylated hydroxyanisole and butylated hydroxytoluene. J. Am. Oil Chem. Soc. 52: 59-63.

- C.C. Brown (1983). Learning about toxicity in humans from studies on animals. Chemtech june: 350 358.

- Y.N. Cha and E. Bueding (1979). Effect of 2(3)-tert-butyl-4-hydroxyanisole administration on the activities of several hepatic microsomal and cytoplasmic enzymes in mice. Biochem. Pharmacol. 28: $1917-1921$.

- Y.N. Cha and H.S. Heine (1982). Comparative effects of dietary administration of 2(3)-ter-butyl-4hydroxyanisole and 3,5-di-tert-butyl-4-hydroxytoluene on several hepatic enzyme activities in mice and rats. Cancer Res. 42: 2609-2615.

- Y.N. Cha, H.S. Heine and P. Moldeus (1982). Differential effects of dietary and intraperitoneal administration of antioxidants on the activities of several hepatic enzymes of micc. Drug Metab. Disp. 10: $434-435$

- J.K. Chipman and J.E. Davies (1988). Reduction of 2-acetylaminofluorene-induced unscheduled DNA synthesis in human and rat hepatocytes by butylated hydroxytoluene. Mut. Res. 207: 193-198.

- F-L. Chung, M. Wang. S.G. Carmella and S.S. Hecht (1986). EfTects of butylated hydroxyanisole on the tumorigenicity and metabolism of $\mathrm{N}$-nitrosodimethylamine and $\mathrm{N}$-nitrosopyrrolidine in $\mathrm{A} / \mathrm{J}$ micc. Cancer Res. 46: 165-168.

- CIAA (Confederation des Industries Agro-Alimentaires de la CEE) (1985). Antioxidants. A dossier prepared by the CIAA for submission to the EEC Scientific Committee for Food. ADD-8/85-Final.

- N.K. Clapp. R.L. Tyndall, R.B. Cumming and J.A. Otten (1974). Effects of butylated hydroxytoluene alone or with diethylnitrosamine in mice. Food Cosmet. Toxicol. 12: 367-371. 
- N.K. Clapp, R.L. Tyndall, L.C. Satterfield, W.C. Klima and N.D. Bowles (1978). Selective sex-related modification of diethylnitrosamine-induced carcinogenesis in BALB/c mice by concomitant. administration of butylated hydroxytoluene. J. Natl. Cancer Inst. 61: 177-182.

- D.B. Clayson, F. Iverson, E. Nera, E. Lok, C. Rogers, C. Rodrigues, D. Page and K. Karpinski (1986). Histopathological and autoradiographical stidlies on the forestomach of F344 rats treated with butylated hydroxyanisole and related chemicals. Food Chem. Toxicol. 24: 1171-1182.

- L.A. Cohen, K. Choi, S. Numoto, M. Reddy, B. Berke and J.H. Weisburger (1986). Inhibition of chemically induced mammary carcinogenesis in rats by long-term exposure to butylated hydroxytoluene (BHT): interrelations among BHT concentration, carcinogen dose, and diet. J. Nat1. Cancer Inst. 76: $721-730$.

- D.M. Conning and J.C. Phillips (1986). Comparative metabolism of BHA, BHT and other phenolic antioxidants and its toxicological relevance. Food Chem. Toxicol. 24: 1145-1148.

- D.L. McCormick, T.A. Hultin and CJ. Detrisac (1987). Potentation of vitamin A hepatotoxicity by butylated hydroxytoluene. Toxicol. Appll. Pharmacoll. 90: 1-9.

- P.A. Coulombe, P.R. Filion and M.G. Côté (1985). A histomorphometric assessment of BHT-induced pulmonary toxicity. J. Toxicol. Environ. Health. 15: 125-136.

- M.H. Davies and R.C. Schnell (1987). Comparison of basal glutathione S-transferase activities and of the influence of phenobarbital, buylated hydroxyanisole or $5,5^{\circ}$-diphenylhydantoin on enzyme activity in male rodents. Comp. Biochem. Physiol. 88C: 91-93.

- M.J. De Long, H.J. Prochaska and P. Talalay (1983). Substituted phenols as inducers of enzymes that. inactivate ellectophilic compounds. in: Protective agents in cancer (D.C.H. McBrien and T.F. Slater, Eds.), Academic Press, London, p175-196.

- M.J. De Long, H.J. Prochaska and P. Talalay (1986). Induction of NAD(P)H:quinone reductase in murinbe hepatoma cells by phenolic antioxidants, azo dyes, and other chemoprotectors" a model system for the study of anticarcinogens. Proc. Natl. Acad. Sci. USA 83: 787-791.

- R. Doll and R. Peto (1981). The causes of cancer. J. Nat. Cancer Inst. 66: 1195-1308.

- Dutch Health Council (1985). Advies inzake uitgangspunten voor normstelling. No 31 . (in dutch).

- J. Fereira, L. Coloma, E. Fones, M.E. Letelier, Y. Repetto, A. Morello and J. Aldunate (1988). Effects of t-butyl-4-hydroxyanisole and other phenolic antioxidants on tumoral cells and trypanosoma parasites.
FEBS Lett. 234: 485-488.

- V.J. Feron (1987). Toxiciteitsonderzoek bij proefdieren ter evaluatie van gezondheidsrisico's voor de mens: verworvenheden en beperkingen. Tijdschr. Soc. Gezondheidsz. 65: 35-39. (in dutch).

- J.W. Finley and P. Given Jr. (1986). Technological necessity of antioxidants in the food industry. Food Chem. Toxicol. 24: 999-1006.

A.A. Fisher (1976). Reactions to antioxidants in cosmetics and foods. Cutis 17:21-23.

- E.W. Fisherman and G. Cohen (1973). Chemical intolerance to butylated hydroxyanisole (BHA) and butylated hydroxytoluene (BHT) and vascular response as an indicator and monitor of drug intolerance.
Arnals of Allergy $31: 126-133$.

E.N. Frankel (1987). Secondary products of lipid oxidation. Chem. Phys. Lipids 44: 73-85. D.J. Freeman, G. Wenerstrom and S.L. Spruance (1985). Treatment of recurrent herpes simplex labialis
with topical butylated hydroxytoluene. Clin. Pharmacol. Ther. 38: 56-59.

V.V. Frolkis, R.A. Frolkis, G.Ya. Dubur, Yu.V. Khmelevsky, V.G. Shevchuk, S.F. Golovchenko, L.S. Mkhitarjan, G.S. Voronkov, V.A. Tsyomik, I.V. Lysenko and N.B. Poberezkina (1987).
Antioxidants as antiarnhythmic drugs. Cardiology $74: 124-132$.

K. Furukawa, Y. Maeura, N.T. Furukawa and G.M. Williams (1984). Induction by butylated hydroxyloluene of rat liver gamma-glutamyl transpeptidase activity in comparison to expression in
carcinogen-induced altered lesions. Chem.-Biol. Interact, 48.43 .

response of butylated hydroxyanis, M.A. Shibata, M. Hirose and N. Ito (1987). Different modifying dibutylnitrosamine esophagus and forestomach carcinogenestoluene, and other antioxidants in N,NS. Garattini (1986). Toxic effects of chemicals: difficulties is of rats. Cancer Res. 47: 2113-2116. CRC Crit. Rev. Toxicol. 16: 1-20.

- J.T. MacGregor, D.E. Wilson, W.E. Neff and E.N. Frankel (1985). Mutagenicity test of lipid oxidation products in Salmonella Typhimurium: monohydroperoxides and secondary oxidation products of methyl
linoleate and methyl limolenate. Food Chem. Toxicol. 23: 1041-1047. G. Hageman, R. Kikken, F. ten Hoor and J.C.S. Kleinjans (1988). Assessment of mutagenic activity of
repeatedly used deep-frying fats. Mut. Res. 204: $593-604$. 
- A. Hagiwara, B.A. Diwan and J.M. Ward (1986), Modifying effects of butylated hydroxyanisole, di(2ethylhexyl)phtalate or indomethacin on mouse hepatocarcinogenesis initiated by $\mathrm{N}$-nitrosodiethylamine. Gann 77: 1215-1221.

- $\quad \mathbb{R}$. Haigh (1986). Safety and necessity of antioxidants: EEC approach. Food Chem. Toxicol. 24: 10311034.

- B. Halliwell and J.M.C. Gutteridge (1984). Oxygen toxicity, oxygen radicals, transition metals and disease. Biochem. J. 219: 1-14.

- B.L. Harper and M.S. Legator (1987). Tumor promotors and genotoxic chemicals in short-term testing for carcinogenicity. Adv. Veter. Sci. Comp. Med. 31:1-19.

- M.Q. Hassan, H. Mohammadpour, S.J. Hermansky, W.J. Murray and S.J. Stohs (1987). Comparative effects of BHA and ascorbic acid on the toxicity of $2,3,7,8$-tetrachlorodibenzo-p-dioxin. Gen. Pharmac. 18: 547-550.

- G.A. Hazelton, J.J. Hjelle and C.D. Klaassen (1986). Effects of butylated hydroxyanisole on acetaminophen hepatotoxicity and glucuronidation in vivo. Toxicol. Appl. Pharmacol. 83: 474-485.

- H. Hermo Jr. and P.W. Brandt-Rauf (1987). Chemically induced oncogenesis. Sem. Occup. Med. 2: 235-243.

- H. Hermo Jr. (1987). Chemical carcinogenesis: tumor initiation and promotion. Occup. Med. 2: 1-25.

- M. Hirose, M. Shibata, A. Hagiwara, K. Imaida and N. Ito (1981). Chronic toxicity of butylated hydroxytoluene in Wistar rats. Food Cosmet. Toxicol. 19: 147-151.

- M. Hirose, T. Inoue, M. Asamoto, Y. Tagawa and N. Ito (1986). Comparison of the effects of 13 phenolic compounds in induction of proliferatiwe lesions of the forestonnach and increase in the labelling indices of the glandular stomach and urinary bladder epithelium of syrian golden hamsters. Carcinogenesis 7: 1285-1289.

- M. Hirose, A. Hagiwara, T. Masui, K. Imoue and $N_{n} I t o\left(1986^{b}\right)$. Combined effects of butylated hydroxyanisole and other antioxidants in induction of forestomach lesions in rats. Cancer Lett. 30: 169174.

- M. Hirose, T. Inoue, A. Masuda, H. Tsuda and N. Ito (1987). Effects of simultaneous treatment with various chemicals on BHA-induced development of rat foretomach hyperplasia - complete inhibition by diethylmaleate in a 5-week feeding study. Carcinogenesis 8: 1555-1558.

- G. Hocman (1988), Chemoprevention of cancer phenolic antioxidants (BHT, BHA). Int. J. Biochem. 20: 639-651.

- M.D. Hogan and D.G. Hoel (1982). Extrapolation to man. in: Principles and methods of toxicology. (A. Wallace Hayes, Ed.), Raven Press, New York, p711-731.

- P. Hrelia, L. Murelli, M. Paolini and G. Cantelli-Forti (1987). In vivo protective role of antioxidants against genotoxicity of metronidazole and azanidazole. Drugs Exptl. Clin. Res. XIIr(9): 577-583.

- K. Inai, T. Kobuke, S. Nambu, T. Takemoto, E. Kou, H. Nishina, M. Fulihara, S. Yonehara, S. Suehiro, T. Tsuya ${ }_{n} \mathrm{~K}$. Horiuchi and S. Tokuoka (1988). Hepatocellular tumorigenicity of butylated hydroxytoluene administered orally to B6C3F1 mice. Gann 79: 49-58.

- G.J. Ikeda, J.E. Stewart, P.P. Sapienza, J.O. Peggins III, T.C. Michel, V. Olivito, H.Z. Alam and M.W. O'Donnell Jr. (1986). Effect of subchronic dietary administration of butylated hydroxyanisolle on canine stomach and hepatic tissue. Food Chem. Toxicol. 24: 1201-1221.

- N. Ito, S. Fukushima, A. Hagiwara, M. Shibata and T. Ogiso (1983 $\left.{ }^{\mathrm{a}}\right)$. Carcinogenicity of butylated hydroxyanisole in F344 rats. J. Natl. Cancer Inst. 70; 343-349.

- N. Ito, S. Fukushima, K. Imaida, T. Sakata and T. Masui (1983 $)$. Induction of papilloma in the forestomach of hamsters by butylated hydroxyanisole. Gamn 74: 459-461.

- N. Ito, M. Hirose, Y. Kurata, E. Ikawa, Y. Mera and S. Fukushima (1984). Induction of forestomach hyperplasia by crude butylated hydroxyanisole, a mixture of 3-tert and 2-tert isomers, in syrian golden hamsters is due to 3-tert-butylated hydroxyanisole. Gann 75: 471-474.

- N. Ito, S. Fukushima and H. Tsuda (1985). Carcinogenicity and modilication of the carcinogenic response by BHA, BHT, and other antioxidants. CRC Crit. Rev. Toxicol. 15: 109-150.

- N. Ito, M. Hirose, S. Fukushima, H. Tsuda, T. Shirai and M. Tatematsu (1986 a). Studies on antioxidants: their carcinogenic and modifying effects on chemical carcinogemesis. Food Chem. Toxicol, 24: $1071-1082$. 
- N. lto, S. Fukushima, S. Timano, M. Hirose and A. Hagiwara (1986b). Dose response in butylated hydroxyanisole induction of forestomach carcinogemesis in F344 rats. J. Natl. Cancer Inst. 77: 1261 1265.

- N. 1to (1986). Organ-specific modifying effects of phenobarbital, saccharin and antioxidants on 2-stage chemical carcinogenesis. in: New concepts and developments in toxicology. (P.L. Chambers, P. Gehring and F. Sakai, Eds.), Elsewiers Science Publishers.

N. Ito and M. Hirose (1987). The role of antioxidants in chemical carcinogenesis. Gann 78: 1011-1026.

F. Iverson, E. Lok, E. Nera, K. Karpinski and D.B. Clayson (1985a). A 13-weck feeding study of butylated hydroxyanisole: the subsequent regression of the induced lesions in male Fischer 344 rat forestornach epithelium. Toxicology 35: 1-11.

- F. Iverson, J. Truelove, E. Nera, J. Wong, E. Lok and D.B. Clayson (1985 b). An 85-day study of butylated hydroxyanisole in the cynomolgus monkey. Cancer Lett. 26: 43-50.

E-C. Jhee, L.L. Ho and P.D.Lotikar (1988). Effect of butylated hydroxyanisole pretreatment on in vitro hepatic aflatoxin B1-DNA binding and aflatox in B1-glutathione conjugation in rats. Cancer Res. 48 : 2688-2692.

Joint FAO/WHO Expen Committee on Food Additives (1986a). Toxicological evaluation of certain food additives and contaminants. Butylated hydroxyanisole (BHA). WHO Food Add. Ser. 21: 3-24.

- Joint FAO/WHO Expert Committee on Food Additives $\left(1986^{b}\right)$. Toxicological evaluation of certain food additives and contaminants. Butylated hydroxytol urene (BHT). WHO Food Add. Ser. 21:25-46.

- Joint FAO/WHO Expert Committee on Food Additives (19.89). Evaluation of certain food additives and contaminants. WHO Technical Report Series 776: 14-15.

- R. Kahl (1984). Synthetic antioxidants: biochemical actions and interference with radiation, toxic compounds, chemical mutagens and chemical carcinogens. Toxicology 33: 185-228.

- R. Kathl (1986). The dual role of antioxidants in the modification of chemical carcinogenesis. I. Environ. Sci. Healih C4(1): 47-92.

- J.P. Kehrer and H.P. Witschi (1980). Effects of drug metabolism inhibitors on butylated hydroxytoluenc-induced pulmonary damage in mice. Toxicol. Appl. Pharmacol. 53: 333-342.

- K.T. Kitchin and J.L. Brown (1987). Biochemical effects of two promotors of thepatocarcinogenesis in rats. Food Chern. Toxicol. 25: 603-607.

J. Kleinjans, H. Verhagen, G. Hageman and $F$, ten Hoor (1987). De carcinogeniteit van de voedingsmiddelenadditieven butylhydroxytolueen en butylhydroxyanisol. Een literatuurstudie. Voeding 48: 153-158. (in dutch).

- R. Kroes (1987). Contribution of toxicology towards risk assessment of carcinogens. Arch. Toxicol. 60 : 224-228.

- L.K.T. Lam (1988). Effects of butylated hydroxyanisole on glutathione S-transferase and catechol Omethyliransferase activities in Syrian golden hamsters. Biochem. Pharmacol. 37: 3011-3016.

- R.C. Lindenschmidt A.F. Tryka, M.E. Goad and H.P. Witschi (1986). The effects of dietary butylated hydroxytoluene on liver and colon tumor development in mice. Toxicology 38: 151-160.

R.C. Lindenschmidt, A.F. Tryka and H.P. Witschi (1987). Modification of gastrointestinal tumor development in rats by dietary butylated hydroxytoluene. Fundam. Appl. Toxicol. 8: 474-481.

M.K. Logani and R.E. Davies (1980). Lipid oxidation: biological effects and antioxidants - a revicw. Lipids 15: 485-495.

- A.M. Malkinson (1983). Review: putative mutagens and carcinogens in foods. III Butylated hydroxyloluene (BHT), Environ. Mutagen. 5: 353-362.

- A.A. Marino and J.T. Mitchell (1972). Lung damage in mice following intraperitoneal injection of butylated hydroxytoluene. Proc. Soc. Exp. Biol. Med. 140: 122-125.

- T. Masui, M. Asamoto, M. Hirose, S. Fukushima and N. Ito (1987). Regression of simple hyperplasia and papillomas and persistence od basal cell hyperplasia in the forestomach of F344 rats treated with butylated hydroxyanisole. Cancer Res. 47: 5171-5174.

- T. Masui, S. Fukushima, F. Katoh, H. Yarnasaki and N. Ito (1988). Effects of sodium L-ascorbate, uracill, butyllated hydroxyanisole and extracellular $\mathrm{pH}$ on junctional intercellular communication of BALB/c 3T3 cells. Carcinogenesis 9: 1143-1146.

- D.H. Monroe, C.J. Holeski and D.L. Eaton (1986). Effects of single-dose and repeated-dose pretreatment with 2(3)-tert-butyl-4-hydroxyamisole (BHA) on the hepatobiliary disposition and covalent binding to
DNA of aflatoxin B1 in the rat. Food Chem. Toxicol. 24: 1273-1281. 
- M.A. Moore, W. Thamavit and N. Ito (1987ay. Comparison of lesions induced in the syrian golden hamster by diethylnitrosamine, dimethylhydrazine, and dibutylnitrosanuine: influcnce of subsequent butylated hydroxyanisole treatment. I. Natll. Cancer lnst. 78: 295-301.

- M.A. Moore, H. Tsuda, W. Thamavit, T. Masui and N. Ito ( $\left.1987^{b}\right)$. Differential modification of dewelopment of preneoplastic lesions in the syrian golden thamster initated with a single dose of 2,2 dioxo-N-nitrosodipropylamine: influence of subsequent butylated hydroxyanisole, alpha-tocopherol, or carbazole. J. Natl. Cancer Inst. 78: 289-293.

- M.A. Moore, W. Thamavit, Y. Hiasa and N. Ito (1988). Early lesions induced by DHPN in syrian golden hamsters: influence of concomitant Opisthonchis infestation, dehydroepiandosterone or butylated hydroxyanisole administration. Carcinogenesis 9: 1185-1189.

- Y. Nakagawa, K. Tayama, T. Nakao and K. Hiraga (1984). On the mechanism of butylated hydroxytoluenc-induced hepatic toxicity in rats. Biochem. Pharmacol. 33: 2669-2674.

- Y. Nakagawa and $\mathrm{K}$. Tayama (1988). Nephrotoxicity of butylated hydroxytoluene in phenobarbitallpretreated male rats. Arch. Toxicol. 61: 359-365.

- E.A. Nera, E. Lok, F. Iverson, E. Orrnsby, K.F. Karpinski and D.B. Clayson (1984). Short-tern pathological and proliferative effects of butylated hydroxyanisole and other phenolic antioxidants in the forestomach of Fischer 344 rats. Toxicology 32: 197-213.

- P. M. Newberne, G. Chamley, K. Adams, M. Cantor, D. Roth, V. Supharkarn and L. Fong (1986). Gastric and oesophageal carcinogenesis: models for the identification of risk and protective factors. Food Chem. Toxicol. 24: 1111-1119.

- P. Olsen (1983). The cancinogenic effect of butylated hydroxyanisole on the stratified epitheliun of the stomach in rat versus pig. Cancer Lett. 21: 115-116.

- P. Olsen, O. Meyer, N. Bille and G. Würtzen (1986). Carcinogenicity study on butylated hydroxytoluene (BHT) in Wistar rats exposed in utero. Food Chem. Toxicol. 24: 1-12.

- C.N. Park and R.D. Snec (1983). Quantitative risk assessment: state-of-the-art for carcinogenesis. Am. Statis. 37: 427-441.

- R.M. Patterson, L.A. Keith and J. Stewart (1987). Increase in chromosomal abnormalities in chincse hamster ovary cells treated with butylated hydroxytoluene in vitro. Toxicol. in Vitro 1: 55-57.

- D. Pearson and S. Shaw (1982). Life extension. A practical scientific approach. Warner Books, New York.

- W.R. Pearson, J. Reinhart, S.C. Sisk, K.S. Anderson and P.N. Adler (1988), Tissue-specific induction of murine glutathione transferase mRNAs by butylated hydroxyanisole. J. Biol. Chem. 263: 1332413332.

- J. Pincemail, C. Deby, A. Dethier, Y. Bertrand, M. Lismonde and M. Lamy (1987). Pentane measurement in man as an index of lipoperoxidation. Bioelectrochem. Bioenerg. 18: 117-125.

J. Potenberg, D. Schiffmann, R. Kahl i, A.G. Hildebrandt and D. Henschler (1986). Modulation of benzo(a)pyrene-induced morphological transformation of syrian hamster embryo cells by butylatcd hydroxytoluene and butylated hydroxyanisole. Cancer Lett. 33: 189-198.

- C.J. Powell, J.C. Connelly, S.M. Jones, P. Grasso and J.W. Bridges (1986), Hepatic responses to the administration of high dose of BHT to the rat: their relevance to hepatocarcinogenicity. Food Chern. Toxicol. 24: 1131-1143.

- R. Rehwoldt (1986). Tracking the use of antioxidants through industry surveys. Food Chem. Toxicol. 24: 1039-1041.

- C. Rodrigues, E. Lok, E. Nera, F. Iverson, D. Page, K. Karpinski and D. B. Clayson (1986). Short-term effects of various phenols and acids on the Fischer 344 rat forestomach epithelium. Toxicology 38: 103117.

- J. Roed-Petersen and N. Hjorth (1976). Contact dermatitis from antioxidants. Br. J. Dermatol. 94: 233. 241.

- M. Saito, Y. Ohkawa and N. Inui. (1986). Retinoic acid and butylated hydroxyanisole inhibüt promoterenhanced transformation in vitro. Cancer Lett. 33: 161-165.

- Scientific Review Group (1985). Saccharin - current status. Food Chem. Toxicol. 23: 543-546"

- L.J. Sciorra, B.N. Kaufmann and R. Maier (1974). The effects of butylated hydroxytoluene on the cell cycle and chromosome morphology of phytohaemagglutaninin-stimulated leucocyte cultures. Food Cosmet. Toxicol. 12: 33-44.

- A. Sevenian and P. Hochstcin (1985). Mechanism and consequences of lipid peroxidation in biological systems. Ann. Rew. Nutr. 5: 365-390. 
- D.M. Shlian and J. Goldstone (1986). Toxicily of butylated hydroxytoluene. New Engl. J. Med. 314: 648-649.

- R.J. Sins and J.A. Fioriti (1980). Antioxidants as stabilizers for fats, oils, and lipid-containing foods. in T.E. Furia (Ed.) CRC Handbook of Food Additives, volume II, CRC Press, Boca Raton, FL. p13-56.

- S.Y. Singh, G. Creadon, M. Das, H. Mukhtar and Y.C. Awasth (1987). Glutathione S-transferases of mouse lung. Selective binding of benzo(a)pyrene metabolites by the subunits which are preferentially induced by $t$-butylated hydroxyanisole. Biochem. J. 243: 351-358.

- P.M. Sokolove; E.X. Albuquerque, F.C. Kaufmann, T.F. Spande and J.W. Daly (1986). Phenolic antioxidants potent inhibitors of the $\left(\mathrm{Ca}^{2+}+\mathrm{Mg}^{2+}\right)$-ATPase of sarcoplasmic reticulum. FEBS Lett. 203: $121-126$.

- 3. Stewart and C.M. Boston (1987). Effect of pretreatment with 3-methylcholanthrene and several phenolic antioxidants on glutathione S-transferase activity in various tissues of female Sprague-Dawley rats. Xenobiotica 17: 679-684.

- H. Suzuki, T. Nakao and K. Hiraga (1979). Vitamin K deficiency in male rats fed diets containing butylated hydroxytoluene (BHT). Toxicol. Appl. Pharmacol. 50: 261-266.

- $\quad$. Takahashi and K. Hiraga (1978). Dose-response study of haemorrhagic death by dietary butylated hydroxytoluene (BHT) in male rats. Toxicol. Appl. Pharmacol. 43: 399-406.

- O. Takahashi and K. Hiraga (1981). Haemorrhagic toxicosis in rats given butylated hydroxytoluene. Acta Pharmacol. Toxicol. 49: 14-20.

- O. Takahashi $Y$. Sakamoto and K. Hiraga (1985). Lung hemorrhagic toxicicy of butylated hydroxyanisole in the rat. Toxicol. Lett. 27: 15-25.

- O. Takahashi (1987). Decrease in blood coagulation factors II (prothrombin), VII, IX and X in the rat after a single oral dose of butylated hydroxytoluene. Food Chem. Toxicol. 25: 219-224.

- M. Tatematsu, Y. Mera, K. Kohda, Y. Kawazoe and N. Ito (1986). Omithine decarboxylase activity and DNA synuhesis in rats after long term treatment with butylated hydroxyanisole, sodium saccharin or phenobarbital . Cancer Lett. 33: 119-124.

- D.C. Thompson and M.A. Trush (1986). The toxicological implications of the interaction of butylated hydroxytoluene with other antioxidants and phenolic chemicals. Food Chem. Toxicol. 24: 1189-1195.

- D.C. Thompson and M.A. Trush (1988). Enthancement of butylated hydroxytoluene-indluced mouse lung damage by butylated hydroxyanisole. Toxicol. Appl. Pharmacol. 96: 115-121.

- D.C. Thompson and M.A. Trush (1988 by). Studies on the mechanism of enhancement of butylated hydroxytoluene-induced mouse lung toxicity by butylated hydroxyanisole. Toxicol. Appl. Pharmacol. 96: $122-131$.

- D. Thompson and P. Moldéus (1988). Cytotoxicity of butylated hydroxyanisole and butylated hydroxytoluente in isolated rat hepatocytes. Biochem. Pharmacol. 37: 2201-2207.

M. Tobe, T. Furuya, Y. Kawasaki, K. Naito, K. Sekíta, K. Matsumoto, T. Ochiai, A. Usui, T. Kokubo, J. Kanmo and $Y$. Hayashi (1986). Six-month toxicity study of butylated hydroxyanisole in Beagle dogs. Food Chem. Toxicol. 24: 1223-1228.

- C.E. Vaca, J. Wilhelm and M. Harms-Ringdahl (1988). Interaction of Jipid peroxidation products with DNA. A review. Mut. Res, 195: 137-149.

- C.R. Warner, D.H. Daniels, F.S.D. Lin, F.L. Joe Jr and T. Fazio (1986 ${ }^{\mathrm{a}}$ ). Fate of antioxidants and antioxidant-derived products in deep-fat frying and cookie baking. J. Agric. Food Chem. $34: 1-5$.

- C.R. Warner, W.C. Brumley, D.H. Daniels, F.L. Joe Jr. and T. Fazio (1986 b). Reactions of antioxidants in foods. Food Chem. Toxicol. 24: 1015-1019.

- L.W. Wattenberg, J.B. Coccia and L.K.T. Lam (1980). Inhibitory effets of phenolic compounds on benzo(a)pyrene-induced neoplasia. Cancer Res, 40: 2820-2823.

- L.W. Wattenberg (1985). Chemoprevention of cancer. Cancer Res. 45: 1-8.

- L.W. Wattenberg (1986). Protective effects of 2(3)-tert-butyl-4-hydroxyanisole on chemical carcinogenesis. Food Chem. Toxicol. 24: 1099-1102.

I.R. White, C.R. Lovell and E. Cronin (1984). Antioxidants in cosmetics. Contact Dermatitis 11: 265267.

- M. Windholz, S. Budavari, R.F. Blumetti and E.S. Otterbein (1983). The Merck Index, $10^{\text {th }}$ edition, Merck \& Co., Rahway, NJ., USA, p215-216.

- H.P. Witschi (1986). Enhanced tumour development by butylated hydroxytoluene (BHT) in the liver. lung and gastro-intestinal tract. Food Chem. Toxicol. 24: 1127-1130. 
- G. Wurtzen and P. Olsen (1986a). BHA study in pigs. Food Chem. Toxicol. 24: 1229-1233.

- G. Woirtzen and P. Olsen (1986 b). Chronic study on BHT in rats. Food Chem. Toxicol. 24: 1121-1125.

- K. Yamamoto, K. Tajima, N. Okino and T. Mizutani (1988). Enhanced lung toxicity of butylated hydroxytoluene in mice by coadministration of butylated hydroxyanisole. Res. Commun. Chem. Pathol. Pharmacol. 59: 219-231.

- E. Young, S. Patel, M. Stoncham, R. Rona and J.D. Wilkinson (1987). The prevalence of reaction to food additives in a survey population. J. Royal Coll. Phys. London 21: 241-247.

L. Zeise, R. Wilson and E.A.C. Crouch (1987). Dose-response relationships for carcinogens: a review. Environ. Health Perspec. 73: 259-308. 


\section{PART I}

ANALYTICAL PROCEDURES 



\title{
Chapter 2
}

\section{Sensitive high-performance liquid chromatographic method for the routine determination of butylated hydroxyanisole in plasma}

\author{
Hans Verhagen, Henk H.W. Thijssen and Jos C.S. Kleinjans \\ Journal of Chromatography 413 (1987) 282-286
}

\section{Introduction}

Butylated hydroxyanisole (2(3)-tert-butyl-4-hydroxyanisole, BHA, Fig. 2-1) is widely used in foods, cosmetics and plastics for its radicall trapping and therefore antioxidative properties (1-3). Owing to the large-scale use of BHA, its possible toxicity to man is of great interest. Earlier studies regarded the application of BHA as a food additive to be safe, especially when considering its expected low dietary intake (4). Further, BHA was observed to act as an anticarcinogen in various animal carcinogenesis models (2,5). However, chronic feeding of BHA at relatively high doses has recently been reported to induce hyperplasia in rodent forestomach (6) and to increase mitotic index in primate oesophagus (7), thus revealing some carcinogenic potential.

Further evaluation of the toxicological properties of BHA demands a critical assessment of its toxicokinetic characteristics. However only a few methods for the determination of BHA in animal and human plasma are available, all of them involving gas chromatography (GC) $(8,9)$ or gas chromatography-mass spectrometry (GC-MS) $(10-12)$. There is no uniformity in the extraction procedure for BHA from plasma. Further, a routine high-performance liquid chromatographic (HPLC) method for the determination of BHA in plasma has not yet been established.

This paper describes a simple and rapid procedure for the extraction of BHA from plasma and its quantization by means of reversed-phase HPLC with fluorescence detection.
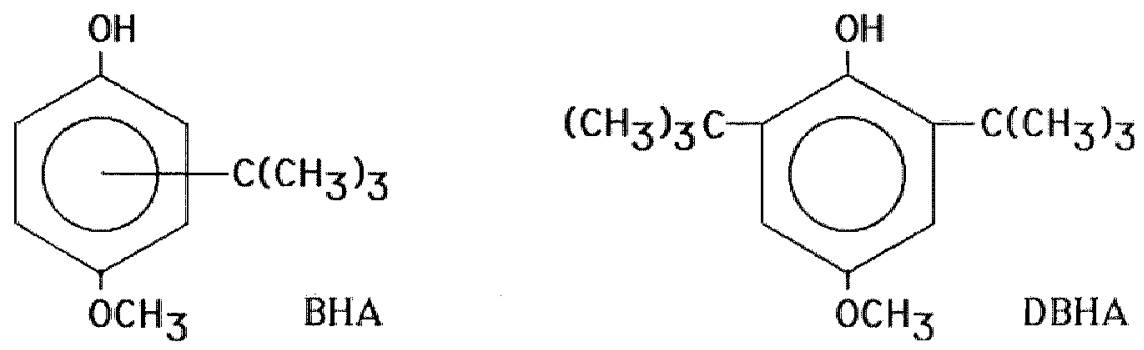

Figure 2-1: Structures of (A) 2(3)-tert-butyl-4-hydroxyanisole (BIIA) and (B) 3.5-di-tert-butyl-4hydroxyanisole (DBHA). 


\section{Experimental}

\section{Chemicals and materials}

BHA (3.5-4\% 2 tent-butyl-4-hydroxyanisole plus 94-96\% 3-tert-butyl-4-hydroxyanisole) was obtained from Sigma (St, Lous: MO, U.S,A.) and DBHA (3,5-di-tert-butyl-4-hydroxyanisole) (Fig. 1) from Aldrich (Brussels, Belgium). Methanol (HPLC grade) and diethyl ether were purchased from Merck (Darmstadt, F.E.G. . Water was purfied using a Milli-Q water purification system. Analytical-reagent grade chemicals were used in all other instances.

Pool plastma was prepared from fresh citrated bovine blood, obtained from a neighborthood slaughterhouse.

\section{Extraction of plasma}

Pool plasma was spiked with known amounts of BHA in methanol to achieve plasma concentrations in the range $0-100 \mu \mathrm{g} / \mathrm{ml}$. The final methanol concentration never exceeded $1 \%$.

A $0.1-1.0 \mathrm{ml}$ volume of this BHA-loaded plasma was diluted to $1.0 \mathrm{ml}$ with water and $25 \mu$ methanol containing $80 \mu \mathrm{g}$ DBHA/ml was added as an internal standard. Subsequently $5.0 \mathrm{ml}$ of diethyl ether was added to the glass stoppered tubes for the extraction of BHA and DBHA. The samples were shaken for $1 \mathrm{~h}$ and centrifuged at $700 \mathrm{~g}$ for 5 min. A $4.5-\mathrm{ml}$ volume of the organic phase was evaporated to dryness at $0{ }^{\circ} \mathrm{C}$ under a gentle stream of nitrogen. The residue was dissolved in $90 \mu \mathrm{l}$ of methanol and retained until analysis.

\section{High-performance liquid chromatography}

The HPLC system consisted of a Kratos Spectroflow 400 pump and a Kratos Spectrollow 980 programmable fluorescence detector with an excitation wavelength of $290 \mathrm{~nm}$ and a cut-off filter at $320 \mathrm{~nm}$. Injections were performed yia a $20-\mu$ l sample loop of a Rheodyne 7125 syringe loading sample injector.

A LiChrosorb 5 RP-18 (150 mm $\times 4.6 \mathrm{~mm}$ I.D.) (Chrompack, Middelburg, The Netherlands) was used in combination with a guard column (ODS pellicular material) $(30 \mathrm{~mm} \times 2.1 \mathrm{~mm}$.D. ). The mobile phase, modified from the medhod of Archer (13), consisted of $1 \%$ acetic acid in methanol-water $(73: 27, v / v)$. The eluent, which had been degassed prior to use in an ultrasonic water-bath, was recycled at a flow-rate of 2.0 ml/min and kept at $40^{\circ} \mathrm{C}$ to prevent the introduction of air.

The two isomeric forms of BHA are not separated by this procedure.

\section{Animal experiments}

Two male Wistar rats ( 307 and $318 \mathrm{~g}$ ) (TNO, Rijswijk, The Netherlands) received a catheter into the right femoral artery under ether anaesthesia and $24 \mathrm{~h}$ after surgery the rats, fasted overnight, were given by gavage $1 \mathrm{ml} / \mathrm{kg}$ of a solution containing $200 \mathrm{mg} / \mathrm{ml} \mathrm{BHA}$ in dimethylsulphoxide (DMSO) (11). Blond samples of $200-250 \mu \mathrm{l}$ were taken from the femoral artery after 0 (control), 10,20,30,50,70,90,120,180, 240 and $360 \mathrm{~min}$, collected in heparinized vessels, and centrifuged for $5 \mathrm{~min}$ at $2000 \mathrm{~g}$. Plasma was stored at $-20^{\circ} \mathrm{C}$ until taken for anaiysis. In order to protect the animals from anaemia, $1 \mathrm{ml}$ of washed blood cells, dilutod 1:1 with saline, was re-administered after the $120-\mathrm{min}$ blood sample had been taken.

\section{Results and discussion}

\section{Extraction procedure}

Several procedures for the extraction of BHA from animal or human plasma have been described (8-12). Dichloromethane, hexane and light petroleum thave been applied for this purpose, and diethyl ether was used to extract BHA from urine (14). In our experience, several solvents (dichloromethane, chloroform, hexane, ethyl acetate, diethyl ether) are suitable for the extraction of BHA from plasma.

However, because phenolic antioxidants are volatile (3), evaporation to dryness after extraction appeared to be the most delicate step in the procedure. Indeed, most of the amounts of BHA and DBHA dissolved in methanol, which was evaporated under nitrogen at $40^{\circ} \mathrm{C}$, could be trapped in a filter filled with activated charcoal and placed on top of the evaporation tube, the filter subsequently being eluted with methanol and the extract analysed by HPLC. Since, in a separate experiment, BHA and DBHA could be retained by means of 
a tiny drop of oil added to the extraction solvent which was evaporated at $40^{\circ} \mathrm{C}$, it is suggested that the amount of co-extracted lipid material from plasma contributes to avoiding sublimation of BHA and DBHA at higher temperatures. To avoid this volatility phenomenon of $\mathrm{BHA}$, in our study plasma extracts were ewaporated at $0^{\circ} \mathrm{C}$ and diethyl ether was chosen as the extraction solvent because of its ease of evaporation at $0^{\circ} \mathrm{C}$,

\section{Chromatography}

The retention times of BHA and DBHA were 1.9 and $5.1 \mathrm{~min}$, respectively, and the total run time was $12 \mathrm{~min}$. We have found that fluorescence detection is both selective and sensitive for BHA. Typical chromatograms are shown in Fig. 2-2. Blank plasma extracts did not reveal any peaks at the locations of BHA or DBHA.

Calibration graphs, calculated from peak-height ratios, showed good linearity over the range $0-100 \mu \mathrm{g} / \mathrm{ml}$ BHA (Fig. 2-3). The recovery of BHA, calculated from spiked 500 and 1000 $\mathrm{ng} / \mathrm{ml}$ plasma samples, was $90 \pm 6 \%$ (mean $\pm S . D ., n=10$ ). The limit of detection of BHA was $1 \mathrm{ng}$ absolute (signal-to-noise ratio $=5$ ). In our plasma samples concentrations up to 10 $\mathrm{ng} / \mathrm{ml}$ could be assayed accurately (Fig. 2-2B). The coefficient of variation for the assay procedure as determined for spiked 0.5 and $100 \mu \mathrm{g} / \mathrm{ml}$ samples was $4-5 \%(\mathrm{n}=8)$. These results are compatible with reported methods involving GC $(8,9)$ or GC-MS (10-12).

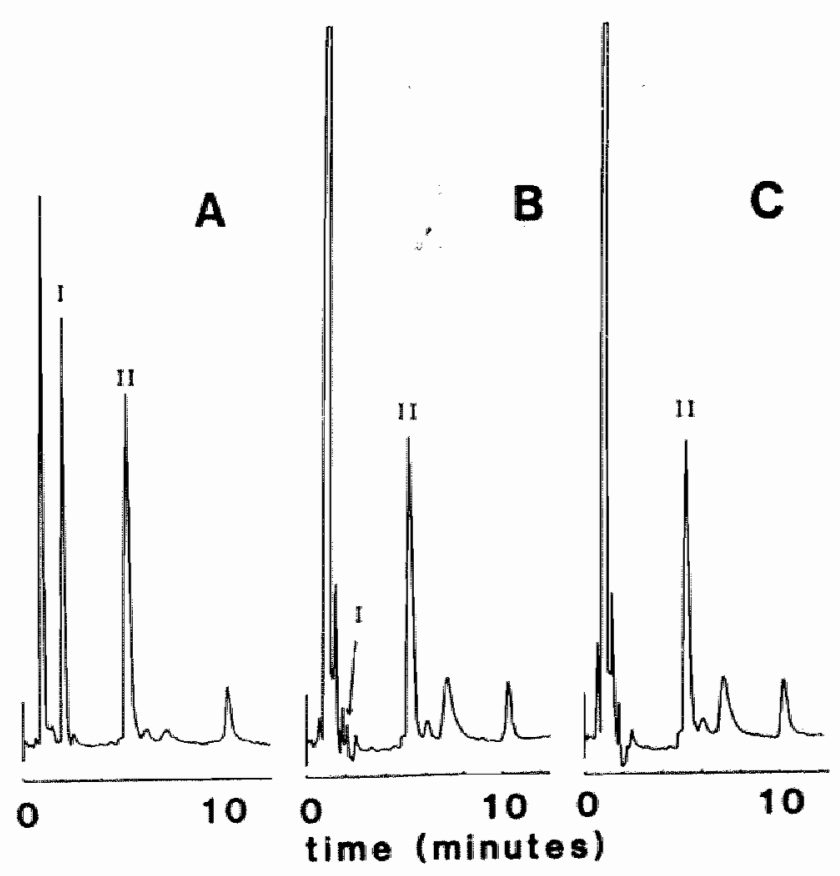

Figure 2-2: Chromatograms of BHA (I) assay in plasma using DBHA (II) as an internal standard. (A) Extract of $100 \mu$ of plasma spiked with $1000 \mathrm{ng} / \mathrm{ml}$ BHA; (B) ten-fold concentrated extract of $1 \mathrm{ml}$ of plasma spiked with $10 \mathrm{ng} / \mathrm{ml} \mathrm{Bl} / \mathrm{A}$; (C) ten-fold concentrated extract of $1 \mathrm{ml}$ of blank plasma. Chromalograms were recorded using a programmable fluorescence deteclor with a range set at $0.007 \mathrm{AU}$ between 0 and 2.5 min and at 0.020 AU between 2.5 and 12 min. Aluto-zeros were given at $t=0,1.6,2.5$ and $4.8 \mathrm{~min}$. 

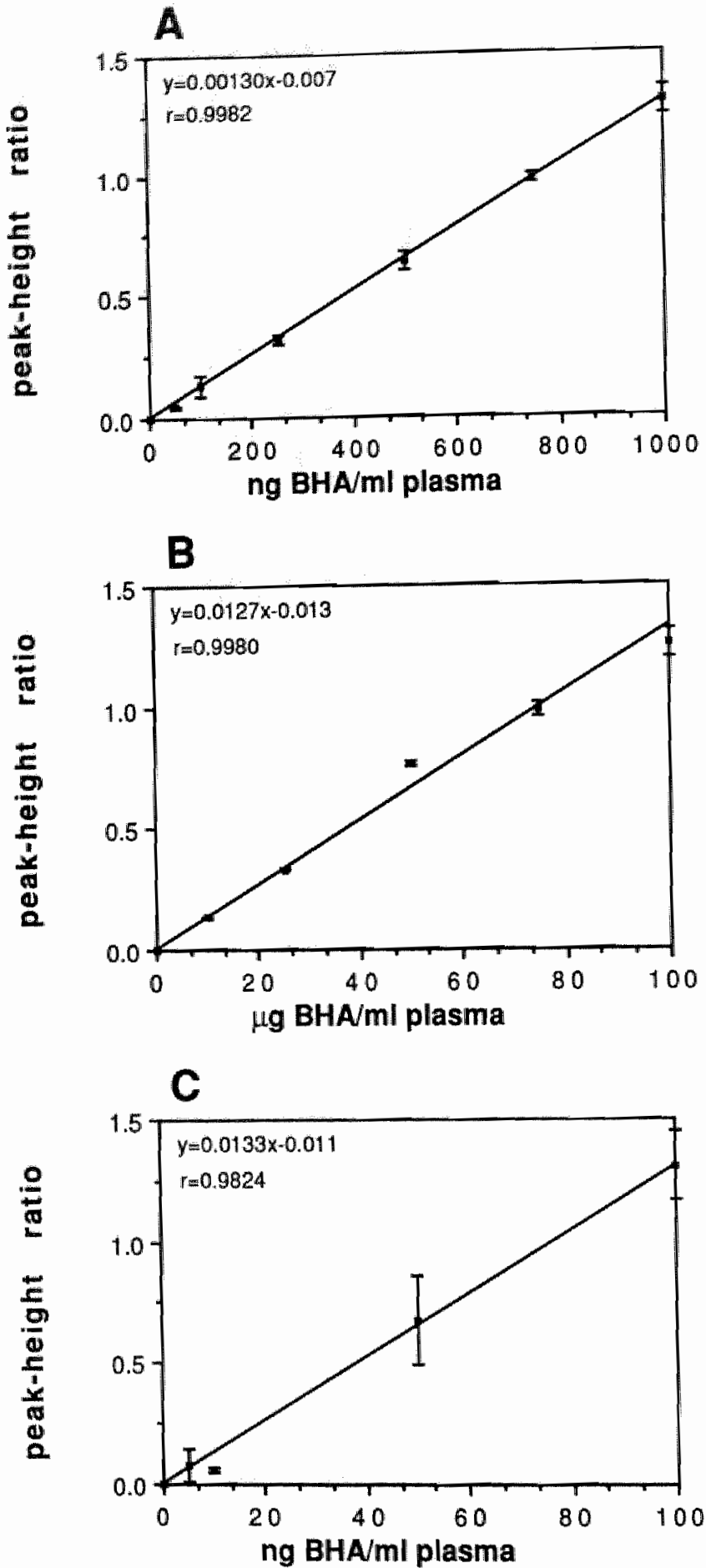

Figure 2-3: Calibration graphs for BHA extracted from spiked plasma samples using DBHA as an iniernal

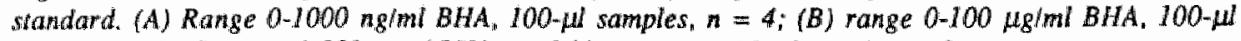
samples, $n=4,(C)$ range $0.100 \mathrm{ng} / \mathrm{ml}$ BHA, ten-fold concentrated I $\mathrm{ml}$ samples, $n=3$. 
Animal experiments

Plasma concentration-time curves for BHA in two rats following its oral administration are presented in Fig. 2-4. In one rat a plasma BHA peak concentration was observed at 30 min; no BHA peak was observed in the other rat. The elimination of BHA from plasma seemed to be slow. These preliminary data are in agreement with those of Bailey et al. (11). Detailed toxicokinetic studies of BHA in the rat are currently being undertaken.

To our knowled ge this is the first reported HPLC method for the determination of BHA in plasma, which in our hands proved also to be applicable to the determination of BHA in urine.

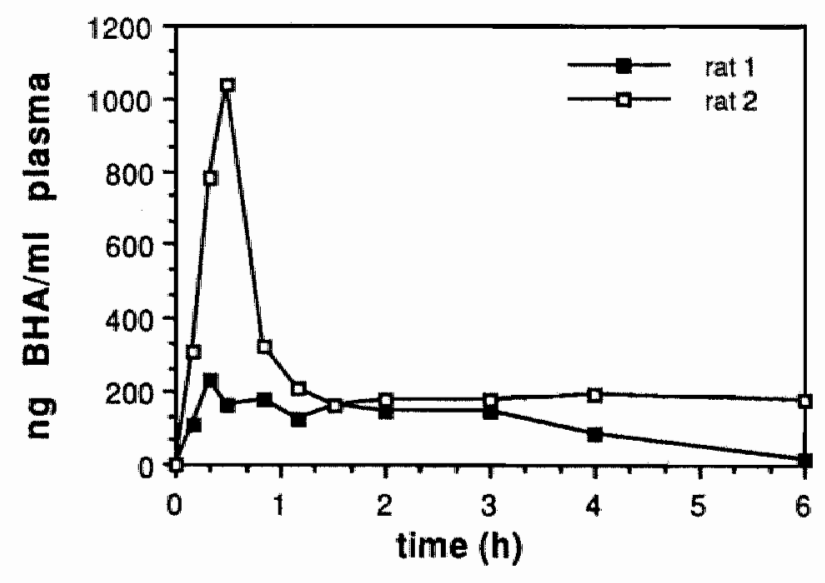

Figure 2-4: BHA concentrations in plasma of two rats sampled at various times after in gastro administration of $200 \mathrm{mg} / \mathrm{kg}$ BHA in DMSO.

\section{References}

1. Sims, R.J. and J.A. Fioriti. In: T.E. Furia (cditor). CRC Handbook of Food Additives, Vol. II, Chemical Rubber Co., Boca Raton, FL, 2nd ed., 1980, p. 13.

2. Anonymous, J. Am. Coll. Toxicol., 3 (1984) 83.

3. Vimalasiri, P.A.D.T., J.K. Haken and R.P. Burford. J. Chromatogr., 300 (1984) 303.

4. Branen, A.L., J. Am. Oil Chem. Soc., 52 (1975) 59.

5. Wattenberg, L.W., J. Environ. Pathol, Toxicol., 3 (1980) 35.

6. Ito, N., S. Fukushima and H. Tsuda, CRC Crit. Rev. Toxicol. 15 (198:5) 109.

7. Iverson, F., J. Truelove, E. Nera, J. Wong, E. Lok and D.B. Clayson. Cancer Leth., 26 (1985) 43.

8. El-Rashidy R. and S. Niazi. J. Pharm. Sci. 68 (1979) 103.

9. El-Rashidy R. and S. Niazi. J. Pharm. Sci. 69 (1980) 1455.

10. Castelli, M.G., E. Benfenati, R. Pastorelli, M. Salmona and R. Fanelli. Food Chem. Toxicol. 22 (1984) 901.

11. Bailey E., L. Della Corte, P.B. Farmer and A.J. Gray, J. Chromatogr., 225 (1981) 83.

12. Guarna A., L. Della Corte, M.G. Giovannini, F. de Sarlo and S. Sgaragli. Drug Metab. Dispos., 11 (1983) 581 .

13. Archer, A.W., Anal. Chim. Acta, 128 (1981) 235.

14. Astill, B.D., D.W. Fasseu and R.L. Roudabush. Biochem. J. 75 (1960) 543. 



\title{
Chapter 3
}

\section{Determination of butylated hydroxytoluene in plasma by high-performance liquid chromatography}

\author{
Hans Verhagen, Henk H.W. Thijssen and Jos C.S. Kleinjans \\ Journal of Chromatography 422 (1987) 288-293
}

\section{Introduction}

Butyllated hydroxytoluene (3,5-di-tert-butyl-4-hydroxytoluene, BHT, Fig. 3-1) and butylated hydroxyanisole (2-(3-)tert-butyl-4-hydroxyanisole, BHA, Fig 3-1) are phenolic antioxidants widely used in foods and technical products $(1-3)$. The toxicity of BHT in animals is well documented (2-4). It has been shown that rodent liver and lungs are especially susceptible to the toxic effects of BHT $(5,6)$. BHT interferes with blood coagulation and causes hemorrhagic death in rats (7). Furthermore, BHT and BHA appear to have a dual role in the modification of chemical carcinogenesis, exhibiting pro- as well as anti-carcinogenic properties $(8,9)$. The incidence of mild hyperplasia in hamster forestomach was slightly higher after oral BHT intake (10). BHT acts as a full carcinogen in lungs and liver of rodents $(9,11,12)$.

Analysis of the in vivo kinetics and metabolism of BHT may contribute to the evaluation of its potential health risk. In this respect, only a few methods for the determination of BHT in plasma or serum have been reported, applying radio-activity (13), gas chromatography (GC) $(14,15)$, gas chromatography-mass-spectrometry (GC-MS) (16) or high-performance liquid chromatography (HPLC) with ultraviolet (UV) detection and gradient elution (17).

We recently reported a sensitive method for the routine determination of butylated hydroxyanisole in plasma (18). This paper describes a simple procedure for the routine determination of BHT in plasma by means of reversed-phase HPLC with isocratic elution and fluorescence detection.

\section{Experimental}

Chemicals and materials

BHT and BHA were obtained from Sigma (St. Louis, MO, USA); DBHA (3,5-di-tert-butyl-4 hydroxyanisole, Fig. 3-1) and MBHT (3-mono-tert-butyl-4-thydroxytoluene, Fig. 3-1) were purchased from Aldrich (Brussels, Belgium). Acetonitrile (HPLC-grade) was purchased from Rathburn (Walkerburn, Scotland). Diethyl ether, stabilized with pyrogallol instead of BHT, was obtained from BDH (Poole, U.K.). Water was purified using a Milli-Q water purification system. Analytical-reagent grade chemicals were used in all other instances. Plasma prepared from fresh citrated bovine blood was used for constructing calibration graphs.

\section{Preparation of samples}

Aliquots of plasma $(0.2-1.0 \mathrm{ml}$, spiked with $0-5000 \mathrm{ng} / \mathrm{ml}$ BHT for callibration graphs) were diluted to 1.0 $\mathrm{ml}$ with water. A $25 \mu \mathrm{l}$ aliquot of a solution of $100 \mu \mathrm{g} / \mathrm{ml}$ DBHA in methanol was added as an internal standard. Samples were subsequently extracted in a glass stoppered tube with $5 \mathrm{ml}$ of oil-enriched diethyll 
cther (one drop of corn oil in $200 \mathrm{ml}$ diethyllether). The samples were shaken for $0.5 \mathrm{~h}$ and centrifuged at 700 8 for $5 \mathrm{~min}$. The organic phiase was separated and evaporated to dryness at $0^{\circ} \mathrm{C}$ under a gentle strcam of

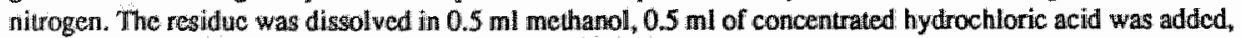
and the stoppered twbes were incubated for $1 \mathrm{~h}$ at $95^{\circ} \mathrm{C}$ in a shaking water-bath in order to de-alkylate BHT and DBHA to thicir strongly fluorescent counterparts MBHT and 3-BHA (Fig. 3-1), respectively. After cooling on ice, the samples were diluted with $2.5 \mathrm{ml}$ water, extracted for $0.5 \mathrm{~h}$ with $5 \mathrm{ml}$ diechyl ether, contifuged at $700 \mathrm{~g}$ for $5 \mathrm{~min}$ and evaporated to dryness at $0^{\circ} \mathrm{C}$ under a gentle stream of nitrogen. The residue was dissolved in $500 \mu$ of eluent and stored prior to analysis.

\section{High-performance liquid chromatography}

HPLC-analysis was performed with a Kratos Spectroflow 400 pump and a Kratos Spectroflow 980 programmable fluorescence detector. A LiChrosorb RP-18 caruidge column and appropriate guard column (Chrompack, Middclburg. The Netherlands) were used. The excitation wavelength was set at $273 \mathrm{~nm}$ and a cut-off filter at $320 \mathrm{~nm}$ was uscd. Samples of $100 \mu \mathrm{l}$ were injected with a Rheodyne 7125 sample injector. The solvent, acctonitrile-water-acetic acidl (45:54:1, v/v/v), was degassed prior to use in an ultrasonic bath and recycled at a flow-rate of $1.0 \mathrm{ml} / \mathrm{min}$.

\section{Animal experiments}

A catheter was placed under ether anaesthesia into the right femoral artery of two malle Wistar rats (294 and $300 \mathrm{~g}$; Winkelmann, Borchem, FRG). After fasting overnight the rats received an oral dose of $200 \mathrm{mg} / \mathrm{kg}$ BHT, as a solution of $200 \mathrm{mg} / \mathrm{ml} \mathrm{BHT}$ in corn oil. Blood was sampled at $0,15,30,45,60,90,120,180$, 240,360 and 480 minutes after administration. Blood samples of $400-450 \mu l$ were collected in heparanized vessels and centrifuged at $2000 \mathrm{~g}$ for $5 \mathrm{~min}$. Prior to analy sis, plasma was stored at $-20{ }^{\circ} \mathrm{C}$. Washed blood cells $(0.5 \mathrm{mi})$ mixed with $0.5 \mathrm{ml}$ saline were readministered after 90 and $180 \mathrm{~min}$ in order to protect the animals from anaemia.<smiles>Cc1cc(C(C)(C)C)c(O)c(C(C)(C)C)c1</smiles><smiles>Cc1ccc(O)c(C(C)(C)C)c1</smiles><smiles>COc1cc(C(C)(C)C)c(O)c(C(C)(C)C)c1</smiles>

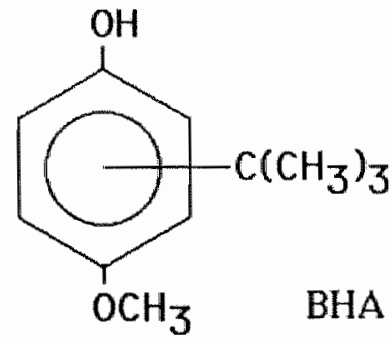

Figure 3-1: Structures of (A) 3,5-di-terl-butyl-4-hydroxytolwene (BHT), (B) 3-mono-tert-butyl-4hydroxytoluene (MBHT). (C) 35-di-tert-butyl-4-hydroxyanisole (DBHA) and (D) 3-tert-butyl-4hydroxyanisole (3-BHA). 


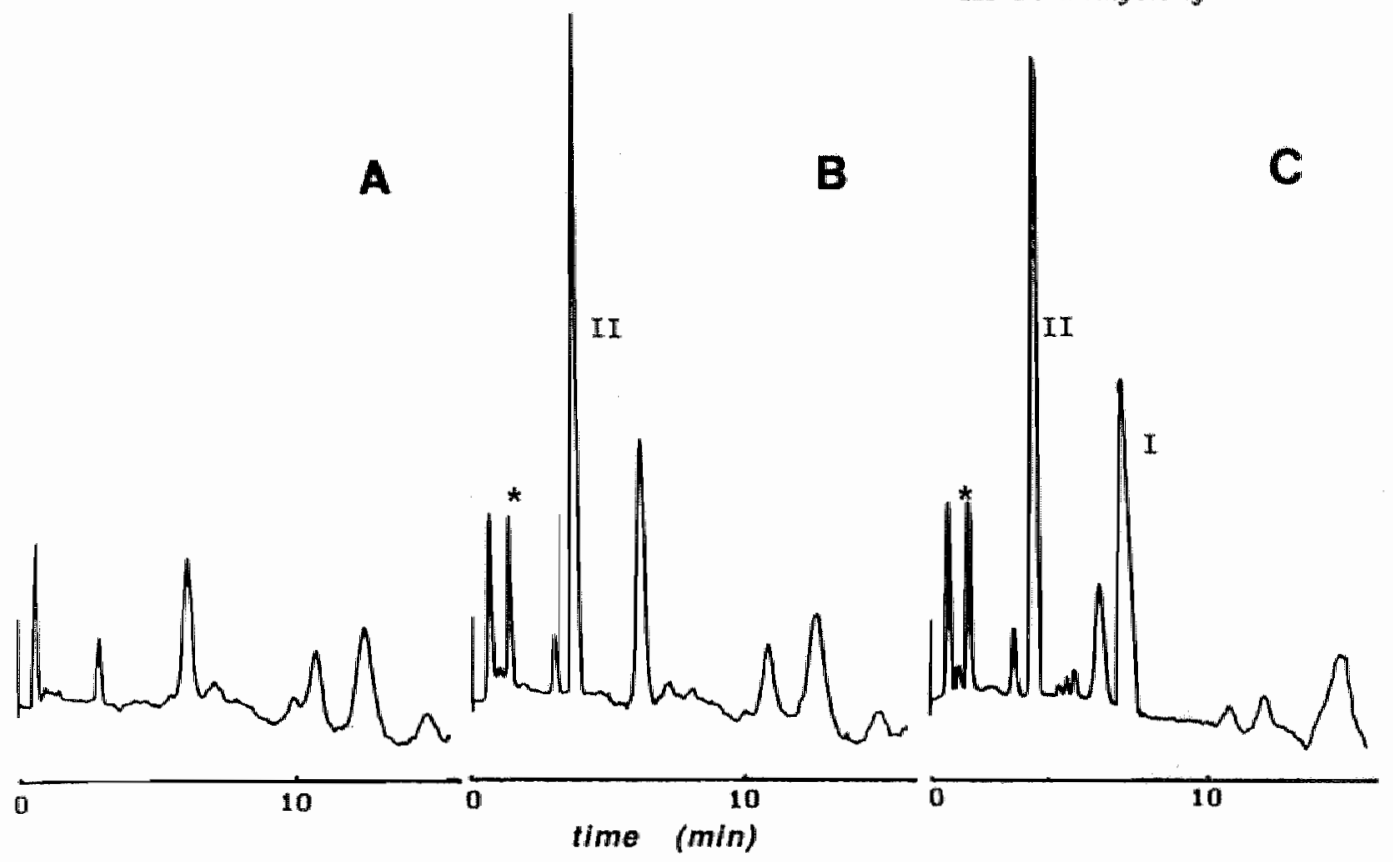

Figure 3-2: Chromalograms for the assay of BUT in plasma using DBHA as an internal standard. The dealkylated products $M B H T$ (I) and BHA (II) are indicated. (A) Extract of $1 \mathrm{ml}$ blank plasma; (B) Extract of I ml blank plasma with internal standard; asterisk indicates an unidentiffed product formed out of DBHA during the assay-procedure; (C) Extract of $200 \mathrm{pul}$ rat plasma containing $3.1 \mu \mathrm{g} / \mathrm{ml}$ BITT. Chromatograms were recorded using a programmable fluorescence detector set at $0.050 \mathrm{AU}$ between 0 and 5 min and al 0.010 AU between 5 and 15 min. Auto-zeros were given at $t=0$ and $t=5 \mathrm{~min}$.

\section{Results and discussion}

Extraction and chromatography

A few methods for the determination of BHT in plasma or serum have been reported. However, only one HPLC-procedure is available (17), which uses gradient elution and UVdetection, with a limit of detection of about $100 \mathrm{ng} / \mathrm{ml}$ serum. We have tried to develop a more sensitive HPLC-method, using an isocratic elution system. As already reported for BHA (18), phenolic antioxidants, due to their volatility, may be lost during sample preparation. In our experience, BHT and especially MBHT are much more volatile than BHA and DBHA. Therefore it was not only necessary to perform the evapourations of the extracting solvent at $0^{\circ} \mathrm{C}$, but also to add a little oil. BHT itself has no fluorescent properties (19), unlike the dealkylated product MBHT. Therefore, we modified the procedure of Mizutani and Ohe (20). BHT and DBHA were de-alkylated to their mono-butyl counterparts MBHT and 3-BHA, respectively, using concentrated hydrochloric acid.

The retention times of BHA and MBHT were 3.6 and $7.0 \mathrm{~min}$, respectively. The total run time was 15 min. Typical chromatograms are shown in Fig. 3-2. Blank plasma extracts (Fig. 3-2A) only revealed a small peak at the MBHT location, independent of the amount of plasma analyzed. This probably originated from some unknown impurity introduced during the procedure. Therefore, the practical limit of detection is about $20 \mathrm{ng}$ BHT per ml plasma (1 ml samples) or $4 \mathrm{ng}$ absolute per injection. Calibration graphs, calculated from peak- 
height ratios, were linear over the range $0-500 \mathrm{ng} / \mathrm{ml}$ BHT $(\mathrm{y}=0.00152 \mathrm{x}+0.030, \mathrm{r}=$ $0.9952, \mathrm{n}=3)$ and $0.5000 \mathrm{ng} / \mathrm{ml} \mathrm{BHT}(\mathrm{y}=0.00130 \mathrm{x}+0.060, \mathrm{r}=0.9964, \mathrm{n}=3)$. The absolute recovery of BHT on a mollar basis after extractions and transformation into MBHT is shown in Table 3-I. The absolute recovery of DBHA as BHA on a molar basis was $56 \pm$ $3 \%$ (mean \pm SD). Upon treatment with concentrated hydrochloric acid in methanol, BHA and at least one unidentified product, indicated by the asterisk in Fig. 3-2, were formed out of DBHA. This may be an explanation for the relatively low, but reproducible recovery of $\mathrm{DBHA}$ in our procedure. However, the recovery of the internal standard proved to be constant over a broad concentration range (results not shown). The variability of the assay is shown in Table I. These results are better than or comparable with other reported methods involving radioactivity, GC, GC-MS or HPLC (12-16).

TABLE 3-I: REPRODUCIBILITY OF THE DETERMINATION OF BHT IN PLASMA SAMPLES SPIKED AT THREE DIFFERENT CONCENTRATIONS

\begin{tabular}{llllll}
\hline $\begin{array}{l}\text { Added } \\
\text { concentration } \\
(\mathrm{ng} / \mathrm{ml})\end{array}$ & $\mathrm{n}$ & $\begin{array}{l}\text { Measured } \\
\text { concentration } \\
(\mathrm{ng} / \mathrm{ml})\end{array}$ & $\begin{array}{l}\text { Coefficient } \\
\text { of variation } \\
(\%)\end{array}$ & $\begin{array}{l}\text { Accuracy } \\
(\%)\end{array}$ & \multicolumn{1}{l}{$\begin{array}{l}\text { Recovery } \\
(\%)\end{array}$} \\
\hline 50 & 3 & $51 \pm 4^{*}$ & 7 & $102 \pm 7$ & $100 \pm 10$ \\
500 & 3 & $460 \pm 10$ & 2 & $92 \pm 2$ & $75 \pm 1$ \\
5000 & 3 & $5106 \pm 187$ & 4 & $102 \pm 4$ & $70 \pm 2$ \\
\hline
\end{tabular}

* Values represent the mean $\pm S D$.

Animal experiments

Concentration versus time curves for $\mathrm{BHT}$ in the plasma of two rats after oral administration are presented in Fig. 3-3. A peak concentration of about $3 \mu \mathrm{g} / \mathrm{ml}$ was observed after 2-3 hours. These preliminary data are not in agreement with the results of Rao and Wong (15), who found plasma concentrations peaking between 250 and $450 \mu \mathrm{g} / \mathrm{ml}$ in a similar experiment. In another experiment with $\mathrm{BHA}$ instead of $\mathrm{BHT}$, we showed that peak concentrations of $\mathrm{BHA}$ in plasma were between 0.2 and $1.0 \mu \mathrm{g} / \mathrm{ml}(18)$, which indicates that BHT is more rapidly absorbed from the gastro-intestinal tract and/or more slowly cleared from plasma, as compared to BHA. Detailed toxicokinetic studies of BHT in the rat are currently being undertaken.

\section{Acknowledgements}

Mr. B. Zwanenburg and Mr. K. Sekikawa are greatly acknowledged for helpful discussions. Mr. F. Weekers, Mr. E. van Dam and Mr. P. Schoffelen for excellent technical assistance, and Mrs. M. Peters for typing the manuscript. 


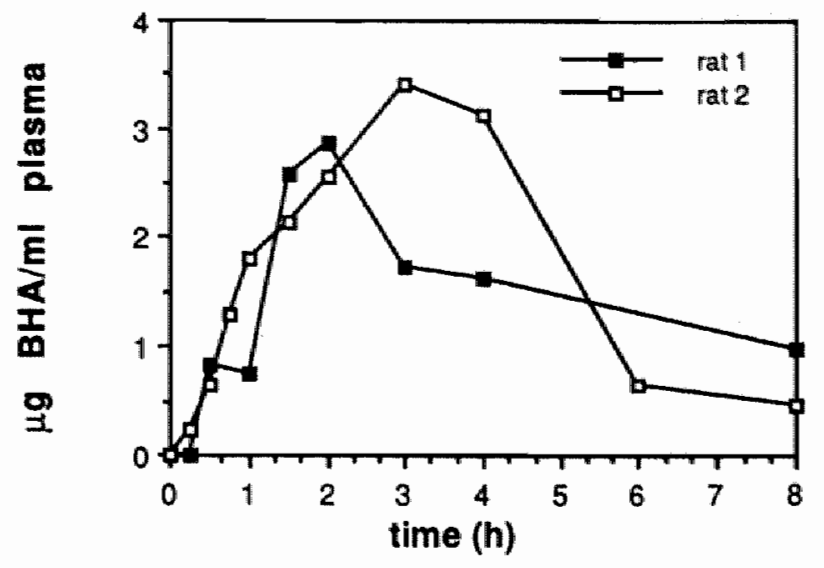

Figure 3-3: BHT concentrations in plasma of two rats sampled at various vimes after in gastro administration of $200 \mathrm{mg} / \mathrm{kg}$ BHT in corn oil.

\section{References}

1. R.J. Sims and J.A. Fioriti, in: T.E. Furia (Ed.), CRC Handbook of food additives, Vol. II, Chemical Rubber Co., Boca Raton, Fl, 2nd Ed, 1980, p. 13.

2. A.M. Malkinson, Environm. Mutagen. 5 (1983) 353.

3. H. Babich, Environm. Res., 29 (1982) 1.

4. M. Hirose, M. Shibata, A. Hagiwara, K. Imaida and N. Ito. Fd. Cosmet. Toxicol. 19 (1981) 147.

5. Y. Nakagawa, K. Tayama, T. Nakao and K. Hiraga. Biochem. Pharmacol, 33 (1984) 2669.

6. A.A. Marino and J.T. Mitchell. Proc. Soc. Exp. Biol. Med. 140 (1972) 122.

7. O. Takahashi and K. Hiraga. Acta Pharmacol. Toxicoll. 49 (1981) 14.

8. N. Ito, S. Fukushima and H. Tsuda, CRC Crit. Rev, Toxicol. 15 (1985) 109.

9. R. Kahl, J. Enwiron Sci. Health, C4 (1) (1986) 47.

10. M. Hirose, A. Masuda, Y. Kurata, E. Ikawa, Y. Mera, and N. Ito. J.Natl.Cancer Inst. 76 (1986) 143.

11. R.C. Lindenschmidt, A.F. Tryka, M.E. Goad, and H.P. Witschi. Toxicology 38 (1986) 151.

12. P. Olsen, O. Meyer, N. Bille and G. Würzen, Food Chem. Toxicol. 24 (1986) 1.

13. M. Matsuo, K. Mihara, M. Okuno, H. Ohkawa and J. Miyamoto. Food Chem. Toxicol. 22 (1984) 345.

14. R. El-Rashidy and S. Niazi. J. Pharm.Sci. 69 (1980) 1455.

15. A.V. Rao and G.K.K. Wong. Drug-Nutr. Interaction 2 (1983) 69.

16. L.1. Wiebe, J.R. Mercer and A.J. Ryan. Drug Metab.Disp. 6 (1978) 296.

17. J. Terao, R.A. Magarian, G. Brueggemann and M.M. King. Anal. Biochem. 151 (1985) 445.

18. H. Verhagen, H.H.W. Thijssen and J.C.S. Kleinjans. J. Chromatogr. 413 (1987) 282.

19. A.N. Masoud and Y. N. Cha. J. High Resolut. Chromatogr. Chromatogr. Commun. 5 (1982) 299.

20. T. Mizutani and T. Ohe. Eisei Kagaku 22 (1976) 260. 
Chapter 4

\title{
Rapid determination of isomer ratios of butylated hydroxyanisole by high-performance liquid chromatography
}

\author{
Hans Verhagen and Jos C.S. Kleinjans \\ Journal of Chromatography 464 (1989) 438-44l
}

\section{Introduction}

Butylated hydroxyanisole (BHA) is widely used as an antioxidant in food and cosmetic products. Commercially available BHA consists of two isomers (Fig. 4-1.): 3-tert-buty]-4hydroxyanisole (3-BHA, major isomer, $>85 \%$ ) and 2-tert-butyl-4-hydroxyanisole (2-BHA, minor isomer, <15\%). 3-BHA has the stronger antioxidant properties (1).

BHA is both an efficient inhibitor and promotor of chemically induced carcinogenesis $(2,3)$. 2-BHA is the more effective inhibitor of benzo[a]pyrene-induced forestomach neoplasia in mice (4). Further, BHA causes forestomach lesions, hyperplasia, papillomas and carcinomas in rodents after feeding of high levels in the diet $(3,5)$. This carcinogenic sction of BHA is largely attributable to 3-BHA, the main component; 2 BHA appears to be much less effective (5).

Therefore, in experiments with BHA its isomer ratio should be known. Also current pharmacopoeias require that the levels of 2-and 3-BHA in a batch be determined. We have previously reported a sensitive high-performance liquid chromatography (HPLC) method for measuring plasma BHA concentrations (6). That method made no distinction between 2 and 3-BHA, however, as both analytes had the same retention time. We now report a rapid and simple method for the determination of the isomer-ratio of $\mathrm{BHA}$ batches, applying normal-phase HPLC and UV or fluorescence detection, which is convenient with respect to simplicity, speed, collumn maintenance, precision and cost in comparison with other methods involving thin-layer chromatography $(7,8)$, gas chromatography $(8,9)$, HPl.. C $(8,10,11)$, column chromatography $(12)$, or non-chromatographic methods $(8,13)$.
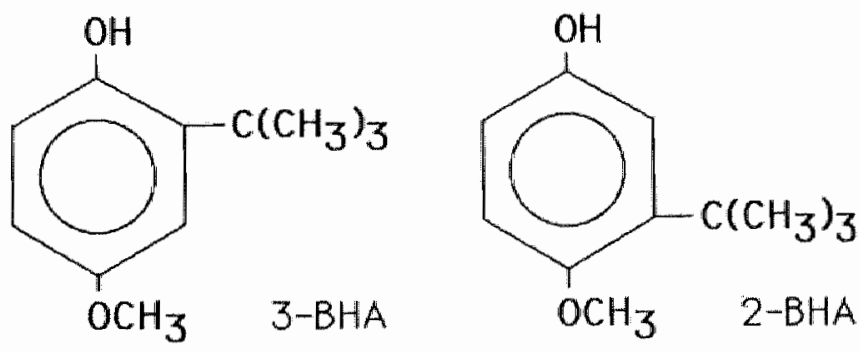

Figure 4-1: Structures of 3-BHA (major isomer, $>85 \%$ ) and 2-BHA (minor isomer, $<15 \%$ ), 


\section{Experimental}

Reference standards were a gift from Rhône-Poulenc (Dagenham, U.K.) and contained $85.3,88.8,91.5$ and 96.2 w of 3-BHA respectively (determined by infra-red spectroscopy (14)). Two batches of food-grade BHA were a gift from J. Dekker (Wormerveer. The Netherlands). One batch of BHA was purchased from Sigma (St. Louis, MO, U.S.A.). M-Heptane (Fisons, Loughborough, U.K.) and ethanol (Merck, Darmstadt, F.R.G.) wore of HPLC-grade.

Solutions of $100 \mu \mathrm{g} / \mathrm{mm}$ of 2 and 3-BHA were prepared in $n$-heptane and $20 \mu \mathrm{l}$ samples were injected onto a LiChrosorb \$i 60-5 column (250 × $4.6 \mathrm{~mm}$ I.D.) (Chrompack, Middelburg, The Netherlands). The mobile phase was $n$-heptane-ethanol $(400: 5 ; \mathrm{v} / \mathrm{v})$ at a flow-rate of $2.5 \mathrm{ml} / \mathrm{min}$. The effluent was monitored by a Kratos Spectroflow 980 programmable fuorescence detector set at $290 \mathrm{~nm}$ with a cut-off filter at $320 \mathrm{~nm}$ in series with a Kratos Spectroflow 783 programmable UV detector set at $290 \mathrm{~nm}$. For the determination of isomer ratios peak heights were measured in addition to peak areas (by cutting and weighing).

\section{Results and discussion}

Preliminary experiments indicated that a mixture of 2- and 3-BHA can be separated on a LiChrosorb 5 RP-18 column ( $150 \times 4.6 \mathrm{~mm}$ I.D.) and on a LiChrosorb RP-18 $10 \mathrm{~cm}$ cartridge column when eluted with methanol-water-acetic acid $(40: 59: 1, \mathrm{v} / \mathrm{v} / \mathrm{v})$ or an eluent of comparable strength with acetonitrile instead of methanol. These methods resulted in long retention times (up to 1 hour), however, and produced very asymmetric peaks, 3-BHA eluting before 2 -BHA.

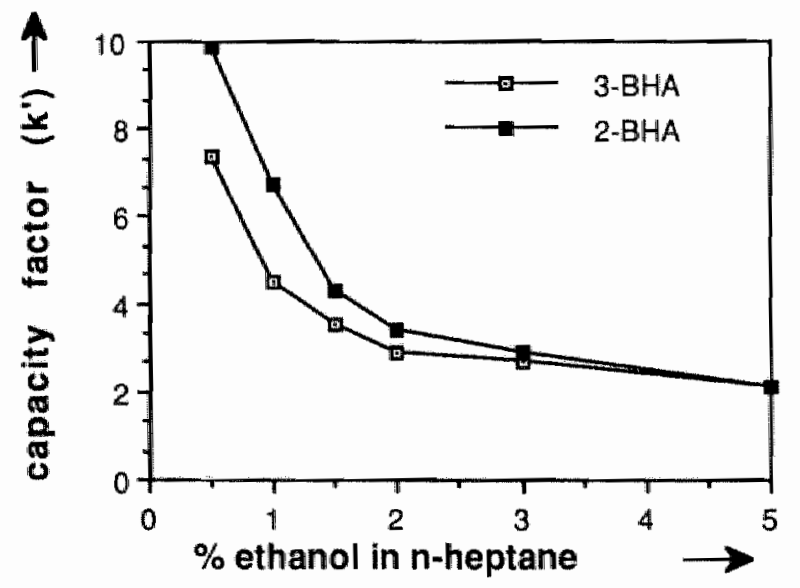

Figure 4-2: Effect of increasing concentrations of ethanol in $n$-heptane on the capacity factors $(k)$ of 2-BHA and 3-BHA.

Fast elution of separated isomers can be achieved, however, on a normal-phase LiChrosorb Si 60-5 column. Fig. 4-2 shows the effect of increasing concentrations of ethanol in $n$ heptane on the capacity factors $\left(k^{\prime}\right)$ of the BHA isomers. $1.25 \%$ Ethanol produced a fast and complete separation of isomers, with almost symmetrical peaks, within 11 minutes; 3BHA and 2-BHA elute after 8.9 and $10.3 \mathrm{~min}$, respectively. The limit of detection was about $0.5 \mathrm{ng}$ for either isomer. Typical chromatograms are shown in Fig. 4-3. 


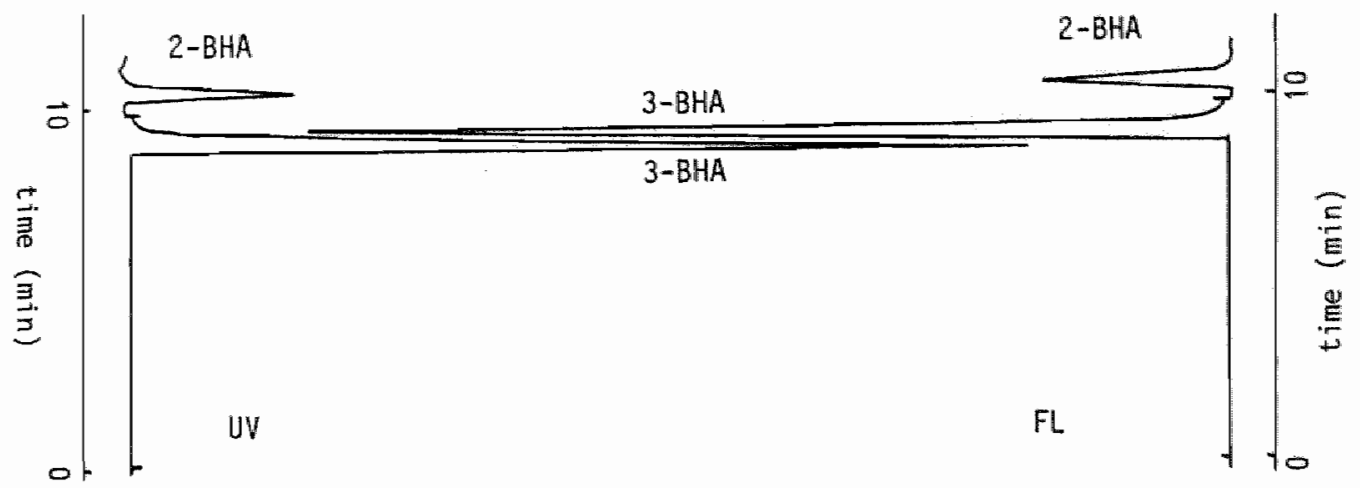

Figure 4-3: Typical chromatograms for the separation of 2- and 3-BHA on a LiChrosorb Si 60-5 column using n-heptane:ethanol (400:5). For UV detection (left) the range was set at 0.05 AUFS for $0-9.5$ min and at 0.0I AUFS thereafter; for fluorescence detection (right) the sevtings were 0.25 and 0.05 AUFS. respectively.

TABLE 4-I DETERMINATION OF ISOMER RATIOS OF 2-BHA AND 3-BHA IN DIFFERENT BATCHES

\begin{tabular}{llllll}
\hline batch $^{\mathrm{a}}$ & \multicolumn{2}{l}{$\begin{array}{l}\text { Peak-areamethod } \\
\text { UV } \\
\text { detcetion }\end{array}$} & $\begin{array}{l}\text { Fluorescence } \\
\text { detection }\end{array}$ & $\begin{array}{l}\text { Peak-heigh mothos } \\
\text { UV } \\
\text { detoction }\end{array}$ & $\begin{array}{l}\text { Fluorescence } \\
\text { detection }\end{array}$ \\
\hline RP $(85.3 \%)$ & $85.8 \pm 0.5 \% \mathrm{~b}$ & $85.4 \pm 0.5 \%$ & $87.4 \pm 0.2 \%$ & $86.8 \pm 0.2 \%$ \\
RP $(88.8 \%)$ & $90.0 \pm 0.2 \%$ & $89.7 \pm 0.2 \%$ & $9 \| .3 \pm 0.1 \%$ & $90.8 \pm 0.1 \%$ \\
RP $(91.5 \%)$ & $91.8 \pm 0.3 \%$ & $91.5 \pm 0.3 \%$ & $92.9 \pm 0.1 \%$ & $92.5 \pm 0.1 \%$ \\
RP $(96.2 \%)$ & $96.2 \pm 0.2 \%$ & $96.0 \pm 0.1 \%$ & $96.7 \pm 0.1 \%$ & $96.5 \pm 0.0 \%$ \\
FG I & $86.9 \pm 0.3 \%$ & $86.5 \pm 0.2 \%$ & $88.4 \pm 0.1 \%$ & $87.8 \pm 0.2 \%$ \\
FG II & $93.6 \pm 0.3 \%$ & $93.0 \pm 0.2 \%$ & $94.2 \pm 0.1 \%$ & $93.8 \pm 0.1 \%$ \\
S & $95.8 \pm 0.2 \%$ & $95.5 \pm 0.1 \%$ & $96.3 \pm 0.1 \%$ & $96.1 \pm 0.1 \%$ \\
\hline
\end{tabular}

a: Isomer ratios are cxpressed in terms of the percentage 3-BHA (Mean \pm SD).

b: RP, sample of Rhône-Poulene containing known isomer ratios; FG: food-grade sample; S, commercially oblaincd sample. 
Table 4-1 gives the results of the determination of isomer ratios of 2- and 3-BHA in several batches. Determinations based on peak area measurement after UV or fluorescence detection gives a reliable index of isomer ratios, as the values determined are in close agreement with those already known. Determinations based on peak heights give poorer results. The cofficients of variation (CV) for the peak-area and peak-height methods were $0.3 \%$ and 0.1 \% respectively, with no difference between UV and fluorescence detection. The larger CV of the peak-area method may be due to the weighing method.

In conclusion, 2- and 3-BHA are easily separated on a LiChrosorb Si $60-5$ column using $1.25 \%$ ethanol in $n$-heptane as the eluent. The isomer ratios are determined by measuring perak areas based on UV or fluorescence detection.

\section{References}

1. G.E. Penketh. J. Appl. Chem. 7 (1957) 512.

2. Anonymous. IARC Monographs on the evaluation of the cancinogenic risk of chemicalls to humans. 40 (1986) 123.

3. N. Ito, S. Fukushima and H. Tsuda. CRC Crit. Rev. Toxicol. 15 (1985) 109.

4. L.K.T. Lam, R.P. Pai and L.W. Watuenberg. J. Med. Chem. 22 (1979) 569.

5. N. Ito, M. Hirose, Y. Kurata, E. lkawa, Y. and S. Fukushima. Gann 75 (1984) 471 .

6. H. Verhagen, H.H.W. Thijssen and J.C.S. Kleinjans. J. Chromatogr. 413 (1987) 282.

7. M.R. Sahasrabudhe. J. Assoc. Offic. Anal. Chem. 47 (1964) 888.

8. M. Prosek, M. Katic, D. Milivojevic and M. Bano. J. High Resolut. Chromatogr. Chromatogr. Commun. 3 (1980) 652

9. G.A.S. Ansari. J. Chromatogr. 291 (1984) 421

10. G.A.S. Ansari. J. Chromatogr. 262 (1983) 393

11. J.C. Berridge, J. Kent and K.M. Norcott. I. Chromatogr. 285 (1984) 389

12. P. Kauffman. J. Chromatogr. 132 (1977) 356

13. M.J. De Long, H.J. Prochaska and P. Talalay. Cancer Res. 45 (1985) 546

14. P.P. Coppen, personal communication. 
PART II

METABOLISM AND KINETICS OF BHA AND BHT IN MAN AND RAT 



\author{
Chapter 5 \\ Disposition of single oral doses of \\ butylated hydroxyanisole in man and rat
}

Hans Verhagen, Henk H.W. Thijssen, Foppe ten Hoor and Jos C.s. Kleinjans

Food and Chemical Toxicology 27 (1989) 151-158

\begin{abstract}
The kinetics and metabolism of butylated hydroxyanisole (BHA) have been compared between man and rats. Oral doses of 2,20 or $200 \mathrm{mg} B H A / k g$ body weight were administered to male Wistar rats and a single oral dose of $0.5 \mathrm{mg} / \mathrm{kg}$ body weight was administered to human volunteers (non-smoking males). Following oral administration of 2 or $20 \mathrm{mg} \mathrm{BHA} / \mathrm{kg}$ body weight to rats no plasma BHA profiles were observed, whereas at the $200 \mathrm{mg} \mathrm{BHA} / \mathrm{kg}$ body weight dose level plasma BHA peak concentrations between 100 and $400 \mathrm{ng} / \mathrm{ml}$ were detected. Plasma BHA peak levels and the area under the curve show that the application of $15 \%$ polyethylene glycol-400 as the vehicle produced significantly lower values compared with those obtained using the vehicles, salad dressing, corn 'oil and dimethylsulphoxide. In man, oral administration of $0.5 \mathrm{mg} \mathrm{BHA} / \mathrm{kg}$ body weight dissolved in corn oil gave plasma BHA peak concentrations of greater value than $100 \mathrm{ng} / \mathrm{ml}$ (range 53 to $255 \mathrm{ng} / \mathrm{ml}$ ). In rats, $24 \mathrm{~h}$ after dosing 2,20 or $200 \mathrm{mg} \mathrm{BHA} / \mathrm{kg}$ body weight the mean BHA concentrations in adipose tissue ranged from 0.7 to $6.8 \mu \mathrm{g} / \mathrm{g}$. In man and rats, BHA was 0 -demethylated to tertbutylhydroquinone (TBHQ). This is the first study to report that TBHQ is an in vivo metabolite of BHA in rats. Within 4 days following oral administration the total recovery of BHA in the urine and feces of man $(0.5$ $\mathrm{mg} \mathrm{BHA} / \mathrm{kg}$ body weight) and rats $(200 \mathrm{mg}$ BHA/kg body weight) was $49 \pm$ $7 \%$ and $95 \pm 10 \%$ (mean \pm SD) respectively. In rats, BHA was excreted in the urine as free BHA (2\%), conjugated BHA (48\%) and conjugated TBHQ (9\%) and in the feces as free BHA (36\%). In man, BHA was excreted in the urine mainly as conjugated BHA $(39 \%)$ together with smaller amounts of conjugated TBHQ $(9 \%)$; no free BHA was found in the urine or feces. In man and rats only the fraction of BHA excreted in urine as conjugates of BHA and TBHQ was qualitatively and quantitatively comparable. Results in this study indicate a considerable difference in the biological fate of BHA following oral administration of high and low doses of BHA in rat and man, respectively.
\end{abstract}




\section{Introduction}

Butylated hydroxyanisole [2(3)-tert-butyl-4-hydroxyanisole] (BHA) (CAS no. 25013-165) and butylated hydroxytoluene [3-5-di-tert-butyl-4-hydroxytoluene] (BHT) (CAS no. 128-37-0), sterically hindered phenolic compounds, have widespread use as antioxidants in the human diet (Sims \& Fioriti, 1980). Their use as food additives has been Generally Recognized As Safe, especially since they appeared to be potent inhibitors of chemically induced mutagenicity and carcinogenicity in vitro and in vivo (Wattenberg, 1980 and 1985).

Recent studies however, indicate that BHA, BHT and other antioxidants give rise to tumor inducing effects (Ito et al., 1985; Anonymous, 1984; Kahl, 1984, 1986). In long-term feeding studies of rats fed $2 \%$ BHA in the diet, BHA acted as a carcinogen in the forestomach (Ito et al., 1983). Sequential changes are dose-dependent and involve the development of lesions, hyperplasia, papillomas and carcinomas (Abraham et al., 1986; Altmann et al., 1985; Ito et al ${ }_{\text {, }} 1983$ and 1985 and 1986; Iverson et al., 1985; Masui et al., 1986 Nera et al, 1984; Rodrigues et al., 1986). The effects of BHA administered orally at dose levels up to $2 \%$ in the diet are reproducible in hamsters and probably in mice (Masui et al., 1986). In a six month feeding study of dogs fed $1 \%$ BHA in the diet no tumor inducing effects were observed (Tobe et al, 1986). In pigs, however, oral administration of 200 or $400 \mathrm{mg}$ BHA/kg body weight for 110 days induced proliferative and parakeratotic changes of the oesophageal epithelium (Würtzen and Olsen, 1986). In primates, consumption of high doses of BHA (up to $500 \mathrm{mg} / \mathrm{kg}$ body weight) for 28 to 85 days increased the mitotic index in the distal oesophagus (Iverson et al., 1985), and produced liver hypertrophy (Allen and Engblom, 1972).

Safety evaluation of the consumption of BHA and BHT by man is difficult since results of carcinogenicity studies are often ambiguous. In view of these findings the Joint FAO/WHO Expert Committee on Food Additives (JECFA) (1986) lowered the acceptable daily intake (ADI) of BHA and BHT to $0-0.3 \mathrm{mg} / \mathrm{kg}$ body weight and $0-0.125 \mathrm{mg} / \mathrm{kg}$ body weight respectively (JECFA, 1986).

It has been suggested that health risk assessment based on the concept of dose should be replaced by that of effective concentration at the target tissue (Garattini 1986; Whittemore et al., 1986). Plasma concentrations are supposed to be a function of the concentrations reached in such tissues. It is of interest that following oral administration of $0.2-2.0 \mathrm{~g}$ BHA $/ \mathrm{kg}$ body weight to rats, plasma peak concentrations of $0.3-30 \mu \mathrm{g} \mathrm{BHA} / \mathrm{ml}$ were observed (Bailey et al., 1981; Guarna et al., 1983), whereas in man oral intake of 0.5 (Castelli et al., 1984) or 1.7 (El-Rashidy \& Niazi, 1979) mg BHA/kg body weight produced plasma-peak concentrations of 73-600 $\mathrm{ng} B \mathrm{BH} / \mathrm{ml}$, indicating interspecies differences in biological fate of BHA. These studies, however, did not involve parallel analyses of kinetics and metabolism of BHA in man and laboratory animals.

In this study we have examined the plasma kinetics, adipose tissue storage and in vivo metabolism of BHA, following oral administration of mid- and high-dose levels to rats and a single low dose to man. In addition, since BHA may be ingested by man from a variety of food products, the effects of different vehicles on the plasma kinetics of BHA in the rat were investigated. 


\section{Materials and methods}

\section{Chemicals}

For the animal experiments BHA (a mixture of isomers of greater than 99\% purity; the 3-BHA isomer forming $96.2 \%$ ) was obtained from Sigma Chemical Co. (St. Louis, MO, USA). For the human experiments food-grade BHA (a mixture of isomers, the 3-BHA isomer forming $94.4 \%$, of greater than $99 \%$ purity) was a generous gift from the J. Dekker Company (Wormerveer, The Netherlands). teri* Butylhydroquinone (TBHQ; CAS no. 1948-33-0) (greater than 97\% purity), 3,5-di-tert-butyl-4hydroxyanisole (DBHA) (greater than $97 \%$ purity) and trimethyllhydroquinone (MFQ) (greater than $97 \%$ purity) were purchased from the Aldrich Chemical Co., (Brussels, Belgium). B-Glucuronidase-arylsulfatase (EC 3.2.1.31/ EC 3.1.6.1) was obtained from Boehringer (Mannheim, FRG). High-performance liquid chromatography (HPLC)-grade methanol was obtained from Fisons Chemicals Ltd. (Loughborough, England). Water was purified using a Milli-Q water purification system. All other chemicals used throughout the studies were of analytical grade.

\section{Treatment of animals}

A catheter was inserted into the right femoral artery of 34 male Wistar rats $(250-350 \mathrm{~g}$; TNO, Zeist, The Netherlands) under ether anaesthesia in order to collect blood samples. After fasting overnight, the rats werc given by gavage a solution of $200 \mathrm{mg}$ BHA/kg body weight dissolved in corn oil (CO) $(\mathrm{n}=9)$, dimethylsulphoxide (DMSO) ( $\mathrm{n}=9$ ), salad dressing (SD) (Calve, Delft, The Netherlands) $(\mathrm{n}=9)$ or $15 \%$ polyethyiene glycol-400 in water (15\% PEG) $(\mathrm{m}=7)$ in which BHA forms a suspension. Further groups of rats received per os a dose of $20 \mathrm{mg} B H A / \mathrm{kg}$ body weight in $\mathrm{CO}(\mathrm{n}=4)$ or a dose of $2 \mathrm{mg}$ BHA/kg body weight in either $\mathrm{CO}(\mathrm{n}=2)$ or $10 \%$ ethanol $(\mathrm{n}=2)$. In all instances a volume of $1 \mathrm{ml}$ solution per $\mathrm{kg}$ body weight was administered. Blood samples $(200-250 \mu \mathrm{l})$ were taken at $0,10,20,30,50,70,90,120,180,240$ and $360 \mathrm{~min}$ after oral BHA administration and collected in heparinized vessels. In order to protect the animals from anaemia, washed blood cells $(0.5 \mathrm{ml})$ diluted with $0.9 \% \mathrm{NaCl}(0.5 \mathrm{ml})$, were re-administered after the 120-min sample. Food access was allowed after $6 \mathrm{~h}$. After $24 \mathrm{~h}$ rats were killed by exsanguination under ether anaesthesia. Plasma and mesenteric abdominal fat were stored at $-20{ }^{\circ} \mathrm{C}$.

Cannulation of the right femoral artery and vein of four rats was performed in order to determine plasma BHA kinetics following intravenous (iv) administration. After fasting overnight, the rats were injected (iv) with a solution $(1 \mathrm{ml} / \mathrm{kg}$ body weight) of $5 \mathrm{mg} / \mathrm{ml} \mathrm{BHA}$ in polyethyleneglycoll $400(\mathrm{PEG})-0.9 \% \mathrm{NaCl}(1: 1 ; \mathrm{v} / \mathrm{v})$. Blood samples were taken at $0,1,2,4,8,16,30,45,60,90,120,240,360$ min and 24 h after BHA administration with the method described above. Access to food was allowed after $6 \mathrm{lt}$.

For the metabolism experiments the rats $(n=6)$ were individually housed in metabolism cages. Afler fasting overnight they received by gawage a solution ( $1 \mathrm{ml} / \mathrm{kg}$ body weight of $200 \mathrm{mg} \mathrm{BHA} / \mathrm{ml}$ in $\mathrm{CO}$. Urine and feces were subsequently collected daily for 4 days.

Treatment of human volunteers

Nine healthy, non-smoking male wolunteers $(32 \pm 5 \mathrm{yr}$ old; $74 \pm 4 \mathrm{~kg}$ ) were recruited from laboratory personnell. After fasting overnight, they ingested a gelatin capsule containing $0.5 \mathrm{mg}$ BHA/kg body weight as a solution of $10 \%$ BHA in CO. Blood samples $(5 \mathrm{ml})$ were taken from a catheter in an arm vein at 0.15 , $30,45,60,75,90,120,180,240$ and $300 \mathrm{~min}$ after administration and collected in heparinized vessels. Eating was permitted after $90 \mathrm{~min}$. Urine and feces were collected for a period of 4 days. The feces were homogenized, and together with samples of urine and plasma were stored at $-20^{\circ} \mathrm{C}$.

\section{Human adipose tissue}

Samples of human subcutancous fat from other subjects (up to $5 \mathrm{~g}$ ) (n=19) were collected in the course of abdominal surgery in the Maastricht Academic Hospital for the determination of background BHA lcvels in adipose tissue.

\section{High-performance liquid chromatography}

The HPLC system consisted of a Kratos Spectroflow 400 pump and a Kratos Spectroflow 980 programmable fluorescence detector with an excitation wavelength of $290 \mathrm{~nm}$ and a cul-off filter at $320 \mathrm{~nm}$. Injections were performed using a $20 \mu$ ll sample loop of Rheodyne 7125 syringe loading sample injector. HPLC analyses involved a LiChrosorb 5-RP-18 column (150 $\times 4.6 \mathrm{~mm}$ ID) in combination with a guard column (ODS pellicular matcrial) (Chrompack, Middelburg. The Netherlands). Mobile phases, all isocratic, consisted of 
mixtures of methanol, water and acetic acid and were recycled after elution. Methods are modified from Archer (1981).

Analyses of plasma BHA concentrations

These were performed as described previously by Verhagen et al. (1987). This method involwes extraction of BHA using diethyl ether and reverse-phase HPLC with fluorescence detection. The limit of detection was 50 $\mathrm{ng} / \mathrm{ml}$ for rat plasma $(100 \mu \mathrm{l})$ and $5 \mathrm{ng} / \mathrm{ml}$ for human plasma $(500 \mu \mathrm{l})$.

\section{Determination of free and conjugated BHA in urine}

Aliquots of urine (100-500 $\mu 1)$, with or without B-glucuronidase-arylsulfatase $(50 \mu l)$, were diluted to a total volume of $1 \mathrm{ml}$ with $1 \mathrm{M}$-sodium-acetate buffer $(\mathrm{pH} 4.8)$ and incubated overnight at $37^{\circ} \mathrm{C}$ in screw-capped vessels. TBHQ $(100 \mu \mathrm{g})$ in methanol was added as an intemal standard. Samples were then extracted with diethyl ether and after centrifugation the organic phase was evaporated to dryness at $0{ }^{\circ} \mathrm{C}$ under $\mathrm{N}_{2}$. Dried extracts: were dissolved in eluting solvent $(450 \mathrm{H})$ and chromatography was performed with methanol-wateracetic acid $(55: 44: 1, \mathrm{v} / \mathrm{v} / \mathrm{v})$ at a flow rate of $1.6 \mathrm{ml} / \mathrm{min}$. TBHQ and BHA were eluted after 1.9 and $5.2 \mathrm{~min}$, respectively. The limit of detection was about 0.1-0.2 $\mu \mathrm{g}$ BHA/ml urine. The concentration of the internal standard was unaffected by TBHQ formed as a metabolite of BHA, since measured concentrations of the metabolite are at least a hundred times less than those of the standard. In addition, authentic TBHQ will be almost entirely lost as a result of aerial oxidation during incubation ovemight.

\section{Determination of free and conjugated TBHQ in urine}

Aliquots of urine $(100-500 \mu \mathrm{l})$, with or without B-glucuronidase-arylsulfatase $(50 \mu \mathrm{l})$, were dilutued to a total volume of $1 \mathrm{ml}$ with $1 \mathrm{M}$-sodium-acetate buffer (pH 4.8). A solution of $1 \%$ ascorbic acid-1\% EDTA (100 $\mu l)$ in water was then added. MHQ (250 $\mu \mathrm{g})$ in methanol was added as an internal standard. Samples were saturated with $\mathrm{N}_{2}$ to prevent aerial oxidation of the analytes. After incubation owernight at $37^{\circ} \mathrm{C}$, samples were extracted with diethyl ether. The organic phase was washed with $5 \% \mathrm{NaHCO}_{3}$, centrifuged and evaporated to dryness at $0^{\circ} \mathrm{C}$ under $\mathrm{N}_{2}$. The dried extracts were dissolved in eluting solvent $(450 \mu \mathrm{l})$ containing $0.1 \%$ ascorbic acid and kept under $\mathrm{N}_{2}$. Chromatography with methanol-water-acetic acid $(42: 57: 1 ; \mathrm{v} / \mathrm{v} / \mathrm{v})$ at a flow rat of $1.6 \mathrm{ml} / \mathrm{min}$ eluted MHQ and TBHQ after 2.5 and $7.0 \mathrm{~min}$, respectively. Interference from small peaks gave rise to a limit of detection of $1 \mu \mathrm{g} \mathrm{TBHQ} / \mathrm{ml}$ urine.

Determination of BHA in feces and adipose tissue

Feces or adipose tissue (up to $10 \mathrm{~g}$ ) were homogenized with dry $\mathrm{Na}_{2} \mathrm{SO}_{4}(30 \mathrm{~g}$ ) using a mortar and a pestle. Corn oil $(0.1 \mathrm{~g})$ containing $1000 \mu \mathrm{g} / \mathrm{g}$ DBHA $/ \mathrm{g}$ feces or adipose tissue was added as an internal standard. The mixture was then extracted overnight in a Soxhlet apparatus (Pujol Forn, 1980) with light petroleum (Merck, Darmstadt, FRG). Equivalents of fat or feces $(0.5 \mathrm{~g})$ were dried under $\mathrm{N}_{2}$. The oily residue was extracted $(x 5)$ with methanol $(\mathbb{m l})$. An excess of lipid material was then removed by cooling on ice and centrifugation. HPLC analyses were performed as described for plasma BHA. The limit of detection was about $0.1-0.2 \mu \mathrm{g} \mathrm{BHA} / \mathrm{g}$ for adipose tissue and human feces and $1 \mu \mathrm{g} / \mathrm{g}$ for rat feces.

\section{Statistics.}

For all determinations good linear relationships were found $(0.98<\mathrm{r}<1.00$. generally $0.99<\mathrm{r}<1.00)$ in the appropriate ranges for $\mathrm{BHA}$ and TBHQ levels in plasma, urine, feces and adipose tissue. Recovery of analytes was always $90 \%$ or better. All determinations were performed in duplicate except for plasma BHA concentrations in rats, which were single determinations due to the small amounts of plasma available. Student's t-lest for unpaired values was used to assess statistical differences. $P<0.05$ was considered to be signilicant. 


\section{Results}

Animal experiments

Mean plasma BHA concentration-time profiles of rats dosed orally with $200 \mathrm{mg} \mathrm{BHA} / \mathrm{kg}$ body weight dissolved in different vehicles are shown in Fig. 5-1. In general, maximum plasma BHA-concentrations were seen within 30 min. Using $15 \% \mathrm{PEG}$ as the vehicle, plasma BHA peak concentrations were significantly $(p<0.05)$ lower than those observed when DMSO or CO were used. A 'dip' in the plasma concentration-time curves was observed at about $90 \mathrm{~min}$. From the individual plasma profiles, the area under the curve $(A U C)$ was determined for 0-360 min and 0-24 $\mathrm{h}$. Results show that application of $15 \%$ $\mathrm{PEG}$ as the vehicle produced significantly lower values than those obtained using other vehicles (Table 5-I). Some rats dosed orally with $20 \mathrm{BHA} / \mathrm{kg}$ body weight in CO showed a small plasma BHA peak in their chromatograms; no peaks were observed for rats dosed orally with $2 \mathrm{mg} \mathrm{BHA} / \mathrm{kg}$ body weight in either CO or $10 \%$ ethanol (data not shown).

TABLE 5-I: KINETIC PARAMETERS CALCULATED FROM INDIVIDUAL PLASMAPROFILES FOLLOWING ORAL ADMINISTRATTON IN RATS $200 \mathrm{mg}$ BHA/kg BODY WEIGHT DISSOL VED IN DIFFERENT VEHICLES.

\begin{tabular}{lllll}
\hline Kinetic parameter & DMSO & CO & SD & $15 \%$ PEG \\
\hline $\begin{array}{l}\text { Plasma peak } \\
\text { concentration } \\
\text { (ng BHA/ml plasma) }\end{array}$ & $408 \pm 381$ & $314 \pm 261$ & $226 \pm 173$ & $110 \pm 114^{\mathrm{a}}$ \\
$A U C_{0-6 \mathrm{~h}}(\mathrm{ng}$ *h/ml) & $823 \pm 503$ & $747 \pm 218$ & $611 \pm 506$ & $270 \pm 224^{\mathrm{b}}$ \\
$A U C_{0-24 \mathrm{~h}}(\mathrm{ng} / \mathrm{h} / \mathrm{ml})$ & $2020 \pm 1200$ & $1470 \pm 1510$ & $1440 \pm 790$ & $540 \pm 480^{\mathrm{c}}$ \\
\hline
\end{tabular}

a: Significantly lower than DMSO or CO $(\mathrm{P}<0.05)$;

b: Significantly lower than $\mathrm{DMSO}, \mathrm{CO}$ and $\mathrm{SD}(\mathrm{P}<0.005)$;

c: Significantly lower than DMSO $(\mathrm{P}<0.01), \mathrm{CO}(\mathrm{P}<0.05)$ or $\mathrm{SD}(\mathrm{P}<0.025)$.

Blood was sampled and plasma BHA concentrations were determined as described in Materials and Methods. AUCs were calculated by the trapezoidal method. Values represent the mean $\pm \mathrm{SD}$.

TABLE 5-II: KINETIC PARAMETERS CALCULATED FROM INDIVIDUAL PLASMA PROFILES FOLLOWING ADMINISTRATION (iv) OF $5 \mathrm{mg}$ BHA/kg BODY WEIGHT DISSOLVED IN PEG-0.9\% $\mathrm{NaCl}(1: 1, w / v)$.

Kinetic parameter

\begin{tabular}{lll}
\hline$A U C_{0-1 \mathrm{~h}}$ & $221 \pm 0.35$ & $\mathrm{ng} * \mathrm{~h} / \mathrm{ml}$ \\
$t 1 / 2$ & $14 \pm 2$ & $\mathrm{~min}$ \\
$V \mathrm{~d}$ & $2.8 \pm 0.9$ & 1 \\
$C L$ & $8.2 \pm 2.8$ & $1 / \mathrm{h}$
\end{tabular}

Blood was sampled and plasma BHA concentrations were determined as described in Materials and Mcthods. $A U C \mathrm{~s}$ were calculated by the trapezoidal method. Kinetic parameters were calculated according to the equations: $C L=D / A U C$ and $V d=\left[C L^{*}(1 / 2] / 0.693\right.$. Values represent the mean $\pm S D$. 

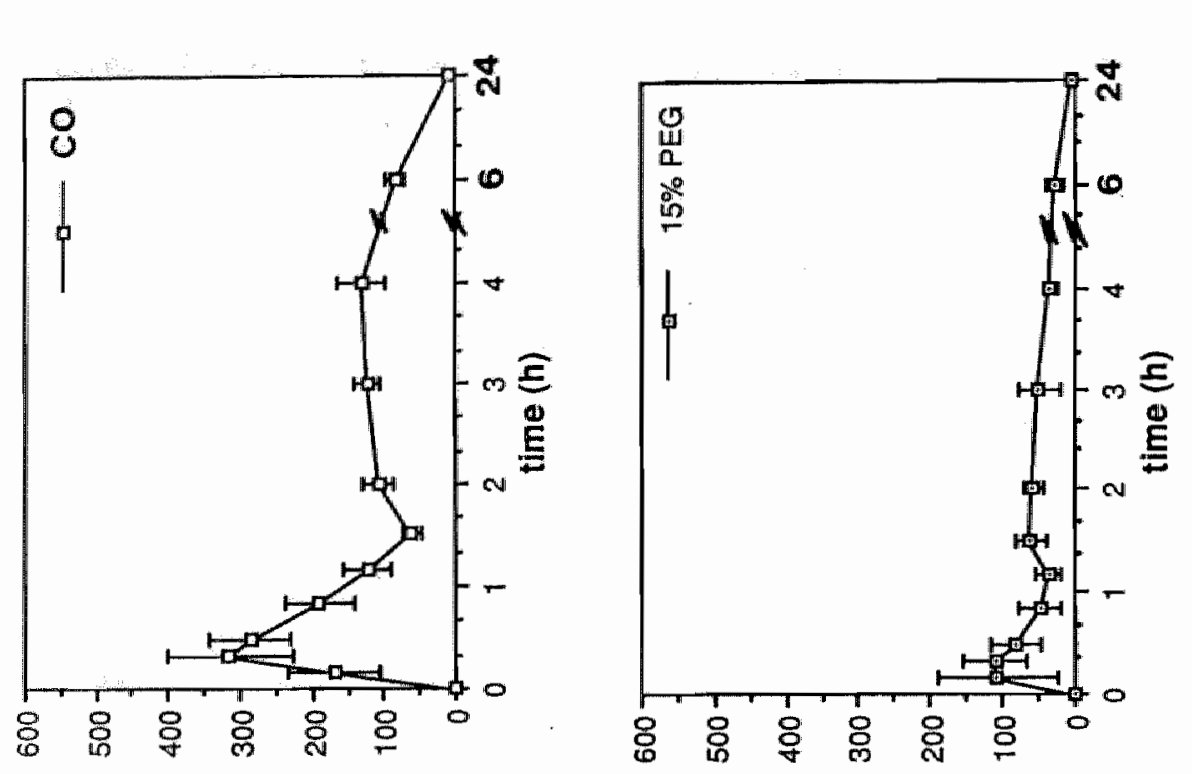

옥

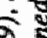

光

8 y

o

$\pm$

ㅇ.

5

5

2

5 a

$=$ t

년

z) 3

a

स

$\infty$

$\infty$

$8 \% 5$

त
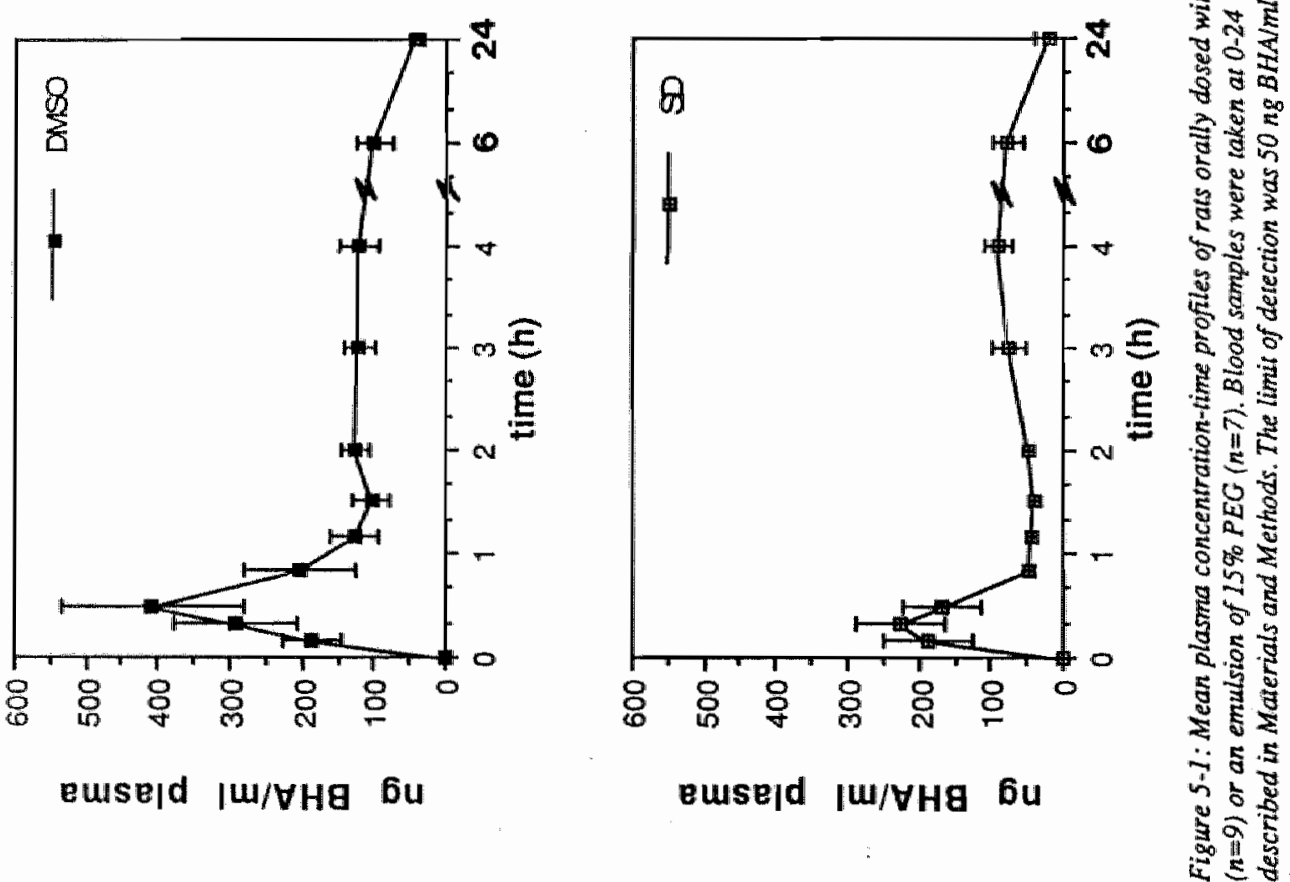

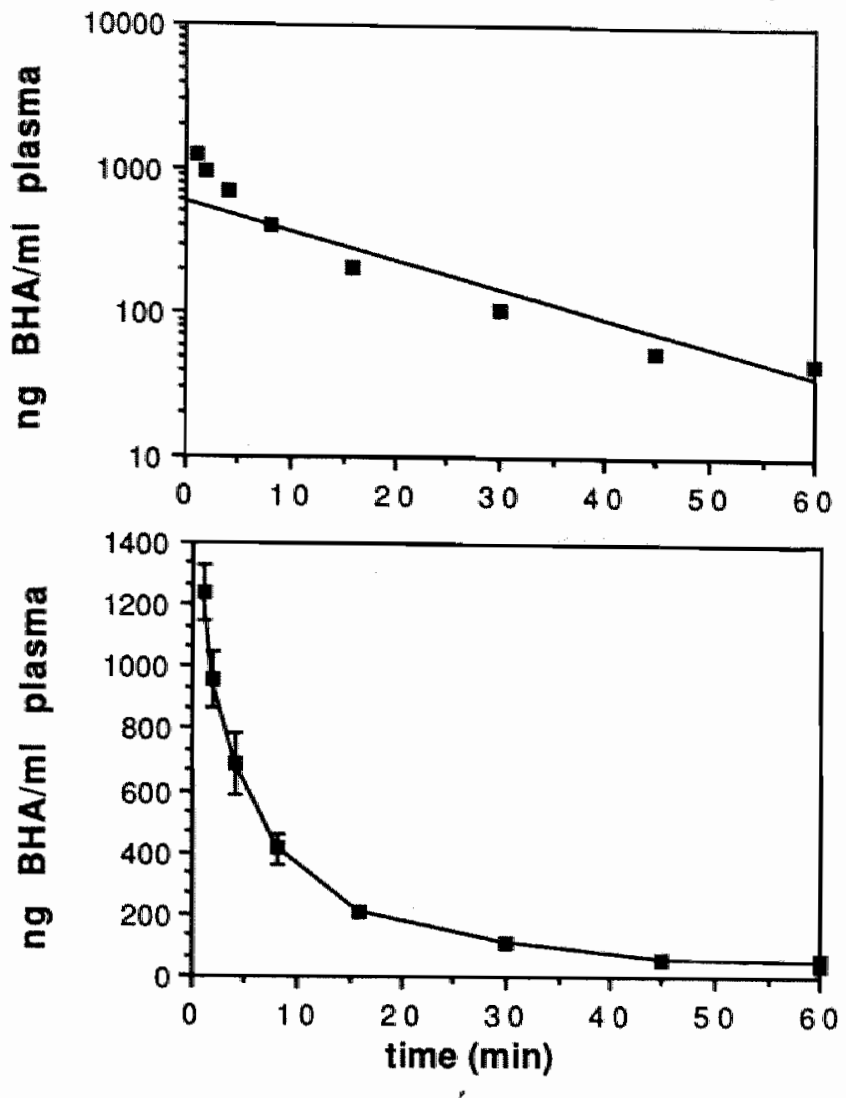

Figure 5-2: Mean plasma concentration-time profile of four rats injected (iv) with $5 \mathrm{mg} \mathrm{BHA/kg}$ body weight in PEG-0.9\% $\mathrm{NaCl}(I: I, v / v)$. Lower part: plasma concentrations vs time; mean $\pm S E$. Upper part: log plasma concentration vs time. Plasma BHA concentrations were determined as described in Materials and Merhods. The limit of detection was $50 \mathrm{ng}$ BHAlml plasma.

The mean plasma profile of rats injected (iv) with $5 \mathrm{mg} \mathrm{BHA} / \mathrm{kg}$ body weight dissolved in $\mathrm{PEG}-0.9 \% / \mathrm{NaCl}$ is shown in Fig. 5-2. A rapid decline in plasma BHA concentrations, reflecting the distribution phase, was seen within the first 5 min. Thereafter a $\log -\operatorname{linear}$ decrease in plasma BHA concentration was observed for up to $1 \mathrm{~h}$, after when the detection limit was reached. Assuming the plasma elimination phase to represent the steady-state. phase of elimination, kinetic parameters for BHA were estimated (Table 5-II).

Results of the determination of BHA and its demethylated form TBHQ in the urine and feces of rats are shown in Table 5-III. The majority of BHA and its metabolites (approximately $86 \%$ of the dose) were excreted within two days. In the urine small amounts of free $\mathrm{BHA}$, about $2 \%$ of the BHA dose, were determined but free TBHQ was not detected. Conjugated metabolites of BHA and TBHQ formed approximately $50 \%$ and $9 \%$, respectively, of the BHA dose. The feces were assayed for free BHA only; more than one third of the dose was excreted unchanged in the feces. Mean total recovery of oral BHA doses was $95 \pm 10 \%$ (mean $\pm \mathrm{SD}$ ). 
TABLE 5-III. DETERMINATION OF BHA AND ITS METABOLITES IN THE URINE AND FECES OF MAN AND RAT FOR 4 DAYS FOLLOWING ORAL ADMINISTRATION OF BHA.

\section{Day}

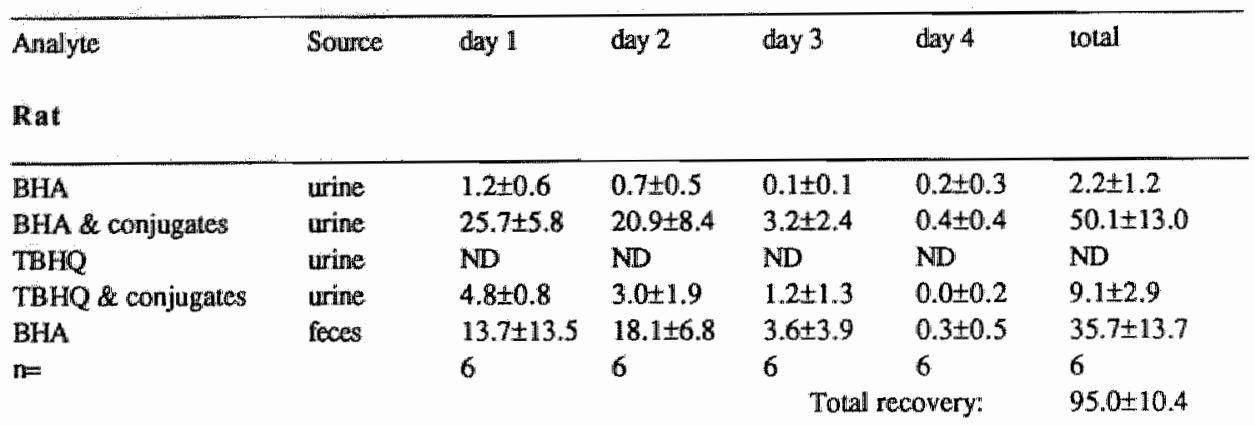

Man

\begin{tabular}{lllllll}
\hline BHA & urine & ND & ND & ND & ND & ND \\
BHA \& conjugates & urine & $36.9 \pm 5.2$ & $1.8 \pm 1.0$ & $0.5 \pm 0.5$ & $0.1 \pm 0.2$ & $39.2 \pm 4.8$ \\
TBHQ & urine & ND & ND & ND & ND & ND \\
TBHQ \& conjugates & urine & $8.9 \pm 3.5$ & $\mathrm{ND}$ & $\mathrm{ND}$ & $\mathrm{ND}$ & $8.9 \pm 3.5$ \\
BHA & feces & $\mathrm{ND}$ & $\mathrm{ND}$ & $\mathrm{ND}$ & $\mathrm{ND}$ & $\mathrm{ND}$ \\
$\mathrm{N}=$ & & 9 & 9 & 7 & 6 & - \\
& & & & & & \\
& & & & & &
\end{tabular}

a: Free BHA was occasionally detected in human urine just above the limit of detection.

The applied oral doses were $200 \mathrm{mg}$ BHA/kg body weight in CO in rats and $0.5 \mathrm{mg} \mathrm{BHA} / \mathrm{kg}$ body weight in $\mathrm{CO}$ in man. Urine and feces were analysed for $\mathrm{BHA}$ and metabolites according to procedures described in Materials and Methods. Values are expressed as a percentage of the dose. ND $=$ not detectable. Values represent the mean $\pm \mathrm{SD}$.

Minor amounts of BHA (mean: $3.4 \mu \mathrm{g} / \mathrm{g}$ ) were found in the abdominal fat of rats $24 \mathrm{~h}$ after oral administration (Table 5-IV). Rats administered $200 \mathrm{mg}$ BHA/kg body weight in DMSO showed significantly higher BHA levels in adipose tissue compared with those doses dissolved in $\mathrm{CO}(\mathrm{p}<0.01)$, SD $(\mathrm{p}<0.05)$ or $15 \%$ PEG $(\mathrm{p}<0.005)$. Unexpectedly, chromatograms of adipose tissue extracts of control rats contained a small peak co-eluting with BHA, which may represent BHA $(0.2 \mu \mathrm{g} / \mathrm{g})$ obtained from other sources (e.g. food).

Human experiments.

The mean plasma BHA concentration-time profile of man following oral administration of BHA is shown in Fig. 5-3. Maximal plasma BHA concentrations (range: $170-255 \mathrm{ng} / \mathrm{ml}$ ) were observed within 30-60 min in six volunteers. Plasma of three individuals showed BHA peaks (range: $53-81 \mathrm{ng} / \mathrm{ml}$ ) only after $90-120$ min. Kinetic parameters were calculated from individual data and are summarized in Table 5-V.

Concentrations of BHA, TBHQ and their conjugates in human excreta are given in Table 5III. Urinary excretion of the majority of metabolites occurred within $24 \mathrm{~h}$. A further $2-3 \%$ 
was excreted on days 2-4. Both BHA and TBHQ were excreted in the urine, mainlly as conjugates (about $39 \%$ of the dose) and only as conjugates (9\% of the dose), respectively. Free BHA was only occasionally detected in urine.

TABLE 5-IV. BHA CONCENTRATIONS IN ADIPOSE TISSUE OF RATS ADMINISTERED BHA.

\begin{tabular}{llll}
\hline Vehicle dose & $\begin{array}{l}\text { BHA } \\
\text { (mg BHA/kg } \\
\text { body weight) }\end{array}$ & $\begin{array}{l}\text { concentration } \\
(\mu \mathrm{g} / \mathrm{g})\end{array}$ & $\mathrm{n}$ \\
\hline DMSO & 200 & $6.8 \pm 2.7^{\mathrm{a}}$ & 8 \\
CO & 200 & $3.7 \pm 2.1$ & 11 \\
SD & 200 & $4.3 \pm 1.9$ & 8 \\
$15 \%$ PEG-400 & 200 & $2.4 \pm 1.3$ & 7 \\
CO & 20 & $0.7 \pm 0.5$ & 4 \\
CO & 2 & $1.5 \pm 0.2$ & 2 \\
$10 \%$ ethanol & 2 & $1.1 \pm 1.2$ & 2 \\
control & - & $0.2 \pm 0.1$ & 3
\end{tabular}

a: Significantly different from $\mathrm{CO}(\mathrm{P}<0.01), \mathrm{SD}(\mathrm{P}<0.05)$ and $15 \% \mathrm{PEG}(\mathrm{P}<0.005)$ in the high-dose group. Rats were dosed with 2,20 , or $200 \mathrm{mg}$ BHA/kg body weight in different vehicles. BHA concentrations in adipose tissue $24 \mathrm{~h}$ after oral administration were determined as described in Materials and Methods. Values represent the mean $\pm S D$.

In human feces BHA was not detected. Since the mean daily production of stool was $237 \pm$ $183 \mathrm{~g}$ (mean \pm SD) the limit of BHA detection was calculated as approximately $0.2 \%$ of the applied dose. Total recovery of BHA administered orally was $49 \pm 7 \%$ (mean \pm SD).

Nineteen samples of subcutaneous human adipose tissue, obtained from male and female patients aged between 25 and 74 years, were analysed for their background BHA content. None of the samples contained a detectable amount of BHA. The limit of detection was 0.1 $0.2 \mu \mathrm{g}$ BHA/g adipose tissue.

TABLE 5-V. KINETIC PARAMETERS CALCULATED FROM INDIVIDUAL PLASMA PROFILES FOLLOWING ORAL ADMINISTRATION OF $0.5 \mathrm{mg}$ BHA/kg BODY WEIGHT IN CO IN HUMAN VOLUNTEERS.

Kinetic parameter

\begin{tabular}{lll}
\hline Peak concentration & $117 \pm 75$ & $\mathrm{ng}$ BHA/ml plasma \\
$t 1 / 2$ & $58 \pm 33$ & $\mathrm{~min}$ \\
$A U C_{0}-00$ & $191 \pm 51$ & $\mathrm{ng} / \mathrm{h} / \mathrm{ml}$ \\
$V \mathrm{~d}$ & $2.9 \pm 2.5$ & $1 / \mathrm{kg}$ \\
$C L$ & $2.9 \pm 1.0$ & $1 / \mathrm{h} / \mathrm{kg}$
\end{tabular}

Blood was sampled and plasma BHA concentrations were determined as described in Materials and Methods. AUCs were calculated by the trapezoidal method. Kinetic parameters were calculated according to the equations: $C L=D / A U C$ and $V \mathrm{~d}=\left[C L^{*} t 1 / 2\right] / 0.693$. Valucs represent the mean $\pm \mathrm{SD}$. 


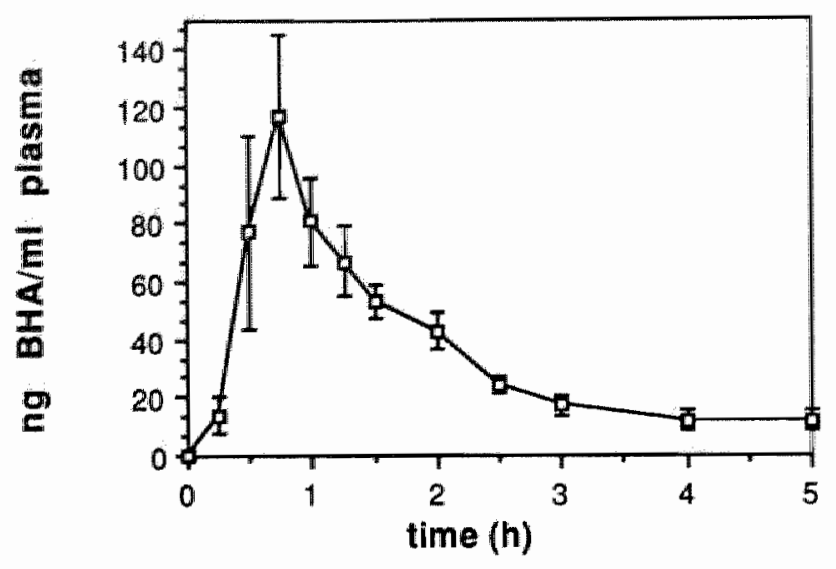

Figure 5-3: Mean plasma concentration-timte profile of BHA after oral administration of $0.5 \mathrm{mg} B H \mathrm{Al} / \mathrm{kg}$ body weight in $C O$ to nine male volunteers. Blood was sampled between $O$ and 5 h after dosing. Plasma BHA concentrations were determined as described in Materials and Methods. The limit of detection was $5 \mathrm{ng}$ $B H A / m l$ plasma. Walues are the mean $\pm S E$.

\section{Discussion}

BHA, together with other antioxidants, has a considerable range of modulating effects on chemically induced carcinogenesis and mutagenesis, exhibiting both anti- and procarcinogenic/mutagenic properties (Anonymous, 1984; Ito et al., 1985; Kahl, 1984; Kahl, 1986; Wattenberg, 1980; Wattenberg, 1985). Furthermore, oral administration of BHA to rodents reproducibly induces forestomach lesions, hyperplasia, papillomas and carcinomas ( Ito et al., 1985; Nera et al., 1984; Ito et al., 1983; Rodrigues et al., 1986; Iverson et al., 1985a; Altmann et al., 1985; Abraham et al., 1986; Ito et al., 1986; Masui et a1., 1986). The International Agency for Research on Cancer has stated that these studies of BHA provide "sufficient evidence for carcinogenicity" (Masui et al., 1986). Proliferative effects induced by BHA have also been found in pigs (Würtzen \& Olsen, 1986) and primates (Iverson et al., 1985 b). Little is known about the mechanism of carcinogenicity of BHA; however, structure-activity studies indicate that 3-BHA, the major isomer (CAS no. 88-32-4) is much more potent than 2-BHA, the minor isomer (CAS no. 121-00-6) (Hirose et al., 1986; Ito et al., 1984).

Risk assessment of human BHA consumption based on rodent carcinogenicity studies is difficult since primates do not have a forestomach. Recently, studies have shown that partial hepatectomy of rats administered BHA orally effectively reduced the latent period for the development of forestomach tumors (Abraham et al., 1986). Thus the hepatic metabolism of BHA may play a role in its carcinogenic behavior. Interspecies comparison of the biological fate of BHA can provide a useful tool to assess possible harmful effects of dietary BHA on human health. Therefore comparative experiments on the kinetics and metabolism of BHA in man and rat have been conducted. An oral dose of $200 \mathrm{mg} \mathrm{BHA} / \mathrm{kg}$ body weight is just below the no-effect level (NEL) in laboratory animals, used for the assessment of the ADI for BHA (JECFA, 1974), but is higher than the NEL recently observed in tumorigenicityrelated studies (Ito et al., 1986; Clayson et al., 1986).

Results indicate that plasma BHA profiles of rats, administered $200 \mathrm{mg} \mathrm{BHA} / \mathrm{kg}$ body weight are generally not influenced by the vehicle used. Reduced plasma BHA 
concentrations at this dose level were seen, however, when BHA was given as a suspension of $15 \%$ PEG. Tween -60 , a similar solvent, also gave reduced plasma BHA concentrations when used as a vehicle (Kangsadalampai et al., 1986). Furthermore, our results on plasmil BHA kinetics are in agreement with those of Bailey et al. (1981) but contrast with those of Guarna et al. (1983), who used larger concentrations (x10) of BHA and found plasma BHA peak concentrations about 100 times as high. This may reflect a non-linearity between the applied BHA dose and resulting plasma concentrations and indicates that the absorption of BHA is not maximal at a dose of $200 \mathrm{mg} / \mathrm{kg}$ body weight. Plasma BHA concentrations in rats, administered similar doses of $\mathrm{BHA}$, were higher when radio-labeled $\mathrm{BHA}$ was used (Kangsadalampai et al., 1986; Hirose et al., 1987; Ansari \& Hendrix, 1985), however, this method fails to distinguish between unchanged BHA and its metabolites (Minegishi et al., 1981).

The results obtained after administration (iv) of $\mathrm{BHA}$ to rats indicate a large volume of distribution $(V \mathrm{~d})$ and rapid plasma clearance $(C L)$ almost beyond physiological possibilities. Fast disappearance of BHA from rat plasma may be explained by: [1] metabolism in blood or storage in the blood cells; [2] metabolism elsewhere; [3] excretion into the urine or bile; or [4] adipose tissue storage. In experiments using rat blood spiked with $\mathrm{BHA}$ (up to $1 \mu \mathrm{g} / \mathrm{ml}$ ), plasma $\mathrm{BHA}$ concentrations remained constant at about 0.3 $\mu \mathrm{g} / \mathrm{ml} \mathrm{a} 37{ }^{\circ} \mathrm{C}$ in vitro for at least $6 \mathrm{~h}$, indicating partial uptake of $\mathrm{BHA}$ by the blood cells but no metabolism in the blood (data not shown). The observed $C L$ is slightly higher than mean cardiac output and much greater than the total blood flow through the kidneys and liver. Thus excretion into the urine or bile cannot be considered as the major clearance pathways. Only minor amounts of BHA were recovered from adipose tissue $24 \mathrm{~h}$ after administration, indicating no retention of BHA in this tissue, which is in agreement with other reports (Ansari \& Hendrix, 1985; Conacher et al., 1986). Using DMSO as the vehicle resulted in significantly higher levels of BHA in adipose tissue compared with those doses dissolved in SD, CO and 15\% PEG, which may reflect the somewhat higher absorption of BHA with the DMSO vehicle. It is therefore concluded that $C L$ must result mainly from metabolic activity.

To our knowledge this is the first study to report the in vivo metabolism of BHA to (conjugated) TBHQ in rats. In 1986 Conning and Phillips reported that the sulphate conjugate of BHA was formed in small amounts in the rat, rabbit and dog. Earlier studies had reported that in rats BHA was excreted in the urine mainly as the glucuronic acid and sulphate conjugates (Anonymous, 1984; Gage, 1966; Hathway, 1966). As noted, however, by El-Rashidy and Niazi (1983) it is not possible with the techniques used in those studies to distinguish between BHA and its $\mathrm{O}$-demethylated form. TBHQ. Recent studies using radio-labeled $\mathrm{BHA}$ have shown that $\mathrm{BHA}$ is readily $\mathrm{O}$-demethylated in rats in vitro and in vivo; the $\mathrm{O}$-demethylated product may be associated with formation of reactive oxygen species (Rahimtula, 1983; Cummings et al., 1985; DeStafney et al,, 1986; Kahl \& Hildebrandt, 1986; Hirose et al., 1987). Excretion of unchanged BHA suggests incomplete absorption and/or entero-hepatic circulation of BHA. In rats the mean urinary and fecal recovery of BHA was $95 \pm 10 \%$ of the orally administered dose and is in agreement with data from other studies using radio-labeled BHA (Kangsadalampai et al, 1986; Hirose et al., 1987; Ansari \& Hendrix, 1985).

The mean plasma profile of BHA in man dosed orally with $0.5 \mathrm{mg} \mathrm{BHA} / \mathrm{kg}$ body weight dissolved in $\mathrm{CO}$ is in close agreement with previous studies. Castelli et all. (1984) administered orally a comparable dose of BHA (30 mg/person) and found plasma BHA levels almost identical to profiles observed in three volunteers in our experiments. Six of our 
vollunteers, however, showed a plasma BHA peak concentration between 30 and 60 min with maximal plasma concentrations up to $255 \mathrm{ng}$ BHA/ml plasma. Studies by El-Rashidy and Niazi (1979) involving oral administration of $100 \mathrm{mg}$ BHA/person, about three times greater than our dose, indicated that within two hours after ingestion, plasma BHA peak concentrations were two to three times higher, up to $600 \mathrm{ng} / \mathrm{ml}$, than those of six of our volunteers.

Our results indicate that following oral administration of $200 \mathrm{mg} \mathrm{BHA} / \mathrm{kg}$ body weight to rats and $0.5 \mathrm{mg} / \mathrm{kg}$ body weight to man, plasma BHA concentrations in rat and man did not differ greatly. This may result in comparable BHA concentrations at the target tissues, despite the difference in oral BHA dose $(x 400)$. It should be borne in mind that in those species that do not possess a forestomach (e.g. pigs and monkeys) the oesophagus is a primary target for BHA (Wirtzen \& Olsen, 1986; Iverson et al., 1985 b) and that tissue levels of radio-labelled BHA, administered orally, in rat plasma, oesophagus and forestomach were in the same order of magnitude (Hirose et al., 1987). Judging from our results, combined with others (Bailey et al., 1981; Guarna et al., 1983; Castelli et al., 1984; El-Rashidy \& Niazi, 1979), the 'safety factor' inbuilt in calculations of the human ADI may be insufficient to protect man from the harmful effects of BHA.

Following oral administration of BHA, El-Rashidy and Niazi (1983) recovered more than $100 \%$ of the dose as conjugates of BHA and TBHQ in human urine over a period of $24 \mathrm{~h}$. We confirm the in vivo transformation of BHA to TBHQ by man, but found a recovery of only $49 \%$ of the administered dose. This discrepancy may be a result of the higher dose (1.7 $\mathrm{mg}$ BHA/kg body weight) used by El-Rashidy and Niazi (1983). As no significant BHA storage in adipose tissue was found, in agreement with results of Conacher et al (1986), and man excretes $80 \%-90 \%$ of an administered dose of radio-labelled BHA in urine (Daniel et al., 1967), it is suggested that unknown pathways of BHA metabolism must exist. Possible metabolites include tert-butyl-quinone, 3-tert-butyl-4,5-dihydroxyanisole, 3,3'-di-tertbutyl-2,2'-dihydroxy-5,5'-dimethoxydiphenyl, and sulfur-containing metabolites (Guama et al., 1983; Cummings et al., 1985; DeStafney et al., 1986; Armstrong \& Wattenberg, 1985). Results from this study and data from the literature indicated that oral administration of low doses of BHA in man easily produces plasma BHA levels comparable with those found in rats administered high doses of BHA. Urinary and fecal recovery of a high oral dose of BHA in rats is almost complete, but recovery of a low dose of BHA after oral ingestion by man is only half of the dose administered. In either species BHA is O-demethylated to TBHQ (about $9 \%$ of the dose). In man and rat only the fraction of BHA excreted in the urine as conjugates of BHA and TBHQ was comparable, which indicates that the biological fate of BHA in man and rat is very different. If in vivo metabolism and kinetics of BHA is associated with its carcinogenic potential after oral BHA intake, risk assessment of BHA consumption by man cannot be extrapolated from animal data.

\section{Acknowledgements}

The authors wish to thank Mr E. van Dam and Mr F. Weekers for excellent technical assistance, all volunteers for participating in the experiments and Mrs M. Peters for typing the report. 


\section{References}

- Abraham R., Benitz K.F., Patil G. and Lyon R. (1986). Rapid induction of forestomach tumors in partially hepatectomized Wistar rats given butylated hydroxyanisole. Expl. Molec. Pathol. 44: 14-20.

- Allen J.R. and Engblom J.F. (1972). Ultrastructural and biochemical changes in the liver of monkeys given butylated hydroxytoluene and butylated hydroxyanisole. Food Cosmet. Toxicol. 10: 769-779.

- Alumann H.J., Wester P.W., Matthiasehk G., Grunow W. and Van der Heyden C.A. (1985). A 13-weck feeding study of butylated hydroxyanisole: the subsequent regression of the induced lesions in male Fischer 344 rat forestomach epithelium. Food Chem. Toxicol. 23: 723-731.

- Ansari G.A.S. and Hendrix P.Y. (1985). Tissue distribution and pharmacokinetics of 3-1[methy $114 \mathrm{C}$ butyl-4-hydroxyanisole in rats. Drug Metab. Disp. 13: 535-541.

- Anonymous. (1984). Finall Report of the safety assessment for BHA. J. Am. Coll. Toxicol 3: 83-146.

- Archer A.W. (1981). The determination of phenolic antioxidants in edible oils and fats by high performance liquid chromatography. Analytica Chim. Acta 128: 235-237.

- Armstrong K.E. and Wattenberg L.W. (1985). Metabolism of 3-tert-butyl-4-hydroxyanisole to 3-tertbutyl-4,5-dihydroxyanisole by rat liver microsomes. Cancer Res. 45: 1507-1510.

- Bailey E., Della Corte L., Farmer P.B. and Gray A.l. (1981). Determination of the antioxidant 3-tertbutyl-4-hydroxyanisole in rat plasma using high-resolution gas chromatography-mass spectrometry. I. Chromatogr. 225: 83-89.

- Castelli M.G., Benfenati E., Pastorelli R., Salmona M. and Fanelli R.(1984) Kinetics of 3-tert-butyl4-hydroxyanisole (BHA) in man. Food Chem. Toxicol. 22: 901-904.

- Clayson D.B., Iverson F., Nera E., Lok E., Rogers C., Rodrigues C., Page D., and Karpinski K. (1986). Histopathological and autoradiographical studies on the forestomach of F344 rats treated with butylated hydroxyanisole and related chemicalls. Food Chem. Toxicol. 24: 1171-1182.

- Conacher H.B.S., Iverson F., Lau P.Y. and Page B.D. (1986), Levels of BHA and BHT in human and animal adipose tissue: interspecies extrapolation. Food Chem. Toxicol. 24: 1159-1162.

- Conning D.M. and Phillips J.C. (1986). Comparative metabolism of BHA, BHT and other phenolic antioxidants and its Loxicological relevance. Food Chem. Toxicol. 24: 1145-1148.

- Curnmings S.W., Anstari G.A.S., Guengerich F.P., Crough L.S. and Prough R.A. (1985). Metabolism of 3-tert-butyl-4-hydroxyanisole by microsomal fractions and isolated rat hepatocytes. Cancer Res. 45: 5617-5624.

- Daniel J.W., Gage J.C., Jones D.I. and Stevens M.A. (1967). Excretion of butylated hydroxytoluene (BHT) and butylated hydroxyanisole (BHA) by man. Food Cosmel. Toxicol. 5: 475-479.

- DeStafney C.M., Prabhu U.D.G., Sparnino V.L., and Wattenberg L.W.(1986). Studies related to the mechanism of 3-BHA-induced neoplasia of the rat forestomach. Food Chem. Toxicol. 24: 1149-1157.

- El-Rashidy R. and Niazi S. (1979). GLC determination of bulylated hydroxyanisole in human plasma and urine. J. Pharm. Sci. 68: 103-104.

- El-Rashidy R. and Niazi S. (1983). A new metabolite of butylated hydroxyanisole in man. Biopharm. Drug Dispos. 4: 389-396,

- Gage J.C. (1966). Der Metabolismus phenolischer Antioxidantien. Fette, Seifen, Anstrichum. 68: 951.

- Garattini S. (1986). Toxic effects of chemicals: difficulties in extra-polating data from animals to man. C.R.C. Crit. Rew. Toxicol. 16,1-20.

- Guarna A., Della Corte L., Giovannini M.G., De Sarlo F. and Sgaragli G. (1983). 2,2'-dihydroxy-3,3' * di-i-butyl-5, $5^{\prime}$-dimethoxydiphenyl $\mathbb{l}_{n}$ a new metabolite of 2-i-butyl-4-methoxyphenol in the rat. Drug Metab. Dispos. 11: 581-584.

- Hathway D.E. (1966). Metabolic fate of antioxidants in relation to their safety evaluation and antioxidant function. Adv, Food Res. 15: 1-50.

- Hirose M., Inoue T., Asamoto M., Tagawa Y. and Ito N. (1986) Comparison of the effects of 13 phenolic compounds in induction of proliferative lesions of the forestomach and increase in the labelling indices of the glandular stomach and urinary bladder epithelium of syrian golden hamsters. Carcinogenesis 7: 1285-1289.

- Hirose $M_{\text {.n }}$ Hagiwara A., Inoue K., Sakata T., Ito N., Kaneko H., Yoshitake A., and Miyamoto J. (1987). Metabolism of 2- and 3-tert-butyl-4-hydroxy-anisole (2-and 3-BHA) in the rat (1): excretion of BHA in urine, faeces and expired air and distribution of BHA in the main organs. Toxicology 43: 139. 147.

- Ito N., Fukushima S., Hagiwara A., Shibata M. and Ogiso T.(1983). Carcinogenicity of butylated 
hydroxyanisole in F344 rats. J. Natl. Cancer Inst. 70: 343-349.

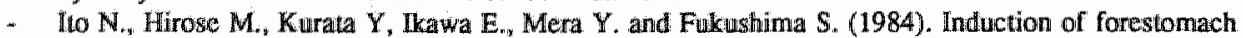
hyperplasia by crude butylated hydroxyanisole, a mixture of 3-tert and 2-tert isomers, in Syrian golden hamsters is due to 3-tert-butylated hydroxyanisole. Gann 75: 471-474.

- Ito $\mathrm{N}_{\text {, }}$, Fukushima $\mathrm{S}$. and Tsuda H. (1985). Carcinogenicity and modification of the carinogenic response by BHA, BHT and other antioxidants. C.R.C. Crit. Rev. Toxicol. 15: 109-150.

- Ito N., Fukushima S., Tamano $S_{\text {. }}$ Hirose M., and Hagiwara A. (1986). Dose response in butylated hydroxyanisole induction of forestomach carcinogenesis in F344 rats. J. Natl. Cancer Inst. 77: 12611265.

- Iverson F., Lok E., Nera E., Karpinski K. and Clayson D.B. (1985a). A 13-week feeding study of butylated hydroxyanisole: the subsequent regression of the induced lesions in male Fischer 344 rat forestomach epithelium. Toxicology 35: 1-11.

- Iverson F, Truelove J., Nera E., Wong J., Lok E. and Clayson D.B. (1985b) An 85-day study of butylated hydroxyanisole in the cynomolgus monkey. Cancer Lett. 26:43-50.

- Joint FAO/WHO Expert Committee on Food Additives (1974). Toxicological evaluation of some food additives including anticaking agents, antimicrobials, antioxidants, emulsifiers and thickening agents. WHO Fd. Add, Ser. No.S: 148.

- Joint FAO/WHO Expert Committee on Food Additives (1986). Toxicological evaluation of certain food additives and contaminants. WHO Fd. Add. Ser. No.21: 3-24.

- Kahl, R. (1984). Synthetic antioxidants: biochemical actions and interference with radiation, toxic compounds, chemical mutagens and chemical carcinogens. Toxicology 33: 185-228.

- Kahi R. (1986). The dual role of antioxidants in the modification of chemical carcinogenesis. J. Environ. Sci. Health 4(1): 47-92.

- Kahl R. and Hitdebrandt A.G. (1986). Methodology for studying antioxidant activity and mechanisms of action of antioxidants. Food Chem.Toxicol. 24: 1007-1014.

- Kangsadalampai K., Sharma R.P., Taylor M.J. and Salunkhe D.K. (1986). Effect of protein deficiency and Tween 60 on the pharmacokinetics of butylated hydroxyanisole and metabolites in male SpragueDawley rats. Drug Nutr. Interact. 4: 289-297.

- Masui T., Hirose M., Imaida K., Fukushima S., Tamano S. and Ito N. (1986). Sequential changes of the forestomach of F344 rats, syrian golden hamsters, and B6C3F, mice treated with butylated hydroxyanisole. Gann 77: 1083-1090.

- Minegishi K., Watanabe M. and Yamaha T. (1981). Distribution of butylated hydroxyanisole and its conjugates in the tissues of rats. Chem. Pharm. Bull. 29: 1377-1381.

- Nera E.A. Lok E., Iverson F., Ormsky E., Karpinski K.F., and Clayson D.B. (1984). Short-4erm pathological and proliferative effects of butylated hydroxyanisole and other phenolic antioxidants in the forestomach of Fischer 344 rats. Toxicology $32:$ 197-213.

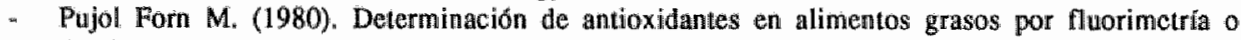
densitometría tras su separación por chromatograffa en capa fina. Grasas y aceites 31: 187-195.

- Rahimtulla A, (1983). In vitro metabolism of 3-tert-butyl-4-hydroxyanisole and its irreversible binding to proteins. Chem. Biol. Interact. 45: 125-135.

- Rodrigues C., Lok E., Nera E, Iverson F., Page D., Karpinski K. and Clayson D.B. (1986). Short-term effects of various phenols and acids on the Fischer 344 male rat forestomach epithelium. Toxicology 38: $103-117$.

- Sims R.J. and Fioriti J.A. (1980) Antioxidants as stabilizers for fats, oils, and lipid-containing foods. In: CRC Handbook of food additives, Vol. II, edlited by T.E. Furia, 2nd Ed, pp. 13-56. Chemical Rubber Company, Boca Raton, FL.

- Tobe M., Furnya T., Kawasaki Y., Naito K., Sekita K., Matsumoto K., Ochiai T., Usui A., Kokubo T., Kanno J., and Hayashi Y. (1986). Six-month toxicity study of butylated hydroxyanisole in beagle dogs. Food Chem. Toxicol. 24: 1223-1.228.

- Verhagen H, Thijssen H.H.W. and Kleinjans J.C.S. (1987). Sensitive high-performance liquid chromatographic method for the routine determination of butylated hydroxyanisole in plasma. J. Chromatogr. 413: 282-286.

Wattenberg L.W. (1980). Inhibitors of chemical carcinogens. J. Environ. Pathol. Toxicol. 3: 35-52.

Wattenberg L.W. (1985). Chemoprevention of cancer. Cancer Res. 45:1-8.

- Whittemore A., Grosser S.C., and Sillvers A. (1986). Pharmacokinetics in low dose extrapolation using animal cancer data. Fundam. Appl. Toxicol. 7: 183-190.

- Wurtzen G., and Olsen P. (1986). BHA study in pigs. Food Chem.Toxicol. 24: 1229-1233. 


\title{
Chapter 6
}

\section{Biliary excretion of butylated hydroxyanisole in the rat}

\author{
Hans Verhagen and Jos C.S. Kleinjans \\ Food and Chemical Toxicology, in press
}

It has previously been reported that following administration of a single oral dose of the food additive butylated hydroxyanisole BHA (200 mg/kg body weight), plasma BHA concentrations rose steadily in the first $30 \mathrm{~min}$, declined thereafter with a temporary minimal level observed at around $90 \mathrm{~min}$, and then increased again (Verhagen et al., 1989). Recently, while presenting two papers on part of this work (Verhagen et al., 1987; 1988), it was suggested that this biphasic kinetic plasma profile of $\mathrm{BHA}$ in the rat might be a result of entero-hepatic circulation of BHA. To our knowledge no data exist on the biliary excretion of BHA (Conning and Phillips, 1986).

To study this hypothesis, a catheter was inserted into the bile duct of three male Wistar rats under ether anaesthesia. While anesthesized, each rat was given by gavage a solution of 200 mg BHA/kg body weight dissolved in dimethylsulphoxide. A volume of $1 \mathrm{ml}$ solution $/ \mathrm{kg}$ body weight was administered. Conscious rats were kept in a restraining device. A single bile sample from each rat, covering a period of $6 \mathrm{~h}$, was collected by means of the catheter. Bile was analysed immediately for unconjugated (free) BHA or its demethylated metabolite tert-butylhydroquinone (TBHQ) using high-performance liquid chromatography as described previously (Verhagen et al., 1989). Similarly, conjugates of BHA and TBHQ were measured following overnight incubation of bile with B-glucuronidase/arylsulphatasecontaining limpet acetone powder (type I)(Sigma Chemical Co., St. Louis, MO, USA) at 37 ${ }^{\circ} \mathrm{C}$

Results from these experiments indicate that large amounts of conjugated BHA and small fractions of unconjugated TBHQ are excreted in the bile over a period of $6 \mathrm{~h}$ following oral administration of $\mathrm{BHA}$ (Table 6-I).

It is concluded that excretion of BHA in the rat occurs to a large extent in the bile. This indicates that the biphasic kinetic plasma profile of BHA in this species may indeed be a result of deconjugation of BHA-glucuronide and BHA-sulphate in the gut, followed by a renewed uptake of free BHA into the circulation, otherwise known as entero-hepatic circulation. It is not known whether this phenomenon also occurs in man, or contributes to the toxic effects of BHA in rats . 
TABLE 6I: BILIARY EXCRETION OF BHA AND ITS METABOLITES IN THE BILE OF RATS OVER A PERIOD OF $6 \mathrm{~h}$ FOLLOWING ORAL ADMINISTRATION OF BHAa.

\begin{tabular}{llllll}
\hline $\begin{array}{l}\text { body weight } \\
\text { rat }\end{array}$ & $\begin{array}{l}\text { free BHA } \\
(\%)\end{array}$ & $\begin{array}{l}\text { total BHA } \\
(\%)\end{array}$ & $\begin{array}{l}\text { free TBHQ } \\
(\%)\end{array}$ & $\begin{array}{l}\text { total TBHQ } \\
(\%)\end{array}$ \\
\hline 1 & 300 & 0 & 41 & 0.4 & 0.4 \\
2 & 400 & 0 & 66 & 0.6 & 0.6 \\
$3^{*}$ & 400 & 0 & 26 & 0.2 & 0.2 \\
\hline
\end{tabular}

a: Rats were given by gavage a solution of $200 \mathrm{mg} \mathrm{BHA} / \mathrm{kg}$ body weight dissolved in dimethylsulphoxide. A volume of $1 \mathrm{ml}$ solution $/ \mathrm{kg}$ body weight was administered.

b: Values are expressed as a percentage of the administered dose.

c: Bile was collected only for 2 h owing to an obstruction in the catheter.

\section{Acknowledgements}

We wish to thank Mr. L. Baars, Mr. F. Weekers and Mr. P. Kelderman for their excellent technical assistance.

\section{References}

- H. Verhagen, H.H.W. Thijssen, F. ten Hoor and J.C.S. Kleinjans (1987). Comparison of the disposition of single oral doses of BHA and BHT in man and rat. Pharmac. Weekbl. Sci. Ed. 10: 301.

- H. Verhagen, H.H.W. Thijssen and J.C.S. Kleinjans (1988). Fate of the food additive butylated hydroxyanisole in man and rat. Human Toxicol. 7: 70-71.

- H. Verhagen, H.H.W. Thijssen, F. ten Hoor and J.C.S. Kleinjans (1989). Disposition of single orall doses of butylated hydroxyanisole in man and rat. Food Chem. Toxicol. 27: 151-158.

- D.M. Conning and J.C. Phillips (1986). Comparative metabolism of BHA, BHT and other phenolic antioxidants and its toxicological relevance. Food Chem. Toxicol. 24: 1145-1148. 


\title{
Chapter 7
}

\author{
Disposition of single oral doses of \\ butylated hydroxytoluene in man and rat
}

\author{
Hans Verhagen, Rico H.G. Beckers, Petra A.W.V. Comuth, Lou M. Maas, \\ Foppe ten Hoor, Peter Th. Henderson and Jos C.S. Kleinjans \\ Food and Chemical Toxicology, in press
}

\begin{abstract}
Kinetics and metabolism of the phenolic food antioxidant butylated hydroxytoluene (BHT) are compared between man and rat. Applied oral doses were 200,63 and $20 \mathrm{mg} B H T / \mathrm{kg}$ to rats and $0.5 \mathrm{mg} / \mathrm{kg}$ to $\mathrm{man}$. In rats, kinetic parameters (area under the plasma concentration-time curve, plasma BHT peak levels) showed a dose-dependent increase. In comparison with another synthetic food antioxidant, butylated hydroxyanisole (BHA), plasma BHT levels after oral administration are about four times higher, which may be a reflection of a smaller volume of distribution for BHT, since there is no difference in plasma elimination half life or plasma clearance between BHT and BHA. In man, mean plasma concentration-time profile after oral BHT intake is well below BHT profiles in rat and closely follows plasma BHA kinetics in man.

In rat, simultaneous administration of BHT $(200 \mathrm{mg} / \mathrm{kg})$ and BHA (200 $\mathrm{mg} / \mathrm{kg}$ ) significantly decreases the absorption of BHT from the gastrointestinal tract in the first hours following antioxidant intake; plasma kinetics of BHA are not influenced. In man, no altered plasma BHT or BHA profiles were seen after simultaneous ingestion of BHT $(0.25 \mathrm{mg} / \mathrm{kg})$ and BHA $(0.25 \mathrm{mg} / \mathrm{kg})$.

Rats excrete about $10 \%$ of an oral dose of $200 \mathrm{mg}$ BHT/kg as unchanged BHT in feces, while in man no BHT could be detected in feces. Urinary excretion of (un)conjugated 3,5-di-tert-butyl-4-hydroxybenzoic acid (BHT$\mathrm{COOH}$ ) accounts for only a small percentage of the administered dose in either species.

Based on plasma concentrations reached after oral administration of a single dose of BHT, it is concluded that there is no reason to expect toxicity of BHT in man after ingestion of doses corresponding to the Acceptable Daily Intake.
\end{abstract}




\section{Introduction}

The food additive butylated hydroxytoluene [3,5-di-tert-butyl-4-hydroxytoluene] (BHT; CAS no. 128-37-0) is a phenolic antioxidant which is widely used in oils, fats, shortenings and non-food products (Sims and Fioriti, 1980; Anonymous, 1986). BHT has been the subject of many toxicological studies, including carcinogenicity studies (for review see: Hirose et al. 1981; Babich 1982; Malkinson 1983; Wattenberg 1985; Ito et al. 1985; Ito and Hirose, 1987; Kahl 1986; Anonymous 1986). Its toxilcity in rodents is mainly associated with the liver (Nakagawa et al. 1984) and lungs (Marino and Mitchell 1972). At high doses BHT causes hemorrhagic death in laboratory animals due to interference with the blood coagulation system (Takahashi and Hiraga 1981). The major scientific interest for BHT is not associated with its toxicity however, but with its modulating effects on chemical-induced mutagenesis and carcinogenesis (Wattenberg, 1985; Ito et al., 1985; Ito and Hirose, 1987; Anonymous, 1986; Kahl, 1986; Witschi, 1986; Kitchin and Brown, 1987). BHT is a potent promotior as well as inhibitor of tumor development in laboratory animals. Its behavior may depend on mode and time of administration, target tissue, species and type of carcinogen administered. Further, there is "limited evidence" (Anonymous, 1986) for carcinogenic properties of BHT per se in livers of rats (Olsen et al., 1986) and mice (Lindenschmidt et al., 1986). Also, the incidence of mild hyperplasia in hamster forestomach, the target tissue for the carcinogenic action of the BHT congener butylated hydroxyanisole (BHA), was slightly higher after oral BHT intake (Hirose et al. 1986). BHT is not mutagenic in the Salmonella/microsome assay (Hageman et al. 1988), but it induces chromosomal abnormalities in vitro (Patterson et al. 1987).

In the light of these findings, the Joint FAO/WHO Expert Committee on Food Additives (JECFA) has recently lowered the temporary acceptable daily intake (ADD) for BHT - alone or in combination with BHA and/or tert-butylhydroquinone from $0-0.5 \mathrm{mg} / \mathrm{kg}$ to $0-0.125$ $\mathrm{mg} / \mathrm{kg}$ body weight (JECFA, 1986).

In contrast to the metabolism of BHT which has been studied extensively (Dacre, 1961; Golder et al., 1962; Daniel et al., 1967, 1968; Holder et al., 1970a , 1970b; Wiebe et al., 1978; Matsuo et al,, 1984; Conning and Phillips, 1986), little is known about the plasma kinetics of BHT in man or animal (Wiebe et al., 1978; El-Rashidy and Niazi, 1980; Rao and Wong, 1983; Matsuo et al., 1984; Terao et al., 1985). Limited availability of data on the biological fate of BHT is merely a result of the previous lack of an adequate method for measuring plasma BHT-concentrations. We recently reported a high-performance liquid chromatography (HPLC) method for determination of plasma BHT-levels, which is sufficiently sensitive to measure plasma BHT concentrations in man (Verhagen et al. $1987 \mathrm{a})$.

The mechanisms by which phenolic antioxidants exert their carcinogenic action in laboratory animals, are not well understood. Interspecies comparison of kinetics and biotransformation in man vs animal may contribute to a better assessment of risk associated with human exposition to xenobiotics (Garattini, 1986; Whittemore et al., 1986). In a previous paper on $\mathrm{BHA}$, we showed that a single oral administration of $\mathrm{BHA}$ of the $\mathrm{ADI}(0.5 \mathrm{mg} / \mathrm{kg})$ to male volunteers and a dose of $200 \mathrm{mg} / \mathrm{kg}$ to rats resulted in plasma BHA-levels in the same order of magnitude despite the 400 times difference in dose (Verhagen et al., 1989). We now report the results of a similar study on BHT. Since BHT and BHA may be ingested simultaneously by man, the effects of BHA and BHT on the kinetics of BHT and BHA, respectively, were investigated in man and rat. 


\section{Materials and methods}

\section{Chemicals}

Food-grade BHT (purity $>99 \%$ ) as well as BHA (purity $>99 \%$ ) were a generous gift of J. Dekker Company (Wormerveer, The Netherlands). 35-di-tert-butyl-4-hydroxyanisole (DBHA; purity $>97 \%$ ) and 6-tert-butyl2,4-dimethylphenol (BDMP, purity >99\%) were obtained from Aldrich (Brussels, Belgium) 3,5 -di-tertbutyl-4-hydroxybenzoic acid (BHT-COOH; purity $>99 \%$ ) was obtained from Janssen Chimica (Beerse, Belgium). B-glucuronidase/arylsulfatase (E.C.3.2.1.31/E.C.3.1.6.1) was purchased from Boehringer (Mannheim, FRG). Diethylether was obtained from BDH (Poole, UK) and HPLC-grade acetonitrite from Fisons (Loughborough, England). Water was purified using a Milli-Q water purification system (Millipore, Molsheim, France). Analytical-grade chemicals were used in all other instances.

\section{Animal experiments}

Male Wistar rats $(326 \pm 36 \mathrm{~g} ;$ mean $\pm \mathrm{SD}$; Winkelmann, Borchem, FRG) were catheterized in the right femoral artery under ether anaesthesia. After fasting overnight, rats received an oral dose of $200 \mathrm{mg} / \mathrm{kg}$ $(\mathrm{n}=10), 63 \mathrm{mg} / \mathrm{kg}(\mathrm{n}=5)$ or $20 \mathrm{mg} / \mathrm{kg}(\mathrm{n}=2)$ of BHT dissolved in corn oil. In all instances $1.0 \mathrm{mll}$ solution per $\mathrm{kg}$ body weight was administered. In order to determine plasma BHT kinetics, blood samples $(400-450 \mu \mathrm{l})$ were collected in heparinized vessels at $0,15,30,45,60,90,120,180,240,360$ and 480 min after BHT administration. Samples were centrifuged for $5 \mathrm{~min}$ at $2000 \mathrm{~g}$ in order to separate plasma from blood cells. Plasma was stored at $-20^{\circ} \mathrm{C}$ until analysis. Washed blood cells $(0.5 \mathrm{ml})$ diluted 1 to 1 with $0.9 \% \mathrm{NaCl}$ were readministered after blood-sampling at 90 and $180 \mathrm{~min}$ in order to protect the animals from anaemia. Food access was not allowed until eight hours after oral antioxidant administration.

For determination of plasma BHT kinetics after intravenous administration, the right femoral artery and wein of three rats $(375,330$ and $270 \mathrm{~g}$ respectively) were cannulated. Next day, after fasting overnight, $1.0 \mathrm{ml} / \mathrm{kg}$ of a solution of $5 \mathrm{mg} \mathrm{BHT} / \mathrm{ml}$ in dimethylsulphoxide (DMSO) was injected intravenously. Blood samples $(400-450 \mu \mathrm{l})$ were taken after $0,5,10,15,30,45,60,120,180,300$ and $420 \mathrm{~min}$ and 24 hours and treated as described above. Washed and diluted blood cells were readministered after 60,120 and $420 \mathrm{~min}$.

For simultaneous determination of plasma BHT- \& BHA-kinetics, rats $(n=8)$ were cannulated as described above. On $t=0$ the animals received by gavage a solution ( $2 \mathrm{ml}$ per $\mathrm{kg}$ body weight) of $100 \mathrm{mg}$ BHT and 100 $\mathrm{mg} \mathrm{BHA} / \mathrm{ml}$ in corn oil. Blood samples $(400-450 \mu \mathrm{l})$ were taken after $0,5,10,15,30,45,60,120,180$, 300 and $420 \mathrm{~min}$ and treated as described above. Washed and diluted blood cells were readministered after 60 , 120 and 420 min. Food access was not allowed until eight hours after oral antioxidant administration.

For biotransformation experiments, five rats $(275 \pm 7 \mathrm{~g}$; mean $\pm S D)$ were individually housed in metabolic cages. After an overnight fast, $200 \mathrm{mg}$ BHT/kg was administered by gavage as a solution of $200 \mathrm{mg} / \mathrm{ml} \mathrm{in}$ corn oil. Subsequently urine and feces were collected daily for 4 consecutive days and stored at $-20^{\circ} \mathrm{C}$ until analyzed.

\section{Human experiments}

Seven bealthy mon-smoking male volunteers $(73 \pm 7 \mathrm{~kg}$ ) were recruited among laboratory personnel. After fasting overnight, they ingested a gelatin capsule containing $0.5 \mathrm{mg}$ BHT/ $/ \mathrm{kg}$ body weight as a solution of $10 \%$ BHT in corn oil. Blood samples $(5 \mathrm{ml})$ were taken from a catheter in an ann vein after $0,15,30,45$, $60,75,90,120,150,180$ and 240 min. The heparinized blood was centrifuged and stored as described above. Eating was permitted after 90 min. Volunteers collected their total production of urine and feces for two days following BHT ingestion. Samples of urine and homogenized feces were stored at $-20^{\circ} \mathrm{C}$ until analysis.

For simultancous investigation of plasma BHT- \& BHA-kinetics in man, five healthy female vollunteers (64 $\pm 12 \mathrm{~kg}$, including one smoker) were recruilied from the student population of the University of Limburg. After fasting owernight, they ingested $0.25 \mathrm{mg} / \mathrm{kg}$ BHA as a solution of $10 \%$ in con oil. One wcek later, this experiment was repeated using BHT $(0.25 \mathrm{mg} / \mathrm{kg})$ instead of BHA. After another week, BHA $(0.25$ $\mathrm{mg} / \mathrm{kg})$ and BHT $(0.25 \mathrm{mg} / \mathrm{kg})$ were ingested simultaneously. In all three experiments blood sampling was performed as described above.

\section{Analytical procedures}

Anallysis of plasma BHT concentrations was performed as described previously (Verthagen et al. 1987 Limit of detection was $0.1 \mu \mathrm{g} / \mathrm{m})$ for rat plasma $(200 \mu \mathrm{l}$ samples) and $20 \mathrm{ng} / \mathrm{ml}$ for human plasma $(1.0 \mathrm{ml}$ samples).

For simultaneous determination of BHT and BHA in plasma, our previously described methods for BHT 
(Verhagen et al. 1987 ) and BHA (Verhagen et al. $1987^{b}$ ) were slighty modified. Rat plasma $(0.2 \mu)$ was difuled to $1.0 \mathrm{ml}$ with water; human plasma $(1 \mathrm{ml})$ wass used undiluted. $100 \mu \mathrm{l}$ methanol was added containing $20 \mu \mathrm{g} / \mathrm{m}$ BDMP as an internal standard. Samples were extracted with 5 mll oil-enriched diethylether for $30 \mathrm{~min}$ and centrifuged for $5 \mathrm{~min}$ at $700 \mathrm{~g}$. The organic phase was separated in screw-capped pyrex gllass tubes (100x 16 mim: Bibby, Stone, England) and evaporated to dryness at $0^{\circ} \mathrm{C}$ under a gentle stream of $\mathrm{N}_{2}$. The residue was dissolved in $1 \mathrm{ml}$ concentrated HCl/methanol $(1 / 1, \mathrm{v} / \mathrm{v})$ and incubated in the closed tubes for 1 hour at $95^{\circ} \mathrm{C}$ in a shaking water bath in order to dealkylate BHT. After cooling on ice, 2.5 mil water was added and samples were again extracted with $5 \mathrm{ml}$ diethylether for $30 \mathrm{~min}$, centrifuged for $5 \mathrm{~min}$ at $700 \mathrm{~g}$ and the organic phase evaporated to dryness al $0{ }^{\circ} \mathrm{C}$ under a stream of $\mathrm{N}_{2}$. The residue was dissolved in $0.5 \mathrm{ml}$ of eluting solvent. For HPLC analysis, $100 \mu \mathrm{l}$ were injected anto a LiChrosorb RP-18 $10 \mathrm{~cm}$ cartridge column and appropriate guard column (Chrompack, Middelburg, The Netherlands). The eluent consisted of acetonitrile/water/acetic acid $(45 / 54 / 1$, v/v/v); flow was $1 \mathrm{ml} / \mathrm{min}$. The effluent was monitored with a Kratos \$pectroflow 980 programmable fluorescence detector set at $273 \mathrm{~nm}$ excitation wavelength and a cul-off filter at 320 nm. Retention tímes of BHA, dealkylated BHT and non-dealkylated BDMP were 3.6, 7.0 and 10.7 min respectively. The performance of this combined method for BHT and BHA was equivalent to the previously published separate determinations of BHT and BHA.

For the determination of conjugated BHT-COOH, $0.25 \mathrm{ml}$ rat urine, diluted with $0.5 \mathrm{ml}$ water, or $0.75 \mathrm{ml}$ human unine were added to $0.25 \mathrm{ml} 2 \mathrm{M}$ sodium-acetate buffer $\mathrm{pH} 4.8$ and $50 \mu \mathrm{l} \mathrm{B}$-glucuronidase/aryisulfatase and incubated overnight at $37^{\circ} \mathrm{C}$. Next day samples were extracted with $5 \mathrm{ml}$ diethylether for $15 \mathrm{~min}$ and subsequently centrifuged for $5 \mathrm{~min}$ at $700 \mathrm{~g}$. The organic phase was carefully separated, added to $2.5 \mathrm{ml} / 5 \%$ $\mathrm{Na}_{2} \mathrm{CO}_{3}$ solution and shaken for $15 \mathrm{~min}$ in order to transter BHT-COOH to the aqueous phase. After centrifugation ( 5 min at $700 \mathrm{~g}$ ), the organic phase was discarded. The watery ptvase was washed twice with $2.5 \mathrm{ml}$ diethylether and $2 \mathrm{ml} / \mathrm{N} \mathrm{HCl}$ was added; subsequently samples were mixed vigorously for $5 \mathrm{~s}$ to remove all $\mathrm{CO}_{2}$-gas and extracted with $5 \mathrm{ml}$ diethylether for $30 \mathrm{~min}$. After centrifugation for $5 \mathrm{~min}$ at $700 \mathrm{~g}$, the organic phase was carefully separated and evaporated to dryness at $0^{\circ} \mathrm{C}$ under a stream of $\mathrm{N}_{2}$. The residve was taken up in $1.0 \mathrm{ml}$ eluting solvent. For HPLC $20 \mu$ were injected onto a LiChrosorb 5-RP-18 column $(150 \times 4.6 \mathrm{~mm})$ and appropriate guard column (Chrompack, Middelburg, The Netherlands). The eluent (acetonitrile/water/acetic acid, 40/59/1, v/v/v) was recycled at a flow rate of $2 \mathrm{ml} / \mathrm{min}$. The effluent was monitored with a Kratos Spectroflow 783 programmable UV absorbance detector set at $260 \mathrm{~nm}$. The retention time of $\mathrm{BHT}-\mathrm{COOH}$ was $6.0 \mathrm{mim}$. No internal standand was used in this procedure.

For the determination of free (unconjugated) $\mathrm{BHT}-\mathrm{COOH}$ in urine, the procedure was essentially the same as described above, except for the addition of B-glucuronidlase/arylsulfatase and the incubation overnight. With rat urine, unlike human urine, unknown peaks were encountered in the chromatograms which interfered with the deternination of BHT-COOH. Therefore the limit of detection was $1 \mu \mathrm{g} / \mathrm{ml}$ (rat urine) or $0.02 \mu \mathrm{g} / \mathrm{ml}$ (human urine). Recovery of BHT-COOH was $>90 \%$.

Free BHT in feces was determined as follows. Feces (up to $10 \mathrm{~g}$ ) was mixed with $30 \mathrm{~g} \mathrm{Na} 2 \mathrm{SO}_{4}$ and finely homogenized using a mortar and a pestle. To each gram of feces $100 \mathrm{mg}$ corn oil containing $1.00 \mathrm{mg}$ DBHA/g was added to serve as an internal standard. After extraction ovemight in a Soxhlet apparatus with light petroleum (Fisons, Loughborough, England), extraction equivalents of $0.5 \mathrm{~g}$ (rat) or $2.5 \mathrm{~g}$ (man) feces were evaporated to dryness under $\mathrm{N}_{2}$ or by means of a rotary evapourator. The oily residue was extracted five times with $1 \mathrm{ml}$ methanol. Excessive lipid material. was removed by cooling on ice and centrifugation (10 min at $2000 \mathrm{gg}$ ). 0.5 oni of the methanol phase eventually concentrated to small volume was mixed with 0.5 $\mathrm{m}$ l concentrated $\mathrm{HCl}$ and incubated for 1 hour at $95{ }^{\circ} \mathrm{C}$. From this point the procedure was the samc as described for plasma BHT determinations (Verhagen et al., 1987b). Limit of detection was about $10 \mu \mathrm{g}$ BHT/g foces (man).

\section{Statistics}

Good linear relationships were found in all calibration graphs $(r>0.98)$. Measurements were performed in duplicate, except for plasma BHT and BHT\&BHA levels in rats, which were single determinations owing to the small amounts of plasma available. Student-t test for unpaired values was applied to assess statistical significance of differences, except for studies on simultaneous administration of BHT and BHA to women, in which case a paired $t$-test was applied; $p<0.05$ was considered significant. 


\section{Results}

Plasma BHT profiles after oral administration of $200(n=10), 63(n=5)$ or $20(n=2) \mathrm{mg}$ BHT/kg body weight to rats are shown in Figure 7-1. Maximal plasma BHT concentrations were observed in the two highest dosage groups after 2 to 4 hours on the average. Rats given $20 \mathrm{mg} \mathrm{BHT} / \mathrm{kg}$ showed plasma BHT levels around the limit of detection with no clear peak concentration-time profile. The area under the plasma concentration-time curve (AUC) (determined for $0-8$ hours after administration) was $7.7 \pm 2.7,2.0 \pm 1.4,0.3 \pm 0.4 \mu \mathrm{gg} . \mathrm{h} / \mathrm{ml}$ (mean \pm SD) for rats given 200,63 and $20 \mathrm{mg} / \mathrm{kg}$ respectively, thus indicating a dose dependent increase. Plasma BHT peak concentrations for rats given 200,63 and $20 \mathrm{mg} / \mathrm{kg}$ were $2.3 \pm 0.9,0.8 \pm 0.3,0.2 \pm 0.3 \mu \mathrm{g} / \mathrm{ml}$, respectively, and were reached $2.6 \pm 1.4$ hours (mean \pm SD) after oral administration of BHT.

Rats intravenously injected with $5 \mathrm{mg} \mathrm{BHT} / \mathrm{kg}$ in DMSO produced plasma profiles as shown in Figure 7-2. Immediately after administration rats became drowsy but recovered within 5-10 min. Marked hemolytic activity was observed in blood samples from 5 to 180 min by a reddish coloring of the plasma. The second blood sample was not taken until 5 min after administration to avoid the distribution phase. A log-linear fall in plasma BHT levels was observed until after one hour the detection limit was reached. Kinetic parameters. calculated from this period are summarized in table 7-I. As compared to data from a similar experiment using BHA instead of BHT (Verhagen et al., 1989), plasma elimination half life $(t 1 / 2)$ of BHT vs BHA was not significantly different. The volume of distribution $(V \mathrm{~d})$ for BHT was about two times smaller than for BHA and the apparent plasma concentration att time zero (Co) was four times higher for BHT. Plasma clearance $(C L)$ calculated by the model-independent equation $C L=D / A U C(D=$ dose) was equal for both antioxidants as was the $A U C$.

Figure $7-3^{\mathrm{a}}$ shows plasma concentration-time profiles of BHT in rats after oral administration of BHT (200 mg/kg; the same curve as in Figure 1) and of BHT $(200 \mathrm{mg} / \mathrm{kg})$ in combination with BHA $(200 \mathrm{mg} / \mathrm{kg})$, the latter curve showing concentrations of BHT between 0.5 and 3 hours, which were significantly lower, but no difference in plasma BHT levels from 4-8 hours. In the case of BHA however (Figure 7-3 b) there was no large difference in plasma concentration-time profiles whether BHA was applied alone (data from Verhagen et al., 1989) or in combination with BHT.

Figure 7-4 shows the average plasma concentration-time profile of BHT in seven male volunteers. Plasma BHT levels gradually increased from 0-75 min and decreased thereafter. However, large inter-individual variations were observed. Some volunteers demonstrated plasma BHT (peak) levels up to $250 \mathrm{ng} / \mathrm{ml}$ while in others no BHT was detectable at all. Mean $A U C$ and peak concentration were $76 \pm 65 \mu \mathrm{g} \cdot \mathrm{h} / \mathrm{l}$ and $0.09 \pm 0.10 \mu \mathrm{g} / \mathrm{ml}$ (mean \pm $\mathrm{SD}$ ) respectively. Owing to the large variations between individual plasma curves, other kinetic parameters could not reliably be calculated.

In women, there was no difference in plasma BHT or BHA concentration-time profiles, whether these antioxidants were administered alone or in combination (Figure 7-5). 


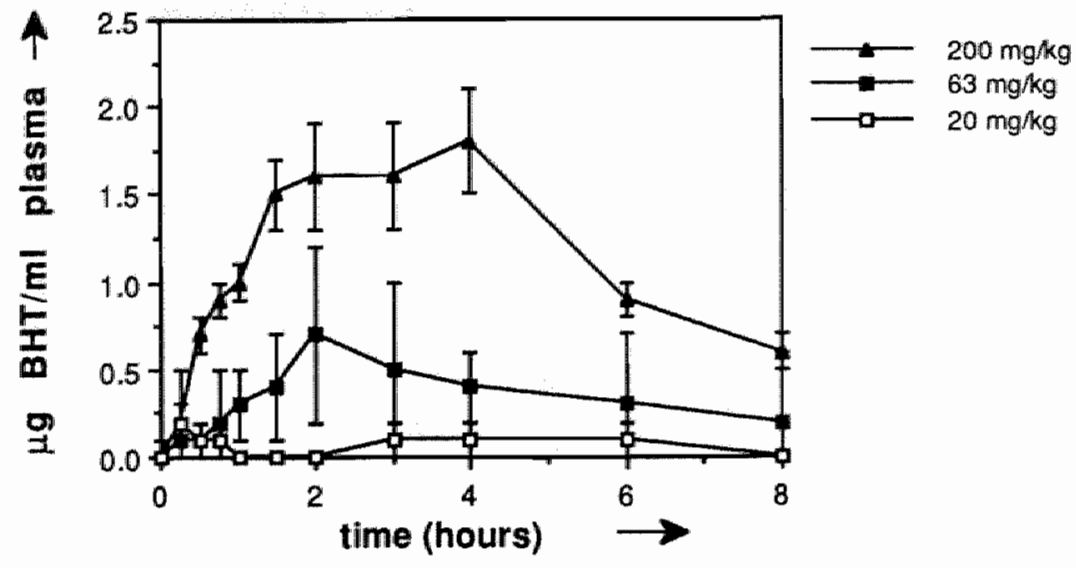

Figure 7-1: Mean plasma concentration-time profile in rats orally dosed with $200(n=10), 63(n=5)$ or 20 $(n=2) \mathrm{mg} \mathrm{BHT} / \mathrm{kg}$ body weight. Limit of detection $=0.1 \mu \mathrm{g} B H T / \mathrm{ml}$. Mean $\pm S E$.

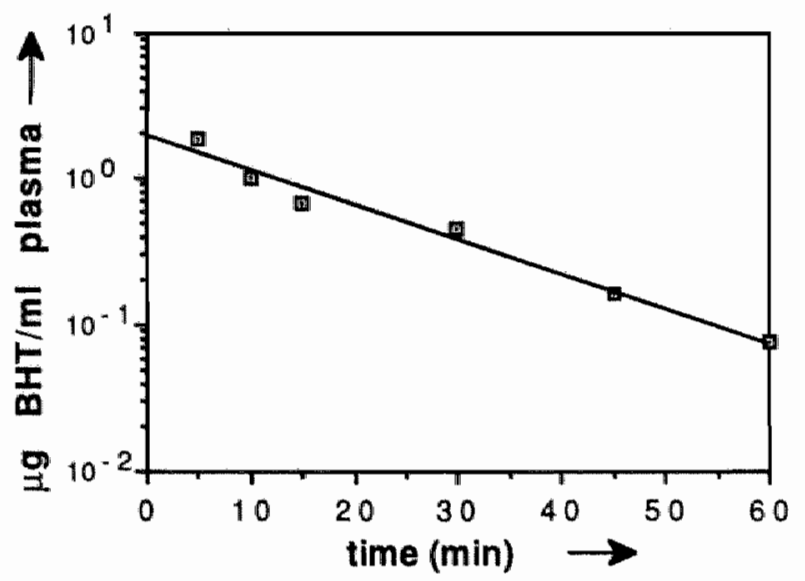

Figure 7-2: Mean plasma concentration-time profile of three rats intravenausly injected with $5 \mathrm{mg}$ BHT/kg in dimethylsulphoxide. Limit of detection $=0.1 \mu \mathrm{g} B H T / m l$. Mean $\pm S E$. 
TABLE 7-I: KINETIC PARAMETERS CALCULATED FRQM INDIVIDUAL PLASMA PROFILES AFTER INTRAVENOUS BHT ADMINISTRATION TO RATS.

\begin{tabular}{|c|c|}
\hline paranmeter & value $(n=3)$ \\
\hline body weight (g) & $315 \pm 54$ \\
\hline$D$ (mg) & $1.58 \pm 0.27$ \\
\hline$A U C$ (ng h/ml) & $320 \pm 60$ \\
\hline Co $(\mu \mathrm{g} / \mathrm{ml})$ & $2.2 \pm 0.7$ \\
\hline $11 / 2(\mathrm{~min})$ & $12 \pm 2$ \\
\hline$V d(1)$ & $1.6 \pm 0.8$ \\
\hline$V \mathrm{~d}(\mathrm{l} / \mathrm{kg})$ & $4.8 \pm 1.6$ \\
\hline$C L(\mathrm{~h} / \mathrm{h})$ & $5.1 \pm 1.5$ \\
\hline$C L(\mathrm{l} / \mathrm{h} \cdot \mathrm{kg})$ & $16.0 \pm 2.7$ \\
\hline
\end{tabular}

BHT ( $5 \mathrm{mg} / \mathrm{kg}$ body weight) was administered in DMSO. Blood was sampled and plasma BHT concentrations were determined as described in Materials \& Methods. Kinetic parameters were calculated according to the equations: $C L=D / A U C$ and $V \mathrm{~d}=\left[C L^{*} t 1 / 2\right] / 0.693$. $A U C \mathrm{~s}$ were determined by the trapezoidal method. Mean $\pm \mathrm{SD}$.

TABLE 7-II: ANALYSIS OF BHT IN FECES AND (UN)CONJUGATED BHT-COOH IN URINE OF MAN AND RAT.

\begin{tabular}{|c|c|c|c|c|c|c|c|}
\hline analyte & source & LOD & day 1 & day 2 & day 3 & day 4 & total \\
\hline Rat: & & & & \\
\hline $\begin{array}{l}\text { BHT-COOH } \\
\text { unconjugated }\end{array}$ & urine & $<0.1 \%$ & $0.5 \pm 0.2$ & $0.3 \pm 0.2$ & $0.2 \pm 0.1$ & $0.1 \pm 0.1$ & $1.0 \pm 0.4$ \\
\hline $\begin{array}{l}\text { BHT-COOH } \\
\text { (un)conjugated }\end{array}$ & urine & $<0.1 \%$ & $0.4 \pm 0.2$ & $0.4 \pm 0.2$ & $0.2 \pm 0.1$ & $0.1 \pm 0.1$ & $1.1 \pm 0.4$ \\
\hline $\mathrm{BHT}$ & feces & $<0.1 \%$ & $7.3 \pm 7.9$ & $2.4 \pm 1.6$ & $0.3 \pm 0.2$ & $0.0 \pm 0.0$ & $9.9 \pm 9.1$ \\
\hline \multicolumn{8}{|l|}{ Man: } \\
\hline $\begin{array}{l}\text { BHT-COOH } \\
\text { unconjuggated }\end{array}$ & urine & $0.1 \%$ & $0.2 \pm 0.1$ & $\mathrm{ND}$ & 。 & - & $0.2 \pm 0.1$ \\
\hline $\begin{array}{l}\text { BHT-COOH } \\
\text { (un)conjugated }\end{array}$ & urine & $0.1 \%$ & $2.6 \pm 2.2$ & $0.0 \pm 0.1$ & - & . & $2.6 \pm 2.2$ \\
\hline $\mathrm{BHT}$ & feces & $3-5 \%$ & $\mathrm{ND}$ & ND & - & - & ND \\
\hline
\end{tabular}

Rats $(n=5)$ received an oral dose of $200 \mathrm{mg} \mathrm{BHT} / \mathrm{kg}$ in corn oil; men $(\mathrm{n}=7)$ ingested $0.5 \mathrm{mg} \mathrm{BHT} / \mathrm{kg}$ dissolved in corn oil. All feces and urine were collected for two (man) or four (rat) days following BHT administration. Analyses were performed as described under Materials \& Methods. Values are expressed as percentage of the dose. $\mathrm{ND}=$ not detectable. $\mathrm{LOD}=$ limit of detection. Mean $\pm \mathrm{SD}$. 

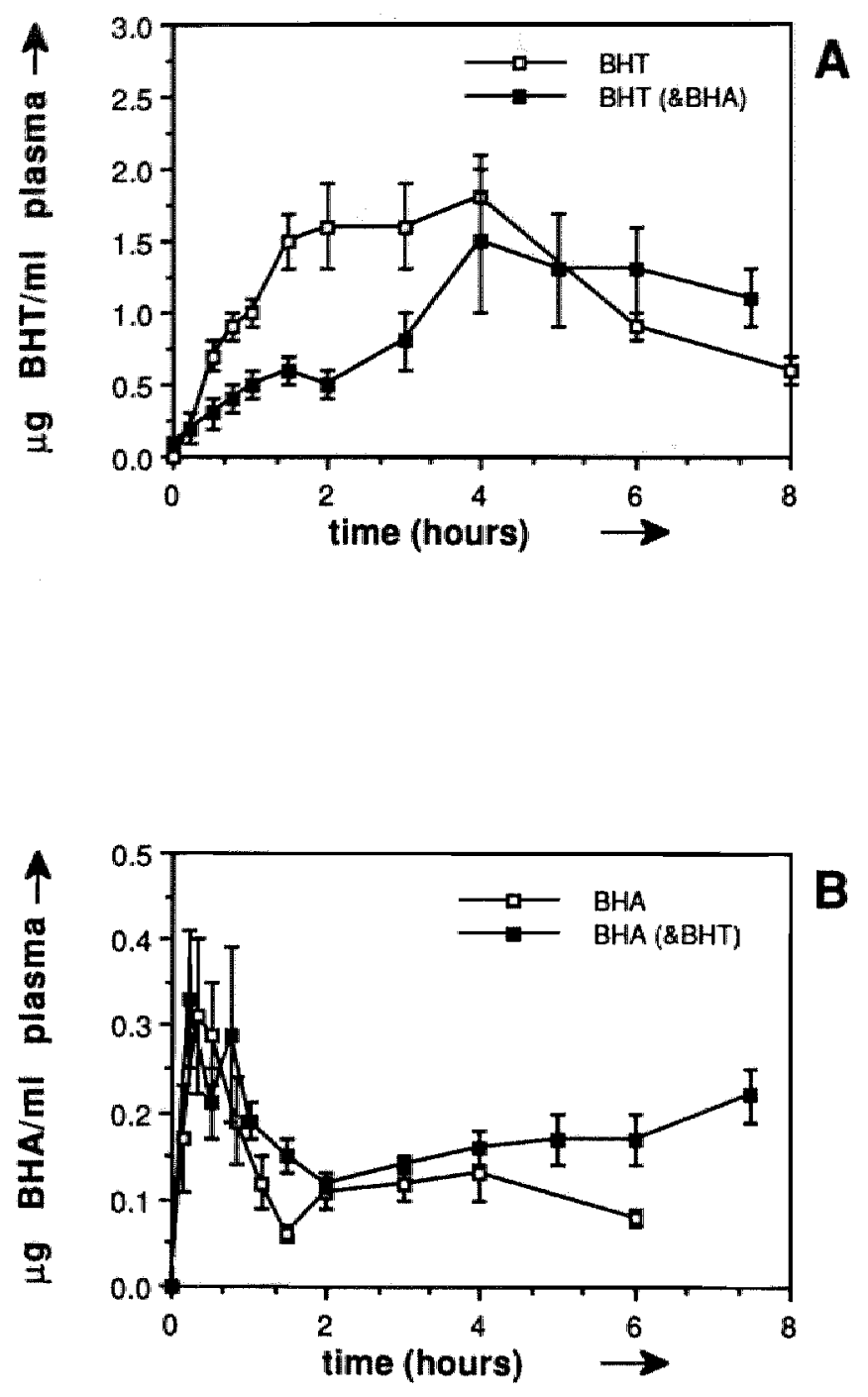

Figure 7-3: Mean plasma concentration-time profiles of BHT (Fig. 7-3a) and BHA (Fig. 7-3b) in rats orally dosed with $200 \mathrm{mg}$ BHT/kg. $200 \mathrm{mg}$ BHA/kg (data from Verhagen et al., 1989), or $200 \mathrm{mg}$ BHT dind 200 mg BHA/kg. Plasma BHT levels were significantly different between 0.5 and 3 hours following administration. Limit of detection for $B H T=0.1 \mu \mathrm{g} / \mathrm{ml}$; limit of detection for $B H A=50 \mathrm{ng} / \mathrm{ml}$. $M e a n \pm S E$. 


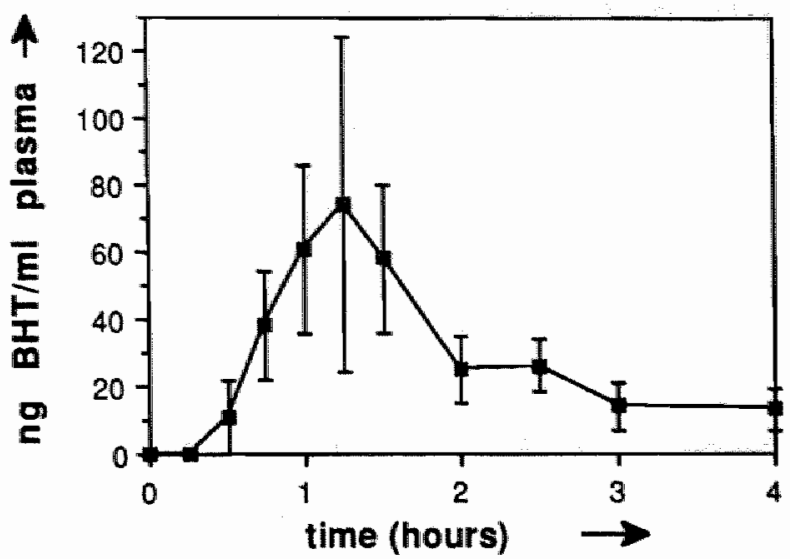

Figure 7-4: Mean plasma concentration-time profile of BHT after aral admimistration of $0.5 \mathrm{mg}$ BITT/kg to seven male volunteers. Limit of detection $=20 \mathrm{ng} B \mathrm{HT} / \mathrm{ml}$. Meam $\pm S E$.
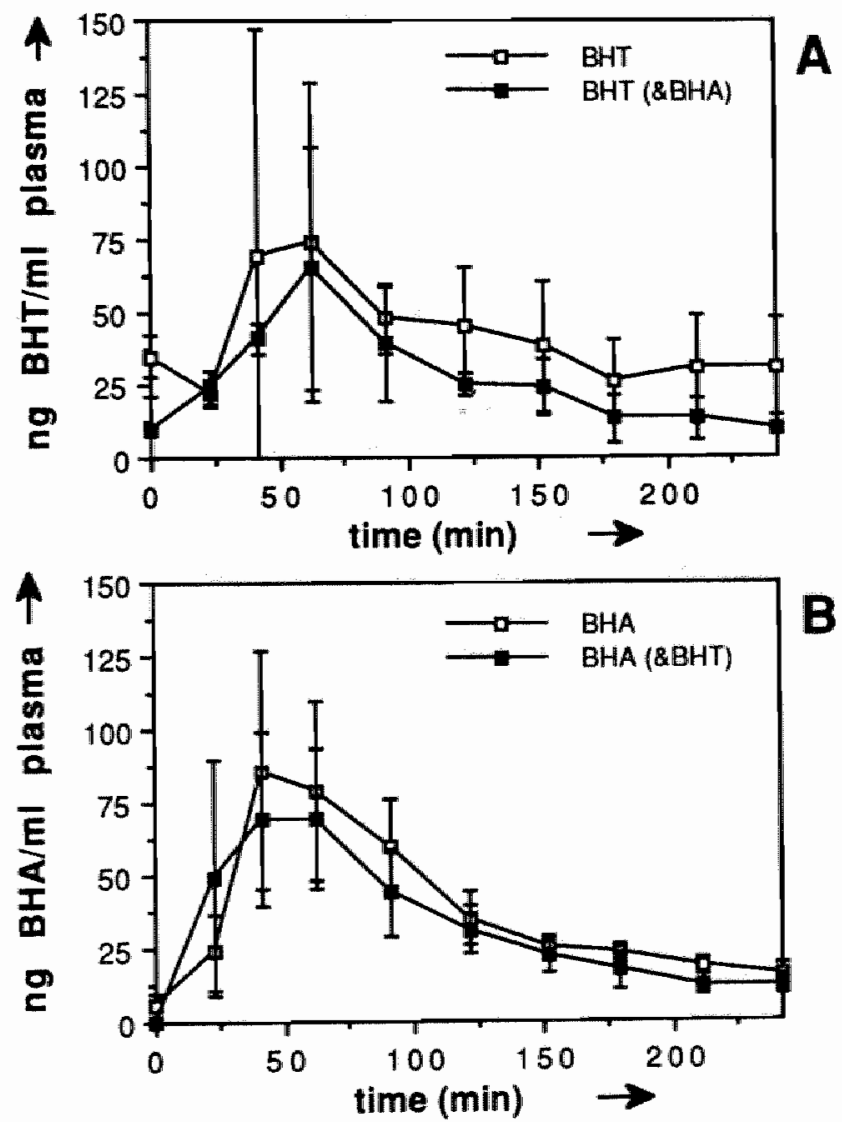

Figure 7-5: Mean plasma concentration-time profiles of BHT (Figure 5a) and BHA (Figure $5^{b}$ ) after oral administration of $0.25 \mathrm{mg} / \mathrm{kg} \mathrm{BHT}$ and $B H A$, alone or in combination, to five female volunteers. Limit of detection $=20 \mathrm{ng} B H T / \mathrm{ml}$ and $10 \mathrm{ng} B H A / \mathrm{ml}$. Mean $\pm S E$. 


\section{Discussion}

Health risk assessment for man based on knowledge of effective concentrations at target tissues is more precise than by a simple comparison of doses (Garattini, 1986; Whittemore et al., 1986). Plasma levels are supposed to be a reflection of concentrations at target tissues. In case of BHA it was concluded that the safety factor implied in calculations of the ADI for man may not be sufficient to prevent harmful effects of BHA as judged from plasma BHA concentrations reached (Verhagen et al., 1989).

The widespread use of BHT as a food additive (Sims and Fioriti, 1980), warrants knowledge on (comparative) kinetics of BHT in man and rat, especially since there is "limited evidence" for the carcinogenicity of BHT itself and BHT has been proven a potent modulator of chemically induced mutagenicity and carcinogenicity (Wattenberg 1985; Ito et al. 1985 "Ito and Hirose, 1987; Anonymous 1986; Kahl 1986; Witschi 1986; Kitchin and Brown, 1987), for which reason the JECFA recently lowered the ADI for BHT from 0-0.5 to $0-0.125 \mathrm{mg} / \mathrm{kg}$ body weight (JECFA, 1986).

Few reports on plasma kinetics of BHT in animals are available (El-Rashidy and Niazi, 1980; Rao and Wong, 1983; Matsuo et al., 1984; Terao et al., 1985). Rao and Wong (1983) reported plasma BHT levels up to $450 \mu \mathrm{g} / \mathrm{ml}$ two hours after an oral dose of $500 \mathrm{mg}$ $\mathrm{BHT} / \mathrm{kg}$ in rats. Matsuo et al. (1984) found plasma ${ }^{14} \mathrm{C}$-BHT levels up to $5 \mu \mathrm{g} / \mathrm{ml}$ following oral doses of $20 \mathrm{mg} 14 \mathrm{C}-\mathrm{BHT} / \mathrm{kg}$ to mice, Terao et al. (1985) reported plasma BHT concentrations below $0.1 \mu \mathrm{g} / \mathrm{ml}$ in rats on a diet containing $0.3 \%$ BHT for several weeks, and El-Rashidy and Niazi (1980) measured plasma BHT levels between 0.1 and 2 $\mu \mathrm{g} / \mathrm{ml}$ in rabbits intravenously injected with $10 \mathrm{mg}$ BHT/ $\mathrm{kg}$. Thus, there appears to be no consistency between plasma levels of BHT reached in experiments with laboratory animals. Plasma BHT concentrations in our study are in range with those reported by others.

In rats, in comparison with BHA (Verhagen et al., 1989) the higher plasma concentrations reached for BHT after oral ingestion of $200 \mathrm{mg} / \mathrm{kg}$ may be a reflection of the smaller $V \mathrm{~d}$ for BHT in rats, since both the $t 1 / 2$ and $C L$ for BHT and BHA were equal. A full comparison between BHT and BHA is complicated by the difference in vehicula used. BHA was administered in a mixture of polyethyleneglycol-400/0.9\% $\mathrm{NaCl}(1 / 1, \mathrm{v} / \mathrm{v})$, in which solvent BHT is not soluble. Instead, BHT was dissolved in DMSO. Kinetic parameters are not corrected for the small difference in molecular weight between BHT and BHA. We could not detect second-order kinetics for BHT, as reported for rabbits by El-Rashidy and Niazi (1980); however, this may be due to the fact that the detection limit $(0.1 \mu \mathrm{g} / \mathrm{ml})$ in our experiments was rather high.

To our knowledge, there are hardly data on plasma BHT kinetics in man. Only Wiebe et al.

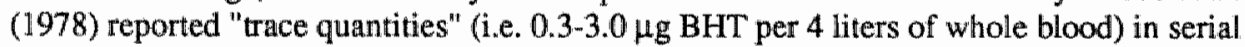
venous blood samples taken during 24 hours following an oral dose of $100 \mathrm{mg}$ BHT in one human volunteer. Our results indicate that mean plasma profiles in man after oral administration of $0.5 \mathrm{mg} / \mathrm{kg}$ BHT (this study) or BHA (Verhagen et al., 1989) are about equal. In this study, plasma BHT levels in rat and man differ largely, generally a factor ten or more. Therefore, concerning toxicity there is probably no reason for questioning the safety factor implied in the assessment of an ADI for human BHT consumption based on plasma BHT concentrations attained. However, the "limited evidence" for carcinogenicity of BHT should be kept in mind. Until the mechanism of the possible carcinogenic response to BHT is understood, the use of BHT as a food additive should be handled carefully. In rats, combined administration of BHT and BHA significantly reduces the uptake of BHT 
in the first hours after antioxidant intake. This is probably not indicative of competitive antioxidant absorption in the gastro-intestinal tract since there was no difference in BHA plasma profiles. In rats, but not in man, these results may be biased, however, by the fact that different methods of analysis have been applied for the determination of BHT, BHA, or

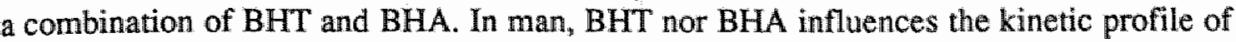
the other food antioxidant on simultaneous administration. Plasma BHA concentrations were well below those reported in a study in which $0.5 \mathrm{mg} / \mathrm{kg}$ was applied (Verhagen et al., 1989), indicating a dose-dependent increase in plasma BHA levels in man. Similar results were seen for BHT.

The metabolism of BHT has been studied thoroughly in laboratory animals and, to a lesser extent, in man (Conning and Phillips, 1986). In rodents, especially in rats, the predominant metabolic pathway involves oxidation of the para-methyl-group finally leading to (conjugated) 3,5-di-tert-butyl-4-hydroxybenzoic acid (BHT-COOH), which is excreted in urine as well as in feces. Also sulphur-containing metabolites have been identified (Daniel et al., 1968; Tajima et al. 1983). More than 43 metabolites were detected in urine and feces of rats and mice following oral administration of ${ }^{14} \mathrm{C}$-BHT (Matsuo et al., 1984). In man, the major route of biotransformation involves oxidation of the tert-butyl side-groups (Daniel et al., 1968; Holder et al., 1970a; Wiebe et al., 1978). Small amounts of BHT were detected in human adipose tissue (Collings and Sharratt, 1970). In man, approximately $50 \%$ of ${ }^{14} \mathrm{C}$ BHT is excreted in urine in the first 24 hours (Daniel et al., 1967). Only small amounts of BHT-COOH $(<2 \%)$ are excreted by man (Daniel et al., 1968; Wiebe et al., 1978) which is in agreement with our results. Excretion of (conjugated) $\mathrm{BHT}-\mathrm{COOH}$ in urine of rats as reported in this study is not consistent however with literature data (Daniel et al., 1968; Matsuo et al., 1984) which showed much higher levels. This discrepancy cannot be explained by differences in rat strains used nor by differences in the doses applied.

In conclusion, plasma concentrations reached after medium to high dosing of BHT in rats and low dosing (ADI) in man are very different. This difference in plasma levels attained indicates that human consumption of BHT at doses corresponding to the ADI may be considered safe, especially since the present ADI is a factor four below the dose used in this study (JECFA, 1986). However, this interspecies comparison does not take a possible carcinogenic potential of BHT into account.

Plasma kinetics of BHT and BHA after ingestion of a single oral dose are about equal in man, but not in rat. In the latter species this is probably due to a difference in $V d$, but not in $t 1 / 2$ or $C L$. In rat, concommitant administration of BHT and BHA leads to a delay in absorption of BHT, but not of BHA, from the gastro-intestinal tract in the first hours. In man, simultaneous oral ingestion of BHT and BHA at a much lower dose does not influence the plasma profiles of these antioxidants as compared to plasma BHT or BHA levels when the antioxidants are administered separately. As already stated by others (Daniel et al., 1968; Wiebe et al., 1978) the metabolism of BHT in rat and man differs too widely to allow a risk evaluation for BHT consumption by man on basis of its metabolism in rats.

\section{Acknowledgements}

Mr. W. Saris, Mr. E. van Dam and Mr. F. Weekers are acknowledged for excellent technical assistance. 


\section{References}

Anonymous (1986). Butylated hydroxytoluene (BHT). IARC Monographs on the evaluation of the carcinogenic risk of chemicals to humans. $40,161-206$.

Babich $\mathrm{H}_{0}$ (1982): Butylated fiydroxyioluene (BHT): a review. Environ. Res. 29: 1.

- Conning D.M. and Phillips J:C. (1986). Comparative metabolism of BHA, BHT and other phenolic antioxidants and its toxicological relevance. Food Chem. Toxicol. $24: 1145-1148$.

Dacre J.C. (1961). The metabolism of 3,5-di-teri-butyl-4-hydroxytoluene and 3,5-di-tert-butyl-4hydroxybenzoic acid in the rabbil. Biochem. J. 78: 758-766.

- Dariel J.W., Gage J.C., Jones D.I., and Stevens M.A., (1967). Excretion of butylated hydroxytoluene (BHT) and butylated hydroxyanisole (BHA) by man. Food. Cosmet. Toxicoll 5: 475-479.

- Daniel J.W., Gage J.C., and Jones. D.I. (1968). The metabolism of 3,5-di-tert-butyl-4-hydroxytoluene in the rat and in man. Biochem. $J$, $106: 783-790$.

- El-Rashidy A. and Niazi S. (1980). Comparative pharmacokinetics of butylated hydroxyanisole and butylated hydroxytoluene in rabbits.J. Pharm. Sci. 69: 1455-1457.

- Garattini S. (1986). Toxic effects of chemicals: difficulties in extrapolating data from animals to man. CRC Crit. Rev. Toxicol. 16: 1-20.

- Golder W.S., Ryan A.J., and Wright S.E. (1962). The urinary excretion of tritiated butylated hydroxyanisole and butylated hydroxytoluene in the rat. J. Pharm. Pharmacol. 14: 268-271.

Hagemani $G J_{*}$, Verhagen $H_{n}$ and Kleinjans J.C.S. (1988). Butylated hydroxyanisole, butylated hydroxytoluene and tert-butylhydroquinone are not mutagenic in the Salmonella/microsome assay using new tester strains. Mut. Res: 208: 207-211.

- Hirose M., Shibata M., Hagiwara A., Imaida K. and Ito N. (1981). Chronic toxicity of butylated hydroxytoluene in Wistar rats. Food Cosmet. Toxicol. $19: 147-151$.

- Hirose M., Masuda A., Kurata Y., Ikawa E., Mera Y. and Ito N. (1986). Histologic and autoradiographic studies on the forestomach of hamsters treated with 2-tert-butylated hydroxyanisole, 3-tert-butylated hydroxyanisole, crude butylated hydroxyanisole or butylated hydroxytoluene. J. Natl. Cancer Inst. 76: 413-149.

- Holder G.M., Ryan A.J., Watson T.R., Wiebe L.I. (1970a) The metabolism of butylated hydroxytoluene, (3,5-di-l-butyl-4-hydroxytoluene) in man. J. Pharm. Pharmacol. 22: 375-376.

- Holder G.M., Ryan A.J., Watson T.R., and Wiebe L.I. (1970b). The biliary metabolism of butylated hydroxytoluene, (3,5-di-t-butyl-4-hydroxytoluene) and its derivatives in the rat. J. Pharm. Pharmacol. 22: $832-838$.

- Ito N., Fukushima S. and Tsuda H. (1985). Carcinogenicity and modification of the carcinogenic response by BHA, BHT and other antioxidants. CRC Crit. Rev. Toxicol. 15: 109-150.

- Ito N. and Hirose M. (1987). The role of antioxidants in chemical carcinogenesis. Gann 78: 1011-1026.

- Joint FAO/WHO Expert Committee on Food Additives (1986). Toxicological evaluation of certain food additives and contaminants. Bulylated hydroxytoluene (BHT). WHO Food Add. Ser. 21: 25-46.

- Kahl R. (1986). The dual role of antioxidants in the modification of chemical carcinogenesis. $J$. Environ. Sci. Health C4(1)" 47-92.

- Kitchin K.T. and Brown J.L. (1987). Biochemical effects of two promotors of hepatocarcinogenesis in tats. Food Chem. Toxicol. 25:603-607.

- Lindenschmidt R.C., Tryka A.F., and Witschi H.P. (1987). Modification of gastrointestinal tumor development in rats by dietary butylated hydroxytoluene. Fundam. Appl. Toxicol. 8: 474-481.

- Malkinson A.M. (1983). Review: putative mutagens and carcinogens in foods. III. butylated hydroxytoluene (BHT), Environ. Mutagenesis 5: 353-362.

- Marino A.A. and Mitchell I.T. (1972). Lung damage in mice following intraperitoneal injection of butylated hydroxytoluene. Proc. Soc. Exp. Biol. Med. 140: 122-125.

- Matsuo M., Mihara K., Okuno M., Ohkawa H., and Miyamoto J. (1984). Comparative metabolism of 3,5-di-tert-butyl-4-hydroxytoluene (BHT) in mice and rats. Food Chem. Toxicol. 22: 345-354.

- Nakagawa $Y_{*,}$ Tayama K., Nakao $T_{.,}$and Hiraga K. (1984). On the mechanism of butylated hydroxytoluene-induced hepatic toxicity in rats. Biochem. Pharmacol. 33: 2669-2674.

- Olsen P., Meyer O., Bille N.. and Wurtzen G. (1986). Carcinogenicity study on butylated hydroxytoluene (BHT) in Wistar rats exposed in utero. Food Chem. Toxicol. 24: 1-12.

- Patterson R.M., Keith L.A. and Stewart J. (1987). Increase in chromosomal abnormalities in chinese hamster ovary cells treated with butylated hydroxytoluene in vitro. Toxicol. In Vitro 1: 55-57. 
- Rao A.V. and Wong G.K.K. (1983). Effects of dietary protein on the pharmacokinetics of butylated hydroxytoluene (BHT) in rats. Drug-Nutr. Interact. 2: 69-77.

- Sims R.J. and Fioriti J.A. (1980). in T.E. Furia (editor) CRC Handbook or Food Additives, Vol. II, Chemical Rubber Co., Boca Raton, FL, 2nd ed.: pl3.

- Tajima K., Yamamoto K, and Mizutani T. (1983). Identification and determination of glutathione and glucuronide conjugates formed from butylated hydroxytoluene in rats. Chem. Pharm. Bull. 31: 3671 3677.

- Takahashi O. and Hiraga K., (1980). Excretion of dietary butylated hydroxytoluene by the rat. Toxicol. Lett. $6: 287-292$.

- Terao J., Magarian R.A., Brueggemann G. and King M.M. (1985). Methods of extraction and highperformance liquid chromatographic analysis of butylated hydroxytoluene from the tissues and serum of rats. Anal. Biochem. 151: 445-454.

- Verhagen H., Thijssen H.H.W., and Kleinjans J.C.S. $\left(1987^{\mathrm{a}}\right)$. Determination of butylated hydroxytoluene in plasma by high-performance liquid chromatography. J.Chromatogr. 422: 288-293.

- Verhagen H., Thijssen H.H.W., and Kleinjans J.C.S. (1987b). Sensitive high-performance liquid chromatogtaphic method for the routine determination of butylated hydroxyanisole in plasma. $\mathbf{J}$. Chromatogr. 413: 282-286.

- Verhagen H., Thijssen H.H.W., ten Hoor F. and Kleinjans J.C.S. (1989) Disposition of single oral doses of butylated hydroxyanisole in man and rat. Food Chem. Toxicol. 27: 151-158.

- Wattenberg L.W. (1985). Chemoprevention of cancer. Cancer Res. 45: 1-8.

- Whittemore A., Grossner S.C., and Silvers A. (1986). Pharmacokinetics in low dose extrapolation using animal cancer data. Fundam. Appl. Toxicol. 7: 183-190.

- Wiebe L.1., Mercer J.R., and Ryan A.J. (1978). Urinary metabolites of 3,5-di-(1-[ $\left.{ }^{13} \mathrm{C}\right]$ methyl-1methylethyl)-4-hydroxytoluene (BHT-13 C) in man. Drug Metab. Disp. 6: 296-297.

- Witschi H.P. (1986). Enhanced tumour development by butylated hydroxytoluene (BHT) in the liver, lung and gastro-intestinal tract. Food Chem. Toxicol. 24: 1127-1130. 

PART III

A HUMAN TOXICITY STUDY WITH BHA 



\title{
Chapter 8
}

\section{Effect of subacute oral intake of the food antioxidant butylated hydroxyanisole on clinical parameters and phase-I and -II biotransformation capacity in man}

\author{
Hans Verhagen, Lou M.Maas, Rico H.G. Beckers, Henk H.W. Thijssen, \\ Foppe ten Hoor, Peter Th. Henderson and Jos C.S. Kleinjans
}

Human Toxicology, in press

\section{Abstract}

A study is presented in which eight healthy male non-smoking volunteers ingested a daily amount of $0.5 \mathrm{mg} / \mathrm{kg}$ butylated hydroxyanisole (BHA) for ten consecutive days. Blood samples were taken on days -6 and 0 before and on days 4 and 7 after the first BHA administration for the assessment of standard clinical plasma parameters (L-aspartate-aminotransferase, L-alaninaminotransferase, L-gamma-glutamyltranspeptidase, creatine phospho kinase, lactate dehydrogenase, total protein, albumin, urea, creatinine, $\mathrm{Na}^{+}$, and $\mathrm{Cl}^{-}$). Antipyrine (500 $\mathrm{mg}$ p.o.) and paracetamol (500 $\mathrm{mg}$ p.o.) were administered before and during BHA administration as test substances to measure phase-I and phase-II biotransformation capacity. Saliva samples and urine were subsequently collected for the assessment of kinetic parameters (e.g. saliva elimination half life, saliva clearance, apparent volume of distribution) and urinary excretion of metabolites. Kinetic plasma parameters of BHA itself were determined in plasma samples obtained via a catheter in an arm vein after oral BHA intake on days 0 and 7. Levels of antipyrine, paracetamol, BHA and metabolites in plasma, saliva or urine were quantified by standard or newly developed reversed-phase highperformance liquid chromatography methods. Urinary excretion of $\mathrm{Na}^{+}$, $\mathrm{K}^{+}$, and $\mathrm{Cl}^{-}$, as well as osmolality of urine were measured on three days before and six days during BHA administration.

Generally, no significant differences were detected in the parameters measured, indicating that oral administration of BHA to men for ten days remains without effects on clinical biochemical parameters and phase-I and . II biotransformation capacity. In contrast, urinary excretion of metabolites of BHA was significantly increased on days 3 and 7 vs the first day of BHA administration. This may either result from an induction or inhibition of BHA-specific phase-I and -II metabolizing enzymes in man, or from a bioaccumulation of BHA and/or its metabolites in the body. 


\section{Introduction}

The synthetic phenolic food antioxidant butylated hydroxyanisole (BHA) is used widely to prevent oils, fats and shortenings from oxidative deterioration (1). BHA is classified as a GRAS (generally regarded as safe)-compound by the US Food and Drug Administration (2). Recently, however, it was shown to act as a complete carcinogen in the forestomach of rodents (3-6). The carcinogenic effects of BHA are dose-dependent and involve hyperplasia, papillomas and carcinomas (7). These changes are accompanied by an increase in forestomach labelling index (i.e. the percentage of DNA-synthesizing cells) and by alterations in other cell kinetic parameters $(8,9)$. Further, BHA has a modulating effect on chemically induced mutagenesis and carcinogenesis, exhibiting both pro- as well as antigenotoxic properties $(2,4,10-15)$. These latter effects are, at least in part, thought to result from modifications of phase-I and phase-II biotransformation enzyme systems.

Indeed BHA is capable of influencing the biotransformation of various xenobiotics in vitro and in vivo, either by enzyme induction and/or inhibition $(15,16,17)$.

Plasma concentrations are assumed to be a reflection of effective concentrations of a substance at target tissues and thus have been suggested to constitute a more physiological basis for health risk assessment in man as compared to dose analysis $(18,19)$. In a recent publication, we showed that a single oral dose of $200 \mathrm{mg} / \mathrm{kg}$ in rat, which dose has appeared to be close to the no effect level (NEL) in animal toxicity and carcinogenicity-related studies $(7,8,20)$, and $0.5 \mathrm{mg} \mathrm{BHA} / \mathrm{kg}$ in man resulted in plasma BHA concentrations within one order of magnitude of each other, thereby questioning the safety margin for the determination of the ADI for human BHA consumption (21).

Moreover, in the same study (21), in man only about $50 \%$ of the administered dose was recovered from urine over the first four days following administration, while no BHA could be detected in feces collected during the same period, indicating the possibility of a prolonged retention of BHA in the body.

For these reasons a study was prompted to investigate the effects of human BHA intake on both phase-I and -II biotransformation capacity. For this purpose, a group of eight healthy male non-smoking volunteers ingested daily a dose of $0.5 \mathrm{mg} \mathrm{BHA} / \mathrm{kg}$ for ten days. Human biotransformation capacity was determined by ewaluating the biological fate of the analgesics antipyrine (AP) and paracetamol ( $\mathrm{PC}$ ), used as test substances before and during $\mathrm{BHA}$ intake. In addition, possible effects of BHA on the plasma kinetics and metabolism of BHA itself was examined on three days during the ingestion period. Further, blood samples were taken before and during $\mathrm{BHA}$ intake in order to assess clinical plasma parameters.

\section{Materials and Methods}

\section{Materials}

Food-grade BHA (a mixture of isomers containing 93 \% 3-tert-butyl-4-hydroxyanisole) was a gif from $\mathrm{J}$. Dekker Co. (Wormerveer, The Netherlands). Paracetamol (PC; Panadol ${ }^{9}$ ) was commercially obtained. Antipyrine (AP) and phenacetin were obtained wia the dispensary of the Maastricht Academic Hospital. 3Hydrox ymethylantipyrine (HMA) was a giff from Prof.Dr. D.D. Breimer and Dr. M. Darhof, University of Leiden, "The Netherlands. Norantipyrine (NORA) and 4-hydroxyantipyrime (OHA) were obtained from Aldrich (Brussels, Belgium ). Limpet acetone powder type I was from Sigma (St. Louis, MO, USA). For highperformance liquid chromatography (HPLC), only HPLC-grade solwents were used. Water was filtered through a Milli-Q water purification system (Millipore, Molsheim, France). Analytical reagent grade chemicals were used in all other instances. 
Analytical procedures

Plasma BHA concentrations were determined as described previously (22). Levels of (un)conjugated BHA and its metabolite (un)conjugated tert-butyl-hydroquinone (TBHQ) in urine were determined as previously reported (21), with minor modifications. Following owemight deconjugation of BHA and TBHQ at $37^{\circ} \mathrm{C}$ with limpet acetone powder type I, BHA and TBHQ were determined in one run, using trimethylhydroquinone as an internal standard and methanol/water/acetic acid $(53 / 46 / 1, \mathrm{v} / \mathrm{v} / \mathrm{v})$ as the eluent. Flow was $2 \mathrm{ml} / \mathrm{min}$; the internal standard, TBHQ and BHA eluted after $1.5,2.5$ and $7.4 \mathrm{~min}$, respectively. No distinction was made between free (=unconjugated) - BHA and -TBHQ and conjugates of BHA and TBHQ with glucuronic acid or sulphate, since in a previous study (21) mo unconjugated BHA or TBHQ could be determined in human urine.

The method for the measurement of salivary levels of PC was slightly modified from Miners et al. (23). A $1.0 \mathrm{ml}$ aliquot of saliva was mixed with $1.0 \mathrm{ml}$ of $20 \%$ trichloroacetic acid. After centrifugation, $20 \mu$ ll of the clear supernatant was injected onto a LiChrosorb 5-RP-18 column $(100 \times 4.6 \mathrm{~mm})$. The mobile phase was water/acetonitril/acetic acid $(94.5 / 4.5 / 1, \mathrm{v} / \mathrm{v} / \mathrm{v})$. Flow was $1.5 \mathrm{ml} / \mathrm{min} ; \mathrm{PC}$ eluted after $3.4 \mathrm{~min}$. Urinary concentrations of paracetamol-glucuronide (PC-G) and paracetamol-sulphate (PC-S) were assessed according to Miners et al. (24).

The methodology for the determination of salivary AP levels was adapted from Campbell ct al. (25) and Teunissen et al. (26). Saliva $(0.4 \mathrm{ml})$ and methanol $(1.6 \mathrm{ml}$, containing $3 \mu \mathrm{g}$ phenacetin/ $\mathrm{ml}$ as an internal standard) were mixed vigorously for $10 \mathrm{sec}$. After centrifugation for $10 \mathrm{~min}$ at $2000 \mathrm{~g}, 20 \mu \mathrm{l}$ of the supernatant fraction was injected onto a LiChrosorb 5-RP-18 $(150 \times 4.6 \mathrm{~mm})$ HPLC column. The mobile phase consisted of acetonitrile/0.05 $\mathrm{M}$ Tris- $\mathrm{HCl}$ buffer $\mathrm{pH} 7.6(27 / 73, \mathrm{w} / \mathrm{v})$; flow was $1.5 \mathrm{ml} / \mathrm{min}$. Uluraviolet light absorption of the effluent was measured at $254 \mathrm{~nm}$. AP and phenacetin eluted after 3.0 and 4.6 min respectively.

The protocol of Teunissen ct al. (26) was applied to determine urinary levels of AP and its metabolites HMA, NORA and OHA. NORA and OHA were determined separately from AP and HMA.

Clinical biochemical plasma parameters were determined as a routine procedure on a centrifugal analyzer (type Cobas Bio, Hoffmann La Roche) and included the enzymes L-aspartate-aminotransferase (EC. 2.6.1.1.), Lalanine-aminotransferase (EC. 2.6.11.2.), L-gamma-glutamyltranspeptidase (EC. 2.3.2.2.), creatine phosphokinase (EC. 2.7.3.2.), lactate dehydrogenase (EC. 1.1.1.27.), as well as total protein, albumin, urea and creatinine. Levels of $\mathrm{Na}^{+}$and $\mathrm{K}^{+}$in urine or plasma were determined on an Instrumentanion Laboratory 243 flame photometer (Pademo Dugnano, Italy). $\mathrm{Cl}^{-}$was measured on an Eppendorf 6610 chlorinemeter (Hamburg, FRG). Osmolality of urine was determined with an Osmomat $030 \mathrm{cryoscopic}$ osmometcr (Gonotec, Berlin, FRG).

Tests

The BIIA-test was conducted as described previously (21). In short, after fasting overnight, volunteers ingested a gelatin capsule containing $0.5 \mathrm{mg} \mathrm{BHA} / \mathrm{kg}$ body weight as a solution of $10 \%$ in corn oil, which was prepared in our laboratory. From time zero up to four hours following ingestion, scrial venous blood samples $(5 \mathrm{ml})$ were withdrawn from a cathetcr placed in an arm vein and collecled into heparanized containers. Plasma was separated from cells by centrifugation for $10 \mathrm{~min}$ at $2000 \mathrm{~g}$. Urine was collected for 24 hours. Plasma and urine were stored at $-20^{\circ} \mathrm{C}$ until analysis.

The paracetamol-test followed the protocol of Miners et al. (23). In short, after fasting overmight ${ }_{\mathrm{m}}$ volunteers ingested $500 \mathrm{mg}$ paracetamol with a glass of mineral water, followed by mouth washes with tap water. Saliva was collected prior to and up to eight hours after drug administration. Saliva production was stimulated by chewing on a piece of parafillm $(27,28)$. Saliwa samples were stored at $-20^{\circ} \mathrm{C}$ until analysis. Urine was collected for 0-8 hours and 8-24 hours. Urinary volume was measured and aliquots of urine were analyzed immediately.

The antipyrine-test was performed as described by Danhof et al. (28). In short, after an overnight fast, volunteers ingested $500 \mathrm{mg}$ antipyrine dissolved in about $100 \mathrm{ml}$ mineral water, followed by seweral mouth washes with tap water. Saliva collection during 48 hours following antipyrine intake was performed similarly to the paracetamol-test. Samples were stored at $-20^{\circ} \mathrm{C}$ until analysis. Urine was collected on sodium pyrosulphite for $0-24$ and $24-48$ hours. Urinary wolume was measured and aliquots of urine were stored at $-20^{\circ} \mathrm{C}$. For analysis, urine samples of $0-24$ and $24-48$ hours were pooled. 
No eating was allowed in any of the three test protocols described until one hour after drug intake.

\section{Experimental protocol}

Eight healthy non-smoking male volunteers $(23+5$ years; $74+6 \mathrm{~kg}$; mean $+\mathrm{SD}$ ) were recruited from the student population of the University of Limbarg. Two months before the onset of the experiments volunters were subjected to a medical examination. Blood samples $(10 \mathrm{ml})$ were taken during this examination for the measurement of standard biochemical and hematological plasma parameters. All volunteers were found healthy and suilable for participation in the experiment. The test-protocol was approved by the Medical Ethical Commission of the University of Limburg and all volunteers signed informed consent to it previously. Volunteers were not subjected to any restriction in their life style during the experiment, except that no paracetamol-containing analgesics were allowed during the paracetamol-test period.

In the first week (day -6 and -5 ) the paracetamol- and antipyrine-tests were conducted. From day 0 to day' 9 , each subject ingested $0.5 \mathrm{mg}$ BHA/kg body weight before having breakfast, except on days 0 and 7 when -as part of the BHA-test- BHA was administered only after the first venous blood sample was taken. In the last week the paracetamol- and antipyrinetests were repeated concommitant with BHA intake (day 8 and 9). Blood was sampled for the determination of clinical biochemical plasma parameters on days $-6,0,4$ and 7 , centrifuged for $10 \mathrm{~min}$ at $2000 \mathrm{~g}$ and plasma stored at $-80^{\circ} \mathrm{C}$ until analysis. Clinical plasma parameters were determined on day 9, on which dlay all samples were analyzed to avoidl possible analytical day to day variations. A detailed survey of the experimental protocol is presented in Table 8-1.

TABLE 8-I: DAY TO DAY PROTOCOL FOR THE DETERMINATION OF THE INFLUENCE OF 10 DAYS OF ORAL BHA INTAKE BY EIGHT MALE VOLUNTEERS ON CLINICAL PLASMA PARAMETERS AND PHASE-I AND -II METABOLIC CAPACITY.

\begin{tabular}{|c|c|c|c|c|c|}
\hline day & BHA-intake & blood sampling $b$ & BHA-test $L^{C}$ & PC-test ${ }^{d}$ & AP-teste \\
\hline-6 & & + & & + & \\
\hline-5 & & & & & + \\
\hline \multicolumn{6}{|l|}{.4} \\
\hline \multicolumn{6}{|l|}{-3} \\
\hline \multicolumn{6}{|l|}{-2} \\
\hline \multicolumn{6}{|l|}{-1} \\
\hline 0 & + & + & + & & \\
\hline 1 & + & & & & \\
\hline 2 & + & & & & \\
\hline 3 & + & & + & & \\
\hline 4 & + & * & & & \\
\hline 5 & + & & & & \\
\hline 6 & + & & & & \\
\hline 7 & + & + & + & & \\
\hline 8 & + & & & + & \\
\hline 9 & + & & & & + \\
\hline 10 & & & & & \\
\hline
\end{tabular}

$+=$ performed.

a: $0.5 \mathrm{mg}$ BHA/kg body weight before breakfast;

b: 5 mill venous blood;

c: Serial venous blood samples were taken between 0 and 4 hours following oral BHA intake; urine was sampled for 24 hours:

d: $500 \mathrm{mg}$ paracetamol p.o.; saliva samples were collected for 8 hours; urine was collected for 24 hours;

e: $500 \mathrm{mg}$ antipyrine p.o.: saliva samples and urine were collected for 48 hours.

f: Only urine was collected for 24 hours. 
Analysis of results

Apparent first-order elimination rate constants $(k e)$ were calculated from the individual saliva or plasma concentration-time curves by linear least squares regression analysils using experimental data points from the descending parts of the curves. Plasma/saliva elimination half life $(n 1 / 2)$ was determined as $11 / 2=$ $0.693 / k e$. The area under the plasma/saliva concentration time curve (AUC) was determined by the trapezoidal rule and extrapolated to infinity. Plasma/saliva clearance $(C L)$ was calculated from the model. independent equation as $C L=D o s e / A U C$, assuming complete absorption.

The apparent volume of distribution $(V \mathrm{~d})$ was calculated as $V \mathrm{~d}=C L * 0.693 / t 1 / 2$. For better comparison, parameters may be expressed per $\mathrm{kg}$ body weight on instances. Metabolite formation of BHA, $\mathrm{PC}$ and $\mathrm{AP}$ is expressed as percentage of the dose administered and as partial CL of the parent compound according to the equation:

$C L_{\text {metabolite }}=C L_{\text {parent }}$ compound ${ }^{*}$ dose metabolite $^{*} 10^{-2}$, assuming that the metabolites are excreted completely into urine and are not further metabolized by other unknown pathways.

Results are presented as mean + SD. The significance of differences between data was calculated with Student's-t-test for paired samples; $\mathrm{p}<0.05$ is considered significant.

\section{Results}

Results on kinetic parameters measured in the AP- and PC-tests are summarized in Table 8II. Saliva $t 1 / 2$ 's were about two and ten hours for $\mathrm{PC}$ and $\mathrm{AP}$, respectively, before as well as during the time of BHA administration. Mean saliva $C L$ was about 1 and $5 \mathrm{ml} / \mathrm{min} / \mathrm{kg}$ body weight for $\mathrm{AP}$ and $\mathrm{PC}$, respectively. The $V \mathrm{~d}$ was 70 liter/person, on average, in all instances. Urinary metabolite profiles for AP and PC are shown in Figure 8*1. Dose recovery of $\mathrm{PC}$ was little over $100 \%$, which may have been due to inaccuracies in the determination of PC-G, since this compound could not fully be separated from other peaks in the HPLC-chromatograms, a phenomenon that was also met by Miners et al. (23). Mean dose recovery of AP is less than $100 \%$, as also reported by others $(28-30)$, which is due to other, in part unknown, pathways of biotransformation of AP in man. One minor metabolite of AP in man (3-carboxy-antipyrine), accounting for about $5 \%$ of metabolites, was not determined. The partial $C L$ for production of OHA was $0.30 \pm 0.10 \mathrm{ml} / \mathrm{min} / \mathrm{kg}$ before and $0.33 \pm 0.12 \mathrm{ml} / \mathrm{min} / \mathrm{kg}$ during the period of BHA administration. These values were $0.22 \pm$ 0.08 and $0.21 \pm 0.07 \mathrm{ml} / \mathrm{min} / \mathrm{kg}$ (NORA), $0.17 \pm 0.08$ and $0.17 \pm 0.06 \mathrm{ml} / \mathrm{min} / \mathrm{kg}$ (HMA), $0.03 \pm 0.02$ and $0.04 \pm 0.02 \mathrm{ml} / \mathrm{min} / \mathrm{kg}(\mathrm{AP}), 1.9 \pm 0.5$ and $2.1 \pm 0.6 \mathrm{ml} / \mathrm{min} / \mathrm{kg}(\mathrm{PC}-\mathrm{S})$, $3.1 \pm 1.4$ and $3.7 \pm 0.6 \mathrm{ml} / \mathrm{min} / \mathrm{kg}(\mathrm{PC}-\mathrm{G})$ for the period before and during $\mathrm{BHA}$ administration, respectively. None of the differences in the clearance for the production of the metabolites were statistically significant.

Results on kinetic plasma parameters for BHA are presented in Table 8-III. Since in the latter test extrapolation to infinity of the $A U C$ was sometimes prone to inaccuracy (i.e. the estimated extra part of the $A U C$ was more than $10 \%$ ) more parameters are presented. As reported previously (21), plasma BHA $t 1 / 2$ was about one hour. Differences between day 0 and day 7 were statistically not significant.

Urinary excretion of (un)conjugated BHA and its $\mathrm{O}$-demethylated metabolite (un)conjugated TBHQ on days 0,3 and 7 of BHA administration is shown in Figure 8-2. Since in a previous experiment no unconjugated BHA or TBHQ could be detected in human urine after oral ingestion of $0.5 \mathrm{mg} \mathrm{BHA} / \mathrm{kg}$ body weight, only the total amount of (un)conjugated BHA and TBHQ was determined. Results indicate a gradual increase in excretion of (un)conjugated BHA from $52 \pm 16 \%$ on day 0 , to $75 \pm 12 \%$ on day 7 . Urinary excretion of (un)conjugated TBHQ is $7.4 \pm 1.8 \%, 10.5 \pm 3.1 \%$ and $13.0 \pm 3.9 \%$ of the dose on days 0 , 3 and 7 respectively, indicating a significant elevation of excretion of this metabolite on day 
7 vs. day 0 . Overall urinary content of $\mathrm{BHA}$-metabolites was $60 \pm 17 \%, 72 \pm 29 \%(\mathrm{p}>0.05$ vs day 0 ) and $88 \pm 12 \%$ ( $<<0.005$ vs day 0 ) on days 0,3 and 7 , respectively. The ratio TBHO/BHA (0.17 on average) in urine was at no moment significantly altered. The partial $C L$ of (un)conjugated BHA was $25 \pm 4$ and $35 \pm 11 \mathrm{ml} / \mathrm{min} / \mathrm{kg}$ on days 0 and 7 , respectively $(P>0.05$ ); the partial $C L$ of (un)conjugated TBHQ was $3.9 \pm 1.3$ and $7.3 \pm 3.2$ $\mathrm{ml} / \mathrm{min} / \mathrm{kg}$ on days 0 and 7 , respectively $(\mathrm{P}<0.05)$.

Biochemical plasma parameters were not significantly altered on day 4 and 7 of BHA intake as compared to days -6 and 0 before BHA administration. No largely aberrant results from standard values were measured. Values for plasma $\mathrm{K}^{+}$concentrations are not reported since blood samples contained abnormally high $(>18 \mathrm{mEq} / 1) \mathrm{K}^{+}$levels, indicating some loss of intracellular $\mathrm{K}^{+}$, probably due to cell lysis. Although $\mathrm{Na}^{+}$and $\mathrm{Cl}^{-}$levels on day -6 are slightly but significantly lower as compared to days 4 and 7 , there was no difference in these parameters between day 0 and days 4 and 7 . We have no explanation for this discrepancy. Since there was no difference in plasma electrolyte levels on day 0 (before BHA administration) vs days 4 and 7 (during BHA intake), it is concluded that also these parameters are not altered by subacute BHA ingestion. Results are summarized in Table 8 IV.

TABLE 8-II: KINETIC PARAMETERS FOR PHASE-I AND -II METABOLIC CAPACITY IN MAN CALCULATED FROM INDIVIDUAL SALIVA CONCENTRATION-TIME CURVES OF THE TEST SUBSTANCES AP AND PC.

parameter before BHA intake value during BHA intake
(control value)

\begin{tabular}{lll}
\hline A.P $t 1 / 2$ (hours) & $10.3 \pm 2.8$ & $9.0 \pm 1.6$ \\
AP CL (ml/min*kg) & $1.1 \pm 0.3$ & $1.2 \pm 0.3$ \\
AP Vd (1/kg) & $0.96 \pm 0.19$ & $0.94 \pm 0.26$ \\
& & \\
PC $t / 2$ (hours) & $2.2 \pm 0.3$ & $2.0 \pm 0.5$ \\
PC $C L\left(\mathrm{ml} / \mathrm{min}^{*} \mathrm{~kg}\right)$ & $5.2 \pm 1.3$ & $5.4 \pm 1.1$ \\
PC Vd $(\mathrm{l} / \mathrm{kg})$ & $0.96 \pm 0.21$ & $0.90 \pm 0.25$
\end{tabular}

Values are expressed as mean \pm SD for seven individuals. (One volunteer did not participate in the AP-test. One person did not collect sufficient amounts of saliva in the PC-test.) Volunteers ingested $500 \mathrm{mg}$ AP or PC before or during subacute BHA administration. Absorption of $\mathrm{AP}$ and $\mathrm{PC}$ is assumed to be complete. Tests were performed on days -6 and $8(\mathrm{PC}$ ) and -5 and 9 (AP). Differences are statistically not significant.

Urinary excretion of electrolytes is indicated in Figure 8-3. No significant differences were found on days 8,9 and 10 as compared to days $-6,-5$ and -4 , respectively. Urine collected in the AP-test contained $3 \mathrm{~g}$ sodium pyrosulphite/day, added to stabilize AP and its metabolites, which in consequence increases natural $\mathrm{Na}^{+}$levels in and osmolality of urine. As sodium pyrosulphite was added to stabilize AP-test urine both before and during the period of BHA intake, no corrections were made for the addition of sodium pyrosulphite on $\mathrm{Na}^{+}$content or osmolality. Data from urine samples obtained on days 0,3 and 7 do not differ from data on days -6 or 8 , on which days no chemicals were added to urine. Mean osmolality of urine samples was also not different on any day (results not shown). 


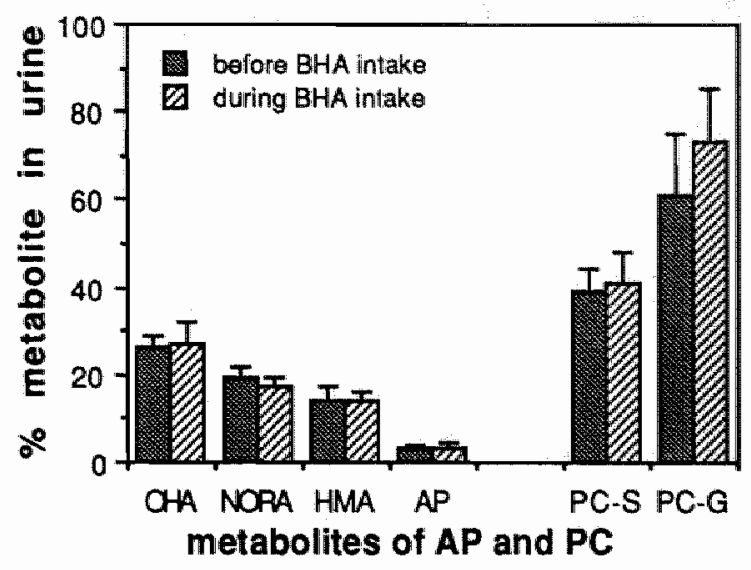

Figure 8-1: Urinary excretion profile of metabolites of the phase-I and -II biotransformation test substances $A P$ and $P C$, both before and during daily $B H A$ administration. Values are expressed as percentage of the dose administered. Mean $\pm S D$. No significant differences were found.

TABLE 8-III: KINETIC PARAMETERS FOR BHA DISPOSITION CALCULATED FROM INDIVIDUAL PLASMA CONCENTRATION-TIME CURVES.

parameter

value on day 0

walue on day 7

of BHA intake

of BHA intake

\begin{tabular}{|c|c|c|}
\hline $11 / 2(\mathrm{~min})$ & $61 \pm 9$ & $56 \pm 4$ \\
\hline $\mathrm{CL}(\mathrm{ml} / \mathrm{min} / \mathrm{kg})$ & $47 \pm 11$ & $61 \pm 34$ \\
\hline$V \mathrm{~d}(1 / \mathrm{kg})$ & $4.2 \pm 1.5$ & $6.1 \pm 2.8$ \\
\hline$A U C_{0-4 h^{a}}\left(\mathrm{ng}{ }^{*} \mathrm{~h} / \mathrm{ml}\right)$ & $161 \pm 44$ & $103 \pm 49$ \\
\hline peak conc $(\mathrm{ng} / \mathrm{ml})$ & $141 \pm 25$ & $111 \pm 48$ \\
\hline time peak conc $\mathrm{c}_{(\mathrm{min})}$ & $58 \pm 33$ & $80 \pm 22$ \\
\hline
\end{tabular}

Values are expressed as mean \pm SD for six individual tests. (One volunteer did not participate in the blood sampling in the BHA-test. One set of data was deleted due to analytical problems.) Volunteers ingested 0.5 mg BHA/kg as a solution of $10 \%$ in com oil for ten days. Absorption of BHA is assumed to be complete. Differences are statistically not significant.

a: $A U C_{0-4 h}: A U C$ for $0-4$ hours following BHA intake.

b: plasma BHA peak concentration.

c: time of plasma BHA peak concentration. 


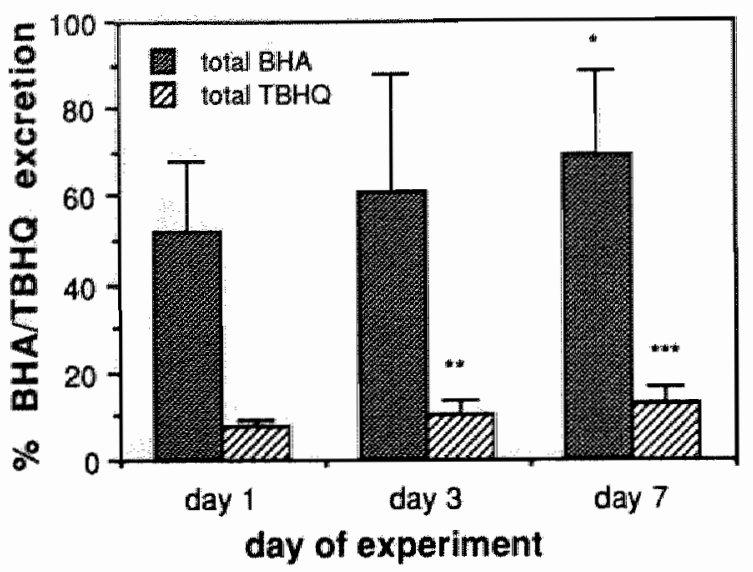

Figure 8-2: Excretion of total (un)conjugated BHA and TBHQ in urine samples collected for 24 hours following BHA administration. Recovery of metabolites is expressed as the percentage of the amount of BHA ingested on one day $(0.5 \mathrm{mg}$ BHA/kg body weight). On day 7 , only seven sets of data were used, since one volunteer reported to have nol collected his urine for several hours.

*: $P<0.05, * *: P<0.02, * * *: P<0.001$ vs day 1 .

TABLE 8-IV: CLINICAL BIOCHEMICAL PARAMETERS IN PLASMA FROM VOLUNTEERS BEFORE (DAYS -6 AND 0) AND DURING (DAYS 4 AND 7) BHA ADMINISTRATION.

\begin{tabular}{|c|c|c|c|c|}
\hline paramieteir & day -6 & day 0 & day 4 & day 7 \\
\hline L-aspartate-aminotransferase (U/1) & $9.0 \pm 3.9$ & $15.0 \pm 5.0$ & $15.4 \pm 6.6$ & $10.7 \pm 3.5$ \\
\hline Lualanin-aminotransferase $(\mathrm{U} /)$ & $10.0 \pm 2.8$ & $12.7 \pm 4.1$ & $12.8 \pm 3.8$ & $12.5 \pm 3.6$ \\
\hline L-gamma-glutamyltranspeptidase (U/1) & $8.3 \pm 2.2$ & $10.6 \pm 3.0$ & $11.2 \pm 3.6$ & $10.1 \pm 3.1$ \\
\hline lactate dehydrogenase $(U / 1)$ & $112 \pm 15$ & $178 \pm 34$ & $192 \pm 46$ & $123 \pm 18$ \\
\hline creatine phospho kinase (U/) & $117_{ \pm 191}$ & $52 \pm 19$ & $86 \pm 102$ & $81 \pm 84$ \\
\hline creatinine $(\mu \mathrm{M})$ & $107 \pm 17$ & $110 \pm 22$ & $107 \pm 13$ & $112 \pm 21$ \\
\hline total protein $(\mathrm{g} / \mathrm{l})$ & $69.9 \pm 3.4$ & $73.0 \pm 4.0$ & $72.3 \pm 4.3$ & $73.1 \pm 3.4$ \\
\hline albumin $(g /)$ & $39.9 \pm 1.3$ & $40.6 \pm 1.3$ & $40.5 \pm 1.2$ & $40.5 \pm 1.1$ \\
\hline urea (mM) & $3.5 \pm 1.5$ & $4.2 \pm 1.8$ & $3.9 \pm 1.2$ & $4.6 \pm 2.0$ \\
\hline $\mathrm{Na}^{+}(\mathrm{mEq} /)$ & $133 \pm 5^{\mathrm{a}}$ & $141 \pm 4$ & $143 \pm 4$ & $142 \pm 5$ \\
\hline $\mathrm{Cl} \cdot(\mathrm{mEq} / \mathrm{l})$ & $88 \pm 4^{a}$ & $93 \pm 2$ & $95 \pm 3$ & $94 \pm 2$ \\
\hline
\end{tabular}

Values are expressed as mean \pm SD for eight volunteers, who ingested $0.5 \mathrm{mg}$ BHA/kg from day 0 to day 9 . Differences are statistically not significant. a: for explanation see text. 


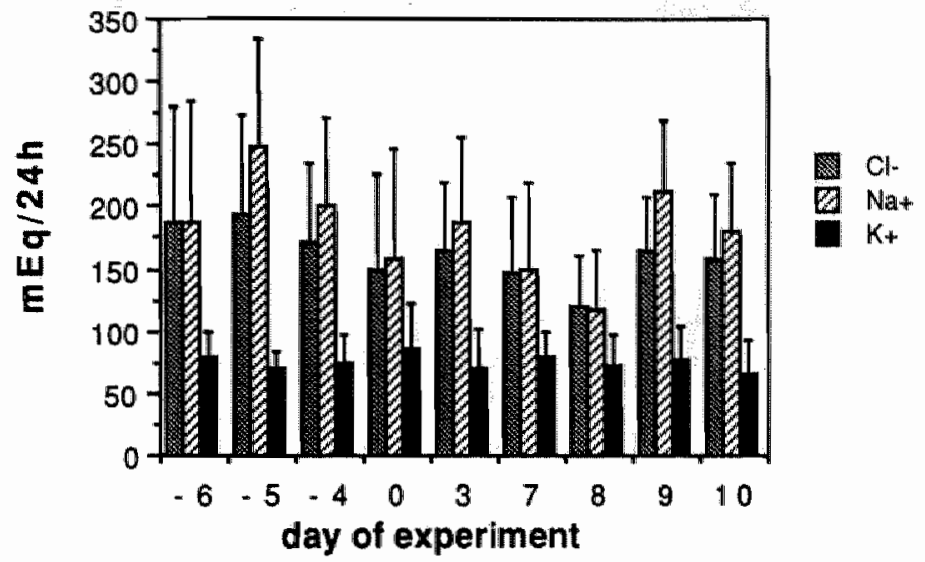

Figure 8-3: Excretion of electrolytes in urine on three days before and six days during oral BHA intake. Values are expressed as $m E q / 24$ h. No significant differences were found berween comparable days before (day $-6,-5$ and -4 ) and during (day 8, 9 and 10) BHA ingestion.

\section{Discussion}

Ten days of oral administration of the ADI for BHA to men is not expected to induce toxic effects. Since the ADI is derived from a NEL established in experiments with laboratory animals enforced by a safety factor, any significant biologically measurable effect of BHA in this particular study screening metabolic capacity as well as clinical diagnostic parameters should be considered as an adverse effect (31).

Both AP and PC are well established test substances for the assessment of phase-I and phase-II biotransformation capacity in man $(23,27-30,32,33)$. PC is mainly cleared from plasma by conjugation with glucuronic acid or sulphate, followed by excretion of the

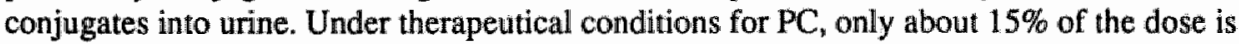
metabolized via other routes or excreted unmetabolized (23). Clearance of AP on the other hand is rate-limited by its metabolism via several cytochrome P-450 isozymes, followed by renal excretion of these metabolites, possibly as conjugates. For PC as well as AP the saliva/plasma concentration ratio is approximately 1 , which implies that blood sampling and concurrent discomfort for the participants can be avoided $(27,34)$.

As mentioned above, several different isozymes may take part in the biotransformation of xenobiotics, like AP, PC and BHA, as applied in the present test protocol. The biological fate of BHA has been evaluated in this study with respect to direct phase-II metabolism to sulphate and glucuronic acid conjugates as well as cytochrome $\mathrm{p}$-450-mediated oxidative demethylation into TBHQ (21). Next to the assessment of a possible self-induction of biotransformation of BHA, also an increase in total BHA-body burden due to accumulation of BHA or an excretion of metabolites over several days following administration could be assessed by this methodology. 
No significant differences in kinetic parameters or urinary metabolite profile were measured in either the PC or AP test, indicating that subacute oral intake of BHA at ADI-levels does not modulate phase-I metabolic capacity in man as measurable with AP as test-substance nor that it alters phase-II (1.c. glucuronidation and sulphatation) biotransformation capacity in man as measurable with $\mathrm{PC}$ as test-substance. Kinetic parameters and urinary metabolite profiles of $\mathrm{AP}$ and $\mathrm{PC}$ are in agreement with literature data $(23,27-30,32,33)$. Also, plasma BHA kinetics and urinary excretion of BHA and TBHQ (conjugates) on day 0 are not different from our previous reported values (21). With respect to metabolism of BHA in man, however, significantly higher amounts of (un)conjugated BHA and TBHQ were detected in urine in the later period of the experiment. This may indeed reflect a biological effect of BHA in man, either arising from an induction of phase-I as well as phase-II BHAspecific biotransformation enzymes or from an inhibition of other unknown pathways of BHA metabolism. However, the lack of any change in the ratio of BHA/TBHQ would suggest that alterations in the metabolism of BHA are less likely than bioaccumulation On the other hand, an increase in urinary excretion of (un)conjugated BHA and TBHQ could also result from bioaccumulation of BHA and/or its metabolites in peripheral compartments. However, no BHA could be detected in plasma samples obtained on day 7 prior to BHA intake $(t=0)$, thereby not indicating an accumulation of BHA per se in the body. As concerns metabolites of $\mathrm{BHA}$, in a previous experiment we showed that only about $50 \%$ of a single oral dose of BHA was recovered from urine and feces on days 1 to 4 post administration; metabolites of BHA were mainly (about $46 \%$ ) excreted on day 1 but also on days $2-4$, although to a minor extent (21). In the same study, due to a thigh detection limit, TBHQ could only be detected in urine collected on the first day of administration (21). Although BHA apparently follows first order kinetics in man (21), the possible contribution of peripheral compartments for BHA bioaccumulation cannot be monitored due to the analytical inability of measuring very low plasma BHA levels. The hypothesis of an involvement of deeper compartments in the kinetics of BHA in man may be confirmed by the fact that despite the increase in urinary levels of metabolites, there is no difference in the TBHQ/BHA ratio.

Increases in urinary levels of (un)conjugated BHA and TBHQ may alternatively be explained by a slow clearance of BHA- and TBHQ-conjugates from the body, resulting in an excretion over several days following BHA administration, as shown before for BHA (21), which also leads to a daily gradual increase in levels of conjugates in urine. Unfortunately , there are no data on plasma $t 1 / 2$ 's of BHA- and TBHQ-conjugates in man or animal.

Preliminary data from a subacute experiment using male Wistar rats, fed $2 \%$ BHA in the diet for two weeks, also indicate a gradual increase in urinary excretion of (un)conjugated BHA and TBHQ.

Further research is needed in order to determine whether increased levells of (un)conjugated BHA and TBHQ in urine result from an alteration in BHA-specific phase-I and -II biotransformation pathways, which should be regarded as a "biological effect" (31) and consequently as an adverse effect of BHA, or from a still unknown kinetic behaviour of BHA in man.

Generally, BHA is considered a component of low toxicity. The NEL used for the assessment of an ADI for man, is $62.5 \mathrm{mg} / \mathrm{kg}$ bodyweight in rodents (20). Oral administration of higher amounts of BHA, up to $500 \mathrm{mg} / \mathrm{kg}$ body weight, to other species (dogs, pigs, monkeys) also did not reveal severe toxicity of BHA, although some differences in biochemical or haematological blood parameters as well as urinary electrolyte 
excretion have been reported $(35-37)$.

The results of the present report show that consumption of BHA at the ADI level by man does not cause any hepatic or renal damage, as would be indicated by changes in the parameters measured in this study. Clinical plasma and urine parameters are in close agreement with reference data (38).

Despite the apparent absence of effects of subacute administration of $0.5 \mathrm{mg} \mathrm{BHA} / \mathrm{kg}$ to man on liver and kidney function, it should be noted that BHA acts as a complete carcinogen in the forestomach of rodents and that also other parts of rodent gastro-intestinal tract (oesophagus, glandular stomach, small intestines, colon/rectum) are susceptible to the proliferation enhancing effects of BHA (39). Moreover, also in non-rodents (monkeys, pigs) BHA induces proliferative changes in the oesophagus $(36,37)$. Since BHA does not appear to possess mutagenic potential (40), further research is necessary to deternine the mechanism of its carcinogenicity, in relation to its possible potential of modulating its own biotransformation.

\section{Acknowledgements}

The authors deeply appreciate the contributions made to this study by mr. W. Saris, mr. G. van Kranenburg, mr. E. Beckers, mrs. D. van Dale and all volunteers.

\section{References}

1 R.J. Sims and J.A. Fioriti, Antioxidants as stabilizers for fats, oils, and lipid-containing foods. In" CRC Handbook of food additives, Vol. II, (1980) edited by T.E. Furia, 2nd Ed. pp. 13-56. Chemical Rubber Company, Boca Raton, FL.

2 Anonymous, Butylated hydroxyanisole (BHA). IARC Monographs 40 (1986) 123.

3 N. Ito, S. Fulkushima ,A. Hagiwara, M. Shibata and T. Ogiso, Carcinogenicity of butylated hydroxyanisole in F344 rats. J. Natl. Cancer Inst. 70 (1983) 343

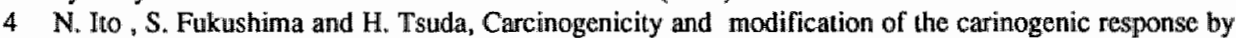
BHA, BHT and other antioxidants. C.R.C., Crit.Rev.Toxicol. 15 (1985) 109.

5 T. Masui, M. Hirose, K. Imaida, S. Fukushima, S. Tamano and N. Ito, Sequential changes of the forestomach of F344 rats, Syrian golden hamsters, and B6C3F, mice treated with butylated hydroxyanisole. Gann 77 (1986) 1083.

6 R. Abraham, K.F. Benitz, G. Patil and R. Lyon, Rapid induction of forestomach tumors in partially hepatectomized Wistar rats given butylated hydroxyanisole. Exp. Mol. Pathol, 44 (1986) 14.

7 N. Ito , S. Fukushima, S. Tamano, M. Hirose and A. Hagiwara, Dose response in butylated hydroxyanisolle induction of forestomach carcinogenesis in F344 rats. I. Natl. Cancer Inst. 77 (1986) 1261.

8 D.B. Clayson, F. Iverson, E. Nera, E. Lok , C. Rogers „C. Rodrigues , D. Page and K. Karpinski, Histopathological and autoradiographical studies on the forestomach of F344 rats treated with butylated hydroxyanisole and related chemicals. Food Chem. Toxicol. 24 (1986) 1171.

9 H. Verhagen, B. Schotte, M.M.J. Reynders, G.H. Blijham, F. ten Hoor and J.C.S. Kleinjans," Efrect of short-term dietary administration of butylated hydroxyanisole on cell kinetjc paramelers in ral gastrointestinal tract, assessed by immunocytochemistry and flow-cytometry. Carcinogenesis. 9 (1988) 1107.

10 L.W. Wattenberg, Inhibitors of chemical carcinogens. I. Environ. Pathol. Toxicol. 3 (1980) 35.

11 L.W. Wattenberg, Chemoprevention of cancer. Cancer Res. 45 (1985) 1.

12 G. Hocman, Chemoprevention of cancer: phenolic antioxidants (BHT, BHA). Int. J. Biochem. 20 (1988) 639.

13 R. Kahl, Synthetic antioxidants: biochemical actions and interference with radiation, toxic compounds, chemical mutagens and chemical carcinogens. Toxicology 33 (1984) 185. 
14 R. Kahl, The dual role of antioxidants in the modification of chemical carcinogenesis. J. Enwiron. Sci. Health 4(1) (1986) 47.

15 Anonymous, Final Report of the safety assessment for BHA. J. Am. Coll. Toxicol. 3 (1984) 83.

16 R. Pastorelli, A. Ancideli, R. Fanelli and L. Airoldi, Effect of acute and chronic butylated hydroxyanisole administration on in wivo glucuronidation of $\mathrm{N}$-nitrosobutyl(4-hydroxybutyl)amine in rats. Food Chem. Toxicol. 26 (1988) 419.

17 Z. Gregus and C.D. Klaassen, Effect of butylated hydroxyanisole on hepatic glucuronidation and biliary excretion of drugs in mice. J. Pharm. Pharmacol. 40 (1988) 237.

18 S. Garatini, Toxic effects of chemicals: difficulties in extrapolating data from animals to man. C.R.C. Crit. Rev. Toxicol. 16 (1986) 1.

19 A. Whittemore, S.C. Grosscr and A. Silvers, Pharmacokinetics in low dose extrapolation using animal cancer data; Fundam. Appl. Toxicol. 7 (1986) 183.

20 Joint FAO/WHO Expert Committee on Food Additives, Toxicological evaluation of some food additives and contaminants. Butylated hydroxyanisole (BHA). WHO Food. Add. Ser. 21 (1986) 3.

21 H. Verhagen, H.H.W. Thijssen, F. ten Hoor and J.C.S. Kleinjans, Disposition of single oral doses of britylated hydroxyanisole in man and rat. Food Chem. Toxicol. 27 (1989) 151.

22 H. Verhagen, H.H.W. Thijssen and J.C.S. Kleinjans, Sensitive high- performance liquid chromatographic method for the routine determination of butylated hydroxyanisole in plasma. $J$. Chromatogr. 413 (1987) 282.

23 J.O. Miners, J. Altwood and D.J. Birkett, Influence of sex and oral contraceptive steroids on paracetamol metabolism. Brit. J. Clin. Pharmacol. 16 (1983) 503.

24 J. Miners. J.F. Adams and DJ. Birkett, A simple HPLC assay for urinary paracetamol metabolites and its use to characterize the $\mathrm{C} 3 \mathrm{H}$ mouse as a model for paracetamol metabolism studies. Clin. Exp. Pharmacol. Physioll. 11 (1984) 209.

25 T.M. Campbell, E.W. Murdaugh and P.G. Killenberg, Determination of antipyrine in plasma by reversed-phase high-performance liquid chromatography. J. Chromatogr. 163 (1979) 236.

26 M.W.E. Teunissen, J.E. Meerburg-van der Torren, N.P.E. Vermeulen and D.D. Breimer, Automated high-performance liquid chromatographic determination of antipyrine and its main metabolites in plasma, saliva and urine, including 4,4'-dihydroxy-antipyrine. J. Chromatogr. 278 (1983) 367.

27 F. Kamali, J.R. Fry and G.D. Bell, Salivary excretion of paracetamol in man. J. Pharm. Pharmacol. 39 (1.987) 150 .

28 M. Danhof and D.D. Breimer, Studies on the different metabolic pathways of antipyrine in man.

1. Oral adrministration of 250,500 and $1000 \mathrm{mg}$ to healthy volunteers. Br. J. Clin. Pharmacol. 8 (1979) 529.

29 M. Døssing, S. Loft, J. Sonne and E. Schroeder, Antipyrine and metronidazole metabolism during occupational exposure to gasoline. Int. Arch. Occup. Environ. Health 60 (1988) 115.

30 J. Póner, M. Danhof, M.W.E. Teunissen, D.D. Breimer and P.D. Whiteman, The disposition of antipyrine and its metabolites in young and elderly healthy volunteers. Br. J. Clin. Pharmac. 24 (1987) 51.

31 R. L. Zielhuis and P. Th. Henderson, Definitions of monitoring activities and their relevance for the practice of occupational health. Int. Arch. Occup. Enwiron. Health 57 (1986) 249.

32 E.S. Vessell, The antipyrine test in clinical pharmacology: conceptions and misconceptions. Clin. Pharmacol Ther. $26(1979) 275$.

33 J.O. Miners, J. Attwood and D.J. Birketu, Determinants of acetaminophen metabolism: effect of inducers and inhibitors of drug metabolism on acetaminophen's metabolic pathways. Clin. Pharmacol. Ther. 35 (1984) 480.

34 M. Danhof and D.D. Breimer, Therapeutic drug monitoring in saliva. Clin. Pharmacakin. 3 (1978) 39.

35 M. Tobe, 'T. Furuya, Y. Kawasaki, K. Naito , K. Sekita, K. Matsumoto, T. Ochiai, A. Usui, T. Kokubo. J. Kanno and Y. Hayashi, Six-month toxicity study of butylated hydroxyanisole in beagle dogs̀. Food Chem. Toxicol. 24 (1986) 1223.

36 G. Würtzen and P. Olsen, BHA study in pigs. Food Chem. Toxicol. 24 (1986) 1229.

37 F. Iverson "J. Truelove, E. Nera, J. Wong, E. Lok and D.B. Clayson, An 85-day study of butylated hydroxyanisole in the cynomolgus monkey. Cancer Lett. 26 (1985) 43.

38 L.A. Kaplan and A.J. Pesce, Clinical chemistry. Theory, analysis, and correlation. The C.V. Mosby Company, St. Louis (1984). 
39 C. Furnée, H. Verhagen, B. Schutte, M.M.J. Reynders, G.H. Blijham, F. ten Hoor and J.C.S. Kleinjans, $A$ short-term dose-response study on the effects of butylated hydroxyanisolle on cell kinetic parameters in the gastro-intestinal tract of male wistar rats. Pharmac. Weekbl. Sci. Ed. 11 (1989) B6.

40 G.J. Hageman, H. Verhagen and J.C.S. Kleinjans, Butylated hydroxyanisole, butylated hydroxytolluene and tert-butylhydroquinone are not mutagenic in the Salmonella/microsome assay using new tester strains. Mut. Res. 208 (1988) 207. 

PART IV

STUDIES ON THE MECHANISM OF

CARCINOGENICITY OF BHA AND BHT 



\title{
Chapter 9
}

\begin{abstract}
Butylated hydroxyanisole, butylated hydroxytoluene and tert-butylhydroquinone are not mutagenic in the Salmonella/microsome assay using new tester strains
\end{abstract}

\author{
Geja J. Hageman, Hans Verhagen and Jos C.S. Kleinjans \\ Mutation Research 208 (1988) 207-211
}

\begin{abstract}
The phenolic antioxidants butylated hydroxyanisole (BHA), butylated hydroxytoluene (BHT) and tert-butylhydroquinone (TBHQ) were reassessed for mutagenic activity using recently developed Salmonella tester strains TA97, TA102 and TA104, and in addition TA100. None of the phenolic antioxidants showed mutagenic activity, either with or without metabolic activation. At doses of $100 \mu \mathrm{g} / \mathrm{plate}$ and higher all 3 phenolic antioxidants exhibited toxic effects. A modification of the assay using the preincubation procedure with strain TA104 did not affect mutation frequencies. Combinations of BHA and BHT, tested to detect possible synergistic effects, did not exert mutagenic activity.
\end{abstract}

\section{Introduction}

The phenolic antioxidants butylated hydroxyanisole (BHA), butylated hydroxytoluene (BHT), and tert-butylhydroquinone (TBHQ) are frequently used in fat- and oil-containing foods to retard rancidity and increase shelf life. BHA and BHT are permitted in most Western countries, but addition of TBHQ, which is currently used in the USA, is generally not allowed in Europe. Recently new acceptable daily intakes (ADI's) were established for BHA, BHT and TBHQ by the FAO/WHO (JECFA, 1986). These ADI's, however, are temporary and further toxicological studies are recommended.

As has been extensively reviewed by Kahl (1984) "much attention has been paid to antitumorigenic and antimutagenic actions of phenolic antioxidants and relatively little to possible adverse biological effects. In the Salmonella/microsome assay, BHA, BHT and TBHQ have repeatedly been found to be non-mutagenic, and inhibition of mutagenic activity of known genotoxins like 3,2'-dimethyl-4-aminobiphenyl and benzo[a]pyrene by BHA as well as by BHT has been reported (Ishidate et al., 1984; Reddy et al., 1983; Calle and Sullivan, 1982; Bonin and Baker, 1980).

Some mutagenic potential however, cannot be excluded for phenolic antioxidants, because in a number of other short-term mutagenicity assays, BHA, BHT and TBHQ did show genotoxic activity (Sheu et al., 1986; Bruce and Heddle, 1979; Ishizaki et al., 1979; Abe and Sasaki, 1977). Kawachi et al. (1980) reported positive results for BHA and BHT in the 
Bacillus subtilis rec. assay indicating DNA-damaging effects. In addition, BHA and BHT were found to enhance mutagenicity of aflatoxin BI in the Salmonella/microsome assay (Shelef and Chin, 1980) and more recently, even tumor-inducing and tumor-promoting actions of BHA and BHT have been described (Imaida et al., 1983; Ito et al., 1985).

In the present study, therefore, the mutagenic activity of BHA, BHT and TBHQ in the Salmonella/microsome assay was re-evaluated using recently developed Salmonella tester strains. The set of tester strains employed consisted of TA100, which is reverted by basepair substitutions at the G.C. base pairs, and strain TA97, which detects frame-shift mutations and is reported to be more sensitive than strain TA1537 which it replaces (Maron and Ames, 1983). Strains TA102 and TA104, developed to test oxidative mutagens that are not detected efficiently by other tester strains (Marnett et al., 1985; Levin et al., 1982), were also used. These latter strains differ from other standard tester strains in that these are reverted by base-pair substitution at the A-T base pairs (Marnett et al., 1985).

The combination of BHA and BHT, which is likely to occur in the European daily food consumption pattern, was also tested to detect possible synergistic effects.

\section{Experimental}

Food grade BHA and BHT were a gift from Jam Dekker Company, Wormerveer (The Netherlands). TBHQ was purchased from Aldrich, Brussels (Belgium). All other chemicals were of the highest grade commercially available. Salmonella typhimurium tester strains were kindly provided by Professor Bruce N. Ames, University of Berkely, CA (USA). The strains were checked routinely for ampicillin and tetracyclin resistance, crystal-violet and ultraviolet light sensitivity, and spontaneous revertants.

Rat liver S9 fractions were prepared from Aroclor-treated rats as described by Maron and Ames (1983). The Salmonella/microsome assay was conducted according to standard protocols (Maron and Ames, 1983). New tester strains TA97, TA102 and TA104 were used, to which strain TA100 was added for comparison with previously published findings. The phenolic antioxidants were tested in triplicate at doses of $1,10,50,100$. 200,500 and $1000 \mu \mathrm{g} /$ plate, dissolved in $0.1 \mathrm{ml}$ dimethylsulphoxide (DMSO). Liver S9 fraction was added at a concentration of $20 \mu \mathrm{l} /$ plate. Amounts of $100 \mu \mathrm{g}$ of phenolic antioxidant per plate were also tested with a $50 \mu \mathrm{l} /$ plate concentration of $S 9$ fraction.

Because BHA and other phenolic antioxidants have antimicrobial properties (Chang and Branen, 1975) a nontoxic dose range was established. Toxicity of the phenolic antioxidants was determined by plating each concentration in triplicate with $0.1 \mathrm{ml}$ of a diluted culture $\left(10^{6}\right.$ times) and top agar enriched with $10 \mu$ mole of L-histidin and $0.05 \mu$ mole of D-biotin.

Positive controls were included in every experiment to check activity of the $\mathrm{S} 9 \mathrm{mix}$ and the mutability of the strains. Test agents and doses were as follows: without $59 \mathrm{mix}$ for strain TA97 $10.0 \mu \mathrm{g}$ 4-nitro-ophenylenediamine/plate; for TA100 $1.0 \mu \mathrm{g}$ sodium axide/plate; for TAlO2 $50.0 \mu \mathrm{g}$ sertbutylhydroperoxide/plate and for TA104 36.0 $\mathrm{\mu g}$ of methylglyoxal/plate. With S9 mix for strains TA97 and

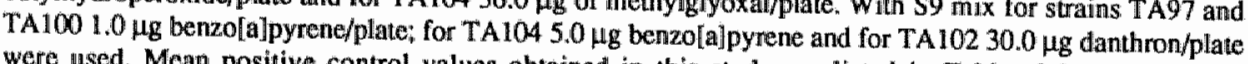
were used. Mean positive control values obtained in this study are listed in Tables 9-1 and 9-11. The combination of BHA and BHT was tested in three ratios at a total amount of $50 \mu \mathrm{g} / \mathrm{plate}_{\text {w }}$ which dose showed no toxic interference with mutagenicity testing. 


\section{Results and discussion}

Survival studies performed in absence of $\$ 9$ mix showed that BHA and TBHQ were highly toxic to all tester strains at doses of 500 and $1000 \mu \mathrm{g} / \mathrm{plate}$ with none or a small percentage of the bacteria surviving. BHT tended to be less toxic, since at a dose of $1000 \mu \mathrm{g} / \mathrm{plate}$ still 30 to $50 \%$ survival was observed. At a $100-\mu \mathrm{g} / \mathrm{plate}$ dose, however, the percentage of surviving bacteria started to decline, varying from 35 to $80 \%$ for the different strains. The combination of BHA and BHT, tested at a total amount of $50 \mu \mathrm{g} / \mathrm{plate}$, appeared to be slightly toxic, but remained within acceptable limits $(35-100 \%)$. Comparison of the results with and without $S 9$ mix reported in Table $9-I$ indicates a reduction of toxicity in the presence of $\mathrm{S} 9 \mathrm{mix}$.

Within the non-toxic dose range reversion frequencies of all tester strains showed no significant increase for $\mathrm{BHA}, \mathrm{BHT}$ and $\mathrm{TBHQ}$, both with and without metabolic activation (Table 9-I). Although testing of BHT in strains TA102 and TA.104 showed a tendency toward increased numbers of revertants no significant dose-response relationship was found for BHT. At concentrations of $100 \mu \mathrm{g} /$ plate the addition of more concentrated $\$ 9 \mathrm{mix}$ did not affect reversion frequencies when compared to the usual concentration of $\$ 9$ mix (results not shown).

During in vitro microsomal metabolism BHA is converted to TBHQ and tert-butylquinone (Cummings et al., 1985; Rahimtula, 1983); oxidation products of BHA include formaldehyde which is a direct-acting mutagen to strain TA104 (Marnett et al., 1985). This strain and TA102 are also sensitive for metabolically activated products of various quinones (Chesis et al., 1984; Levin et al., 1982), in which cases mutagenicity has been suggested to be attributable to the generation of oxygen-free radicals. However, neither BHA, nor its metabolites, nor TBHQ showed mutagenic activity under the conditions used in this study. When added to rat liver microsomal suspensions, BHA and BHT have been found to stimulate NADPH-oxidase activity in a dose-dependent manner resulting in a 2- to 3-fold increased production of hydrogen peroxide (Kahl and Hildebrandt, 1986). Maximal stimulation of hydrogen peroxide formation has been observed at concentrations ranging from 10 to $100 \mu \mathrm{g} / \mathrm{ml}$ for both BHA and BHT. Hydrogen peroxide is among oxidative mutagens detected by strains TA102 and TA104 (Levin et al, 1982). Although BHA and BHT were tested at the dose range at which maximal hydrogen peroxide production is to be expected, our results indicate that the amount of hydrogen peroxide formed during oxidative metabolism of BHA and BHT in the Ames assay probably was not sufficient to induce mutagenicity. Moreover, deactivation by free radical detoxifying enzyme activities or by glutathione present in rat liver $S 9$ mix might have occurred. Therefore additional testing of BHA using strains TA100 and TA104 in the presence of rat liver microsomes from Aroclor induced rats was performed, but no increased reversion frequencies were observed either (results not shown).

The preincubation procedure, a modification of the Ames assay that provides a more sensitive assessment of mutagenic activity, was used to re-evaluate mutagenicity results found with strain TA104. Table 9-II shows that none of the phenolic antioxidants was mutagenic in strain TA104. 
TABLE 9-1: MUTAGENICITY OF BHA, BHT, TBHQ AND COMBINATIONS OF BHA AND BHT IN THE SALMONELLA/MICROSOME ASSAY.

Compound Dose
(ugplate)

\begin{tabular}{|c|c|c|c|c|c|c|c|c|c|}
\hline & & \multicolumn{2}{|l|}{ TA97 } & \multicolumn{2}{|l|}{ TAlOO } & \multicolumn{2}{|l|}{ TA 102} & \multicolumn{2}{|l|}{ TA104 } \\
\hline & & $\$ 2$ & \pm 59 & -52 & $+\$ 2$ & $-\$ 9$ & $+\$ 9$ & -59 & $+\$ 9$ \\
\hline \multirow[t]{6}{*}{$\mathrm{BHA}$} & 1 & $121 \pm 3$ & $147 \pm 9$ & $83 \pm 4$ & $85 \pm 8$ & $243 \pm 13$ & $363 \pm 57$ & $333 \pm 5$ & $361 \pm 91$ \\
\hline & 10 & $117 \pm 2$ & $146 \pm 6$ & $76 \pm 12$ & $81 \pm 14$ & $224+24$ & $387 \pm 2$ & $371 \pm 27$ & $409 \pm 50$ \\
\hline & 100 & $109 \pm 12$ & $138 \pm 18$ & $92 \pm 11$ & $97 \pm 12$ & $197 \pm 38$ & $277 \pm 16$ & $329 \pm 16$ & $391 \pm 47$ \\
\hline & 200 & $136 \pm 9$ & $174 \pm 19$ & $102 \pm 8$ & $76 \pm 12$ & $171 \pm 11$ & $381 \pm 9$ & $328 \pm 11$ & $472 \pm 54$ \\
\hline & 500 & $106 \pm 13$ & $144 \pm 12$ & $54 \pm 9$ & $90 \pm 10$ & $18 \pm 9^{a}$ & $112 \pm 8$ & $367 \pm 29$ & $392 \pm 68^{a}$ \\
\hline & 1000 & $0^{a}$ & $0^{a}$ & $0^{\mathrm{a}}$ & $0^{a}$ & $15 \pm 1^{a}$ & $182 \pm 67 a$ & $0^{a}$ & $17 \pm 10^{\mathrm{a}}$ \\
\hline \multirow[t]{6}{*}{$\mathrm{BHT}$} & 1 & $114 \pm 19$ & $138 \pm 10$ & $72 \pm 10$ & $84 \pm 34$ & $298 \pm 48$ & $393+33$ & $508 \pm 44$ & $513 \pm 72$ \\
\hline & 10 & $114 \pm 9$ & $132 \pm 17$ & $73 \pm 10$ & $77 \pm 8$ & $271 \pm 1$ & $347 \pm 21$ & $530 \pm 83$ & $522 \pm 67$ \\
\hline & 100 & $104 \pm 3$ & $96 \pm 12$ & $67 \pm 9$ & $70 \pm 5$ & $294 \pm 29$ & $353 \pm 41$ & $542+80$ & $583+34$ \\
\hline & 200 & $136 \pm 4$ & $176 \pm 15$ & $71 \pm 23$ & $69 \pm 11$ & $265 \pm 18$ & $381 \pm 64$ & $486 \pm 49$ & $463 \pm 23$ \\
\hline & 500 & $140 \pm 10$ & $163 \pm 29$ & $47 \pm 31$ & $80 \pm 4$ & $255 \pm 40$ & $411 \pm 25$ & $464 \pm 74$ & $489 \pm 24$ \\
\hline & 1000 & $124 \pm 17$ & $132 \pm 31$ & $72 \pm 6$ & $87 \pm 9$ & $268 \pm 15$ & $374 \pm 42$ & $498 \pm 89$ & $450 \pm 48$ \\
\hline \multirow[t]{6}{*}{ TBHQ } & 1 & $117 \pm 17$ & $143 \pm 16$ & $69 \pm 11$ & $88 \pm 10$ & $222 \pm 26$ & $317 \pm 14$ & $476 \pm 143$ & $510 \pm 21$ \\
\hline & 10 & $105 \pm 15$ & $145 \pm 11$ & $59 \pm 8$ & $86 \pm 4$ & $231 \pm 2$ & $317 \pm 13$ & $463 \pm 20$ & $535 \pm 39$ \\
\hline & 100 & $129 \pm 18$ & $136 \pm 3$ & $65 \pm 5$ & $65 \pm 14$ & $198 \pm 34$ & $287 \pm 20$ & $413 \pm 5$ & $505 \pm 34$ \\
\hline & 200 & $161 \pm 37$ & $188 \pm 10$ & $79 \pm 6$ & $86 \pm 7$ & $151 \pm 12^{a}$ & $387 \pm 23$ & $307 \pm 29$ & $347 \pm 3$ \\
\hline & 500 & $150 \pm 34$ & $171 \pm 13$ & $0^{\mathrm{a}}$ & $81 \pm 3$ & $97 \pm 17^{\mathrm{a}}$ & $297 \pm 36$ & $315 \pm 54$ & $319 \pm 21$ \\
\hline & 1000 & $32 \pm 18^{a}$ & $142 \pm 27$ & $0^{\mathrm{a}}$ & $64 \pm 7$ & $0^{\mathrm{a}}$ & $147 \pm 11^{\mathrm{a}}$ & $31 \pm 23^{a}$ & $208 \pm 12^{\mathrm{a}}$ \\
\hline \multirow[t]{5}{*}{ BHA/BHT } & $50 / 0$ & $1.16 \pm 8$ & $162 \pm 31$ & $109 \pm 6$ & $109 \pm 12$ & $198 \pm 16$ & $271 \pm 36$ & $525 \pm 69$ & $444 \pm 35$ \\
\hline & $33 / 17$ & $142 \pm 8$ & $168 \pm 17$ & $81 \pm 12$ & $84 \pm 14$ & $194 \pm 24$ & $313 \pm 62$ & $618 \pm 55$ & $492 \pm 43$ \\
\hline & $25 / 25$ & $135 \pm 13$ & $157 \pm 15$ & $80 \pm 10$ & $82 \pm 17$ & $221 \pm 22$ & $309 \pm 45$ & $624 \pm 57$ & $502 \pm 158$ \\
\hline & $17 / 33$ & $137 \pm 4$ & $151 \pm 13$ & $78 \pm 5$ & $80 \pm 13$ & $214 \pm 23$ & $310 \pm 45$ & $591 \pm 71$ & $462 \pm 3$ \\
\hline & $0 / 50$ & $143 \pm 7$ & $164 \pm 2$ & $72 \pm 7$ & $82 \pm 14$ & $222+24$ & $385 \pm 23$ & $472 \pm 27$ & $464 \pm 31$ \\
\hline \multicolumn{2}{|c|}{ posilive control } & $743 \pm 55$ & $320 \pm 16$ & $461 \pm 30$ & $517 \pm 79$ & $1900 \pm 190$ & $979 \pm 99$ & $>2000$ & $1213 \pm 153$ \\
\hline
\end{tabular}

For BHA, BHT, TBHQ and combinations of BHA and BHT values are given as mean \pm SD for 3 plates from one representative experiment. Mean numbers of spontaneous revertants are 130,152, 84, 223, 331, 430 and 468 for strains TA97-S9, TA97+S9, TA100-S9, TA100+\$9, TA102-S9, TA102+S9, TA104-S9 and TA104+S9, respectively. For positive controls values are given as mean $\pm S D$ for at least 6 plates from 2 individual experiments.

a: Growth inhibition due to toxic effects. 
TABLE 9-II: MUTAGENICITY OF BHA, BHT, TBHQ AND COMBINATIONS OF BHA AND BHT IN THE SALMONELLA/MICROSOME ASSAY WTTH STRAIN TA104 USING THE LIQUID PREINCUBATION PROCEDURE (20 min at $37^{\circ} \mathrm{C}$ ).

\begin{tabular}{|c|c|c|c|}
\hline \multirow[t]{2}{*}{ Compound } & \multirow{2}{*}{$\begin{array}{r}\text { Dose } \\
(\mu g / \text { plate })\end{array}$} & \multicolumn{2}{|c|}{ Number of hist nevertants per plate } \\
\hline & & TA104-59 & TA104 +\$9 \\
\hline \multirow[t]{6}{*}{$\mathrm{BHA}$} & 1 & $393 \pm 39$ & $473 \pm 44$ \\
\hline & 10 & $381 \pm 48$ & $463 \pm 58$ \\
\hline & 100 & $255 \pm 23$ & $389 \pm 74$ \\
\hline & 200 & $340 \pm 54$ & $430 \pm 31$ \\
\hline & 500 & $75 \pm 129^{a}$ & $156 \pm 144$ i \\
\hline & 1000 & $\because 0^{\mathrm{a}}$ & $0^{2}$ \\
\hline \multirow[t]{6}{*}{$\mathrm{BHT}$} & 1 & $459 \pm 30$ & $500 \pm 76$ \\
\hline & 10 & $490 \pm 104$ & $519 \pm 62$ \\
\hline & 100 & $542 \pm 65$ & $551 \pm 38$ \\
\hline & 200 & $366 \pm 75$ & $569 \pm 51$ \\
\hline & 500 & $409 \pm 10$ & $473 \pm 13$ \\
\hline & 1000 & $393 \pm 83$ & $515 \pm 74$ \\
\hline \multirow[t]{6}{*}{ TBHQ } & 1 & $422 \pm 199$ & $445 \pm 18$ \\
\hline & 10 & $331 \pm 67^{a}$ & $448 \pm 66$ \\
\hline & 100 & $0^{\mathrm{a}}$ & $530 \pm 122$ \\
\hline & 200 & $18 \pm 11^{\mathrm{a}}$ & $550 \pm 74$ \\
\hline & 500 & $17 \pm 17^{\mathrm{a}}$ & $213 \pm 20^{\mathrm{a}}$ \\
\hline & 1000 & $0^{\mathrm{a}}:$ & $13 \pm 8^{a}$ \\
\hline \multirow[t]{5}{*}{ BHA/BHT } & $50 / 0$ & $512 \pm 62$ & $518 \pm 99$ \\
\hline & $33 / 17$ & $417 \pm 27$ & $499 \pm 58$ \\
\hline & $25 / 25$ & $378 \pm 51$ & $584 \pm 94$ \\
\hline & $17 / 33$ & $543 \pm 59$ & $491 \pm 37$ \\
\hline & $0 / 50$ & $458 \pm 67$ & $437 \pm 36$ \\
\hline positive control & & $>2000$ & $1195 \pm 88$ \\
\hline
\end{tabular}

For BHA, BHT, TBHQ and combinations of BHA and BHT, values are given as mean \pm SD for 3 plates. Mean numbers of spontaneous revertants are 441 and 533 for TA104-S9 and TA104 +\$9, respectively. For positive controls values are given as mean \pm SD for at least 6 plates from 2 individual experiments.

a: Growth inhibition due to toxic effects. 
The increased number of revertants observed for BHT in this strain without preincubation therefore is likely to have been accidental. Also the combination of BHA and BHT showed no mutagenic properties, all though a slight but insignificant increase in reversion frequencies was found in strain TA104 without metabolic activation (Table 9-I). Application of the preincubation procedure, however, did not result in increased reversion frequencies (Table 9.II), thus giving no clear indication of synergistic effects of BHA/BHT.

As phenolic antioxidlants reveal mutagenic potential in several micro-organisms applying mutagenicity tests other than the Ames assay (Kawachi et al., 1980; Ishizaki et al, 1979) and have been found to induce chromosome aberrations in mammalian cells (Bruce and Heddle, 1979; Abe and Sasaki, 1977), it is evident from the results obtained in this study that the Salmonella/microsome assay is not able to provide conditions for the detection of mutagenic activity of BHA, BHT and TBHQ.

\section{References}

- Abe, S. and M. Sasaki (1977) Chromosome aberrations and sister chromatid exchanges in Chinese hamster cells exposed to various chemicals, J. Natl. Cancer Inst., 58, 1635-1640.

- Bonin, A.M. and R.S.U. Baker (1980) Mutagenicity testing of some approved food additives with the Salmonella/microsome assay, Fd. Technol. Austr., 32, 608-611.

- Bruce, W.R. and J.A. Heddle (1979) The mutagenic activity of 61 agents as determined by the micronucleus, Salmonella and sperm abnormality test, Can. J. Genet. Cytol., 21, 319-334.

- Calle, L.M. and P.D. Sullivan (1982) Screening antioxidants and other compounds for antimutagenic properties towards benzo(a)pyrene-induced mutagenicity in strain TA98 of Salmonella typhimurium, Mutation Res., 101, 99-114.

- Chang, H.C. and A.L. Branen (1975) Antimicrobial effects of butylated hydrox yanisole (BHA), J. Fd. Sci., 40, 349-351.

- Chesis, P.L., D.E. Levin, M.T. Smith, L. Emster and B.N. Ames (1984) Mutagenicity of quinones: Pathways of metabollic activation and detoxification, Proc. Natl. Acad. Sci. USA, 81, 1696-1700.

- Cummings, S.W., Ansari, G.A.S., Crouch, L.S. and R.A. Prouch (1985) Metabolism of 3-tert-butyl4-hydroxyanisole by microsomal fractions and isolated hepatocytes, Cancer Res., 45, 5617-5624.

- Imaida, K., S. Fukushima, T. Shirai, M. Ohtari, K. Nakanishi and N. Ito (1983) Promoting activities

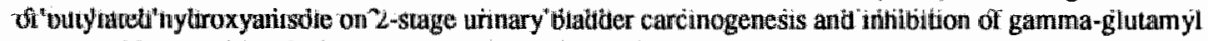
transpeptidase positive foci development in the liver of rats, Carcinogenesis, 4, 895-899.

- Ishidate, M., T. Sofuni, K. Yoshikawa, M. Hayashi, T. Nohmi, M. Sawada and A. Matsuoka (1984) Primary mutagenicity screening of food additives currently used in Japan, Fd. Chem. Toxicol. 22, 623636.

- Ishizaki, M., N. Oyamada, S. Ueno, K. Katsumura and Y. Hosogai (1979) Mutagenicity of degradation and reaction products of butyll hydroxy anisole with sodium nitrite or potassium nitrite by irradiation of ultra violet ray. Studies on degradation of food additives by irradiation. V, J. Fd. Hyg. Soc. Japan, 20, 143-146.

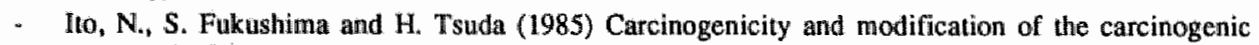
response by BHA, BHT and other antioxidants, CRC Crit. Rev. Toxicol., 15, 109-150.

- Joint FAO/WHO Expert Committee on Food Additives-JECFA (1986) Toxicological evaluation of certain food additives and contaminants. WHO Food Additives Series 21.

- Kahl, R. (1984) Synthetic antioxidants: biochemical actions and interference with radiation, toxic compounds, chemical mutagens and chemical carcinogens, Toxicology, 33, 185-228.

- Kahl, R. and A.G. Hildebrandt (1986) Methodology for studying antioxidant activity and mechanisms of action of antioxidants, Fd. Chem. Toxicol., 24, 1007-1014.

- Kawachi, T., T. Komatsu, T. Kadla, M. Ishidate, M. Sasaki, T. Sugiyama and Y. Tazima (1980) Results. of recent studies on the relevance of various short-term screening test in Japan. In: The predictive value of short-term screening tests in carcinogenicity evaluation. G.M. Williams ef al. (Eds.) Elsevier/NorthHolland Biomedical Press, Amsterdam, pp. 253-266. 
- Levin, D.E., M. Hollstein, M.F. Christman, E.A. Schwiers and B.N. Ames (1982) A new Salmonella tester strain (TA102) with A-T base pairs at the site of mutation, detects oxidative mutagens, Proc. Nall. Acad. Sci. USA, 79, 7445-7449.

- Mamet, L.J., H.K. Hurd, M.C. Hollstein, D.E. Levin, H. Esterbauer and B.N. Ames (1985) Naturally occurring carbonyll compounds are mutagens in Salmonella tester strain TA104, Mutation Res., 148, 25-34.

- Maron, D.M. and B.N. Ames (1983) Revised methods for the Salmonella mutagenicity tost, Mutation Res., 113, 173-215.

- Rahimtula, A. (1983) In vitro metabolism of 3-t-butyll-4-hydroxyanisole and its irreversible binding to proteins, Chem.-Biol. Interact., 45, $125-135$.

- Reddy, B.S., D. Hanson, L. Mathews and L. Sharma (1983) Effect of micro-nutrients, anti-oxidants and related compounds on the mutagenicity of $3,2^{\prime \prime}$-dimethyl-4-aminobipheny $\mathrm{I}_{4}$ a colon and breast carcinogen, Fd. Chem. Toxicol., 21, 129-132.

- Shelef, L.A. and B. Chin (1980) Effect of phenolic antioxidants on the mutagenicity of Aflatoxin B1, Appl. Environ. Microbiol., 40, 1039-1043.

- Sheu, C.W., K.T. Cain, C.J. Rushbrook, T.A. Jorgenson and W.M. Generoso (1986) Tests for mutagenic effects of ammoniated glycyrrhizin, butylated hydroxytoluene, and gum arabic in rodent germ cells, Environ. Mutagenesis, 8, 357-367. 


\title{
Chapter 10
}

\section{Effect of short-term dietary administration of butylated hydroxyanisole on cell kinetic parameters in rat gastro-intestinal tract, assessed by immunocytochemistry and flow cytometry}

\author{
Hans Verhagen, Bert Schutte, Michèle M.J. Reynders, \\ Geert H. Blijham, Foppe ten Hoor and Jos C.S. Kleinjans \\ Carcinogenesis 9 (1988) 1107-1109
}

\begin{abstract}
Groups of five male Wistar rats weighing $306 \pm 17 \mathrm{~g}$, were fed a diet containing $2 \%$ 2(3)-tert-butyl-4-hydroxyanisole (BHA) or basal diet (control group) for 2 weeks. Subsequently, rats received an i.p. injection of $25 \mathrm{mg} / \mathrm{kg}$ bromodeoxyuridine (BrdU), a thymidine analogue, and killed after $4 \mathrm{~h}$. The gastro-intestinal tract was removed and fixed in $70 \%$ ethanol. After pepsin digestion of the fixed tissues, labelled cell nuclei were visualized by means of a monoclonal anti-BrdU antibody technique. Cell kinetic parameters were determined by means of bivariate BrdU/DNA analysis using flow cytometry. Mean labelling index and potential doubling time of forestomach cells were significantly increased and decreased, respectively, $(P<0.002)$ in the $2 \%$ BHA group as compared to control rats. Cell kinetic parameters in other organs - glandular stomach, ileum, caecum and colon were not affected by short-term consumption of BHA.
\end{abstract}

\section{Introduction}

The synthetic food antioxidant 2(3)-tert-butyl-4-hydroxyanisole (BHA) is carcinogenic in the forestomach of rats, hamsters and probably mice (1-3). Sequential changes are dosedependent and involve hyperplasia, papillomas and carcinomas $(4,5)$, the development of which is accompanied by an increase in forestomach labelling index (LI) (6-12). The development of lesions and hyperplasia and the increase in LI appear to be reversible when BHA is removed from the diet after short (13), sub-chronic (7), or long-term (9) oral administration. Species which do not possess a forestomach, e.g. pigs (14) or dogs (15), are generally not susceptible to proliferative effects of BHA, but in primates the mitotic index of the distal oesophagus is increased after 85 days of BHA administration (250-500 $\mathrm{mg} / \mathrm{kg}$ body weight) (16).

Although the tumor growth inducing potential of BHA is well documented, little is known about the carcinogenic mechanism, especially since BHA does not seem to have genotoxic activity (17). Therefore, studies on factors mediating the carcinogenic response to $\mathrm{BHA}$, especially emphasizing early (sub)cellular events may contribute to a better understanding of 
mechanisms underlying the tumorigenicity.

Lis are traditionally determined by $[3 \mathrm{H}]$-thymidine incorporation and subsequent autoradiography (6-11). In contrast, we applied a recently developed technique using the thymidine-analogue bromodeoxyuridine (BrdU) and flow cytometry. By combined measuremient of incorporated BrdU and total DNA a labelled cohort of cells can be followed through the cell cycle which allows the assessment of $\mathrm{LI}_{3}$ potential doubling time (Tpot), and mean transit time through the S-phase (Ts) (18-21). Bivariate BrdU/DNA analysis has made phase fraction analysis based on DNA content a simple and accurate procedure, offering advantages over calculations on the basis of monoparametric DNA-histograms (22). In extension to prewious experiments studying LI's after dietary BHA intake in rodent oesophagus, forestomach and glandular stomach (6-12), dynamic cell kinetic parameters in forestomach, glandular stomach, ileum, caecum and colon were assessed.

Wistar rats have previously not been used for assessment of BHA-increased LI, but develop lesions, hyperplasia and tumors similarly to F344 rats and Syrian golden hamsters $(3,13)$.

\section{Experimental}

Groups of five male Wistar rats (Winkelmarn, Borchem, FRG) weighing $306 \pm 17 \mathrm{~g}$ (mean \pm SD) were housed individually in metabolic cages in an air-conditioned room at $22^{\circ} \mathrm{C}$ and $50 \%$ humidity with a $12 \mathrm{~h}$ light/dark cycle. After 1 week of acclimatization, rats were fed either regular lab chow (control group; $n=5$ ) or this basal diet supplemented with $2 \%$ BHA $(\mathrm{n}=5)$ for a further 2 weeks. Food-grade BHA (purity $>99 \%$; 94.4\% 3-tert-butyl-4-hydroxyanisole) was a generous gift of J. Dekker Company, Wormerweer, The Netherlands. Rats had free access to the powdered diets and drinking water. Food consumption was recorded daily and body weights were measured three times a week. On day 21 rats received an i.p. injection of $25 \mathrm{mg}$ BrdU/ $\mathrm{kg}$ dissolved in $1 \mathrm{ml}$ phosphate-buffered saline. After 4 th they were killed under ether anaesthesia by cervical dislocation. The gastro-intestinal tract (forestomach, glandular stomach, ileum, caecum and colon) was removed; opened longitudinally, cleaned from its contents, fixed in $70 \%$ ethanol and stored at $4{ }^{\circ} \mathrm{C}$.

Determination of cell kinetic parameters was performed using previously described methods (18-20), as modified by Schutte et al. (21). In short, randomized small samples of ethanol-fixed tissues were digested by pepsin (Boehringer, Mannheim, FRG), sieved and treated with $2 \mathrm{~N} \mathrm{HCl}$ for DNA denaturation. Isolated cells were incubated with a monoclonal anti-BrdU antibody (clone 11 B 5, prepared in our laboratory) for $60 \mathrm{~min}$ at room temperature and subsequently incubated with fluorescein-conjugated rabbit anti-mouse IgG-FITC (F313. Dakopatts, Denmark) for 60 min at $4{ }^{\circ} \mathrm{C}$. Total DNA was stained with propidium iodide (Calbiochem, Behring Diagnostics, San Diego, CA). Double stained cells were analysed on a FACS IV cell sorter (Becton and Dickinson, CA) equipped with a 4-W argon ion laser (Spectra Physics, model 164-05) operating at $400 \mathrm{~mW}$ output at $488 \mathrm{~mm}$. A 520 -1p filter was used to block scattered Jight. Log green fluorescence was measured through a 540 - $\mathrm{sp}$ filter and recorded as a measure of the amount of bound antiBrdu antibody. Red fluorescence was measured through a 620 -1p filter and was recorded as a measure of the amount of bound propidium iodide. LI, Tpot and Ts were calculated as described by Begg et al. (20). The limit of detection of $\mathrm{LI}$ is $-0.5 \%$. 


\section{Results and discussion}

Mean food consumption and body weights are shown in Figures $10-1$ and 10-2 respectively. Rats fed a diet supplemented with $2 \%$ BHA reduced their food consumption immediately but returned to normal feeding behaviour within one week. However, their body weights remained below the control level.

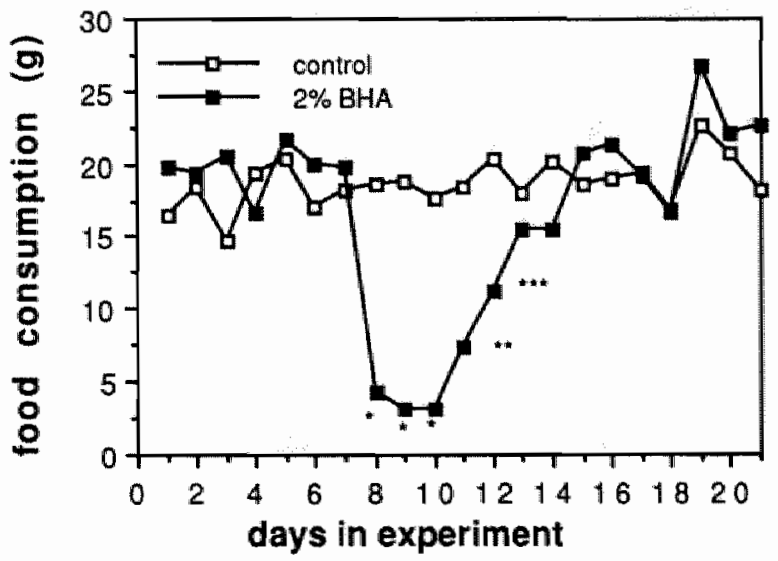

Figure 10-1: Mean daily food consumption by male Wistar rats. Rats were fed basal diet 40 to day 7 and experimental diet ( $2 \%$ BHA) or basal diet (control) thereafter, $p<0.0005\left(^{*}\right), p<0.005\left(^{* *}\right.$ ) or $p<0.01$ ${ }^{* * *}$ ) as compared to control rats; Student t-test for unpaired values.

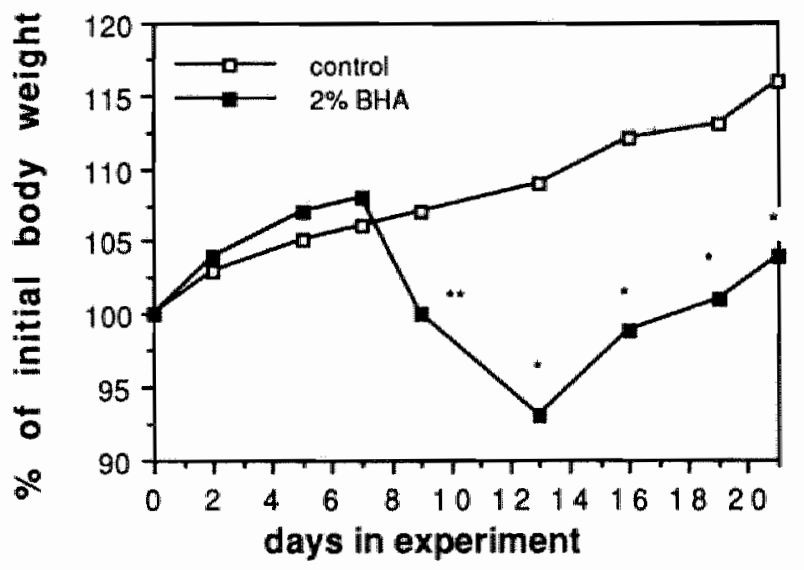

Figure 10-2: Effect of feeding 2\% BHA on mean body weights of male Wistar rats. Rats were fed a basal diet up to day 7 and experimental diet (2\% BHA) or basal diet (control) thereafter.

$p<0.0005(*)$ or $p<0.005(* *)$ as compared to control rats. Student t-lest for unpaired values. 
LI's, Tpot's and Ts" in randomized samples of various gastro-intestinal tract tissues as measured by flow cytometry are presented in Table $10-\mathrm{I}$. Oral application of $2 \%$ BHA significantly increased the mean LI and decreased the mean Tpot of rat forestomach $(P<$ 0.002); Ts was not altered. Other organs were not affected. This indicates that BHA increases the growth fraction of forestomach cells, possibly by affecting regulatory mechanisms of cell replication, but not the velocity of individual cell duplication. However, the possible significance of a decline in food intake and consequent weight loss on cell kinetics in the forestomach is not excluded. This subject is currently under investigation in our laboratory. In the present study LI values of rat forestomach $(10.0 \pm 3.4 \%$ in control rats and $20.7 \pm 3.9 \%$ in $\mathrm{BHA}$ treated rats) fit well within the broad range reported in the literature $(6-12)$.

TABLE 10-1. CELL KINETIC PARAMETERS OF GASTRO-INTESTINAL TRACT TISSUES.

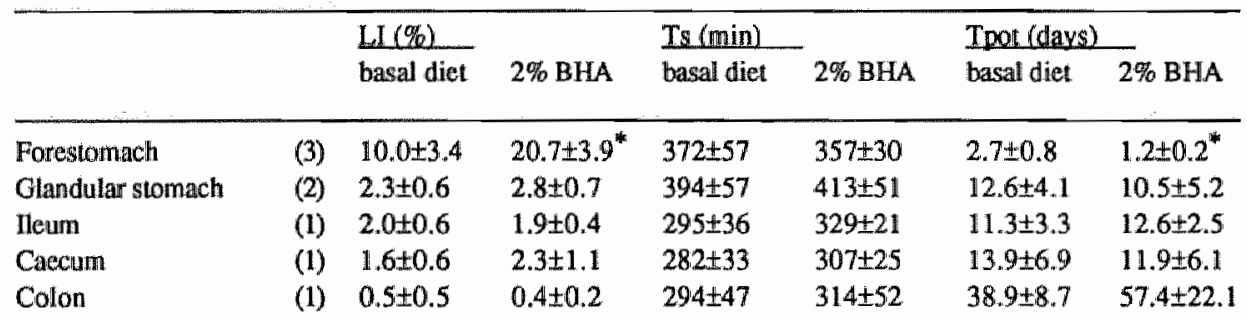

*: Significantly different from control group at $\mathrm{P}<0.002$; Student's $t$-test for unpaired values.

Male Wistar rats were fed a basall diet $(n=5)$ or a basal diet supplemented with $2 \%$ BHA $(n=5)$ for 2 wceks. Parentheses indicate the number of randomly chosen samples taken per tissue of each rat.

Mean values $\pm \mathrm{SD}$.

Although feeding of $2 \%$ BHA has been generally reported to increase rodent forestomach LI, data on LI's of gastro-intestinal tract tissues like forestomach. glandular stomach, and oesophagus in similar experiments vary considerably (6-12), which possibly reflects differences in species, age, body weight, histomorphological locallization of counted cells in the forestomach epithelium, and methods of assessment. In male F344 rats, locations close to the junction with the glandular stomach showed the largest LI, varying between 1 and $4 \%$ in control rats and 6 and $25 \%$ in rats fed BHA. Data on the midregion of the forestomach vary between 0.5 and $2 \%$ and 1 and $8 \%$ for control and BHA-fed rats respectively (6-9). Iverson et al. demonstrated slight increases in LI with age (7). There are no indications of LI alteration as a response to prolonged BHA feeding from 9 days up to 15 months (6-9). Hirose et al $(10,11)$ did not discriminate between prefundic and midregion of the forestomach in Syrian golden hamsters and reported mean LI's of 12.5 and $33.9 \%$ for control animals and hamsters fed BHA respectively. All these studies applied $\left[{ }^{3} \mathrm{H}\right]$ thymidine incorporation and autoradiography. Alternatively, Fukushima et al. (12) measured LI's in rat forestomach by BrdU-incorporation and immunohistochemistry. They reported much higher mean LI's in control and BHA-treated rats in both midregion (22.3 and $18.2 \%$ respectively) and prefundic region (17.8 and $33.3 \%$ respectively) compared with the studies using [ $3 \mathrm{H}]$-thymidine incorporation and autoradiography (6-9). 
Killing the animals $4 \mathrm{~h}$ after BrdU injection instead of $\mathbb{t h}$, as is done in the [ $3 \mathrm{H}$ ]-thymidine incorporation assay, will overestimate the LI by $\sim 20 \%$, because part of the cells have already been through mitosis at that time (calculations not shown). In other reports (6-12) specifically (basal) squamous epithelial cells have been counted, while our method does not discriminate between cell types, since tissue batches were randomly sampled at the macroscopical level. We did not investigate whether our assay procedure has any preference for (basal) epithelial cells. The method, however, allows detailed topographical analysis as well, since the ethanol-fixed tissues may be embedded in paraffin and analysed histomorphologically as usual.

The food antioxidants 3,5,-di-tert-butyl-4-hydroxy-toluene (BHT) and BHA both have tumor-growth-promoting capacity $(1,2)$ and may be ingested simultaneously by man. Especially since other synthetic anti-oxidants, ethoxyquin and propylgallate, increased BHA-induced hyperplasia of rat forestomach (23), co-consumption of BHT may be particularly relevant with respect to BHA-induced increases in rat forestomach $L I$. Therefore a similar group of five rats was fed a diet containing $2 \%$ BHA and $1 \%$ BHT. These rats, however, refused almost all food, their body weights decreased by about one-third, and the animals died within a week. Therefore no cytokinetic data are available for the latter group. In the future this experiment may be repeated using a lower, non-toxic dose of BHT.

All rodent studies so far indicate a significantly increased forestomach LI as a response to high levels of BHA in the diet. We confirm proliferative effects of BHA on rat forestomach as assessed by an alternative method and additionally report a decrease in Tpot following short-term dietary BHA administration, while Ts is not altered. Assessment of LI's by means of BrdU incorporation and flow cytometry may compete favorably with traditional $\left[{ }^{3} \mathrm{H}\right]$-thymidine incorporation and autoradiography techniques, and furthermore provides other relevant cell kinetic parameters.

An increase in LI and decrease in Tpot may be early subcellular markers of the carcinogenic potential of BHA. Therefore further research on factors mediating these dynamic cell kinetic parameters is currently being undertaken in order to elucidate the mechanism of tumorigenicity of $\mathrm{BHA}$.

\section{Acknowledgements}

We appreciate the excellent technical skills of mr. F. Weekers. Mrs. M. Peters is acknowledged for typing the manuscript.

\section{References}

1 Ito N, Fukushimat S and Tsuda H. (1986). Carcinogenicity and modification of the carcinogenic response by BHA, BHT and other antioxidarts. CRC Crit. Rew. Toxicol, 15, 109-150.

2 Anonymous (1984). Final report on the safety assessment of butylated hydroxyanisole.

J. Amer. Coll. Toxicol 3, 83-146.

3 Abraham R, Benitz KF, Patil G and Lyon R. (1986). Rapid induction of forestomach tumors in partially hepatectomized Wistar rats given butylated hydroxyanisole. Exp. Mol. Pathol. 44, 14-20.

4 Ito $\mathrm{N}$, Fukushima S, Tamano S, Hirose $M$, and Hagiwara A. (1986). Dose response in butylated hydroxyanisole indwction of forestomach carcimogenesis in F344 rats. J. Natl. Cancer Inst. 77, 126! . 1265.

5 Masui $T$, Hirose $M$, Imaida $\mathrm{K}$, Fukushima $S$, Tamano $S$ and Ito N. (1986). Sequential changes in the forestomach of $\mathrm{F} 344$ rats, Syrian golden hamsters and $\mathrm{B} 6 \mathrm{C} 3 \mathrm{Fl}$ mice treated wilh butylated hydroxyanisole. Gann 77, 1083 -1090. 
6 Nera E.A., Lal E., lverson $F_{\text {. }}$ Ormsky E, Karpinski KF and Clayson DB. (1984). Short-term pathological and protiferative effects of butylated hydroxyarisole and other phenolic antioxidants in the forestomach of Fischer 344 ratis. Toxicology $32,197-213$.

7 Iverson F, Lok E, Nera E, Karpinski K and Clayson DB. (1985). A 13-week feeding study of butylated hydroxyanisole: the subsequent regression of the induced lesions in male Fischer 344 rat forestomach epithelium. Toxicology $35,1-11$.

8 Rodrigues C, Lok E, Nera E, Iverson F, Page D, Karpinski K and Clayson DB. (1986). Short term effects of various phenols and acids on the Fischer 344 male rat forestomach epithelium. Toxicology 38 , $103 \div 117$.

9 Clayson DB, Iverson F, Nera E, Lok E, Rogers C, Rodrigues C. Page D and Karpinski K. (1986). Histopathological and radioautographical studies on the forestomach of F344 rais treated with butylated hydroxyanisole and related chemicals. Food Chem. Toxicol. 24, 1171-1182.

10 Hirose $M$. Inove $T$, Asamoto $M$, Tagawa $Y$ and Ito $N(1986)$. Comparison of the effects of 13 phenollic compounds in induction of proliferative lesions of the forestomach and increase in the labelling indices of the glandular stomach and urinary bladder epithelium of syrian golden hamsters. Carcinogenesis 7 , 1285-1289.

11 Hirose $M$, Masuda $A$, Kurata $Y$, dkawa E, Mera $Y$ and Ito $N(1986)$. Histologic and autoradiographic studies on the forestomach of hamsters treated with 2-tert-butylated hydroxyanisole, 3-tert-butylated hydroxyanisole, crude butylated hydroxyanisole, or butylated hydroxytoluene. J. Natl. Cancer Inst. 76, $143-149$.

12 Fukushima S, Sakata T, Tagawa $Y$, Shibata M-A, Hirose $M$ and Ito N. (1987). Different modifying response of butylated hydroxyanisole, butylated hydroxytoluene, and other antioxidants in $N, N-$ dibutylnitrosamine esophagus and forestomach carcinogenesis of rats. Cancer Res. 47, 2113-2116.

13 Altmann H-J, Wester PW, Matthiaschk GG, Grunow W and Van der Heijden CA. (1985). Induction of carly lesions in the forestomach of rats by 3-fert-butyl-4-hydroxyanisole (BHA). Food Chem. Toxicol. 23, 723-731.

14 Wurtzen $G$ and Olsen P (1986). BHA study in pigs. Food Chem. Toxicol. 24, 1229-1233.

15 Tobe $M$, Furuya T, Kawasaki $Y$, Naito $K$, Sehita $K$, Matsumoto K, Ochiai T, Usui A, Kokubo T, Kanno J and Hayashi $Y$. (1986). Six-month toxicity study of butylated bydroxyanisole in beagle dogs. Food Chem. Toxicol. 24, 1223-1228.

16 Iverson F, Truelove J, Nera E, Wong I, Lok E and Clayson DB (1985). An 85-day study of butylated hydroxyanisole in the cynomolgus monkey. Cancer Lett. $26,43-50$.

17 Hageman GJ, Verhagen H and Kleinjans JCS (1987). Non-mutagenicity of butylated hydroxyanisole, butylated thydroxytoluene and tert-butylhydroquinone in the Salmonella/microsome assay using new tester strains. Pharmac Weekbl. Sci. Ed, 9, 41.

18 Gratzner H.G. (1982). Monoclonal antibody to 5-bromo and 5-iododeoxyuridine: a new reagent for detection of DNA replication. Science $218,474-475$.

19 Dolbeare $\mathbb{F}_{* n}$ Gratzier $H_{n}$, Pallaviani M.G., and Gray J.W. (1983). Flow cytometric measurement of total DNA content and incorporated bromodeoxyuridine. Proc. Naul. Acad. Sci. USA, 80, 5573-5577.

20 Begg A.C., McNally N.J., Shrieve D.C., and Karcher H. (1985). A method to measure the duration of DNA synthesis and the potential doubling time from a single sample. Cytometry 6, 620-626.

21 Schute B., Reynders M.M.J., Van Assche C.L.M.V.J., Hupperets P.S.G.J., Bosman F.T. and Blijham O.H. (1987). An improved method for the immunocytochemical detection of BrdU labelled nuclei using flow cytometry. Cytometry 8, 372-376.

22 Dean P.N., Dolbeare F., Gratzner H., Rice G.C. and Gray J.W. (1984). Cell-cycle analysis using a monoclonal antibody to BrdUrd. Cell Tissue Kinet. 17, 427-436.

23 Hirose $M_{n}$ Hagiwara $A$., Masui $T$., Inoue $K$. and Ito N. (1986). Combined effects of butylated hydroxyanisole and other antioxidants in induction of forestomach lesions in rats. Cancer Lett. 30, 169 -
174 . 


\title{
Chapter 11
}

Butylated hydroxyanisole-induced alterations in cell kinetic parameters in rat forestomach in relation to its oxidative cytochrome P-450 -mediated metabolism

\author{
Hans Verhagen, Carina Furnée, Bert Schutte, Rob J.J. Hermans, Fré T. Bosman, \\ Geert H. Blijham, Foppe ten Hoor, Peter Th. Henderson and Jos C.S. Kleinjans \\ Carcinogenesis, in press
}

\section{Abstract}

Four groups of six male Wistar rats $(85 \pm 7 \mathrm{~g})$ were fed a diet containing $0 \%$ (control) or $2 \%$ of the carcinogenic food antioxidant butylated hydroxyanisole (BHA) for two weeks. In this experiment, feeding $2 \%$ BHA is equivalent to a dose of $2.1 \pm 0.3 \mathrm{~g} \mathrm{BHA} / \mathrm{kg} / \mathrm{day}$. One $0 \% \mathrm{BHA}$ and one $2 \%$ BHA-fed group of rats were daily injected i.p. with the cytochrome $P$. 450 inducer phenobarbital (PB; $60 \mathrm{mg} / \mathrm{kg}$ ) in saline. These two groups were encoded $0 \mathrm{~PB}$ and $2 \mathrm{~PB}$, respectively. Simultaneously, two control groups of rats were injected $i . p$. with saline only ( 0 and 2 , respectively). PB administration increased relative weight, cytochrome P.450 content and ethoxycoumarin-O-deethylase activity of livers as compared to control rats. In addition, cytochrome P-450 -mediated oxidative demethylation of BHA into tert-butyl-hydroquinone (TBHQ), monitored as urinary TBHQ excretion, was significantly increased in $\mathrm{PB}$-induced rats as compared to non-induced rats $(0.59 \pm 0.19 \%$ vs $0.37 \pm 0.09 \% ; p<0.05)$. The mean labelling index (LI) and potential doubling time (Tpot) in rat forestomach were significantly $(p<0.01)$ altered in groups of rats fed $2 \%$ BHA as compared to their appropriate control groups. No difference in cell kinetic parameters between either the two control groups $(0,0 P B)$ or between the $2 \%$ BHA-fed groups $(2,2 \mathrm{~PB})$ was observed. Thus, although an increase in oxidative demethylation of $\mathrm{BHA}$ as a response to $\mathrm{PB}$ administration is evident, biotransformation of BHA into $\mathrm{TBHQ}$ is not correlated to changes in cell kinetic parameters in rat forestomach. Moreover, in rats oxidative cytochrome P-450 -mediated demethylation of BHA into TBHQ appears not to be related to the oral dose of BHA. This indicates that oxidative cytochrome P-450-mediated biotransformation of BHA does not contribute to the tumorigenicity of BHA in rat forestomach. 


\section{Intraduction}

The food antioxidant 2(3)-tert-butyl-4-hydroxyanisole (BHA) is a potent modulator of chemically induced mutagenesis and carcinogenesis (1-6). Furthemore, BHA is a complete carcinogen in the forestomach of rats, hamsters and probably mice $(1,6,7,8)$ and $\mathrm{BHA}$ induces proliferation enhancing effects in the oesophageal mucosa of pigs (9) and monkeys $(10)$, but not of dogs $(11,12)$. Dose-dependent changes in rodent forestomach (hyperplasia, papillomas and carcinomas) are accompanied by an increase in labelling index (LI)(13-21) and a decrease in potential doubling time (Tpot)(21). Therefore, these cell kinetic parameters can be used as early markers of the carcinogenic potential of $\mathrm{BHA}$, which may be helpful in elucidating the unknown mechanism underlying the tumorigenicity of BHA.

BHA has no mutagenic activity (22), but covalent binding to proteins and nucleic acids has been demonstrated following biotransformation of BHA in vitro and in vivo (23-26). Occurrence of unidentified sulphur-containing metabolites of BHA has been reported, in vivo in rats as well as in vitro, indicating the possibility of reactive species formation $(23,24)$.

In vivo, BHA is mainly conjugated with glucuronic acid and sulphate and subsequently excreted into urine, as has been shown in man and laboratory animals $(2,6,27,28)$. Recently, we reported that approximately $10 \%$ of a single oral dose of $\mathrm{BHA}$ in man ( 0.5 $\mathrm{mg} / \mathrm{kg})$ as well as in rat $(200 \mathrm{mg} / \mathrm{kg})$ is excreted in urine as conjugates of its cytochrome P450-mediated demethylated metabolite tert-butyl-hydroquinone (TBHQ) (28), Oxidative demethylation of BHA has also been demonstrated in vitro, simultaneously with covalent binding of BHA to (sub)cellular protein, suggesting a role of cytochrome P-450 in the possible bioactivation of $\mathrm{BHA}$ into reactive intermediates $(23,24,29)$. In rats, administration of $2 \% \mathrm{TBHQ}$ in the diet induced hyperplasia of the forestomach mucosa, although to a lesser extend than BHA (30), and 1\% TBHQ in the diet gave rise to a significant 1.61 fold increase in forestomach $\mathrm{LI}(14)$.

In the present study it is hypothesized that, if TBHQ formation in vivo, after oral administration of BHA, correlates with an increased LI (resp. decreased Tpot) in rat forestomach, the involvement of cytochrome P-450 in the bioactivation of BHA into its ultimate carcinogenic form is indicated. Subsequently, risk assessment for human BHA consumption would be supported by comparing its biological fate in man vs rat (28).

Phenobarbital (PB), a well-known cytochrome P-450 inducer (31), induces isozymes contributing to the biotransformation of BHA to TBHQ in vitro $(23,29)$. Thus, administration of $\mathrm{PB}$ simultaneously with feeding $\mathrm{BHA}$ in the diet of rats, may increase the amount of TBHQ-formation in vivo. Therefore, in the present study, the biotransformation of BHA, especially its cytochrome $\mathrm{P}-450$-mediated O-demethylation into TBHQ, with or without induction of cytochrome $\mathrm{P}-450$ by additional PB administration, is monitored in rats fed $2 \%$ BHA in the diet for two weeks. Concomitant with the monitoring of the metabolism of BHA, cell kinetic parameters in the forestomachs of these rats are determined by flow cytometry/ immunocytochemistry and compared with appropriate control groups (21). 
alterations in forestomach $L I$ \& metabolism of BHA

\section{Methods}

Male Wistar rats (Winkelmann, Borchem, FRO), five weeks old ( $85 \pm 7 \mathrm{~g}$; mean \pm SD), were housed individually in metabolic cages in an air-conditioned room at $22^{\circ} \mathrm{C}$ and $50 \%$ humidity with a $12 \mathrm{~h}$ light/dark cycle. Following two days of acclimatization, rats were randomly divided into four groups of six rats each. One group was fed regular lab chow and rats were injected i.p. each day with $2 \mathrm{~mL} / \mathrm{kg}$ saline $(0.9 \% \mathrm{NaCl})$ (encoded: O-PB). The second group was fed this basal diet as well, but rats were injected i.p. daily with 2 $\mathrm{ml} / \mathrm{kg}$ of sodium-PB in saline (OPB). Furthermore, groups three and four were injected i.p. every day with, respectively, $2 \mathrm{ml} / \mathrm{kg}$ saline or sodium-PB in saline; these rats were fed a diet containing $2 \% \mathrm{BHA}$ (encoded: 2 and $2 \mathrm{~PB}$, respectively). Sodium-PB was administered in a dose of $60 \mathrm{mg} / \mathrm{kg}$ body weight, when applicable. All rats had free access to the powdered diets and drinking water. Food consumption was recorded daily; body weights were measured three times a week. 48 -hours urine samples for the determination of excretion of BHA and TBHQ were collected on four separate occasions (days 4 and 5,6 and 7,11 and 12,13 and 14). Urinary volume was measured and aliquots were stored at $-20{ }^{\circ} \mathrm{C}$ until analysis.

On the $14^{\text {th }}$ day of the experimental diet, the animals were injected i.p. with $1 \mathrm{ml}$ of $7.5 \mathrm{mg} / \mathrm{ml}$ bromodeoxyuridine (BrdU) in phosphate-burfered saline. After four hours, rats were sacrificed under ether anaesthesia by exsanguination via the aorta. Forestomachs were dissected, cut longitudinally, cleancd, fixed in $70 \%$ ethanol and stored at $4{ }^{\circ} \mathrm{C}$. Livers were excised, cleaned, weighed, immediately frozen in liquid mitrogen and stored at $-80^{\circ} \mathrm{C}$ for the preparation of microsomes.

Determination of cell kinetic parameters in rat forestomach (LI, Tpot and mean transit time through the Sphase of cells [Ts]) was performed as previously described $(21,32)$. Tpot and Ts were calculated according to Begg et al. (33). The detection limit for the $L I$ is approximately $0.5 \%$.

For the determination of total-BH.A (i.e. conjugated BHA \& unconjugated BHA) and total-TBHQ in urine of $2 \%$ BHA-fed rats, previously reported methods were slightly modified, in order to improve the efficiency of analysis (28,34). In short, urine was centrifuged for $10 \mathrm{~min}$ at $2000 \mathrm{~g}$. $10 \mathrm{mg}$ limpet acetone powder (type I, Sigma) were carefully weighed into a glass stoppered tube. Subsequently, $50 \mu l$ of urine was added and diluted to $1 \mathrm{ml}$ with $1 \mathrm{~N}$ sodium-acetate buffer $\mathrm{pH} 4.8 .100 \mu \mathrm{l} \%$ ascorbic acid/1\% EDTA and $100 \mu \mathrm{I}$ methanol, containing $2.5 \mathrm{mg} / \mathrm{ml}$ tri-methylhydroquinone (MHQ) as an internal standard, were added. Tubes were saturated with $\mathrm{N}_{2}$ and incubated overnight at $37^{\circ} \mathrm{C}$, in order to deconjugate the glucuronic acid- and sulphate-conjugates of BH.A and TBHQ. On the next day samples were extracted with $5 \mathrm{mul}$ ether for $20 \mathrm{~min}$ and centrifuged at $700 \mathrm{~g}$ for $5 \mathrm{~min}$. The organic phase was separated and evaporated to dryness under a gentle stream of $\mathrm{N}_{2}$ at $0{ }^{\circ} \mathrm{C}$. The residue was dissolved in $1 \mathrm{ml}$ eluent containing $1 \%$ ascorbic acid and stored under $\mathrm{N}_{2}$ at $4{ }^{\circ} \mathrm{C}$ until analysis (within 24 hours). For the determination of free-BHA (i.e. unconjugated BHA) and free-TBHQ, the procedure was the same except for the addition of limpet acetone powder and the ovemight incubation step.

High-performance liquid chromatography (HPLC) analysis of levels of BHA and TBHQ in urine was performed as follows. $20 \mu$ of the dissolved residue were injected onto a LiChrosorb 5-RP-18 column, which was cluted with methanol/water/acetic acid $(53 / 46 / 1, \mathrm{v} / \mathrm{w} / \mathrm{v})$ at a flow rate of $2 \mathrm{ml} / \mathrm{min}$. A fluorescence detector set at $290 \mathrm{~nm}$ excitation wavelength equipped with a cut-off filter $(360 \mathrm{~nm})$ was used to monitor the effluent. Retention times for MHQ. TBHQ and BHA were $1.5,2.5$ and $7.4 \mathrm{~min}_{\text {respectively. Since rather }}$ high levels of metabolites of BHA were present in rat urine, no interferences with other components were encountered.

Excretion of metabolites of BHA into urine is expressed as $\mathrm{mg} / \mathrm{kg} / \mathrm{day}$ and as percentage of the amount of BHA ingested, calculated on basis of food (and consequently BHA) consumption during the perind of urine collection.

Microsomal suspensions of rat liver were prepared according to Burke and Orrenius (35). Cytochrome P-450 content of pooled liver microsomes was determined by dithionite difference spectra as described by Rutten et al. (36), based on a modification of the Omura and Sato method (37,38). Microsomal deethylase activity (EC-OD) was determined fluorimetrically using 7-ethoxycoumarin as substrate, as described by Greenlee and Polland (39). Microsomal protein content was measured according to Lowry et al. (40), using bovine serum albumin as standard.

Students $t$-test for unpaired values was applied to assess the statistical significance of differences between $2 \%$ $\mathrm{BHA}$-fed groups (2 and $2 \mathrm{~PB}$ ) and their appropriate controls $(0$ and $0 \mathrm{~PB}$, respectively) as well as between the two control groups (0 vs OPB) and the two $2 \%$ BHA-fed groups (2 vs $2 \mathrm{~PB}$ ). $\mathrm{P}<0.05$ is cornsidered significant. 


\section{Results and discussion}

Irnmediately after the onset of the administration of BHA, rats in the 2 and $2 \mathrm{~PB}$ group decreased their food intake considerably, probably due to non-palatability of the diet. After several days their food consumption was more or less constant but remained below control levels over the complete experimental period. Rats on a control diet consumed significantly higher amounts of food ( $\mathrm{p}<0.001$ ) as compared to the $2 \%$ BHA-fed groups. There was a small but significant difference $(p<0.05)$ in food consumption between the two control groups; rats injected with PB ate slightly more than rats injected with saline only. There appeared to be no difference in food consumption between the two groups fed a BHAcontaining diet. these results are illustrated in Figure 11-1.

The caloric intake in all groups was reflected by the body weight throughout the experiment. In both control groups the body weight increased steadily. Rats in the OPB group grew a little, although not significantly, better than rats in the 0 group. In contrast to these control rats, body weights of rats in the 2 and $2 \mathrm{~PB}$ group decreased immediately following administration of BHA, as a result of reduced food intake during the first days; from day 3 on their mean body weight increase was steady, but remained below control levels during the entire experiment. There was no difference in mean body weight between the two BHAfed groups. These tesults are illustrated in Figure 11-2. Changes in body weight owing to food consumption behaviour are comparable with our previous results (21).

The LI, Tpot and Ts determined in randomized samples of forestomach tissue are presented in Table 11-I. After two weeks, the LI and Tpot were significantly altered in rats fed a diet containing $2 \%$ BHA in comparison with rats on a control diet. There appeared to be no significant difference between the two control groups ( 0 vs $0 \mathrm{~PB})$ nor between the $2 \% \mathrm{BHA}$ fed groups ( 2 vs $2 \mathrm{~PB}$ ). Ts was not altered. The cell kinetic results are in agreement with our preceding experiments (21). The $\mathrm{LI}$ in rat forestomach was in range with data reported by others (3,14-18). It is concluded that additional PB administration does not influence BHAinduced increase in $\mathrm{LI}$ in the rat forestomach.

Induction of phase-I biotransformation enzymes by $\mathrm{PB}$ was demonstrated by increases in relative liver weight, cytochrome P-450 content, and EC-OD activity of rat liver microsomes (Table 11-II). BHA also increased relative liver weight, but did not elevate cytochrome P450 content or EC-OD activity.

Excretion into urine of BHA and its demethylated metabolite TBHQ, either as free-BHA and free-TBHQ or conjugated with glucuronic acid or sulphate, is shown in Table 11-III. Generally, toward the end of the experiment in the $2 \%$ BHA-fed groups, there was an increase in the excreted amounts of free-TBHQ $(0.4 \pm 0.1 \%$ to $0.6 \pm 0.3 \%)$, total-TBHQ $(0.3 \pm 0.2 \%$ to $0.6 \pm 0.3 \%)$ and total-BHA ( $36 \pm 9 \%$ to $54 \pm 16 \%$ ), while excretion of freeBHA declined from $1.1 \pm 0.7 \%$ to $0.6 \pm 0.6 \%$. This could be indicative of an on-going induction of cytochrome P- 450 enzymes by PB and phase-II biotransformation enzymes by BHA $(2,6,29)$ and/or of an accumulation of BHA and/or its metabolites in the rat. However, these trends were statistically not significant.

There appeared to be no difference in the levels of total-BHA in urine between PB-induced and non-induced rats (Table 11-III). Excretion of total-BHA into urine accounted for 45$48 \%$ of the ingested amount of BHA (i.e. $1.0 \pm 0.2 \mathrm{~g} / \mathrm{kg} /$ day); only 10 to $25 \mathrm{mg} / \mathrm{kg} / \mathrm{day}$ $(0.47-1.14 \%)$ was detected as free-BHA. Feces were not analyzed in this study, but are likely to contain considerable amounts of free-BHA (28). 


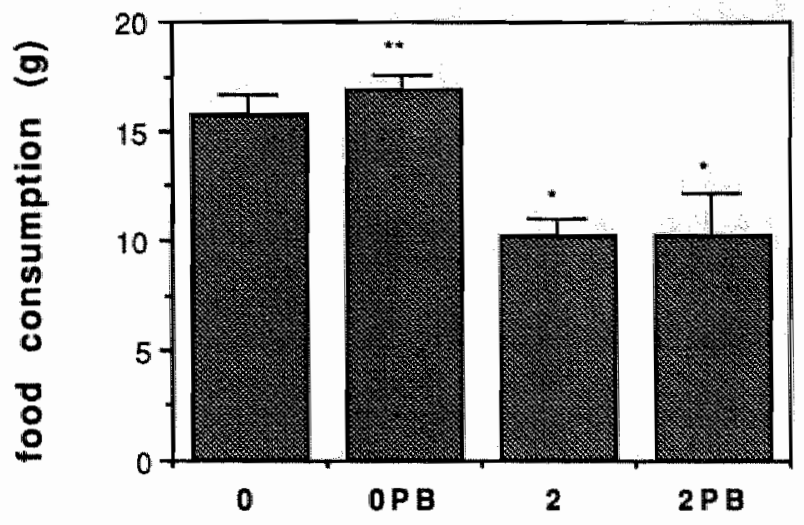

Figure 11-1: Mean daily food consumption by male Wistar rats fed an experimental diet containing 0 or $2 \%$ $B H A$ for a period of fourteen days. Rats were injected i.p. daily either with $P B$ in saline $(+P B)$ or with saline only $(-P B)$. Mean values $\pm S D$.

$*: P<0.001$ ws the appropriate control group; ** "P<0.05 ws 0 group.

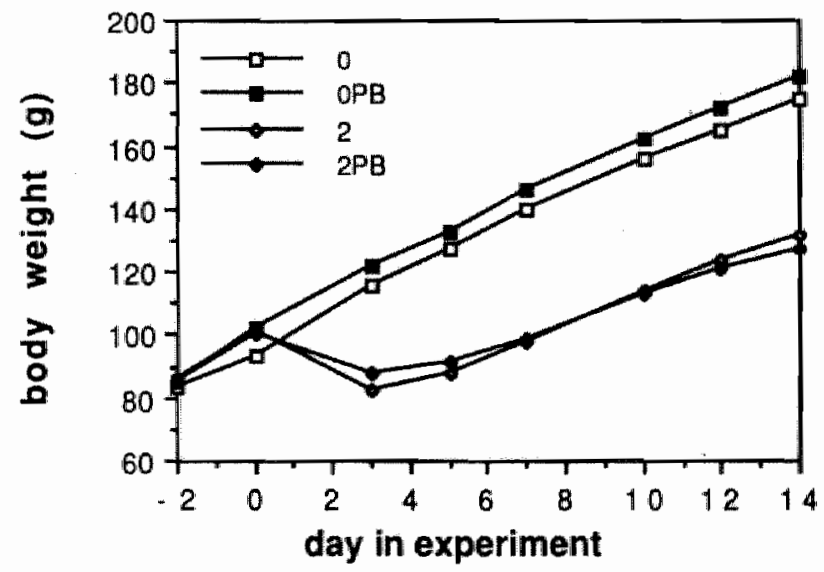

Figure 11-2: Effect of feeding 2\% BHA for two weeks an mean body weights of male Wistar rats as compared to rats on a control diet $(O S B H A)$. Rats were either injected i.p. daily with saline or with saline containing $P B$. 
TABLE 11-1: CELL KINETIC PARAMETERS IN RAT FORESTOMACH.

\begin{tabular}{llll}
\hline $\begin{array}{l}\text { experimental group } \\
\text { of rats }\end{array}$ & $\mathrm{LI}(\%)$ & Tpot (days) & Ts (min) \\
\hline 0 & $12.3 \pm 3.1$ & $2.4 \pm 0.9$ & $378 \pm 40$ \\
OPB & $13.8 \pm 4.5$ & $2.2 \pm 0.7$ & $405 \pm 35$ \\
2 & $\begin{array}{l}20.3 \pm 3.4 \\
(p<0.002 \text { vs } 0)\end{array}$ & $\begin{array}{l}1.3 \pm 0.3 \\
(p<0.02 \text { vs O) }\end{array}$ & $338 \pm 28$ \\
& $22.8 \pm 5.2$ & $1.1 \pm 0.3$ & $341 \pm 54$ \\
$2 \mathrm{~PB}$ & $(p<0.02$ vs OPB $)$ & $(p<0.01$ vs OPB $)$ & \\
& &
\end{tabular}

Malle Wistar rats were fed a basal diet with $(2,2 \mathrm{~PB})$ or without $(0,0 \mathrm{~PB}) 2 \%$ BHA for two weeks. Rats were injected i.p. daily with PB (OPB, $2 \mathrm{~PB})$ in saline or with saline only $(0,2)$. Mean values $\pm S D$.

TABLE 11-II: PARAMETERS OF LIVER ENZYME INDUCTION.

\begin{tabular}{lllll}
\hline parameter & 0 & OPB & 2 & 2PB \\
\hline $\begin{array}{l}\text { relative liver weight } \\
\text { (\% of body weight) }\end{array}$ & $5.4 \pm 0.4$ & $\begin{array}{l}6.7 \pm 0.5 \\
(\mathrm{p}<0.001 \text { vs } 0)\end{array}$ & $\begin{array}{l}6.9 \pm 0.5 \\
(\mathrm{p}<0.001 \text { vs } 0)\end{array}$ & $\begin{array}{l}7.6 \pm 0.6 \\
(\mathrm{p}<0.02 \text { vs } 0 \mathrm{~PB} \text {, } \\
\mathrm{p}<0.05 \text { ws } 2)\end{array}$ \\
$\begin{array}{l}\text { cytocthrome P-450 } \\
\begin{array}{l}\text { content } \\
\text { (nmol/ming protein) }\end{array}\end{array}$ & 0.79 & 1.28 & 0.64 & 1.17 \\
$\begin{array}{l}\text { EC-OD activity } \\
\text { (nmol product/min/mg protein) }\end{array}$ & 1.11 & 2.00 & 0.92 & 2.20 \\
\hline
\end{tabular}

a: Values for pooled liver microsones of six rats.

Male Wistar rats were fed a basal diet with $(2,2 \mathrm{~PB})$ or without $(0,0 \mathrm{~PB}) 2 \%$ BHA for two weeks. Simultaneously, rats were injected i.p. with $\mathrm{PB}(\mathrm{PBB}, 2 \mathrm{~PB})$ in saline or with saline only $(0,2)$. Mean values $\pm \mathrm{SD}$.

TABLE 11-III: EXCRETION OF BHA AND METABOLITES INTO URINE.

\begin{tabular}{lll}
\hline metabolites & 2 & $2 \mathrm{~PB}$ \\
\hline free TBHQ & $0.36 \pm 0.16^{\mathrm{a}}$ & $0.54 \pm 0.11^{\mathrm{b}}$ \\
total TBHQ & $0.37 \pm 0.09$ & $0.59 \pm 0.19^{\mathrm{b}}$ \\
free BHA & $0.47 \pm 0.18$ & $1.14 \pm 0.78$ \\
total BHA & $45.8 \pm 5.3$ & $48.2 \pm 9.9$
\end{tabular}

a: Values are expressed as percentage of the amount of BHA ingested during the period of urine collection. b: Significantly different from the 2 group at $p<0.05$.

Male Wistar rats were fed a diet containing $2 \%$ BHA for two weeks. Rats were injected i.p. daily with PB (2PB) or with saline (2). Urine was collected on eight days during this period. Mean values $\pm \mathrm{SD}$. 
Average urinary excretion of TBHQ, calculated over eight days in the experimental period, was significantly increased in the $2 \mathrm{~PB}$ vs the 2 group. This demonstrates that PB induces hepatic cytochrome $\mathrm{P}-450$ isozymes that take part in the biotransformation of BHA into its O-demethylated metabolite TBHQ. On average, rats consumed $2.1 \pm 0.3 \mathrm{~g} \mathrm{BHA} / \mathrm{kg} / \mathrm{day}$. Only 8 to $13 \mathrm{mg} / \mathrm{kg} /$ day (i.e. 0.37 to $0.59 \%$ of the ingested amount of BHA) were converted into TBHQ, as monitored by its urinary excretion. Previously, we reported that $17.8 \pm 7.0$ $\mathrm{mg} / \mathrm{kg}$ of a single oral dose of BHA of $200 \mathrm{mg} / \mathrm{kg}$ (i.e. $8.9 \pm 3.5 \%$ ), excreted mainly over a period of two days, were metabolized into TBHQ in rat (28). Thus, the ten-fold difference in dose is not reflected by a comparable increase in absolute amounts of TBHQ formed in vivo. This discrepancy may be explained by an uncoupling of the cytochrome P-450 from its reductase at high concentrations of BHA in vivo, thereby blocking its own oxidative metabolism, as described by Cummings et al. (23) to occur in vitro. Indeed, BHA has been proven to be a potent inhibitor of cytochrome P- 450 mediated biotransformation by a mechanism of 'type I' binding in vitro (41). The relatively minor excretion of 'TBHQ is not due to mal-absorption of BHA from the gastro-intestinal tract, since in rats a dose of $2 \mathrm{~g} / \mathrm{kg}$ may be readily absorbed, as reported by Guarna et al. (42).

In contrast to our previous findings (28), TBHQ is excreted in its unconjugated form. This may be the result of the relatively higher amount of BHA ingested by the rats in this study, indicating a saturation or exhaustion of phase-II biotransformation pathways by BHA itself. Others have reported that in rats administration of $2 \%$ TBHQ in the diet induced hyperplasia of the forestomach mucosa, although to a lesser extend than BHA (30), and 1\% TBHQ in the diet gave rise to a significant 1.61 fold increase in forestomach LI (14). In hamster forestomach, the LI was also increased after administration of $0.5 \% \mathrm{BHA}$ in the diet, although differences were statistically not significant, which could have resulted from the small number of animals used $(n=3)$, however (18).

From our experiments, it is concluded that oxidative demethylation of BHA as monitored by urinary excretion of TBHQ in rats, does not increase dose-dependently after oral BHA administration, but is elevated after cytochrome P-450 induction. However, since the forestomach $\mathrm{LI}$ is not affected by increased BHA O-demethylation, it is unlikely that the carcinogenicity of BHA in rodent forestomach is related to this biotransformation pathway in vivo. This conclusion is strengthened by the fact that BHA is not mutagenic in the Salmonella/microsome assay, with or without the addition of an S9-mix (22).

However, in the present study protocol, effects of PB on biotransformation of BHA could reflect metabolism in the liver and not in the forestomach. DeStafney et al. (24) reported an unknown metabolite of BHA formed exclusively in the forestomach of rats, possibly a sulphur-containing metabolite $(23,24)$. Further, bioactivation of BHA may still contribute to BHA-induced forestomach carcinogenesis by the formation of other metabolites of BHA, with possible specific reactivity towards forestomach tissue macromolecules. It has been reported that tert-butyl-quinone (TBQ) and 3-tert-butyl-5-methoxy-1,2-benzoquinone may react with rat tissue macromolecules in vivo and in vitro, possibly wia the formation of reactive oxygen species through redox-cycling $(23,24,26,29)$.

Alternatively, not the formation of TBHQ or TBQ could provide the ultimate carcinogen, but the other reaction product of oxidative demethylation, formaldehyde may also give rise to macromolecule binding. In experiments with radio-isotope-labelled BHA, in rats covalent nucleic acid-binding was observed when this label was attached to the O-methyl moiety of BHA. However, this was only demonstrated in liver, kidney and glandular stomach and not in the forestomach (26).

Summarizing, oxidative cytochrome P-450 -mediated biotransformation of BHA into TBHQ does most probably not contribute to the induction of proliferative changes and 
twmorigenicity in rodent forestomach. Future research on the mechanism underlying the carcinogenicity of $\mathrm{BHA}$ will have to focus on other aspects.

\section{References}

1 Ito N., Fukushima S. and Tsuda H. (1986). Carcinogenicity and modification of the carcinogenic response by BHA, BHT and other antioxidants. CRC Crit. Rev. Toxicol. 15, 109-150.

2 Anonymous (1984). Final report on the safety assessment of butylated hydroxyanisole. J.. Am. Coll. Toxicol. $3,83-146$.

3 Fukushima S.., Sakata T, Tagawa Y., Shibata M.A., Hirose M. and Ito N. (1987). Dilferent modifying response of butylated hydroxyanisole, butylated hydroxytoluene, and other antioxidants in $\mathbb{N}_{\mathrm{g}} \mathrm{N}$ dibutylnitrosamine esophagus and forestomach carcinogenesis of rats. Cancer Res. 47, 2113-2116.

4 Hocman G. (1988). Chemoprevention of cancer: phenolic antioxidants (BHT, BHA). Int. J. Biochem. $20,639-651$.

5 Waltenberg L.W. (1985), Chemoprevention of cancer. Cancer Res. 45, 1-8.

6 Anonymous (1986). Butylated hydroxyanisole (BHA). IARC Monographs on the evaluation of the carcinogenic risk of chemicals to man. $40,123-159$.

7 Abraham R., Benitz K.F., Patil G. and Lyon R. (1986). Rapid induction of forestomach tumors in partially hepatectomized Wistar rats given butylated hydroxyanisole. Exp. Mol. Pathol, 44, 14-20.

8 Ito N., Fukushima S., Tamano S., Hirose M., and Hagiwara A. (1986). Dose response in butylated hydroxyanisole induction of forestomach carcinogenesis in F344 rats. J.Natl.Cancer Inst. 77, 12611265.

9 Würtzen $G$. and Olsen P. (1986). BHA study in pigs. Food Chem. Toxicol. 24, 1229-1233.

10 Iverson F., Truelove J., Nera E., Wong J., Lok E. and Clayson D.B. (1985). An 85-day study of butylated hydroxyanisole in the cynomolgus monkey. Cancer Lett. 26, 43-50.

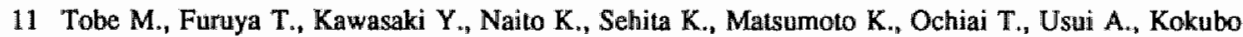
T., Kanno J. and Hayashi Y. (1986). Six-month toxicity study of butylated hydroxyanisole in beagle dogs. Food Chem. Toxicol. 24, 1223-1228.

12 Ikeda G.J., Stewart J.E., Sapienza P.P., Peggins III J.O., Michel T.C., Olivito V., Alam H.Z. and O'Donell M.W. Jr. (1986). Effect of subchronic dietary administration of butylated hydroxyanisole on canine stomach and hepatic tissue. Food Chem. Toxicol. 24, 1201-1221.

13 Masui T., Hirose M., Imaida K.. Fukushima S., Tamano S. and Ito N. (1986). Sequential changes in the forestomach of F344 rats, Syrian golden hamsters and B6C3F1 mice treated with butylated hydroxyanisole. Gann 77, 11083-1090.

14 Nera E.A., Lok E., Iwerson F., Ormsky E., Karpinski K.F. and Clayson D.B. (1984). Short-term pathological and proliferative effects of butylated hydroxyanisole and other phenolic antioxidants in the forestomach of Fischer 344 rats. Toxicology 32, 197-213.

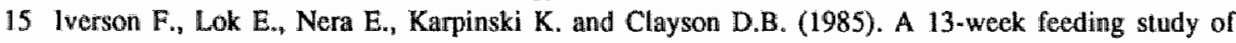
butylated hydroxyanisole: the subsequent regression of the induced lesions in malle Fischer 344 rat lorestomach epithelium. Toxicology 35, 1-11.

16 Rodrigues C., Lok E., Nera E., Iverson F., Page D., Karpinski K. and Clayson D.B. (1986). Short term effects of various phenols and acids on the Fischer 344 male rat forestomach epithelium. Toxicology 38, $103-117$.

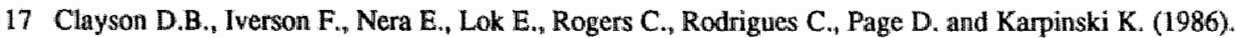
Histopathological and radioautographical studies on the forestomach of F344 rats treated with butylated hydroxyanisole and related chemicals. Food Chem. Toxicol. 24, 1171-1182.

18 Hirose M., Inoue T. Asamoto M., Tagawa Y. and Ito N. (1986). Comparison of the effects of 13 phenolic compounds in induction of proliferative lesions of the forestomach and increase in the labelling indices of the glandular stomach and urinary bladder epithelium of syrian golden hamsters. Carcinogenesis 7, 1285-1289. 


\section{alterations in forestomach $L I$ metabohsm of BHA}

19 Hirose M., Masuda A., Kurata Y., Ikawa E., Mera Y. and Ito N. (1986). Histologic and autoradiographic studies on the forestomach of hamsters treated with 2-teri-butylated hydroxyanisole, 3-tert-butylated hydroxyanisole, crude butylated hydroxyanisole, or butylated hydroxytoluene. J Natl.Cancer Inst. 76, 143-149.

20 Altmann H.-J., Wester P.W., Matthiaschk G.G., Grunow W. and van der Heijden C.A. (1985). Induction of early lesions in the forestomach of rats by 3-tert-butyl-4-hydroxyanisole (BHA). Food Chem. Toxicol. 23, 723-731.

21 Verhagen H., Schutte B., Reynders M.M.J., Blijham G.H., ten Hoor F. and Kleinjans J.C.S. (1988). Effect of short-term dietary administration of butylated hydroxyanisole on cell kinetic paranneters in rat gastro-intestinal tract, assessed by immunocytochemistry and flow cytometry. Carcinogenesis 9.1107 . 1109 .

22 Hageman G.J., Verhagen H. and Kleinjans J.C.S. (1988), Butylated hydroxyanisole, butylated hydroxytoluene and tert-butylhydroquinone are not mutagenic in the Salmonella/microsome assay using new tester strains. Mut. Res. 208, 207-211.

23 Cummings S.W., Ansari G.A.S., Guengerich F.P., Crough L.S. and Prough R.A. (1985). Metabolism of 3-tert-butyl-4-hydroxyanisole by microsomal fractions and isolated rat hepatocytes. Cancer Res. 45 , $5617-5624$

24 DeStafney C.M., Prabhu U.D.G., Sparnins V.L. and Wattenberg L.W. (1986). Studies related to the mechanism of 3-BHA-induced neoplasia in the rat forestomach. Food Chem. Toxicol. 24, 1149-1157.

25 Rahimtula A. (1983). In vitro metabolism of 3-tert-butyl-4-hydroxyanisole and its irreversible binding to proteins. Chem.-Biol. Interact. 45, 125-135.

26 Hirose M., Asamoto M., Hagiwara A., Ito N., Kaneko H., Saito K., Takamatsu Y., Yoshitake A., and Miyamoto J. (1987). Metabolism of 2- and 3-tert-butyl-4-hydroxyanisole (2- and 3-BHA) in the rat (II): melabolism in forestomach and covalent binding to tisste macromolecules. Toxicology 45, 13-24.

27 Conning D.M. and Phillips J.C. (1986). Comparative metabolism of BHA, BHT and other phenolic antioxidants and its toxicological relevance. Food Chem Toxicol. 24, 1145*1148.

28 Verhagen H., Thijssen H.H.W., ten Hoor F, and Kleinjans J.C.S. (1989) Disposition of single oral doses of butylated hydroxyanisole in man and rat." Food Chem. Toxicol. 27, 151-158.

29 Cummings S.W. and Prough R.A. (1983). Butylated hydroxyanisole-stimulated NADPH oxidase activity in rat liver microsomal fractions. J. Biol. Chem. 258, 12315-12319.

30 Altmann H.J., Grunow W., Mohr U., Richter-Reichhelm H.B. and Wester P.W. (1986). Effects of BHA and related phenols on the forestomach of rats. Food Chem. Toxicol. 24, 1183-1188.

31 Sipes I.G. and Gandolfi A.J. (1986). Biotansformation of toxicants. in: Casaret and Doull's Toxicology. The basic science of poisons. (C.D. Klaassen, M.O. Amdur and J. Doull, Eds.), third ed, Macmillan Publishing Company, New York, p64.98.

32 Schutte B., Reynders M.M.J., Van Assche C.L.M.V.J., Hupperets P.S.G.J., Bosman F.T. and Blijham G.H. (1987). An improved method for the immunocytochemical detection of BrdU labelled nuelei using flow cyiometry. Cytometry 8, 372-376.

33 Begg A.C., McNally N.J., Shrieve D.C., and Karcher H. (1985). A method to measure the duration of DNA synthesis and the potential doubling time from a single sample. Cytometry 6,620-626.

34 Verhagen H. "Thijssen H.H.W. and Kleinjans J.C.S. (1987) Sensitive high-performance liquid chromatographic method for the routine determination of butylated hydroxyanisole in plasma. J. Chromatogr. 413, 282-286.

35 Burke M.D. and Orrenius $S_{n}$ (1979). Isolation and comparison of endoplasmatic reticulum membranes and their mixed function oxidase activities from mammalian extrahepatic tissues. Pharmac. Ther. 7 . 549-599.

36 Rutien A.A.J.J.L., Falke H.E., Catsburg J.F., Topp R., Blaauboer B.J., van Holsteijn I., Doorn L. and van Leeuwen F.X.R. (1987). Interlaboratory comparison of total cytochrome P-450 and protein determinations in rat liver microsomes. Arch. Toxicol. 61, 27-33.

37 Matsubara T., Masahiro K., Akira T., Yoshihiro T. and Sugeno K. (1976). Quantitative determination of cytochrome $\mathrm{P}-450$ in rat liver homogenate. Anal. Biochem. 75, 596-603. 
38 Omura T. and Sato R. (1964). The carbon-monoxide-binding pigment of liver microsomes; its hemoprotein nature. J. Biol. Chem. 239, $2370-2378$.

39 Grecnlice W.F. and Poland A. (1978). An improved assay of 7-ethoxycoumarin o-deethylase activity: induction in C57BL/6J and DBA/2J mice by phenobarbital, 3-methylcholanthrene and 2,3,7-chloro-dibenzo-p-dioxine. J. Pharmacol. Exp. Ther. 205, 596-605.

40 Lowry A.H., Rosebrough N.J. Farr A.L. and Randall R.J. (1951). Protein measurement with the follin fenol reagent. I. Bioll. Chern. 193, 265.

41 Yang C.S., Strickhart F.S. and Woo G.K. (1974). Inhibition of the mono-oxygenase system by butylated hydroxyanisolle and butylated hydroxytoluene. Life Sciences 15, 1497-1505.

42 Guarna A., Della Corte L., Giovannini M.G., de Sarlo F, and Sgaragli G. (1983). 2,2'-dihydroxy-3,3'di -1 -butyl-5,5'-dimethoxydiphenyl, a new metabolite of $2-t$-butyl-4-methoxyphenol in the rat. Drug Metab. Disp. 11, 581-584. 


\title{
Chapter 12
}

Dose-dependent effects of short-term dietary administration of the food additive butylated hydroxyanisole on cell kinetic parameters in rat gastro-intestinal tract

\author{
Hans Verhagen, Carina Furnée, Bert Schutte, Fré T. Bosman, Geert H. Blijham, \\ Peter Th. Henderson, Foppe ten Hoor and Jos C.S. Kleinjans \\ submitted for publication
}

\begin{abstract}
Groups of ten five-week old male Wistar rats were fed a diet containing 0 , $0.25,0.50,0.75,1.0$ or $2.0 \%$ butylated hydroxyanisole (BHA) ad libitum for 2 weeks; another group of rats served as a pair-fed control (PFC) group for the $2 \%$ BHA-fed animals. Subsequently, rats were injected i.p. with the thymidine-analogue bromodeoxyuridine (BrdU) which was incorporated into the DNA of dividing cells. Cell kinetic parameters in gastro-intestinal tract tissues were determined by means of bivariate BrdU/DNA analysis applying flow-cytometry to randomized tissue samples or by applying immunohistology to randomized tissue sections. In the forestomach, glandular stomach, small intestine an'd colon/rectum, mean tissue labelling index (LI) was significantly increased in rats on a diet supplemented with $2 \%$ BHA, in comparison with rats fed the basal diet $(0 \%$ BHA) ad libitum or restricted to the mean daily intake of $2 \%$ BHA-fed rats (PFC). In the oesophagus of rats fed $2 \%$ BHA, the LI was significantly higher in comparison with their PFC group, but not with the group of rats fed $0 \%$ BHA ad libitum. In rat forestomach, an apparent no-effect level for ad libitum fed rats was found at $0.5 \%$ BHA (LI) and at $0.75 \%$ BHA (potential doubling time). Thus, the oesophagus, glandular stomach, small intestine and large bowel, in addition to the forestomach, are possible target tissues in rats for the proliferation enhancing effects of BHA. At the time of termination of the experiment, plasma BHA concentrations were dosedependently increased and were in the range that is easily attained in man after ingestion of a dose equal to the acceptable daily intake for BHA (0.5 $\mathbf{m g} / \mathbf{k g}$ ).
\end{abstract}




\section{Int roduction}

The synthetic food antioxidant butylated hydroxyanisole (BHA) is carcinogenic in the forestomach of rodents $(1,2)$. Time- and dose-dependent changes in the forestomach epithelium include hyperplasia, papillomas and carcinomas $(3,4,5)$. In addition to these events, an increase in forestomach labelling index (LI) has been reported (6-11). Dogs, which do not possess a forestomach, are not affected by six months of oral BHA administration $(12,13)$ but in the oesophagus of pigs proliferative and parakeratotic changes were seen after sub-chronic dietary BHA feeding (14). In primates the mitotic index of the distal oesophagus was increased after 85 days of BHA administration (15). Apart from its carcinogenicity, BHA is a potent modulator of chemically induced mutagenesis and carcinogenesis, showing pro- as well as anti-genotoxic properties $(1,16-22)$.

In contrast to the well documented tumorigenic behaviour of BHA in rodents, little is known about the mechanism underlying its carcinogenicity. BHA is not mutagenic in the Salmonella/microsome assay $(17,22,23)$. Studies on its unknown carcinogenic mechanism may be facilitated by application of early markers of the tumorigenic potential of BHA. For BHA an increase in LI is regarded such an early marker. Using flow cytometry and immunocytochemistry, we recently confirmed an increase in forestomach $\mathrm{LI}$ and furthermore reported a decrease in potential doubling time (Tpot) in the forestomach of adult rats after 2 weeks on a diet containing $2 \%$ BHA. The mean transit time through the S-phase (Ts) was not altered; no significant effects were found in other gastro-intestinal tract tissues of rats (11).

We now report a detailed dose-response study on the effects of dietary BHA administration on cell kinetic parameters in the male rat forestomach, which was performed with the intention to establish a no-effect level (NEL). Since $2 \%$ BHA-fed rats largely diminished their caloric intake (11), which could interfere with the effects of BHA on cell kinetic parameters, a pair-fed control (PFC) group was included in addition to the $0 \% \mathrm{BHA}$ control group. In order to get a better insight into the possible risk of BHA consumption by man, other gastro-intestinal tract tissues (oesophagus, glandular stomach) have also been investigated by flow-cytometry. Furthermore, since our previously published flowcytometric methodology showed restricted applicability to several other tissues (glandular stomach, small intestine, colon/rectim), presumably resulting from a relatively high yield of non-dividing cells, the LI of these tissues has been determined by immunohistochemistry to detect incorporated BrdU.

Alterations in cell kinetic parameters are correlated with BHA concentrations in plasma measured at the end of the experiment. 


\section{Materials and methods}

A group of 70 five week old male Wistar rats (Winkelmann, Borchem, FRG), weighing $99 \pm 8 \mathrm{~g}$ (mean \pm SD) was randonly divided into sewen groups of ten animals. Rats were housed individually in metabolic cages in an air-conditioned environment at $22{ }^{\circ} \mathrm{C}, 50 \%$ humidity and a $12 \mathrm{~h}$ light/dark cycle. Until onset of the experiment the animals had free access to powdered regular lab chow (Hope Farms, Woerden, The Netherlands). Rats were given an experimental diet consisting of powdered lab chow supplemented with 0 (controls), $0.25,0.5,0.75,1$ or $2 \%$ BHA (food-grade BHA, purity $>99 \%, 93 \% 3-\mathrm{BHA}^{2}$ J. Dekker Company. Wormerveer, The Netherlands). A homogeneous mixture of BHA and lab chow was obtained using a food processor to crush the pellets, and a blender for thorough mixing.

All rats, except the PFC group, had free access to the food; tap water was available to all rats ad libitum. Food consumption was measured dailly and body weights were taken three times per weck. In order to compensate for possible effects of low caloric intake in the 2\% BHA group, a PFC group, given control diet restricted to the level of the mean daily intake of the rats in the $2 \%$ BHA group. was included for comparison.

On the $14^{\text {th }}$ day of the experiment, 4 hours preceding sacrificing, all rats received i.p. $1 \mathrm{ml}$ of $7.5 \mathrm{mg} / \mathrm{ml}$ bromodeoxyuridine (BrdU; Serva, Heidelberg, FRG) dissolved in phosphate-buffered saline (PBS). The rats were killed under ether anaesthesia by exsanguination. For the determination of plasma BHA concentrations, plasma was prepared from the heparinized blood by centrifugation for $10 \mathrm{~min}$ at $2000 \mathrm{~g}$ and stored at $-20^{\circ} \mathrm{C}$ until analysis. The gastro-intestinal tract (oesophagus, forestomach, glandular stomach, small intestines and colon/rectum) was dissected, opened lengthwise, cleaned from its contents, washed, fixed in $70 \%$ ethanol and stored at $4{ }^{\circ} \mathrm{C}$ in the dark.

Preparation of the oesophagus, forestomach and glandular stomach for flow cytometric determination of the LI, Tpot and Ts was performed according to the procedure described by Schutte et al. (24) and Verhagen et al. (11). LI, Tpot and Ts were calculated as described by Begg et al. (25). In short, four samples per tissue per rat were randomly taken from the ethanol-fixed tissues, cut into tiny pieces and treated with $0.4 \mathrm{mg} / \mathrm{ml}$ pepsin in $0.1 \mathrm{~N} \mathrm{HCl}$ at room temperature for $60 \mathrm{~min}$ under gentle agitation. Released nuclei were collected by filtration through a nylon $50 \mu \mathrm{m}$ gauze and subsequently treated with $2 \mathrm{~N} \mathrm{HCl}$ for $30 \mathrm{~min}$ at $37^{\circ} \mathrm{C}$ for DNA denaturation. Subsequently, nuclei were exposed to monoclonal anti-BrdU antibody (clone II B5) for 60 min at room temperature. BrdU-containing cells were visualized by means of a 60 min incubation at $4{ }^{\circ} \mathrm{C}$ with fluorescein-conjugated rabbit anti-mouse IgG-FITC (F313, Dakopatts, Denmark). Total DNA was stained with propidium iodide (Calbiochem, Behring Diagnostics, San Diego, CA). Flow-cytometry on these double-stained cells was performed as previously described (11). The LI is expressed as the percentage of BrdU-positively stained cells. By this method, no distinction can be made between epithelial and nonepithelial cell types. The detection limit for the LI is $-0.5 \%$.

In a previous experiment, tissue from the small intestime, large bowell and glandular stomach could not be analyzed by flow-cytometry to our consent (11). Therefore, random samples from these lissues were embedded in paraffin according to routine histological procedures for immunohistochemical determination of the LI. An indirect enzyme-labelled antibody technique with peroxidase-conjugated second step reagents as described by Schutte et al. (26), was used to detect BrdU-contsining cells in tissue sections. In short, sections were mounted on glass slides, cleared of paraffin and treated with $0.3 \% \mathrm{H}_{2} \mathrm{O}_{2}$ in methanol for $10 \mathrm{~min}$ to block endogenous peroxidases. Pepsin digestion and denaturation of DNA was essentially the same as described for flow cytonetry. Instead of using rabbit anti-mouse IgG-FITC, tissue sections were finally incubated with peroxidase-conjugated rabbit anui-mouse IgG (F114, Dakopatts, Denmark) for one hour at room temperature. The antibody binding sites were visualized by submerging the slides in $0.04 \%$ diaminobenzidine in $0.05 \mathrm{M}$ Tris/HCl buffer $\mathrm{pH} 7.6$ containing $0.01 \% \mathrm{H}_{2} \mathrm{O}_{2}$. Finally, sections were counterstained with haematoxylin. Slides were blinded, encoded and epithelial cells were scored in duplicate for immunoreactivity by two independent obserwers. The code was not broken until all counting was finished. The LI in the glandular stomach was calculated as the percentage of BrdU-labelled cells per unit of surface area. In the small and large intestines the number of BrdU-labelled cells was calculated as fraction of the total number of crypt cells. The $\mathrm{LI}$ is expressed as the percentage of positively stained cells. On average 1500,2000 and 4000 cells were scored in the colon/rectum, small intestines and glandular stomach, respectively. Since there was a good correspondence between the values scored by the two observers - interobserver variation was $10 \pm 10 \%$ (mean $\pm S D$ )- - values of the two observers are averaged.

Plasma BHA concentrations were determined as previously described (27).

Student t-test for unpaired walues was used to assess statistical significance of differences between 
experimiental and appropriate control groups; $\mathrm{p}<0.05$ is considered significant.

\section{Results}

Mean food consumption and mean body weights are displayed in figures 12-1 and 12-2, respectively. In ad libitum fed rats, there was a gradual decrease in food consumption in the highest dosage groups which gained statistical significance at $0.75 \%$ BHA. Thus the maximum tolerated dose in this experiment was $0.50 \% \mathrm{BHA}$ in the diet. A strong correlation was found between the average food intake and the increase in body weight over the experimental period $(\mathrm{r}=0.93 ; \mathrm{p}<0.001)$. At termination of the experiment, significantly lower body weights were recorded for rats in the $1 \%$ BHA $(178 \pm 17 \mathrm{~g} ; \mathrm{p}<0.05), 2 \% \mathrm{BHA}$ $(146 \pm 18 ; \mathrm{p}<0.001)$ and PFC groups $(155 \pm 6 \mathrm{~g} ; \mathrm{p}<0.001)$ vs. rats on a control diet fed $a d$ libitum $(193 \pm 13 \mathrm{~g})$. No difference in body weight between $2 \%$ BHA fed rats and their appropriate PFC group was observed. One animal in the $2 \%$ BHA group died on day 7 of the experiment.

The LI and Tpot in randomly taken samples of forestomach tissue as measured by flow cytometry are presented in Figure 12-3. There appeared to be a dose-dependent increase and decrease in LI and Tpot, respectively. Apparent NEL's in these ad libitum fed rats were observed at $0.5 \%$ (LD) and $0.75 \%$ (Tpot) B.HA in the diet. The effect of feeding $2 \%$ BHA was even more pronounced in comparison with its PFC group. The $\mathrm{LI}$ (resp. Tpot) in the forestomach of PFC rats was significantly lower (resp. higher) as compared to rats fed the same basal diet ad libitum.

At termination of the experiment, BHA concentrations in plasma were dose-dependently increased in rats fed $0.25-2.0 \%$ BHA, and generally were in the range of 0 to $100 \mathrm{ng} / \mathrm{ml}$ (Figure 12-4). Individual plasma BHA concentrations correlated significantly with individual forestomach $\mathrm{LI}(\mathrm{r}=0.47 ; \mathrm{p}<0.001)$, calculated for all rats fed a BHA-containing diet.

In the oesophagus, the LI was not increased in the group of rats fed $2 \%$ BHA in comparison with the group of rats fed 0\% BHA ad libitum (Table 12-1). Actually, the LI and Tpot were significantly lower resp. longer $(p<0.05)$. However, in comparison with the PFC group, a proliferation enhancing effect of feeding $2 \%$ BHA on oesophageal tissue was evident in these rats, as the LI was increased and the Tpot was decreased. As in the forestomach, the LI (and Tpot) were significantly decreased (and increased) in PFC rats vs. rats on a control diet available ad libitum.

Also in other parts of the gastro-intestinal tract (i.c. glandular stomach, small intestine, colon/rectum) a response of cell kinetic parameters was found after the administration of $2 \%$ BHA in the diet, as was evident from an increase in LL. Only in the glandular stomach, this effect of BHA did not gain statistical significance in comparison with the PFC group, when assessed by immunohístochemical staining of tissue sections. Besides an increase in LI no pathological effects of feeding $2 \%$ BHA were found in tissue sections from glandular stomach, small intestines or colon/rectum. No difference in tissue LI of the glandular stomach, small intestine, colon/rectum was observed between the 2 control groups of rats fed a BHA-free basal diet either ad libinum or restricted. Results are summarized in Table $12-\mathrm{I}$.

Within the group of rats fed $2 \% \mathrm{BHA}$, there was no correlation between cell kinetic data in the examined gastro-intestinal tract tissues. 


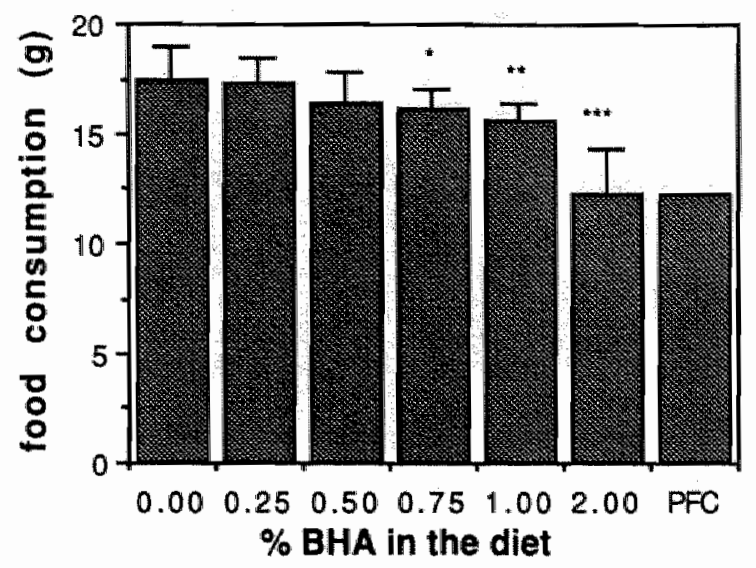

Figure 12-1: Mean food consumption of male Wistar rats fed a diet comtaining different amosuts of BHA for 2 weeks. Asterisks indicate statistical significant differences vs the control ( $0 \%$ BHA) group at $p<0.05\left(^{*}\right)$. $p<0.011^{* *}$ ) and $p<0.001\left(^{* * *}\right)$. PFC indicates a group of rats given the mean daily food intake of the $2 \%$ BHA-fed rats. Mean $\pm S D$.

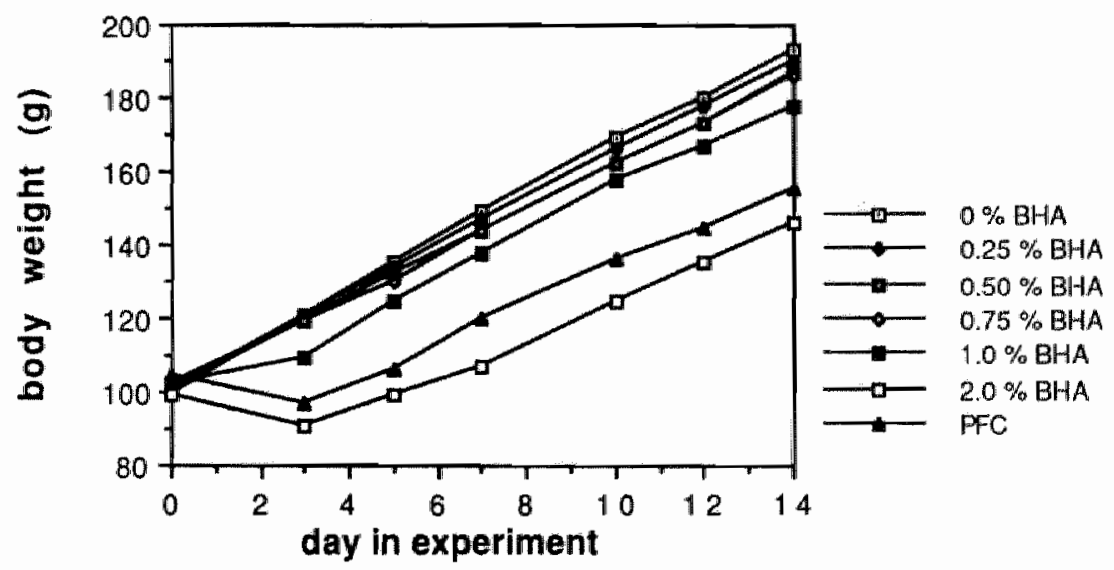

Figure 12-2: Mean body weights of rats fed a control dier $(0 \%$ BHA, PFC) ar a diet containing different amounts of BHA for 14 days. Body weights of rats fed I and $2 \%$ BHA were significanly lower as compared to control (O\% BHA) rats. Statistically there was no significant difference between the $2 \%$ BHA-fed rats and their PFC group. 


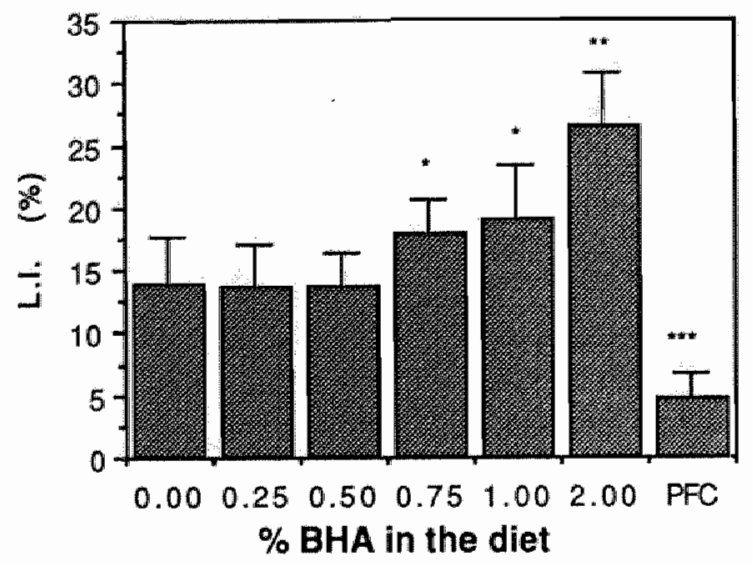

Figure 12-3a: LI's in forestomach vissue of rats fed $0-2 \%$ BHA ad libitum for 2 weeks. $P F C$ rars received a limited amount of BHA-free lab chow. LI's were determinted using flow cylometry. Asterisks indicate significant differences from the control (0\% BHA) group at $p<0.02\left({ }^{*}\right)$ and $p<0.0011^{* *}$ ). LI's in the PFC group were significantly different from the $L I " s$ in the $0 \%$ and $2 \%$ BHA-fed growps at $p<0.001$ (स).

Mean $\pm S D$.

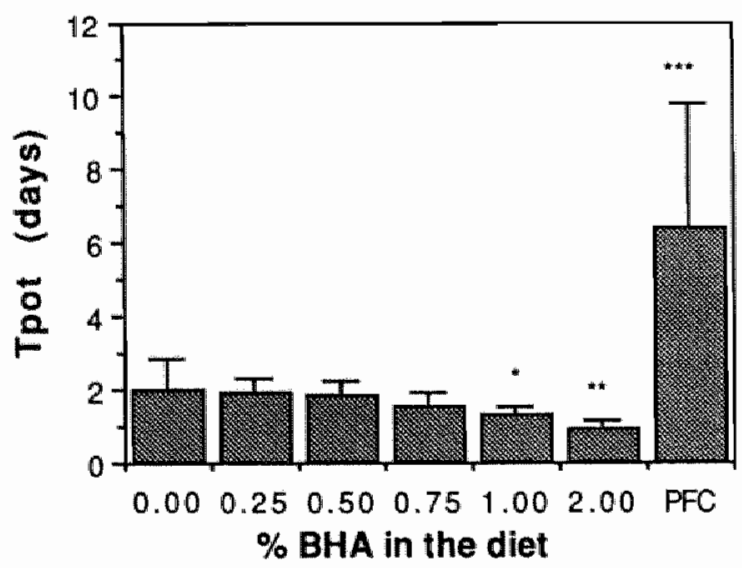

Figure 12-3b: The Tpot in forestomuch tissue of rats fed $0-2 \%$ BHA ad libisum for 14 days. PFC rats were affered a restricted amount of the control diet. The Tpot was determined by flow cytometry. *: significantly different from the $0 \%$ BHA group at $p<0.02 ;{ }^{* *}$ : significantly different from the $0 \%$ BHA group at $p<0.002$ and at $p<0.001$ from the PFC group; : significantly higher as compared to 0 and $2 \%$ BHA-fed groups $(p<0.001)$. Mean $\pm S D$. 
dose-dependent effects of BHA in rat CI tract

TABLE 12-I. CELL KINETIC PARAMETERS IN OESOPHAGUS, GLANDULAR STOMACH, SMALL INTESTINE AND COLON/RECTUM.

\begin{tabular}{|c|c|c|c|c|}
\hline Tissue & parameter & $0 \%$ BHA group & 2\% BHA group & PFC group \\
\hline \multirow[t]{2}{*}{ oesophagus. } & $\mathbf{L}_{f c}(\%)$ & $11.1 \pm 2.4$ & $9.0 \pm 1.5^{a}$ & $2.1 \pm 1.1^{b}$ \\
\hline & Tpot (days) & $2.2 \pm 0.5$ & $2,9 \pm 0.6^{a}$ & $13.1 \pm 5.8^{b}$ \\
\hline \multirow[t]{3}{*}{ glandular stomach } & $\mathrm{LI}_{f c}(\%)$ & $2.7 \pm 0.4$ & $4.2+1.1^{\mathrm{C}}$ & $2.5 \pm 0.4$ \\
\hline & Tpot (days) & $4.3 \pm 0.8$ & $2.9 \pm 0.5^{c}$ & $5.1 \pm 0.9$ \\
\hline & $\mathrm{LI}_{i h}(\%)$ & $2.7 \pm 0.8$ & $6.1 \pm 3.4^{d}$ & $3.4 \pm 1.1$ \\
\hline small intestine & $\mathrm{LI}_{i h}(\%)$ & $19.2 \pm 3.3$ & $26.4 \pm 2.9^{\mathrm{e}}$ & $15.4 \pm 4.4$ \\
\hline colon/rectum & $\mathrm{LI}_{i h}(\%)$ & $9.9 \pm 2.6$ & $23.1 \pm 6.4^{\mathrm{e}}$ & $8.8 \pm 1.8$ \\
\hline
\end{tabular}

The LI was determined by flow-cytometry $(f c$ ) or by immunohistology (ih); the Tpot was determined by flow cytometry. Superscripts indicate the statistical significance of differences. a: $\mathrm{P}<0.05$ vs $0 \%$ BHA group; b: $\mathrm{P}<0.001$ vs $0 \%$ BHA and $2 \%$ BHA group; $\mathrm{c}$ : $\mathrm{P}<0.01$ ws $0 \%$ BHA and PFC group; $\mathrm{d}$ : $<<0.01$ vs $0 \%$ BHA group; e: $\mathrm{P}<0.001$ vs 0\% BHA and PFC group. Mean $\pm S D$.

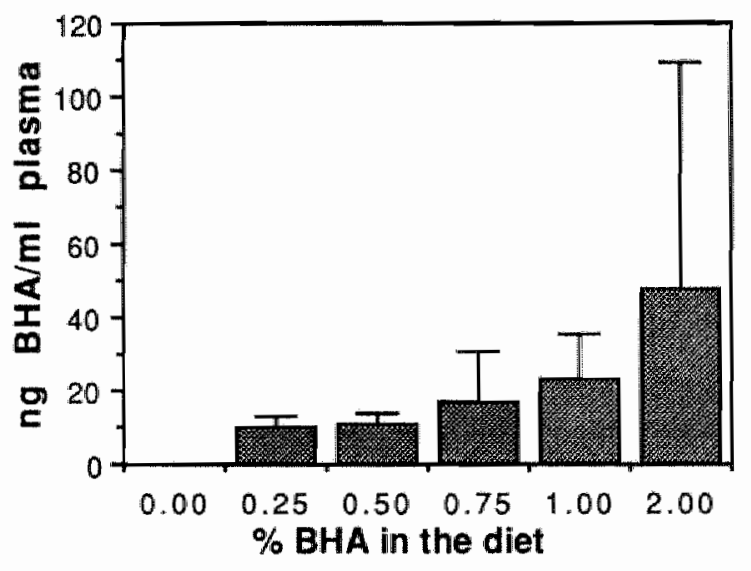

Figure 12-4: BHA concentrations in plasma at termination of the experiment. Limit of detection was 10 $n g / m l . M e a n \pm S D$. 


\section{Discussion}

BHA is a potent modulator of chemically induced carcinogenesis in gastro-intestinal tract tissues, but also in other organs like liver, bladder and lungs $(1,16-22)$. Furthermore, target organs for proliferation enhancing effects of BHA per se are the forestomach in rodents (rats, hamsters and mice)(1-11), and possibly the oesophagus in non-rodents like pigs and monkeys $(14,15)$. To our knowledge, BHA has not been reported to increase cell proliferation in other parts of the digestive tract in rodents or non-rodents.

Since there appeared to be no significant difference in body weight between rats on a diet containing $2 \% \mathrm{BHA}$ and their PFC group, it is concluded that a decreased body weight gain in rats fed $2 \%$ BHA is merely due to a diminished food intake, as a consequence of the nonpalatability of the experimental diet. Because a diminished caloric intake leads to a decrease in tumor development (28), an effect of reduced daily caloric intake cannot be ruled out, when performing carcinogenicity-related studies with levels of BHA in the diet which exceed the maximum tolerated dose (0.50\% BHA).

Results from this study indicate that all examined tissues from the gastro-intestinal tract of rats (i.e. oesophagus, forestomach. glandular stomach, small intestine and colon/rectum) are susceptible to the proliferation enhancing potential of BHA. It is emphasized that the parameters measured in this study (LI and Tpot) may be regarded as early markers of the carcinogenic potential of BHA. Within this respect a positive correlation between an elevation in tissue $\mathrm{LI}$ and the possibility of tumor development in the colon/rectum of laboratory animals and man has been reported $(29,30)$.

The proliferation enhancing effects of BHA after 14 days administration of $2 \%$ in the diet of rats are statistically significant in all examined tissues, except for the oesophagus, in comparison with either a PFC group or a group of animals fed the basal diet ad libitum. Therefore, possible methodological bias, introduced by feeding a restricted amount of control diet to a particular group of animals, may be excluded.

By application of flow cytometry/immunocytochemistry we found a NEL of $0.50 \%$ and $0.75 \%$ BHA in rat forestomach with respect to the $\mathrm{LI}$ and Tpot, respectively. NEL's for the proliferative effects of BHA in rodent forestomach have been reported to be $0.125 \%$ BHA (lesions; 31), 0.25\% BHA (LI; 8,10) and 0.5-1.0\% BHA (tumor development; 3,32,33), which is in agreement with our results. Because a diminished caloric intake has considerable effects on both the LI and Tpot in rat forestomach, the NEL assessed for BHA-induced alterations in this tissue should be referred to as "a NEL in ad libitum fed rats". It cannot be excluded that the NEL for the effects of BHA on cell kinetic parameters in this tissue differs slightly from the values reported above, when each experimental dose group of rats would have been compared with its own PFC group. Only Altmann et al. $(5,31)$ used PFC rats in order to compensate for effects of low caloric intake, but determined only histological changes in rat forestomach. The well-known proliferation inducing effects of BHA in rat forestomach tissue are even more pronounced when the effect of food reduction on cell kinetic parameters is taken into consideration.

In studies in which a proliferative effect on the forestomach of rats has been reported after administration of BHA in the diet, the oesophagus has seldom been analyzed and no differences in LI or histopathology in comparison with ad libitum fed controls have been observed $(19,33)$. However, our results indicate that 14 day administration of $2 \% \mathrm{BHA}$ in the diet significantly increases the LI and decreases the Tpot in rat oesophagus as compared to the PFC group. An effect of BHA in this rodent target tissue may previously not have been noticed, as values for the LI and Tpot in the $2 \%$ BHA-fed group are approximately 
equal to the values measured in rats fed 0\% BHA ad libitum. We did not study rat oesophagus other than for cell kinetic parameters.

Other studies reporting on proliferation enhancing effects of BHA in the forestomach of rodents, did not demonstrate similar changes in glandular stomach, a possible target organ in close proximity to the affected forestomach $(1,8,17,31,32)$. This study, however, indicates that also the glandular stomach is a target tissue for BHA. By flow-cytometrical and immunohistochemical techniques it was shown that the LI (and Tpot) in random glandular stomach tissue samples changed subsequent to feeding rats $2 \%$ BHA in the diet. Differences were statistically significant in comparison with both the 0\% BHA as well as the PFC group, although the differences between the 2\% BHA and its PFC group did not gain statistical significance when examined immunohistologically. Earlier reports on effects of BHA, applying different methods of analysis, did not mention histological changes in the glandular stomach, which we confirm, nor did they mention increases in LI of glandular stomach tissue, which we contradict. The increase in $\mathrm{LI}$ and decrease in Tpot measured in this particular experiment may be explained by the application of methodologies different from those used by other investigators. However, the fact that the increase in glandular stomach LI has been verified by two methods, flow cytometry and immunohistology, constitutes a clear indication of the proliferation inducing potential of BHA in this target tissue.

To our knowledge, also small intestine and large bowel tissue have not previously been reported to be susceptible to the proliferation enhancing effects of BHA. Several tumors have been found in small and large intestines of rats after 2 year feeding of BHA at a dietary level of 0.5 and $2.0 \%$, but increases in tumor incidence were not statistically significant (2). In a preceding study, applying flow cytometry, no statistically significant effects on cell kinetic parameters in ileum, caecum and colon tissue were observed but the reported LI's $(0.5-2.5 \%)$ were close to the detection limit for this methodology $(\sim 0.5 \%)(11)$. In contrast, the $\mathrm{LI}$ in these tissues has been reported to be much higher than 0.5 to $2.5 \%$ using histological methods for analysis (34). The rather low Ll of intestinal tissues measured by flow cytometry probably results from a high yield of non-dividing cells (e.g. stroma cells) in the sample preparation procedure thus causing a dilution of BrdU-positive cells. It was concluded that the flow-cytometric method might not be applicable to intestinal tissues. Therefore, immunohistology using monoclonal anti-BrdU antibodies was used to determine the $L I$ in these organs. Agaiin, data indicate a proliferation stimulating effect of 14 days of dietary administration of $2 \%$ BHA, which was evident in the small intestine and the colon/rectum, as compared to the 0\% BHA control as well as to the PFC group.

These results indicate that not only the forestomach is a target tissue for proliferation enhancing effects of BHA, but that other digestive tract tissues (oesophagus, glandular stomach, small intestine and colon/rectum) are also affected by BHA. Consequently, not only squamous epithelial cells are susceptible to the proliferation stimulating effects of BHA, but other cell types lining the lumen of the gastro-intestinal tract as well. In the future, studies have to be performed focusing on the unknown mechanism underlying the induction of proliferation enhancing changes and tumorigenicity by BHA in all target tissues. There is no evidence for a causal relationship between cell proliferation and tumor development in the forestomach of rats in response to dietary BHA administration. However, a close relationship between strong proliferation enhancing stimuli and ultimate tumor development is not unlikely $(35,36)$. Following the multistage-model for carcinogenesis, initiation is a prerequisite, introducing a genotypical alteration in the DNA, possibly at the level of specific 
(onco)genes (37). Although BHA generally gives negative results in short-term tests for genetic activity $(17,22,23)$, tumor initiating potential of $\mathrm{BHA}$ has been reported in the twostage mouse skin carcinogenesis system (38) and in the forestomach of rats following partial hepatectomy as a growth promoting factor $(39)$. In addition, data by Masui et al. $(40,41)$ provide further support for the view that BHA induces genotypical changes in DNA: BHAinduces downward basal cell proliferation and basal cell hyperplasia of squamous epithelial cells in the forestomach that were persistent for up to 72 weeks after withdrawal of BHA from the diet of rats. In their studies one forestomach carcinoma was reported 24 weeks after withdrawal of BHA. Therefore, future experiments on the induction of proliferation enhancing and carcinogenic changes in rodent gastro-intestinal tract tissues should focus on DNA-damaging potential of BHA. BHA does not bind covalently to forestomach DNA (42), which suggests that it affects DNA in an indirect way. Therefore, other endpoints of genotoxicity should be subjected to investigation (e.g. aberrant DNA methylation, modulation of DNA by reactive oxygen species, unscheduled DNA synthesis, aberrant [onco]gene expression) $(43,44,45,46,47)$.

Plasma leveis are supposed to be an indication of concentrations of an agent at other tissues, possibly effective concentrations at a target tissue site. It should be noted that plasma BHA concentrations at the time of termination of the experiment are in the order of 0 to $100 \mathrm{ng} / \mathrm{ml}$ after doses of $0.25-2.0 \%$ BHA in the diet, and that these levels are easily attained in man following oral ingestion of the acceptable daily intake for BHA $(0.5 \mathrm{mg} / \mathrm{kg})(48)$. However, it cannot be excluded that growth-stimulating effects of BHA in the gastro-intestinal tract, as monitored by an increase in $\mathrm{LI}$, in fact represent proliferative responses to directly cytotoxic actions of BHA rather than carcinogenic events. In this respect plasma BHA levels might be of minor importance.

In conclusion, the results of this study suggest that in rats several gastro-intestinal tract tissues possess target cells for the proliferation enhancing effects of BHA. Because it cannot be excluded that human gastro-intestinal tract tissues may be affected by BHA via a similar mode of action, application of this additive in foodstuffs should be handled carefully.

\section{Acknowledgements}

The authors appreciate the helpful discussions with Mr. A. de Bruine and the excellent technicall assistance of Mrs. M. Reynders.

\section{References}

1 Ito N., Fukushima S. and Tsuda H. (1986). Carcinogenicity and modification of the carcinogenic response by BHA, BHT and other antioxidants. CRC Crit. Rev. Toxical. 15, 109-150.

2. Ito N., Fukushima S., Hagiwara A., Shibata M. and Ogiso T. (1983). Carcinogenicity of butylated hydroxyanisole in F344 rats. J. Natl. Cancer Inst. 70, 343-352.

3 Ito N., Fukushima S., Tamano S., Hirose M., and Hagiwara A. (1986). Dose response in butylated hydroxyanisole induction of forestomach carcinogenesis in F344 rats. J.Natl.Cancer Inst. 77, 12611265.

4 Masui T., Hirose M., Imaida K., Fukushima S., Tamano S. and Ito N. (1986). Sequential changes in the forestomach of F344 rats, Syrian golden hamsters and B6C3F1 mice treated with butylated hydroxyanisole. Gann $77,1083-1090$. 


\section{dose-dependent effects of BHA in rat GI tract}

5 Altmam H.-J., Wester P.W., Matthiaschk G.G., Grunow W, and Van der Heijden C.A. (1985). Induction of early lesions in the forestomach of rats by 3-tert-butyl-4-hydroxyanisole (BHA). Food Chem. Toxicol. 23, 723-731.

6 Iwerson $F_{*}$ Lok E., Nera E., Karpinski K. and Clayson D.B. (1985). A 13-wcek feeding study of butylated hydroxyanisole: the subsequent regression of the induced lesions in malle Fischer 344 rat forestomach epithelium. Toxicology 35, 1-11.

7 Rodrigues C., Lok E., Nera E., Iverson F. Page D. Karpinski K. and Clayson D.B. (1986). Short term effects of various phenols and acids on the Fischer 344 male rat forestomach epithelium. Toxicology 38 , 103-117.

8 Clayson D.B., Iverson F. Nera E., Lok E., Rogers C., Rodrigues C., Page D. andKarpinski K. (1986). Histopathological and radioautographical studies on theforestomach of F344 rats treated wilh butylated hydroxyanisole and related chemicals. Food Chem. Toxicol, 24, 1171-1182.

9 Hirose M., Inoue T., Asamoto M., Tagawa Y. and Ito N. (1986). Comparison of the effects of 13 phenolic compounds in induction of proliferative lesions of the forestomach and increase in the labelling indices of the glandular stomach and urinary bladder epithelium of Syrian golden hamsters. Carcinogenesis 7, 1285-1289.

10 Nera E.A., Lok E., Iverson F., Ormsky E., Karpinski K.F. and Clayson D.B. (1984). Short-term pathological and proliferative effects of butylated hydroxyanisole and other phenolic antioxidants in the forestomach of Fischer 344 rats. Toxicology 32, 197-213.

11. Verhagen H., Schutte B., Reynders M.M.J., Blijham G.H., ten Hoor F. and Kleinjans J.C.S. (1988). Effect of short-term dietary administration of butylated hydroxyanisole on cell kinetic parameters in rat gastro-intestinal tract, assessed by immunocytochemistry and flow cytometry, Carcinogenesis 9, 11071109.

12 Tobe M., Furuya T., Kawasaki Y., Naito K., Sehita K., Matsumoto K., Ochiai T., Usui A., Kokubo T., Kanno J. and Hayashi $Y$. (1986). Six-month toxicity sudy of butylated hydroxyanisole in beagle dogs. Food Chem, Toxicol, 24, 1223-1228.

13. Ikeda G.J., Stewart J.E.* Sapienza P.P., Peggins III J.O., Michel T.C., Olivito V., Alam H.Z. and ODonell Jr. M.W. (1986). Effect of subchronic dietary administration of butylated hydroxyanisole on canine stomach and hepatic tissue. Food Chem. Toxicol. 24, 1201-1221.

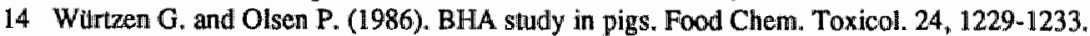

15 Iverson F., Truelove J., Nera E., Wong J., Lok E. and Clayson D.B. (1985). An 85-day study of butylated hydroxyanisole in the cynomolgus monkey. Cancer Lett. 26,43-50.

16 Anonymous (1984). Final report on the safety assessment of butylated hydroxyanisole.

J. Amer. Coll. Toxicol. 3, 83-146.

17. Anonymous (1986). Butylated hydroxyanisole (BHA). IARC Monographs on the evaluation of the carcinogenic risk of chemicals to humans. 40, 123-159.

18. Hocman $G$. (1988). Chemoprevention of cancer: phenolic antioxidants (BHT, BHA). Int. J. Blochem. 7, 639-651.

19 Fukushima S., Sakata T., Tagawa Y., Shibata M.-A A, Hirose M. and Ito N. (1987). Different modifying response of butylated hydroxyanisole, bulylated hydroxytoluene, and other antioxidants in $\mathbb{N}_{n} N_{\text {. }}$ dibutylnitrosamine esophagus and forestomach carcinogenesis of rats. Cancer Res. 47, 2113-2116.

20. Kitchin K.T. and Brown J.L. (1987). Biochemical effects of two promotors of hepatocarcinogenesis in rats. Food Chem. Toxicol. 25, 603-607.

21. Wattenberg L.W. (1985). Chemoprevention of eancer. Cancer Res. 45, 1-8.

22. Kahl R. (1986). The dual role of antioxidants in the modification of chemical carcinogenesis. $J$. Environ. Sc. Health C4(1), 47-92.

23. Hageman G.J., Verhagen H. and Kleunjans J.C.S. (1988). Butylated hydroxyanisole, butylated hydroxytoluene and ter-butylhydroquinone are not mutagenic in the Salmonella/microsome assay using new tester strains. Mut. Res. 208, 207.211.

24. Schutte B., Reynders M.M.J., Van Assche C.L.M.V.J., Hupperets P.S.G.J., Bosman F.T and Blijham G.H. (1987). An improved method for the immunocytochemical detection of BrdU labelled nuclei using flow cytometry. Cytometry 8, 372-376.

25. Begg A.C., McNally N.J., Shrieve D.C. and Karcher H. (1985). A method to measure the duration of DNA synthesis and the potential doubling time from a single sample. Cytometry 6,620-626.

26. Schute B., Reynders M.M.J., Bosman F.T. and Blijham G.H. (1987). The effect of tissue fixation on anti-bromodeoxyuridine immunohistochemistry. J. Histochem. Cytochern. 35, 1343-1345. 
27. Verhagen H. Twijssen H.H.W. and Kleinjans J.C.S. (1987). Sensilive high-performance liquid chrofinatographic method for the routine detemination of butylated hydroxyanisole in plasma. $J$. Chromatogr $413,282-286$.

28. Albanes $\mathrm{D},(1987)$. Calonic intake, body weight, and cancer, a review. Nutrition and Cancer 9, 199-217

29. Richards T.C. (1977). Early chages in the dynamics of crypt cell populations in mouse colon following administration of 1.2 dimethylhydrazine, Cancer Res. $37,1680-1685$.

30. Kancmitsu T. Koilke A. and Yamamoto $S_{\text {. }}$ (1985). Sudy of the cell proliferation kinetics in ulcerative colitis, adenomatous polyps, and cancer. Cancer 56, 1094-1098.

31. Almann H.J., Grinow W. Mohr U. "Richter-Reichhelm H.B. and Wester P.W. (1986). Effects of BHA and related phenols on the forestomach of rats, Food Chem. Toxicol. 24, 1183-1188.

32. $110 \mathrm{~N}$, and Hirose $\mathrm{M}_{\text {. }}(1987$ ). The role of antioxidants in chemical carcinogenesis, Gann 78, $1011-1026$.

33. Grice H.C. Safety ewaluation of bulylated hydroxyanisole from the perspectiwe of effects on forestomach and esophageall squamous epithelium. Food Chem. Toxicol. (in press).

34. Schutte B., Reynders M.M.J., Bosman F.T. and Blijham G.H. (1987). Studies with antibromodeoxyuridine antibodies. II. Simulianeous immunochemical detection of antigen expression and DNA synthesis by in vivo labelling of mouse intestinal mucosa. J. Histochem. Cytochem. 35, 371374.

35. Kroes R. and Wester P.W. (1986). Forestomach carcinogens: possible mechanisms of action. Food Chem. Toxicol. 24, 1083-1089.

36. Ghanayem B.I., Maronpot R.R. and Mathews H.B. (1986). Association of chemically induced forestomach cell proliferation and carcinogenesis. Cancer Lett. 32, $271-278$.

37. Hermo H. Jr. and Brandt-Rauf P.W. (1987). Chemically induced oncogenesis. Sem. Occup. Med. 2, $235-243$

38. Salo H., Takahashi F Furukawa F. Miyakawa Y., Hasegawa R., Toyoda K. and Hayashi Y. (1987). Initiating potential of 2-(2-furyl)-3-(5-nitro-2-furylacrylamide (AF-2), butylated hydroxyanisole (BHA), butylated hydroxytoluene (BHT) and $3,3,4,5,7$-pentahydroxyflavone (quercetin) in two-stage mouse skin carcinogenesis. Cancer Lett. 38, 49-56.

39. Abraham R., Benitz K.F., Patil G. and Lyon R. (1986). Rapid induction of forestomach tumors un partially hepatectomized Wistar rats given butylated thydroxyanisole. Exp. Molec. Pathol. 44, 14-20.

40. Masui T., Asamoto M., Hirose M., Fukushima S. and Iti N. (1986). Disappearance of upward proliferation and persistence of dowmward basal cell proliferation in rat forestomacth papillomas induced by butylated hydroxyanisole. Gann $77,854-857$.

41. Masui T., Asamoto M., Hirose M. Fukushima S. and Iti N. (1987). Regression of simple hyperplasia and papillomas and persistence of basal cell hyperplasia in the forestomach of F344 rats treated with butylated hydroxyanisole. Cancer. Res. 47, 5171-5174.

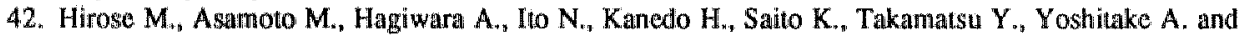
Miyamoto J. (1987). Metabolism of 2-and 3-tert-butyl-4-hydroxyanisole (2-and 3-BHA) in the rat (II): motabolism in forestomach and cowalent binding to tissue macromolecules. Toxicology 45, 13-24.

43. Ventit $S_{*}$ Bartsch H., Becking G., Fuchs R.P.P., Hofnung M., Malaveille C. Matsushima T., Pegg A.E., Rajewsky M.R. Roberfroid M. Rosenkranz H.S. and Williams G.M. (1986). DNA damage and repair in: Long-term and short-term assays for carcinogens: a critical appraisal. (R. Montesano, $H$. Bartsch, $\mathrm{H}_{4}$ Vaino, J. Wilbourn and $\mathrm{H}_{n}$ Yamasaki, Eds.), IARC Scientific Publications No. 83, p129142.

44. Shank R.C. and Barrows L.R. (1985). Toxicological effects on carcinogenesis. in: Toxicological risk assessment. Biological and statistical criteria. (D.B. Clayson, D. Krewski and I. Murro, Eds.), voll I, CRC Press, Boca Raton; FL, USA, p91-104.

45. Molzer P., Kinzler K., Vogelstein B. and Trent J.M. (1986). Gene amplification in camcer: a molecular cytogenetic approach. Cancer Gemet. Cytogenet. 19,93-99.

46. Grice H.C. Clayson D.B., Filamm W.G., Ito N., Kroes R., Newberne P.M. and Scheuplein R. (1986). Possible mechanisms of BHA carcinogenicity from a consideration of its chemical and biological properties. Food Chem. Toxicol. 24, 1235-1242.

47. Rosier $J_{3} A_{\text {. }}$ and van Peteghen $C H$. (1989). Peroxidative in vitro metabolism of diethylstilbestrol induces formation of 8-hydroxy-2"-deoxyguanosine. Carcinogenesis $10,405-406$.

48. Verhagen H., Thijssen H.H.W., ten Hoor F. and Kleinjans J.C.S. (1989) Disposition of single oral doses of butylated hydroxyanisole in man and rat. Food Chem. Toxicol. 27, 151-158. 
PART V

DAILY DIETARY INTAKE OF BHA AND BHT BY MAN 



\title{
Chapter 13
}

\section{Estimate of the maximal daily dietary intake of butylated hydroxyanisole and butylated hydroxytoluene in The Netherlands}

\author{
Hans Verhagen, Ingeborg Deerenberg, Anita Marx, Foppe ten Hoor, \\ Peter Th. Henderson and Jos C.S. Kleinjans \\ submitted for publication
}

\begin{abstract}
The daily dietary intake of the phenolic antioxidants butylated hydroxyanisole (BHA) and/or butylated hydroxytoluene (BHT) is estimated using data obtained via a nationwide dietary record survey held in The Netherlands in 1987/1988. Estimates are based on the fat content of seven out of twenty-three selected food categories and their respective maximal permitted levels of BHA and/or BHT.

Results indicate that it is unlikely that the current acceptable daily intake (ADI) for BHA $(0-0.5 \mathrm{mg} / \mathrm{kg})$ is surpassed, even in individuals with an extremely high caloric intake. In contrast, it cannot be excluded that the ADI for BHT (FAO/WHO: $0-0.125 \mathrm{mg} / \mathrm{kg}$; EEC: $0-0.05 \mathrm{mg} / \mathrm{kg}$ ) is exceeded in all age and sex groups, but particularly in younger children of 1-6 years old.
\end{abstract}

\section{Introduction}

Butylated hydroxyanisole (BHA; E320; CAS nr: 25013-16-5) and butylated hydroxytoluene (BHT; E321; CAS nr: 128-37-0) are synthetic phenolic antioxidants used widely to prevent oils, fats and shortenings from oxidative deterioration and rancidity (Sims and Fioriti, 1980). These compounds are substances which are Generally Recognized As Safe (GRAS), as a result of their relatively low toxicity. In addition, chemopreventive activity in relation to carcinogenesis has been ascribed to BHA and BHT (Wattenberg, 1985; Hocman, 1988). Recently however, major concern has risen with regard to their application as food additives. BHT as well as BHA have proven to be potent enhancers of mutagenesis and carcinogenesis induced by chemicals (Anonymous, 1984, 1986 a $1986^{\mathrm{b}}$; Ito et al., 1985 , 1988; Kahl 1986; Kitchin and Brown, 1987; Witschi, 1986; JECFA, 1986a, 1986b). Furthermore, in rodents there is sufficient evidence of carcinogenicity of BHA in the forestomach (Ito et al., 1985, 1986, 1988; Masui et al., 1986; Clayson et al., 1986) and possibly also of BHT in the liver (Olsen et al., 1986; Lindenschmidt et al., 1986; Inai et al., 1988). Risk assessment of human consumption of BHA and BHT is complicated by the fact that the mechanism of their carcinogenicity is not known; both antioxidants exert no genotoxic activity (Anonymous, 1986a $1986^{\mathrm{b}}$; Hageman et al., 1988). The FAO/WHO Joint Expert Committee on Food Additives (JECFA) recently established a temporary ADI 
for BHA of 0-0.5 $\mathrm{mg} / \mathrm{kg}$ body weight (JECFA, 1989) and $0-0.125 \mathrm{mg} / \mathrm{kg}$ for BHT (1ECFA, 1986 b). In addition, the Scientific Committee for Food of the Commission of the European Communities also set an ADI for BHA at $0-0.5 \mathrm{mg} / \mathrm{kg}$, but for BHT only at 0$0.05 \mathrm{mg} / \mathrm{kg}$ (Haigh, 1986; Anonymous, 1987).

Accurate data on the daily intake of BHA and/or BHT by man are not available. Estimates range from 0.05-3 mg/day (FASEB, 1978) to 0.5 $1.5 \mathrm{mg} / \mathrm{kg} / \mathrm{day}$ (Malkinson, 1983), but generally are in the range of 1-15 mg/day (Kirkpatrick and Lauer, 1986; Anonymous, 1986a ${ }^{\mathrm{a}}$ 1986 $\mathrm{b}$; Kahl, 1984; CIAA, 1985; Collings and Sharratt, 1970; Kangsadalampai et al., 1986). However, most estimates are based on either confidential data or reports that are not readily availlable. Only Kirkpatrick and Lauer (1986) gave a clear insight into the data on which their assessment of phenolic antioxidant intake in Canada and the USA in the 1970's was founded.

This study sets out to estimate quantitatively the actual age- and sex-related daily maximal possible dietary intake of BHA and/or BHT in The Netherlands. Estimates are based on the fat content of seven out of twenty-three selected food categories. It has been assumed that all consumed fat contained maximal permitted levels of antioxidants, and that these antioxidants are BHA and/or BHT. Risk assessment for BHA and BHT has been performed by comparing the estimated BHA- and/or BHT-intake with the current ADI's for these food additives.

\section{Experimental}

The potential dietary BHA and/or BHT intake in The Netherlands was calculated using data of a nationwide dietary record survey (Anonymous, 1988), as proposed by the Dutch Nutritional Council in 1986. This survey, funded by the Dutch mimistries of Welfare, Health and Cultural Affairs, and of Agriculture and Fisheries, was carried out in 1987/1988, and included 2204 households, with a total of 5898 participants representative for the Dutch population within the age of 1-75 years. Participants recorded their consumption of food and drinks for two consecutive days. Collection of data was uniformlly spread over the seven days of the week and the four seasons. No data were collected during holidlays and vacation periods.

Seven out of the twenty-three distinguished food categories were selected that could possibly contain BHA and/or BHT" (Table 13-1). The first criterium for this sellection was the legally permitted use for $B H A$ and/or $\mathrm{BHT}$ in The Netherlands; the second criterium involved a selection of foodstuffs for which a need for protection by antioxidants has been reported (CIAA, 1985; Haigh, 1986).

Estimates of dietary BHA and/or BHT intake were based on the consumption of fat via the above mentioned selected food categories. It was assumed that all consumed fal contained maximal permitted levels of antioxidants, according to Dutch legislation, and that these antioxidants were BHA andior BHT (Table 13-11). Thus, in this maximal-approach BHA and/or BHT intake was calculated using data on average fat consumption according to the equation:

$$
\text { BHA and/or BHT intake }=\sum_{1}^{f c}(\mathrm{~F})_{f c}(\mathrm{ML})_{f c}
$$

in which $f c$ stands for the selected food categories, $F$ stands for the average fat consumption via the selected food category, and ML is the maxinnally permitted level of BHA and/or BHT in the fat. 
TABLE 13-I: DISTINGUISHED FOOD CATEGORIES USED IN THE NATIONWIDE DIETARY RECORD SURVEY IN THE NETHERLANDS IN 1987/1988.

\begin{tabular}{lll}
\hline nIr & food category & possibly containing BHA and/or BHT \\
\hline 1 & potatoes and tuberous plants & yes \\
2 & cereals and cerealproducts & yes \\
3 & fats, oils, mayonnaise etc. & yes \\
4 & soup & yes \\
5 & pastry, cake and biscuits & yes \\
6 & sugar, sweets and sweetspreads & yes \\
7 & nuts, seeds and snacks & yes \\
8 & vegetables & \\
9 & pulses & \\
10 & fruit & \\
11 & bread & \\
12 & milk and millkproducts & \\
13 & cheese & \\
14 & eggs & \\
15 & meat, meatproducts and poultry & \\
16 & fish and shellfish & \\
17 & composed dishes & \\
18 & peanutbutter, spreads etc. & \\
19 & non-alcoholic beverages & \\
20 & alcoholic beverages & \\
21 & herbs and spices \\
22 & preparations & \\
23 & miscellaneous \\
\end{tabular}

a: adapted in part from Anonymous (1988).

TABLE 13-II: MAXIMALLY PERMITTED LEVELS FOR BHA AND BHT IN FOOD IN THE NETHERLANDS ${ }^{\mathrm{A}}$.

\begin{tabular}{ll}
\hline food product & BHA and/cr BHT b \\
\hline oils and fats $\mathrm{c}$ & $100 \mathrm{mg} / \mathrm{kg}$ \\
biscuits & $400 \mathrm{mg} / \mathrm{kg}^{\mathrm{d}}$ \\
soup & $100 \mathrm{mg} / \mathrm{kg}^{\mathrm{d}}$ \\
flawors & $200 \mathrm{mg} / \mathrm{kg}$ \\
ethereal oils & $1000 \mathrm{mg} / \mathrm{kg}$
\end{tabular}

a: adapted in part from Staarink and Hakkenbrak (1985);

b: alone or in combination with other antioxidants;

c: with the exception of margarine and (cacao)butter;

d: based on the fat content. 
Since addition of BHA and BHT is not allowed in margarine and butter, corrections were made for category 3. This could be performed since this food category was further differentiated. The fat content of emulsified sauces in category 3 was set al $25 \%$. Because of the fact that no distinction could be made between BHA and BHT, all data are referred to as "BHA and/or BHT'. Therefore, "BHA and/or BHT" may be interpreted as either exclusively BHA, or as exclusively BHT, or as an unknown ratio of BHA and BHT.

Since different ages reflect different body weights, the estimated daily BHA and/or BHT consumption is expressed on a dose/ body weight basis, using average age-related body weights as reported by Chenault (1984).

Further, an attempt has been made to differentiate between subjects with a higher or lower fat intake, which would result in a higher or lower estimated BHA and/or BHT intake. For that purpose, the inter-individual wariation in total fat consumption (i.e. over all twenty three food categories) was taken as the possible interindividual variation in BHA and/or BHT intake. By this method the mean, median, minimal and maximal daily dietary BHA and/or BHT intake as well as the standard deviation of estimates wene calculated. Estimates do not reflect individual differences in BHA and/or BHT intake, since no individual food consumption data were available.

\section{Results}

Table 13-III gives an example of the calculation of the average BHA and/or BHT consumption for all ages $(n=5898)$ based on the fat content of seven out of twenty three selected food categories (from Table 13-1), their respective maximal permitted BHA and/or BHT levels and the consumption of fat via these food categories. The highest contribution to the consumption of BHA and/or BHT is made by pastries, cakes and biscuits (category 5 ) in all age and sex groups.

On average, based on this maximal-approach, BHA and/or BHT intake is $4.51 \mathrm{mg} /$ day or $0.075 \mathrm{mg} / \mathrm{kg} / \mathrm{day}$ for a $60 \mathrm{~kg}$ individual. Estimates for all different age and sex groups range from $2.31 \mathrm{mg} /$ day in $1-3$ years old children to $5.76 \mathrm{mg} /$ day in male adolescents $(16-21$ years). Figure 13-1 summarizes the results of the maximal-approach on dietary BHA and/or BHT intake for all classes of Dutch inhabitants expressed on a dose/body weight basis. In addition to average BHA and/or BHT intake, the standlard deviation and maximal intake for subjects are indicated. Minimal intake is, as a rule, close to zero (data not shown). Median fat (and consequently BHA and/or BHT) intake is $95.3 \pm 1.2 \%$ of mean fat intake, as has been calculated for all age and sex groups. The estimated BHA and/or BHT intake was significantly higher in females vs males for the age groups 10-15, 22-49 and 50-64 years $(\mathrm{P}<0.001)$ and the age group $65+$ years $(\mathrm{P}<0.02)$ (Student's t-test for unpaired values).

The current ADI's (0-0.5 mg/kg for BHA and 0-0.125 and 0-0.05 mg/kg for BHT)(JECFA, 1986 b, 1989; Haigh, 1986; Anonymous 1987) have also been indicated for comparison. If BHA and/or BHT intake would represent exclusively consumption of $\mathrm{BHA}$, only in children, aged 1-6 years, the possibility exists that the ADI may be surpassed. However, if intake would be exclusively BHT, it is well possible that the present set ADI's for BHT could be exceeded in all age and sex groups. Particularly younger children may ingest an amount of BHT about ten times the lowest ADI set for BHT $(0-0.05 \mathrm{mg} / \mathrm{kg})$. 


\section{TABLE 13-III: MAXIMAL POSSIBLE AVERAGE BHA AND/OR BHT INTAKE FROM DIFFERENT FOOD CATEGORIES}

\begin{tabular}{|c|c|c|c|}
\hline category $y^{a}$ & $\begin{array}{l}\text { average consumed } \\
\text { amount of fat } \\
(\mathrm{g} / \mathrm{day})\end{array}$ & $\begin{array}{l}\text { maximal permitted } \\
\text { level of BHA and/or BHT } \\
(\%)\end{array}$ & $\begin{array}{l}\text { maximal possible } \\
\text { intake of BHA and/or BHT } \\
\text { (mg/day) }\end{array}$ \\
\hline 1 & 2.0 & 0.01 & 0.2 \\
\hline 2 & 0.4 & 0.01 & 0.04 \\
\hline $3^{b}$ & 2.2 & 0.01 & 0.22 \\
\hline 4 & 1.6 & 0.01 & 0.16 \\
\hline 5 & 7.2 & 0.04 & 2.88 \\
\hline 6 & 2.9 & 0.01 & 0.29 \\
\hline \multirow[t]{2}{*}{7} & 7.2 & 0.01 & 0.72 \\
\hline & & SUM: & $4.51 \mathrm{mg}$ \\
\hline
\end{tabular}

\section{a: See Table 13-I.}

b: Corrections have already been made for the consumption of margarine and butter, which are not allowed to contain BHA and BHT. Actual fat consumption in this category was $33.5 \mathrm{~g}$.

Calculation of the average daily dietary BHA and/or BHT intake in The Netherlands for all participants $(n=5898)$ based on a maximal approach.

\section{Discussion}

There is sufficient evidence of carcinogenicity of BHA and possibly also of BHT in experimental animals (Ito et al., 1985, 1986,1988; Masui et al., 1986; Clayson et al., 1986; Olsen et al., 1986; Lindenschmidt et al., 1986; Inai et al., 1988). Both food antioxidants, although complete carcinogens, are thought to exert their tumorigenicity via non-genotoxic mechanisms (Anonymous, 1986a $1986^{\mathrm{b}}$; Hageman et all, 1988). Therefore, current ADI's for $B H A$ and $B H T$ are based on the no effect level- safety factor approach (JECFA, 1986b,1989; Haigh, 1986; Anonymous, 1987) taking tumorigenicity-related changes in to account. In the present study, risk assessment for BHA and BHT is performed by comparing the estimated BHA and/or BHT intake by man in The Netherlands based on a maximal-approach with the ADI's for these food additives. Results indicate that it is unlikely that the current ADI for BHA $(0-0.5 \mathrm{mg} / \mathrm{kg})$ is exceeded, but indicate also that it cannot be excluded that the ADI for BHT $(0-0.125 \mathrm{mg} / \mathrm{kg}$ and $0-0.05 \mathrm{mg} / \mathrm{kg})$ is surpassed at all ages and both sexes.

Several methods for the assessment of dietary BHA and/or BHT intake have been reported. Van Dokkum et al. (1982) performed a market-basket study followed by chemical analysis of homogenized foods, and detected BHA, but not BHT, in the food category 'fish', although in a limited number of samples only. They concluded that maximal BHA intake by male adolescents in The Netherlands was $4 \mathrm{mg} /$ person/day, which is in line with the present results. However, due to dilution of BHA and/or BHT in the homogenization procedure this methodology has the disadvantage of rather a high detection limit.

The BHA and/or BHT intake may alternatively be estimated from the amount of antioxidants sold to manufacturers (CIAA, 1985; Rehwoldt, 1986). However, these data are as a rule prone to confidentiality and therefore not regularly available. Based on such confidential data, the CIAA (1985) estimated a dally average intake of $1 \mathrm{mg} /$ person in adults in countries 

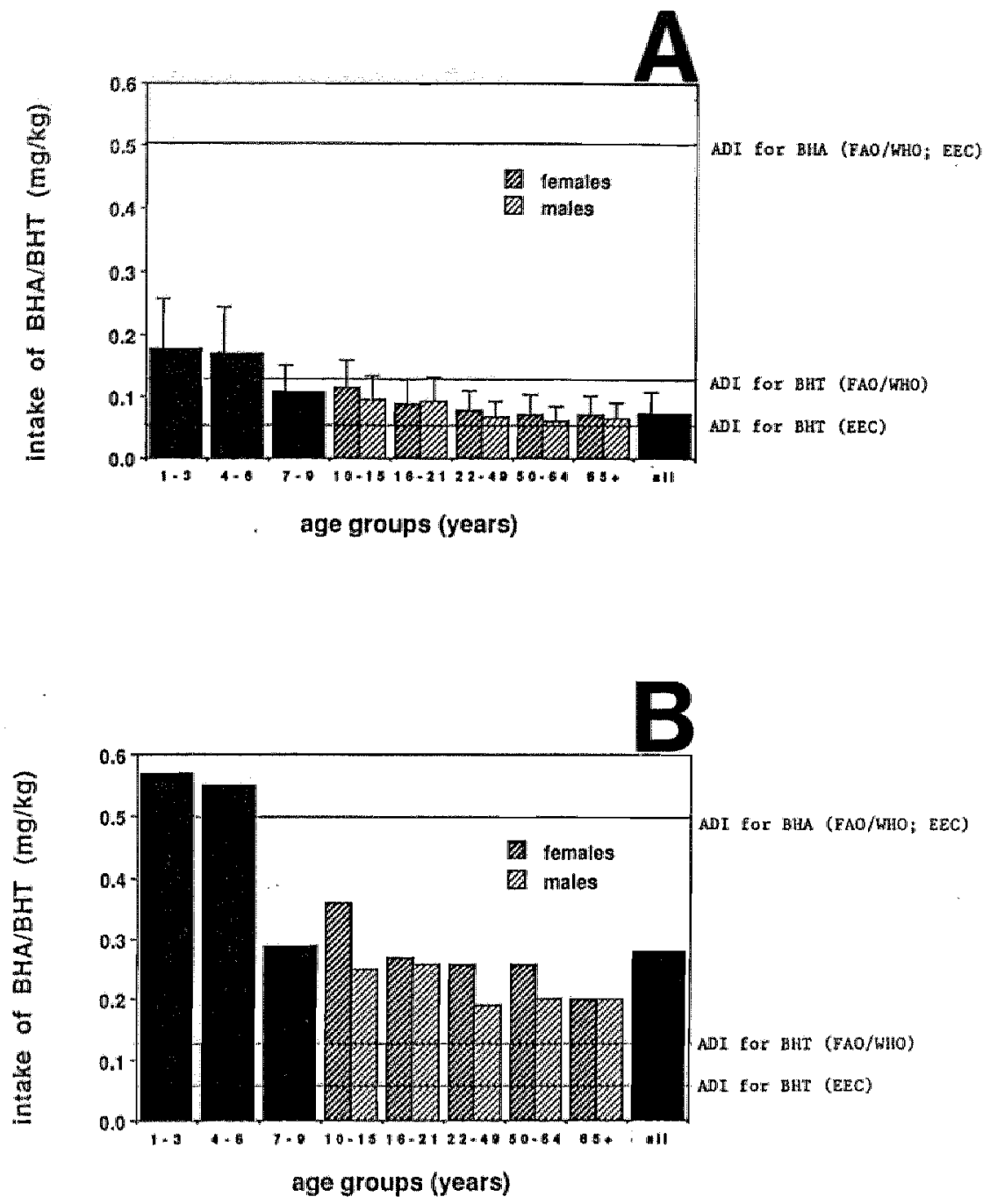

Figure 13-1: Estimated daily intake of BHA andlor BMT from food in The Netherlands, subdivided into different age groups and boith sexes. Data represent a maximal-approach, based on the assumption that all food products, in which these additives are allowed, contain maximally permitted levels of BHA andlor BMT. Figure 13-Ia shows the mean \pm SD of the estimates; Figure 13-1b shows the maximal intake of BHA andior BHT. The lower range is not indicated but is close to zero in all instances. No distinction between the sexes was made in the age groups 1-3, 4-6 and 7-9 years (black bars). For comparison, the present esiablished ADI's for BHA (O.5 $\mathrm{mg} / \mathrm{kg})$ and BHT $(0.0 .125$ and $0.0 .05 \mathrm{mg} / \mathrm{kg})$ are indicated. 
of the EEC for all food antioxidants together (i.c. BHA, BHT, gallates, tocopherols and ascorbylpalmitate), increasing to $3 \mathrm{mg} /$ person for individuals with largely aberrant dietary habits.

Another method is based on the consumption of fat by man and the maximal BHA and/or BHT content of fats, possibly corrected for the consumption of fat from foods in which BHA and BHT are not allowed. Most reports estimating the daily dietary BHA and/or BHT intake by man are based on this methodology (CIAA, 1985; Kirkpatrick and Lauer, 1986). Daily dietary fat consumption has either been estimated from the percentage caloric intake via fat (CIAA, 1985) or by a dietary recall survey (Kirkpatrick and Lauer, 1986). The CIAA (1985) estimated a maximal total antioxidant intake of $14 \mathrm{mg} /$ person/day for adults in EEC countries. Kirkpatrick and Lauer (1986) estimated that the dietary intake of BHA and other permitted phenolic antioxidants (BHT and propyl gallate) was unlikely to exceed 1 $\mathrm{mg} / \mathrm{kg} /$ day and on average was less than $0.4 \mathrm{mg} / \mathrm{kg} /$ day. Although Kirkpatrick and Lauer (1986) indicated that younger children constitute a potential risk group for dietary BHA and/or BHT intake, which is in line with the present study, their report is not applicable to the Dutch situation, owing to a legal difference in permitted use of BHA and/or BHT in Canada and the USA, as well as to a difference in feeding pattern in those countries vs The Netherlands. For instance, the main contribution to BHA and/or BHT intake in the study of Kirkpatrick and Lauer (1986) is made by cereals, a food group which is not consumed as largely in The Netherlands as compared to Canada or the USA. Moreover, unlike in The Netherlands, BHA and BHT are legally permitted in bread, butter and margarine in Canada and the USA.

In contrast to the method of Kirkpatrick and Lauer (1986), in the present report the estimated BHA and/or BHT intake in The Netherlands was based on a two-day dietary record survey, including all age groups and both sexes. It is emphasized that the present estimates of BHA and/or BHT intake were based on a maximal approach assuming that all fat of the included food categories contained maximally permitted levels of antioxidants, according to Dutch legislation, and that these antioxidants were BHA and/or BHT. The estimates did neither account for losses of BHA and/or BHT during storage or food processing nor for lower levels of BHA and/or BHT in food products as a result of intentional limited use by the manufacturer nor for the addition of other antioxidants (e.g. tocopherols, gallate-esters, etc.; Sims and Fioriti, 1980). Reported values may also have been over-estimated as some food categories (e.g. category 6) might have comprised food items that are not allowed to contain BHA and/or BHT (e.g. chocolate). Consequently, the actual BHA and/or BHT intake might be lower than the estimated levels of intake. However, these over-estimates are counterbalanced to some extent by the fact that not all food products that might contain BHA and/or BHT have been included in the selected food categories. It is conceivable that food products in categories 15,16,17 and 18 also occasionally contain BHA and/or BHT. In addition, the possibility of migration of BHA and BHT from packaging materials, especially those that are waxed, into foods may also contribute to a higher BHA and/or BHT intake by man (Sims and Fioriti, 1980; Schroeder, 1973; Bieber et al., 1984; Anonymous, 1986a, 1986b). Thus, although the applied methodology may have advantages in comparison with other reported methods, several factors may have given rise to aberrant estimates of the actual daily BHA and/or BHT consumption in The Netherlands.

If the estimated maximal possible antioxidant intake would be exclusively BHA, results indicate that it is unlikely that the actual daily dietary consumption of BHA by man in The Netherlands will exceed the ADI for this agent. It is not clear whether this unequivocally implies that the present application of BHA as a food additive should be considered safe. It 
has prewiously been shown that oral administration of the ADI for BHA $(0.5 \mathrm{mg} / \mathrm{kg})$ to man and a 400 times higher dose to rat $(200 \mathrm{mg} / \mathrm{kg}$ ) resulted in plasma BHA levels within one order of magnitude (Verhagen et al., 1989), which indicates that the current ADI for BHA might not be sufficient to protect man for the possibly adverse effects associated with dietary BHA consumption. The ADI for BHA is based on a no-effect level of $62.5 \mathrm{mg} / \mathrm{kg}$ body weight for the induction of proliferative changes in rat forestomach (JECFA, 1986a), indicating that a toxic effect of BHA in man would probably involve a proliferation stimulating effect.

If the estimated maximal antioxidant intake would represent exclusively BHT, it cannot be excluded that the ADI's for BHT may be exceeded in all age and sex groups. Therefore, its application as a food additive may not be considered safe. Specifically the blood coagulation system would probably be the target of BHT toxicity in man, since the lowest ADI for BHT $(0-0.05 \mathrm{mg} / \mathrm{kg})$ is based on a no-effect level for (transient) hemorrhagic effects following administration of about $5 \mathrm{mg} \mathrm{BHT} / \mathrm{kg}$ body weight in a short-term experiment with rats (Anonymous, 1987).

In conclusion, based on maximal-approach, it is unlikely that the estimated average daily dietary intake of BHA by man in The Netherlands will exceed the ADI. However, it cannot be excluded that the ADI for BHT is exceeded in all age and sex groups. As a result of the high potential consumption of BHT, younger children form a risk group for the toxic effects of $\mathrm{BHT}$.

\section{References}

- Anonymous. (1984). Final Report of the safety assessment for BHA. Journal of the American College of Toxicology 3: 83-146.

- Anonymous. (1986 $6^{\text {a }}$. Butylated hydroxyanisole (BHA). IARC Monographs on the evaluation of the carcinogenic risk of chemicals to humans. 40: 123-159.

- Anonymous. (1986 b). Butylated hydroxytoluene (BHT). IARC Monographs on the evaluation of the carcinogenic risk of chemicals to humans. 40: 161-206.

- Anonymous. (1987). Report of the Scientific Committee for Food of the Commission of the European Communities on antioxidants. CS/ANT/20-Final.

- Anonymous (1988). Wat eet Nederland. Resultaten wan de voedselconsumptiepeiling 1987-1988. Ministerie van Wolzijn, Volksgezondheid en Cultuur en Ministerie van Landbouw en Visserij. (in Dutch; surmmary in English).

- Bieber W.D., Freytag W., Figge K, and vom Bruck C.G. (1984). Transfer of additives from plastic materials into foodstuffs and into food-simulants - a comparison. Food and Chemical Toxicology 22: $737-742$.

- Chenaull A.A. (1984). Nutrition and Health. CBS College Publishing Hold, Rinehart and Winstion, New York.

- Confederation des industries agro-alimentaires de la CEE. (CIAA)(1985). Antioxidants. A dossier prepared by the CIAA for submission to the EEC Scientific Committee for Food. ADD-8/85-Final.

Clayson D.B., Irerson F., Nera E., Lok E., Rogers C., Rodrigues C., Page D., and Karpinski K. (1986). Histopathological and autoradiographical studies on the forestomach of F3.44 rats treated with butylated hydroxyanisole and related chemicals. Food and Chemical Toxicology 24: 1171-1182.

- Collings A.J. and Sharratt M. (1970). The BHT content of human adipose tissue. Food and Cosmetic Toxicology 8: $409-412$.

- van Dokkum W., de Vos R.H., Cloughley F.A., Hulshof K.F.A.M., Dukel F. and Wijsman J.A. (1982). Food additives and food components in total diets in the Netherlands. British Journal of Nutrition 48: 223-231.

- FASEB (1978). Evaluation of the health aspects of butylated hydroxyanisole as a food ingredient. cited in Anonymous (1984). 
- Hageman G.J., Verhagen H.。 and KUeinjans J.C.S. (1988). Butylated hydroxyanisole, butylated hydroxytoluene, and tert-butylhydroquinone are not mutagenic in the Salmonella/microsome assay using new tester strains. Mutation Research 208: 207-211.

- Haigh R. (1986). Safety and necessity of antioxidants: EEC approach. Food and Chemical Toxicology 24: 1031-1034.

- Hocman G. (1988). Chemoprevention of cancer: phenolic antioxidants (BHT, BHA). International Journal of Biochemistry 7: 639-651.

- Inai K., Kobuke T., Nambu S., Takemoto T., Kou E., Nishina H., Fulihara M., Yonehara S., Suehiro S. Tsuya T., Horiuchi K. and Tokuoka S. (1988). Hepatocellular tumorigenicity of butylated hydroxytoluene administered orally to B6C3F1 mice. Gann 79: 49-58.

- Ito $\mathrm{N}$. and Hirose M. (1987). The role of antioxidants in chemical carcinogenesis. Gann 78: 1011-1026.

- Ito N., Fukushima S. and Tsuda H. (1985), Carcinogenicity and modification of the carinogenic response by BHA, BHT and other antioxidants. C.R.C. Critical Reviews in Toxicology 15: 109-150.

- Ito N., Fukushima S., Tamano S., Hirose M., and Hagiwara A. (1986). Dose response in butylated hydroxyanisole induction of forestomach carcinogenesis in 1344 rats. Journal of the National Cancer Institute 77: 1261-1265.

- Iverson F., Truelove J., Nera E., Wong J., Lok E. and Clayson D.B. (1985) An 85-day study of butylated hydroxyanisole in the cynomolgus monkey. Cancer Letters 26: 43-50.

- Joint FAO/WHO Expert Committee on Food Additives (1986a). Toxicological evaluation of certain food additives and contaminants. Butylated hydroxyanisole (BHA). WHO Food Additives Series 21:3. 24.

- Joint FAO/WHO Expert Committee on Food Additives (1986 b). Toxicological evaluation of certain food additives and contaminants. Butylated hydroxytoluene (BHT). WHO Food Additives Series 21: 2546.

- Joint FAO/WHO Expert Committee on Food Additives (1989). Evaluation of certain food additives and contaminants. WHO Technical Report Series 776: 14-15.

- Kahl R. (1986). The dual role of antioxidants in the modification of chemical carcinogenesis. Journal of Enwironmental Science and Health C4(1): 47-92.

- Kangsadalampai K., Sharma R.P., Taylor MJ. and Salunkhe D.K. (1986). Effect of protein deficiency and Tween 60 on the pharmacokinetics of butylated hydroxyanisole and metabolites in male SpragueDawley rats. Drug-Nutrient Interactions 4: 289-297.

- Kirkpatrick D.C. and Lauer B.H. (1986). Intake of phenolic antioxidlants from foods in Canada. Food and Chemical Toxicology 24: 1035-1037.

- Kitchin K.T. and Brown J.L. (1987). Biochemical effects of two promotors of hepatocarcinogenesis in rats. Food and Chemical Toxicology 25: 603-607.

- Malkinson A.M. (1983). Review: putative mutagens and carcinogens in foods. III. Butylated hydroxytoluene (BHT). Environmental Mutagenesis 5: 353-362.

- Masui T., Hirose M., Imaida K., Fukushima S., Tamano S. and Ito N. (1986). Sequential changes of the forestomach of $\mathrm{F} 344$ rats, Syrian golden hamsters, and $\mathrm{B} 6 \mathrm{C} 3 \mathrm{~F}$, mice treated with butylated hydroxyanisole. Gann 77: 1083-1090.

- Olsen $\mathbb{P}_{1}$, Meyer O., Bille N., and Wirtzen G. (1986). Carcinogenicity study on butylated hydroxytoluene (BHT) in Wistar rats exposed in utero. Food and Chemical Toxicology 24: 1-12.

- Rehwoldt R. (1986). Tracking the use of antioxidants through industry surveys. Food and Chemical Toxicology 24: 1039-1041.

- Schroeder E. (1973). The development of methods for examining stabilizers in polymers and their conversion products. Pure and Applied Chemistry 36: 233-255.

- Sims R.J. and Fioriti J.A. (1980) Antioxidants as stabilizers for fats, oils, and lipid-containing foods. In: CRC Handbook of food additives, Vol. II, edited by T.E. Furia, 2nd Ed. pp. 13-56. Chemicall Rubber Company, Boca Raton, FL.

- Staarink T. and Hakkenbrak P. (1985). Het additievenboekje. Een overzicht van toevoegingen aan drinken eetwaren. Staatsuitgeverij, "s-Gravenhage, The Netherlands (in Dutch).

- Verhagen H., Thijssen H.H.W., ten Hoor F. and Kleinjans J.C.S. (1989) Disposition of single oral doses of butylated hydroxyanisole in man and rat. Food Chem. Toxicol. 27: 151-158.

Wattenberg L.W. (1985). Chemoprevention of cancer. Cancer Research 45:1-8.

- Witschi H.P. (1986). Enhanced tumour development by butylated hydroxytolwene (BHT) in the liver lung and gastro-intestinal tract. Food and Chemical Toxicology 24: 1127-1130.

- Wuirtzen G. and Olsen P. (1986). BHA study in pigs. Food and Chemical Toxicology 24: 1229-1233. 



\section{Chapter 14}

\section{General discussion}

In chapter 1 it was stated that the current ADI's for BHA and BHT were based on insufficient experimental data. Therefore it was aimed in this thesis to increase knowledge on the biological fate of BHA and BHT in man vs rat, on the mechanism underlying the carcinogenicity of BHA and BHT in experimental animals, on the recognition of potential target tissues for this carcinogenic action, and on the actual daily intake of BHA and BHT by man. Additional data would support the assessment of potential health risks associated with consumption of these food additives by man: a comparison of concentrations of an agent at (target) tissues between man and animal, as reflected by its plasma levels, provides a more physiological basis for risk assessment, than does the comparison of doses ( $\mathrm{mg} / \mathrm{kg}$ body weight). Analysis of metabolic pathways may recognize the possibility of bioactivation of a compound. Moreover, understanding the mechanism by which carcinogenic compounds exert their action in experimental animals is of utmost importance in determining the specific risk extrapolation model. It is conceivable that potential food additives, if they appear to be stochastically operating carcinogens, will mever be acceptable for human consumption. Since exposure to an agent is a prerequisite for a toxic (and carcinogenic) response to occur, quantitative assessment of the daily intake of an agent is obligatory for risk evaluation.

The results described in this thesis do not give definite answers to all questions. Although information on BHA and BHT has been extended, numerous problems remain and novel uncertainties have arisen. The general outcome of the thesis, based on chapters $2-13$, is briefly summarized in Table 1 . The majority of data concerns BHA, which agent appeared to be the most interesting from a toxicologist's point of view. It could easily be analyzed with respect to its fate in man and rat and exhibited reproducible proliferation enhancing effects in the gastro-intestinal tract of rats.

Methods for the quantization of BHA and BHT have been presented in chapters 2-4. Chemical analysis of BHA in body fluids can be performed in every laboratory equipped with a high-performance liquid chromatography (chapter 2). The same holds for chemical analysis of BHT, although it is rather laborious to achieve a sufficiently low detection limit (chapter 3). In (carcinogenicity) studies on BHA it is good practice to indicate the ratio of 2 and 3-BHA isomers, since most experiments deal with crude, possibly food-grade, BHA. A simple and rapid method for the determination of isomer ratios of BHA is described in chapter 4.

In chapters 5-7, plasma BHA and BHT levels have been compared between man and rat following a single oral dose of these antioxidants. These experiments were performed in order to compare the concept of concentrations of an agent at (target) tissue sites, reflected by its plasma levels, with the concept of doses (in $\mathrm{mg} / \mathrm{kg}$ body weight) to determine an acceptable daily intake (ADI) for man. In an experiment studying the fate of BHT after a single oral dose of $0.5 \mathrm{mg} / \mathrm{kg}$ in man and $20-200 \mathrm{mg} / \mathrm{kg}$ in rat, plasma levels in man and rat 


\section{TABLE 14-1: BRIEF OVER VIEW OF THE OUTCOME OF THE THESIS}

\begin{tabular}{|c|c|c|c|}
\hline Subject of investigation & BHA & BHT & Chapter \\
\hline * chemical analysis & simple & Laborious & $2-4$ \\
\hline * fate in main ws rat & $\begin{array}{l}\text { reason for concern } \\
\text { (based on kinetics } \\
\text { and metabolism) }\end{array}$ & $\begin{array}{l}\text { no reason for concern } \\
\text { (based on kinetics) }\end{array}$ & $5-7$ \\
\hline $\begin{array}{l}\text { * subacute administration } \\
\text { to male wollunteers }\end{array}$ & $\begin{array}{l}\text { possibility of bioaccumulation } \\
\text { and/or enzyme induction }\end{array}$ & - & 8 \\
\hline * mutagenic activity in vitro & absent & absent & 9 \\
\hline $\begin{array}{l}\text { * carcinogenicity-related } \\
\text { effects }\end{array}$ & $\begin{array}{l}\text { affecting several gastro- } \\
\text { intestinal tract tissues in rat }\end{array}$ & - & $10-12$ \\
\hline $\begin{array}{l}\text { * daily dietary intake by man } \\
\text { in The Netherlands }\end{array}$ & below the $A D I$ & $\begin{array}{l}\text { possibility of exceeding } \\
\text { the ADI recognized }\end{array}$ & 13 \\
\hline
\end{tabular}

-: nat subjected to investigation

were largely different, generally by at least a factor 10 (chapter 7). In contrast, an experiment on comparative metabolism and kinetics of BHA in man vs rat revealed that, despite a 400 times difference in dose, plasma BHA concentrations reached in man after oral ingestion of $0.5 \mathrm{mg} / \mathrm{kg}$, were in the same order of magnitude as those attained in rat following a single oral dose of $200 \mathrm{mg} / \mathrm{kg}$. In addition, in the same experiment in man, but not in rat, $51 \%$ of the ingested amount could not be recovered from urine and feces, collected on four consecutive days following BHA administration, indicating the possibility of bioaccumulation and/or unknown biotransformation pathways of BHA in man. It is concluded that the fate of BHA in man is very different from that in rat. Therefore it is questioned whether the safety factor applied in the calculation of an ADI of BHA for human consumption $(0.5 \mathrm{mg} / \mathrm{kg})$ would be sufficient to protect man against possible adverse effects of dietary BHA intake (chapter 5). Therefore further research on the fate of BHA in man is indicated. In rat, extensive biliary excretion of conjugated BHA was found, indicating the possibility of entero-hepatic circulation in this species (chapter 6).

In order to study the possibility that BHA might induce any effect in man, an experiment was performed to determine the effects of subacute oral BHA administration $(0.5 \mathrm{mg} / \mathrm{kg}$ daily) on biotransformation capacity and on a number of clinicall parameters. Eight male volunteers ingested BHA for 10 consecutive days (chapter 8). Alteration of biotransformation enzymes by BHA was thought to impart in the modulation of the toxicity, mutagenicity and tumorigenicity of specific chemicals in vivo and in vitro (chapter 1). In this study, no changes in standard clinical parameters were demonstrated. Using antipyrine and paracetamol as test-substances, no effects were detected either on general phase-I and -II metabolic capacity in man, indicating that in this experiment BHA does probably not alter the susceptibility of man to xenobiotics by influencing their metabolism. In contrast, the amount of phase-I and -II derived metabolites of BHA, which were excreted into urine, was gradually increased, indicating the possibility of induction or inhibition of BHA-specific biotransformation enzymes and/or of bioaccumulation of (metabolites of) BHA. The possible retention of BHA or of its metabolites in the body strengthens the results presented in chapter 5. Again further research on the fate of BHA in man is indicated.

Part IV comprises several studies trying to unravel the unknown mechanism underlying the 
carcinogenicity of BHA (and BHT). In an in vitro experiment, studying the mutagenicity of BHA and BHT in the Salmonella/microsome assay using the new tester strains TA97, TA102 and TA104, it was confirmed that, BHA and BHT although complete carcinogens do not possess mutagenic activity in prokaryotic systems (chapter 9). In an in vivo experiment, determining the labelling index and other cell kinetic parameters in rat gastro-intestinal tract tissues by flow cytometry and immunocytochemistry, proliferation emhancing effects of BHA in the forestomach are reported, which is a confirmation of findings by others (chapter 10). By application of this method, in combination with chemical analyses of (conjugated) BHA and its metabolite (conjugated) tert-butylhydroquinone (TBHQ) described in chapter 5 , evidence was presented that it is most unlikely that oxidative cytochrome $\mathrm{P} 450$-mediated demethylation of BHA into TBHQ is involved in BHA-induced cell proliferation in rat forestomach, in particular since TBHQ formation appeared not to be related to the oral dose of BHA (chapter 11).

In a fourth study (chapter 12) it was shown that in rat not only the forestomach, but also the oesophagus, glandular stomach, small intestine and large bowel should be considered as possible target tissues for the proliferation stimulating effects of BHA. In the forestomach, glandular stomach, small intestine and colon/rectum, mean tissue labelling index (LI) was significantly increased in rats on a diet containing $2 \%$ BHA as compared to rats fed the basal diet ad libitum or to a pair-fed control (PFC) group of rats given basal diet restricted to the mean daily intake of $2 \% \mathrm{BHA}$-fed rats. In this experiment, in the oesophagus of rats fed $2 \%$ BHA the LI was significantly increased vs the PFC group but not vs the group of rats fed basal diet ad libitum. In the forestomach of rats an apparent no-effect level (NEL) for ad libitum fed rats was found at $0.50 \%$ BHA (LI) and at $0.75 \%$ BHA (potential doubling time). These findings implicate that BHA affects not only squamous epithelial cells, but other cell types as well. These novel data underline the need for further studies on the unknown mechanism of the induction of proliferative changes in digestive tract tissues and of tumors in the forestomach of rats.

Since there is no toxic effect unless there is exposure to an agent, in chapter 13 the estimated maximal daily dietary intake of BHA and BHT in the Netherlands has been evaluated with respect to the presently established ADI's for these food additives. Results from this study indicate that, based on a maximal-approach, it is unlikely that the ADI for BHA is surpassed by man; the ADI for BHT, however, may be exceeded in all age and sex groups by daily dietary food consumption. Particularly, younger children from $1-6$ years old form a potential risk group, owing to a relatively high food consumption in comparison with their body weight.

When comparing the estimated maximal daily dietary intake of BHA and BHT with their respective ADI's, it is concluded that the present application of BHA as a food additive should be considered safe, but that the application of BHT may not be considered safe.

In conclusion, based on the estimated maximal possible daily dietary intake of BHA and BHT in The Netherlands in comparison with the current ADI's for these food antioxidants, as concerns the present application of BHA it is not probable that the ADI will be surpassed, unlike BHT. On the other hand, based on their fate in man vs rat, the application of BHT as a food additive may be considered safe, unlike BHA. However, in both instances risk assessment for the consumption of BHA and BHT by man is prone to uncertainties due to the fact that the mechanism underlying their carcinogenicity in rodents is still not understood. Moreover, in case of BHA, the need for further investigations on the unknown 
mechanism of carcinogenicity is emphasized by the finding that in rat also the oesophagus, glandular stomach, small' intestine and colon/rectum are potential target tissues for the proliferation stimulating effects of $\mathrm{BHA}$.

Therefore, from the studies described in this thesis it is evident that the assessment of risk associated with consumption of BHA and BHT by man still requires additional data. Although BHA is considered to be a non-genotoxic carcinogen, the nature of its tumorigenicity is still unknown. If BHA might happen to be a potentially stochastically operating carcinogen, it will theoretically not be possible to establish a NEL. In the next paragraphs, arguments will be provided to support the view that BHA may have tumorinitiating potential. If $\mathrm{BHA}$ can be considered a potentially stochastically operating carcinogen, risk assessment for BHA would have to be performed via extrapolation models other than the NEL-safety factor approach. In that case, lifetime daily intake of the ADI for BHA $(0.5 \mathrm{mg} / \mathrm{kg})$ by man would result in an unacceptably high potential risk of cancer development $(\mathrm{P}=0.2 \%$; linear extrapolation based on data by Ito et al., 1986). Thus, the nature of the proliferative and carcinogenic mechanism of BHA in experimental animals should be subjected to further investigation. With respect to possible effects of BHA in man, special eraphasis should be paid to the effects of this antioxidant on human cells and tissues in in vitro experiments. Experiments on the mechanism of the carcinogenicity of BHA may be facilitated by the development of an in vitro model to study its proliferative effects. Furthermore, BHA may turn out to be a good model for studies on the mechanism underlying the tumorigenicity and induction of proliferative changes of "epigenetic" operating carcinogens in general.

As is outlined above, a major difficulty in risk assessment is the lack of understanding of carcinogenic mechanisms. Some compounds that lack a response in short-term tests for genetic activity are, in reality, weak mutagens and/or weak carcinogens, and have been designated "epigenetic" carcinogens (Harper and Legator, 1987). Often the term "epigenetic" has been misused in cases where the mechanism by which genetic alterations are induced is not known. Therefore, because of the multitude of mechanisms by which DNA-damage may occur, a distinction between direct and indirect genotoxicity is probably improper and an "epigenetic" carcinogen of a given potency should not be assumed to be safer than a "genotoxic" carcinogen of the same potency (Harper and Legator, 1987). In contrast, other "uthors state that for non-genotoxic ("epigenetic") carcinogens a no effect level may be assumed, while for genotoxic agents no such threshold is thought to exist (Williams, 1986; Blumenthal et al., 1986; Kroes, 1987).

In the cascade of events during tumor development an irreversible DNA affecting event is supposed to be the necessary first step, defined as initiation or mutation, which, may lead to secondary clastogenic effects, like sister-chromatid exchanges, DNA-strand breaks, genetranslocation, gene amplification, etc... (Stark and Wahl, 1984; Longstaff, 1986; Kaufmann, 1989). In vitro bioassays have demonstrated many chemical carcinogens to have genetic activity, indicating their ability to interact with DNA. Although DNA may be not the only cellular target macromolecule, since reactions with electron-rich molecular sites on amino acids or RNA may also play a role, the propagation of neoplastic cells requires that the phenotypic characteristics of these cells are transmitted in a hereditary way, suggesting that DNA must be a major critical target.

BHA may have co-carcinogenic potential, possibly resulting from its strong irritant properties (Riley and Seal, 1968) and its effects on biomembranes (Williams, 1986; Thompson and Moldéus, 1988). There is convincing evidence that BHA is a tumor 
promotor (e.g. in rodent forestomach; chapter 1; Imaida et al., 1983, 1984). It may well be possible that a direct, cytotoxic or cell-irritating effect of BHA underlies its co-carcinogenic potential and gives rise to forestomach hyperplasia or enhancement of cell proliferation in the gastro-intestinal tract of rats 1 . However, there is "sufficient evidence for carcinogenicity" of BHA in experimental animals (Anonymous, 1986 ), indicating that according to the multi-stage model for tumor development, also initiation of forestomach cells must have occurred.

It is postulated here that BHA gives rise to tumorigenicity in rodent forestomach by induction of heritable changes in DNA, despite its negative responses in short-term tests for genetic activity. In this concept, initiation, the prerequisite for tumor development, is also caused by BHA, possibly in an indirect way. As is outlined below, this is in line with several of the above mentioned proposed mechanisms. However, a direct cell-irritating cytotoxic action of large amounts of BHA to cells lining the lumen of the gastro-intestinal tract may be a prerequisite for an initiation reaction to occur. For ultimate BHA-induced tumor development in rodent forestomach, also promotion and co-carcinogenic capacities of BHA may be required.

There is no evidence supporting the view that the mechanism underlying the induction of proliferative changes and tumorigenicity in rats is alike. However, there is a close relationship between strong proliferative stimuli and ultimate tumor development (Ghanayem et al., 1986; Kroes and Wester, 1986). Moreover, in case of BHA, Kroes and Wester (1986) note that "the similar curves involved in tumor dose-response and proliferative doseresponse may be another reason to consider hyperplastic factors relevant to forestomach tumor induction". Therefore, it is postulated here that BHA causes proliferation enhancing effects in digestive tract tissues of rodents by induction of heritable changes in DNA.

The hypotheses which suggest that DNA is a cellular target macromolecule for BHA are supported by data of Masui et al. (1986, 1987). In their studies BHA-induced downward basal cell proliferation and basal cell hyperplasia of forestomach squamous epithelial cells are persistent for periods up to 72 weeks after withdrawal of BHA from the diet of rats; one forestomach carcinoma was reported 24 weeks after withdrawal of BHA. Such data indicate the heritable nature of the molecular lesion (i.c. in DNA), as the turn-over rate of other cellular macromolecules, like RNA and protein, is much shorter than 72 weeks (generally in the order of minutes; Alberts et al., 1983).

As is hypothesized, initiation of forestomach cells is caused by direct or indirect genetic activity of BHA. There are no data on DNA-damaging effects of BHA (Anonymous, $1986^{\mathrm{a}}$ ). The general negative response of BHA in short-term tests for mutagenicity and chromosomal effects (e.g chapter 9), could be due to lack of sensitivity of the particular tests, however.

In contrast, several positive responses of BHA in short-term tests for genotoxicity have been cited in chapter 9. Moreover, weak tumor initiating activity of BHA has been found in a two-stage mouse skin carcinogenesis system (Sato et al., 1987). Furthermore, Abraham et al. (1986) reported the appearance of forestomach tumors after only 3 months of feeding $2 \%$ BHA in the diet of rats, following partial hepatectomy as a growth promoting factor, which is an accepted system for studying the neoplastic process in the initiation/promotion concept of tumor development. The data by Abraham et al. (1986) also show that initiation may take place early after administration of BHA.

\footnotetext{
${ }^{1}$ In case of toxic (e.g. tumorigenic) effects of BHA in rodent gastro-intestinal tract tissues, plasma BHA concentrations reached after administration of BHA may be less relevant than such direct, cytotoxic or cell irritating effects.
} 
Several possible mechanisms for the carcinogenic action of BHA in the forestomach of rodents have been proposed, like [1] background exposure to small quantities of exogenously deriwed initiating agents, [2] background initiation by endogenously formed nitrosamines refluxing from the gastric stomach, [3] aberrant DNA-methylation from Sadenosylmethionine to the $\mathbb{N}^{7}$ and $0^{6}$ positions of guanine, [4] inherently instability of forestomach tissue resulting in oncogen-activation, [5] formation of reactive oxygen species in a process of redox-cycling of metabolites of BHA, [6] uncoupling of (mitochondrial) membrane function, [7] depletion of reduced thiols and the formation of protein adducts, [8] pro-oxidant activity, e.g. resulting in the formation of reactive oxygen species, [9] an increase in spontaneous mutations resulting from an increased number of mitoses, and other..... although no convincing evidence to support any has been provided (Kroes and Wester, 1986; Grice et al., 1986; Blumenthal et al., 1986; Kahl and Hildebrandt, 1986).

Future research on genotoxicity of BHA, should focus on different levels of effects on DNA: [1] affecting individual DNA-nucleotides by the formation of specific DNA adducts and [2] affecting DNA resulting in DNA-damage, in point mutations or in chromosomal aberrations.

Initiation may be induced by the formation of DNA-adducts. Determination of BHA-DNA adducts may not be of relevance, since in rat forestomach no radioactivity was found in DNA after administration of ${ }^{14} \mathrm{C}-\mathrm{BHA}$, independent of the molecular location of the radiocarbon label, although some BHA-DNA binding was observed in non-target tissues like liver and kidney (Hirose et al., 1987 a). However, other DNA-adducts may be formed in a process mediated by $\mathrm{BHA}$, leading to ultimate carcinogens with no direct molecular link with BHA.

Active oxygen species may be formed as a result of pro-oxidant activity of BHA (Kahl and Hildebrandt, 1986). Alternatively, metabolism of BHA via cytochrome P-450 and/or prostaglandin synthetase may result in the formation of quinones (e.g. tert-butylquinone and 3-tert-butyl-5-methoxy-1,2-benzoquinone). Rodrigues et al. (1986) reported that coadministration of BHA and acetyl salicylic acid, an inhibitor of prostaglandin synthetase, lowered the BHA-induced increases in forestomach labelling index in rats. Quinones may lead to the formation of active oxygen species either via redox cycling or by arylation of sulfhydryls and subsequent redox cycling (Smith, 1985; Thompson and Trush, 1988). Indeed, sulphur-containing metabolites of BHA have been reported, although their exact nature has not been elucidated (Cummings et al., 1985; DeStafney et al., 1986). Further support for this possibility of bioactivation is provided in a study by Hirose et $\mathrm{al}_{\text {. }}\left(1987^{\mathrm{b}}\right)$, who reported that forestomach hyperplasia in rat as a result of BHA administration disappeared upon simultaneous treatment of rats with the glutathion-depleting agent diethylmaleate.

In all these instances active oxygen species may result in the formation of highly reactive -OH radicals, which readily react with DNA (Vuillaume, 1987). Rosier and van Peteghem (1989) could indeed detect hydroxylated 2 -deoxyguanosine following exposure of this DNA-precursor to the "epigenetic" carcinogen diethylstilbestrol in vitro. These data indicate that biotransformation of BHA may be involved. Therefore, further experiments on the fate of BHA, in particular in man, should focus on the identification in body fluids of quinones and sulphur-containing metabolites formed out of BHA, in order to recognize a possible bioactivation pathway of BHA in vivo. 


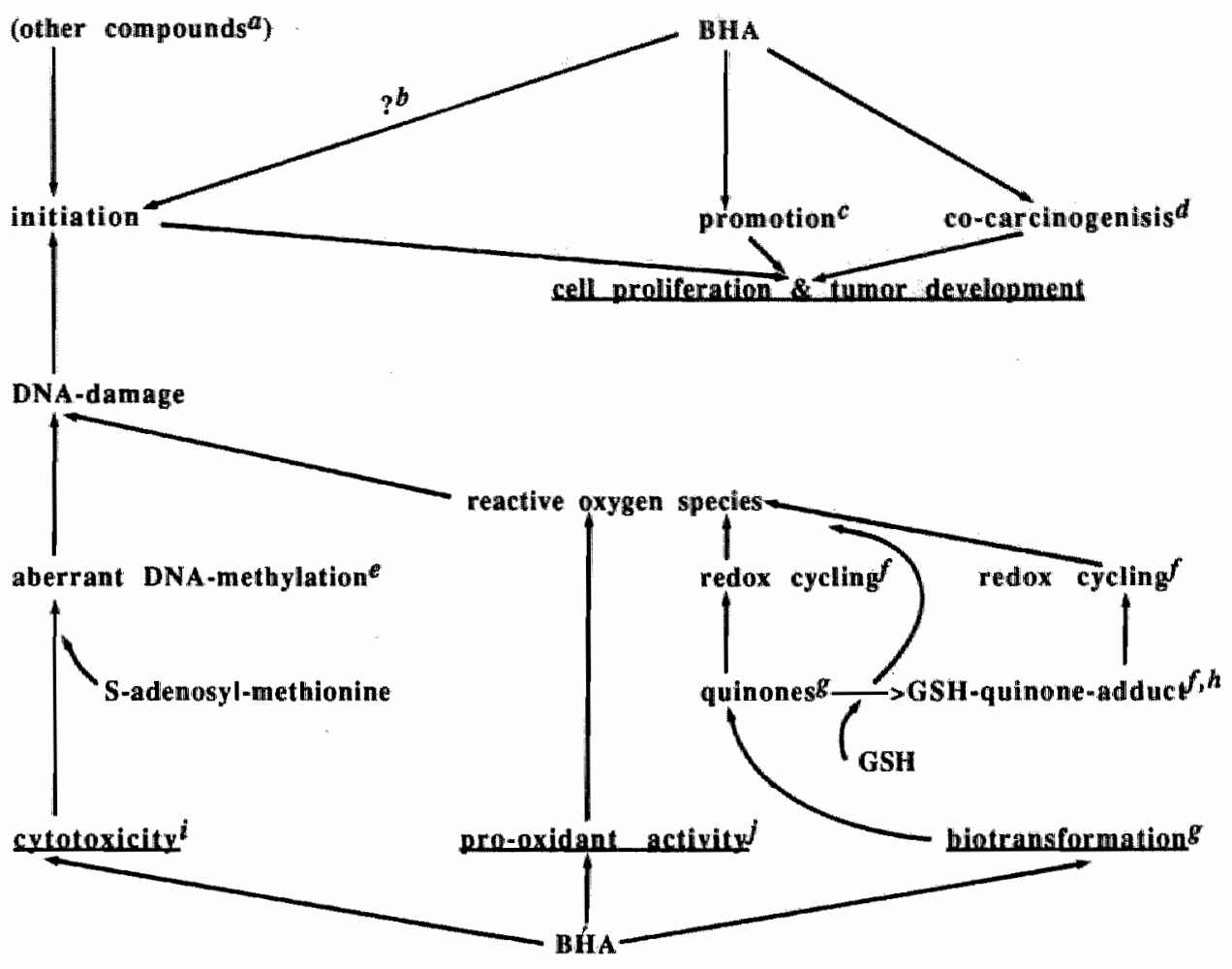

Figure 14-1. Unifying hypothesis for the passible mechanisms underlying the tumorigenicity and the induction of proliferative changes in digestive tract tissues of rodems, assuming initiating potential of BHA.

a exogenows initiators, endogenous intriators, increased spontaneous mutations: Kroes and Wester (1986); Grice el al. (1986); Blumenthal et ai. (1986).

b: Hypothesized; supported by several positive responses in short-term mutagenicity tests and by dato of Masui ef al. (1986. 1987), Abraham et al. (1986) and Sato et al. (1987).

c: Chapter 1: Imaida et al. 1983, 1984.

d. Strong irritating potential: Riley and Seal (1968); damaging effecrs on membranes: Williams (1986); Thompson and Moldéus (1988).

e: formation of $N^{7}$ - methylguanine and $0^{6}$-methylguamine; Shank and Barrows (1985).

f: Smith (1985).

g: e,g. tert-butylquinone and 3-tert-butyl-5-meshoxy-1,2-benzoquinone. Cytockrome P-450 -mediated andlor prostaglandin synthetase -mediated. Co-administration to rats of the prostaglandin synthetase inhibitor acetyl salicylic acid lowered BHA-induced increases in forestomach labelling index; Rodrigues ef al. (1986).

h: $G S H=$ glutathion; co-administration of the GSH depleting agent diethylmaleate inhibited BHA-induced forestomach hyperplasia in rats Hirose et al. (1987). Unknown sulphur-containing metabolites of BHA have been reported; Cummings et al. (1985); DeStajney et al. (1986).

i: Thompson and Moldéus (1988); Williams (1986).

$j$ : Kahl and Hildebrandi (1986). 
BHA is cytotoxic in in witro experiments with isolated rat hepatocytes (Thompson and Moldeus, 1988). Aberrant S-adenosyl-methionine-dependent DNA-methylation mediated by "epigenetic" carcinogens (e.g. the formation of N7-methyl- and 06-methyl-guanine adducts, which normally are not present in the DNA) has been proposed to result from cytotoxicity (Shank and Barrows, 1985).

Future research on the initiating potential of BHA is facilitated by the availlability of several high-performance liquid chromatographic methods for the quantitative determination of DNA-adducts formed by $\cdot$ OH radical hydroxylation (Kasai and Nishimura, 1984; Schraufstătter et al., 1988) and by methylation of DNA-nucleobases (Beranek et al., 1980; Herron and Shank, 1979; van Zeeland et al., 1985).

In addition to the quantization of hydroxylated and methylated DNA-adducts, effects of BHA on DNA should be subject of further research on the initiating potential of BHA. Damage to the genome, for instance by mutagenic chemicals forming adducts with the DNA, is recognized and subsequently repaired by a group of enzymes that are involved with normal functioning of cell replication. The most extensively used method to detect repairrelated DNA synthesis is to monitor incorporation of radio-labelled nucleotides, e.g. $\left[{ }^{3} \mathrm{H}\right]-$ thymidine, into the DNA. These tests for unscheduled DNA synthesis (UDS) measure aspecifically primary DNA damage, and they appear to respond to most classes of chemicals (Stich et al., 1981; Douglas et al., 1981; McCormick and Maher, 1981; Mohn et al., 1984; Venitt et al, 1986; McQueen et al., 1988). UDS-assays are performed in vitro with rat hepatocytes, human hepatocytes, or with human diploid fibroblasts (Douglas et al., 1981; McCormick and Maher, 1981; Venitt et al., 1986; Neis, 1986). However, also in vivo and in vivo/in vitro UDS assays have been described (Stich et al., 1981; Venitt et al., 1986; Longstaff, 1986). Since there are no data on DNA-damage due to BHA administration (Anonymous, 1986), tests for UDS should be performed. Furthermore, the in vitro measurement of UDS in (human) epithelial cells lining the lumen of the gastro-intestinal tract as reported by Mori et al. (1984) may be particularly relevant with respect to the effects of BHA in these tissues.

If DNA-repair processes do not take place, this may either result in point or frame-shift mutations or in events, like sister chromatid exchanges, DNA strand breaks, micronucleiformation, gene translocations and gene amplifications. Several, tests for these events, which may stand at the basis of the oncogenic response of BHA, are at present routine procedures (reviewed in Longstaff, 1986; Stich and San, 1981).

Further studies on BHA-induced effects on DNA should be performed by administration of BHA alone and by simultaneous administration of BHA and one or more compounds, capable of interacting with specific biochemical pathways (e.g. biotransformation). The involvement of bioactivation may be studied by co-administration of inhibitors of the cytochrome P-450- system (e.g. piperonyl butoxide) and of prostaglandin synthetase (e.g. indomethacin and acetyl salicylic acid). The proposed experiments on the carcinogenic mechanism of BHA should be performed in vitro using cultured cells and tissues, originating from animal and human origin. (Squamous) epithelial cells are to be preferred over other cell types, whenever possible. Although there is presently no in vitro system for studying the proliferative effects of BHA, the development of such a model may be a relevant progressive step in mechanistic research on $B H A$. In cell culture, a wide variety of studies are possible that might be impossible in the much more complex whole animal model. However, studies using the intact animal may provide valuable additional 
information on the direction of mechanistic research in vitro. For instance, in vivo experiments of Hirose et al. (1986, 1987 b), Rodrigues et al. (1986) and Abraham et al. (1986) indicate that the proliferative effects of BHA in rat forestomach disappear, decrease or increase upon the introduction of different stimuli.

In addition, the parenteral administration of BHA (e.g. by intraperitoneal or subcutaneous injection) may provide more information on the tissue-specificity of the growth stimulating effects of BHA and on the necessity of a direct contact between high doses of BHA and cells lining the lumen of the gastro-intestinal tract as well as on the predictive value of plasma BHA levels for its proliferation enhancing and tumorigenic effects in these tissues.

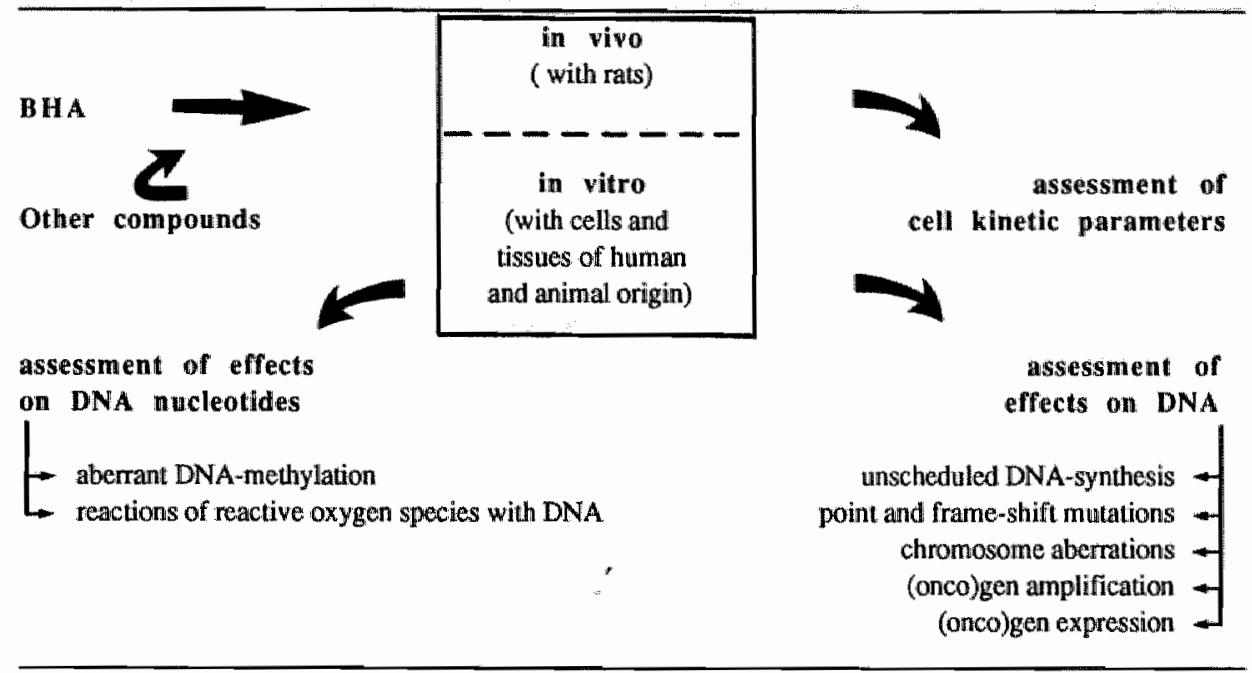

Figure 14-2. Proposal for furrher research on the mechanism of the carcinogenicity of BHA in rat forestomach, its proliferative effects in other gastro-imuestinal tract tissues, and its possible implications for mam.

Once the nature of the primary effect on DNA has been elucidated, dose-response studies should be performed and molecular dosimetry (e.g. DNA adduct formation) should quantitatively be compared to parameters for effects on DNA (e.g. unscheduled DNAsynthesis, point mutations, chromosome breaks, sister chromatid exchanges, gene amplification, gene expression), as well as to proliferation parameters (e.g. tissue labelling index) and finally tumor development. The better the correlation between parameters obtained on different levels of the proliferative and tumorigenic process, the more insight into the underlying mechanism is provided, and the better the possible implications of BHA consumption by man may be evaluated. Figure 14-1 gives a unifying hypothesis and illustrates the possible pathways for the initiating potential of BHA; in Figure 14-2 the proposals for further experiments on BHA are presented schematically. 
Similar studies as suggested for BHA should be performed with BHT, in order to elucidate the unknown mechanism of BHT-induced liver carcinogenesis in rodents. BHT is a complete carcinogen for rodent liver (chapter 1). Further, BHT is a well known tumor promotor (chapter 1; Imaida et al., 1983, 1984) and may be a co-carcinogen as well, possibly due to its effects on biomembranes (Thompson and Moldéus, 1988). In addition, there is "inadequate evidence" for genetic activity of BHT in short-term tests (chapter 9; Anonymous, 1986 b).

Several of the proposed mechanisms for the tumorigenicity of BHA may also be applicable to its structurally related compound BHT. BHT elicits cytotoxic activity (Thompson and Moldéus, 1988) which may stand att the basis of aberrant DNA-methylation. BHT possesses pro-oxidant activity (Kahl and Hildebrandt, 1986), which may give rise to reactive oxygen species. Moreover, metabolism of BHT involves the formation of a reactive quinone-like structure, 2,6-di-tert-butyl-4-methylene-2,5-cyclohexadienone (BHT-quinone-methide), which probably may react with cellular thiol groups and glutathion. BHT-quinone methide was found to be associated with liver toxicity in rodents (Nakagawa et al., 1984). As with BHA, it is postulated here that BHT gives rise to tumorigenicity in liver of rodents by inducing heritable changes in DNA. As with BHA the effects of BHT on individual DNA nucleotides and on DNA should be subjected to further investigation, both in in vivo and in in vitro experiments Obviously, the liver and liver cells should be the primary targets of investigation.

In conclusion , there are several reasons for concern with respect to the intake of BHA and BHT by man. Man disposes of BHA in a way that is very different from that in the rat and the estimated daily intake of BHT may exceed the ADI set for BHT. The major difficulty in risk assessment for BHA and BHT, however, is the unknown mechanism underlying their carcinogenicity in experimental animals. Future research should focus on the tumor-initiating potential of BHA and BHT.

\section{References}

- R. Abraham, K.F. Benitz, G. Patil and R. Lyon (1986). Rapid induction of forestomach tumors in partially hepatectomized Wistar rats given butylated hydroxyanisole. Exp. . Pathol. 44: 14-20.

- B. Alberts, D. Bray, J. Lewis, M. Raff, K. Roberts and J.D. Watson (1983). Molecular biology of the cell . Garland Publishing, New York and London, p. 180.

- Anonymous (1986a). Butylated hydroxyanisole (BHA). IARC Monographs on the ewaluation of the carcinogenic risk of chemicals to humans, 40:123-159.

- Anonymous $\left(1986^{b}\right.$ ). Butylated hydroxytoluene (BHT). IARC Monographs on the evaluation of the carcinogenic risk of chemicals to thumans. 40:161-206.

- D.T. Beranek, C.C. Weis and D.H. Swenson (1980). A comprehensive quantitative analysis of methylated and ethylated DNA using high pressure liquid chromatography. Carcinogenesis 1: 595-606.

- H. Blumenthal, J.W. Daniel, P.S. Elias, R.J. Scheuplein, V. Silano, A. Turturro and G. Vettorazzi (1986). Risk assessment associated with the use of phenolic antioxidants in foods. Food Chem. Toxicol. 24: $1243-1253$.

- J.J. McCormick and V.M. Maher (1981). Mutagenesis studies in diploid human cells with different DNA-repair capacities. in: H.F. Stich and R.H.C. San (Eds.). Short-term tests for chemical carcimogens. Springer Verlag, New York, Heidelberg, Berlin., p264-276.

- S.W. Cummings, G.A.S Ansari, F.P. Guengerich, L.S. Crough and R.A. Prough (1985). Metabolism of 3-tert-butyl-4-hydroxyanisole by microsomal fractions and isolated rat hepatocytes. Cancer Res. 45: $5617-5624$. 
- C.M. DeStafney, U.D.G. Prabhu, V.L. Spamins and L.W. Wattenberg (1986). Studies related to the mechanism of 3-BHA-induced neoplasia of the rat forestomach. Food Chem. Toxicol. 24: 1149-1157.

- G.R. Douglas, C.E. Grant, J.M. Wytsma and A. Chan (1981). Multi-well assay for unscheduled DNA synthesis using human diploid fibroblasts. in: H.F. Stich and R.H.C. San (Eds.). Short-term tests for chemical carcinogens. Springer Verlag, New York, Heidelberg, Berlin., p83-89.

- B.I. Ghanayem, R.R. Maronpot and H.B. Matthews (1986). Association of chemically induced forestomach cell proliferation and carcinogenesis. Cancer Lett. 32: 271-278.

- H.C. Grice, D.B. Clayson, W.G. Flamm, N. Ito, R. Kroes, P.M. Newberne, R. Scheuplein (1986). Possible mechanisms of BHA carcinogenicity from a consideration of its chemical and biological properties. Foad Chem. Toxicol. 24: 1235-1242.

- B.L. Harper and M.S. Legator (1987). Tumor promotors and genotoxic chemicals in short-term testing for carcinogenicity. Adlw. Vet. Sci. Comp. Med. 31: 1-19.

- D.C. Herron and R.C. Shank (1979). Quantitative high-pressure liquid chromatographic analysis of methylated purines in DNA of rats treated with chemical carcinogens. Anal. Biochem. 100: 58-63.

- M. Hirose, A. Hagiwara, T. Masui, K. Inoue and N. Ito (1986). Combined effects of butylated hydroxyanisole and other antioxidants in induction of forestomach lesions in rats. Cancer Lett. 30: 169174.

- M. Hirose, M. Asamoto, A. Hagiwara, N. Ito, H. Kanedo, K. Saito, Y. Takamatsu, A. Yoshitake and J. Miyamoto (1987 ). Metabolism of 2- and 3-tert-butyl-4-hydroxyanisole (2- and 3-BHA) in the rat (II): metabolism in forestomach and covalent binding to tissue macromoleculles. Toxicology 45: 13-24.

- M. Hirose, T. Inoue, A. Masuda, H. Tsuda and N. Ito ( $1987^{\mathrm{b}}$ ). Effects of simultaneous treatment with various chemicals on BHA-induced development of rat foretomach hyperplasia - complete inhibition by diethylmaleate in a 5-week feeding study. Carcinogenesis 8: 1555-1558.

- K. Imaida, S. Fukushima, T. Shirai, M. Ohtani, K. Nakanishi and N. Ito (1983). Promoting activities of butylated hydroxyanisole and butylated hydroxytoluene on two-stage urimary bladder carcinogenesis and inhibition of glutamyl transpeptidase-positive foci development in the liver of rats. Carcinogenesis 4: 895 .

- K. Imaida, S. Fukushima, T. Shiraii, T. Masuï, T. Ogiso and N. Ito (1984). Promoting activities of butylated hydroxyanisole, butylated hydroxytoluene, and sodium-L-ascorbate on forestomach and urinary bladder carcinogenesis initiated with methylnitrosurea in F344 male rats. Gann 75: 769-775.

- N. Ito, S. Fukushima, S. Tamano, M. Hirose and A. Hagiwara (1986). Dose response in butylated hydroxyanisole induction of forestomach carcinogenesis in F344 rats. J. Natl. Cancer Inst. 77: 12611265.

- R. Kathl and A.G. Hildebrandt (1986). Methodology for studying antioxidant activity and mechanisms of action of antioxidants. Food Chem. Toxicol. 24: 1007-1014.

- H. Kasai and S. Nishimura (1984). Hydroxylation of deoxyguanosine at the C.8 position by ascortbic acid and other reducing agents. Nucl. Acids Res. 12: 2137-2145.

- W.K. Kaufmann (1989). Pathways of human cell post-replication repair. Carcinogenesis 10: 1.11.

- R. Kroes (1987). Contribution of toxicology towards risk assessment of carcinogens. Arch. Toxicol. 60: 224-228.

- R. Kroes and P.W. Wester (1986). Forestomach carcinogens:possible mechanisms of action. Food Chem. Toxicol. 24: 1083-1089.

- E. Longstaff (1986). Genetic toxicology: a review. Adv. Drug React. Ac. Pois. Rev. 4: 235-255.

- T. Masui, M. Asamoto, M. Hirose, S. Fukushima and N. Ito (1986). Disappearance of upward proliferation and persistence of downward basal cell proliferation in rat forestomach papillomas induced by butylated hydroxyanisole. Gann $77: 854-857$.

- T. Masui, M. Asamoto, M. Hïrose, S. Fukushima and N. Ito (1987). Regression of simple hyperplasia and papillomas and persistence od basal cell hyperplasia in the forestomach of F344 rats treated with butylated hydroxyanisole. Cancer Res. 47: 5171-5174.

- G.R. Mohn, P.R.M. Kerklaan, A.A. van Zeeland, J. Ellenberger, R.A. Baan, P.H.M. Lohman and F.* W. Pons (1984). Methodologies for the determination of various genetic effects in permeable strains of E. coli K-12 differing in DNA repair capacity. Quantification of DNA adduct formation, experiments. with organ homogenates and hepatocytes, and animal-mediated assays. Mut. Res. 125: 153-184.

- H. Mori, F. Obbayashi, S. Sugie, T. Tanaka, M. Takahashi and N. Mori (1984). Measurement of unscheduled DNA synthesis on alkylating carcinogens in rat intestinal mucosal cells from different sites. J. Toxicol. Sci. 9: 23-28. 
- Y. Nakagawa, K. Tayama, T. Nakao and K. Hiraga (1984). On the mechanism of butylated bydroxy toluene-induced hepatic toxicily in rats. Biochem. Pharmacol. 33: 2669-2674.

- J. Neis (1986) Thesis. Catholic University of Nijmegen, The Netherlands.

- C.A. MCQueen, B.M. Way and G.M. Willams (1988). Genotoxicity of carcinogens in human hepatocytea: application in hazard assessment. Toxicol. Appl. Pharmacol. 96: 360-366.

- P.A. Riley and P. Seal (1968). Micro-invasion of epidermis caused by substituted anisoles. Nature 220: $922-923$.

- C. Rodrigues, E. Lok, E. Nera, F. Iverson, D. Page, K. Karpinski and D.B. Clayson (1986). Short-term effects of various phenols and acids on the Fischer 344 rat forestomach epithelium. Toxicology 38: 103 117.

- J.A. Rosier and CH. van Peteghern (1989). Peroxidative in vitro metabolism of diethylstilbestrol induces formation of 8-hydroxy-2"-deoxyguanosine. Carcinogenesis 10: 405-406.

- H. Sato, M. Takahashi, F. Funkkawa, Y. Miyakawa, R. Hasegawa, K. Toyodla and Y. Hayashi (1987). Initiating potentiall of 2-(2-furyl)-3-(5-nitro-2-furyl)acrylamide (AF-2), butylated hydroxyanisole (BHA), batylated hydroxytoluene (BHT) and 3,3,4",5,7-pentahydroxyflavone (quercetin) in two-stage mouse sikin carcinogenesis. Cancer Lett. 38: 49-56.

- I. Schraufstatter, P.A. Hyslop, J.H. Jackson and C.G. Cochrane (1988). Oxidant-induced DNA damage of target cells. J. Clin. Invest. 82: 1040-1050.

- R.C. Shank and L.R. Barrows (1985). Toxicological effects on carcinogenesis. in: Toxicological risk assessment. Biological and statistical criteria. (D.B. Clayson, D. Krewski and I. Munro, Eds.), vol. I, CRC Press, Boca Raton, FL, USA, p91-104.

- M.T. Smith (1985). Quinones as mutagens, carcinogens, and anticancer agents: introduction and overview. J. Toxicol. Environ. Health 16: 665-672.

- G.R. Stark and G.M. Wahl (1984). Gene amplification. Ann. Rev. Biochem. 53: 447-491.

- H.F. Stich and R.H.C. San (Eds.) (1981). Short-term tests for chemical carcinogens. Springer Verlag, New York, Heidelberg, Berlin.

- H.F. Stich, R.H.C. San and H.J. Freeman (1981). DNA repair synthesis (UDS) as an in vitro and in vivo bioassay to detect precarcinogens, ultimate carcinogens, and organotropic carcinogens. in: H.F. Stich and R.H.C. San (Eds.). Short-term tests for chemical carcinogens. Springer Verlag, New York, Heidelberg, Berlin.. p65-82.

- D. Thompson and P. Moldéus (1988). Cytotoxicity of butylated hydroxyanisole and butylated hydroxytoluene in isolated rat hepatocytes. Biochem. Pharmacol . 37: 2201-2207.

- D.C. Thompson and M.A. Trush (1988). Studies on the mechanism of enhancement of butylated hydroxytoluene-induced mouse lung toxicity by butylated hydroxyanisole. Toxicol. Appl. Pharmacol. 96: 122-131.

- S. Veniu, H. Bartsch, G. Becking, R.P.P. Fuchs, M. Hofnung, C. Malaveille, T, Matsushima, A.E. Pegg, M.R. Rajewsky, M. Roberfroid, H.S. Rosenkranz and G.M. Williams (1986). DNA damage and repair. in: Long-term and short-term assays for carcinogens: a critical appraisal. $(\mathbb{R}$. Montesano, $H$. Bartsch, H. Vaino, J. Wilbourn and H. Yamasaki, Eds.), IARC Scientific Publications No. 83, p129142.

- M. Vuillaume (1987). Reduced oxygen species, mutation, induction and cancer initiation. Mut. Res. 186: 43-72.

- G.M. Williams (1986). Epigenetic promoting effects of butylated hydroxyanisole. Food Chem. Toxicol. 24: $1163-1166$.

- A.A. van Zeeland, G.R. Mohn "A. Neuhäuser-Klaus and U.H. Ehling (1985). Quantitative comparison of genetic effects of ethylating agents on the basis of DNA adduct formation. Use of $0^{6}$-ethylguanine as molecular dosimeter for extrapolation from cells in culture to the mouse. Environ. Health Perspec. 62: 163-169. 


\section{Summary}

Butylated hydroxyanisole (BHA) and butylated hydroxytoluene (BHT) are widely used as food additives to prevent oils, fats and shortenings from oxidative deterioration. BHA and $\mathrm{BHT}$ are compounds of relatively low toxicity. However, BHA and BHT have both carcinogenic potential. BHA induces hyperplasia, papillomas and carcinomas in the forestomach of rats, hamsters and probably mice. In non-rodents (pigs, monkeys), in the oesophagus proliferation stimulating effects have been reported in response to BHA administration. BHT induces liver tumors in rats and mice. Due to general negative responses in short-term tests for genetic activity, BHA and BHT are considered to be nongenotoxic ("epigenetic") carcinogens. For this class of carcinogenic compounds a threshold for their tumorigenic effects is assumed to exist. Therefore, risk assessment for these food additives is based on the no effect level - safety factor approach. The subsequent establishment of an acceptable daily intake (ADI) for human consumption of BHA and BHT is performed by extrapolating on basis of a dose - body weight comparison of experimental animal vs man, which method does not take specific physiological differences between species in kinetics or biotransformation pathways into account.

This thesis sets out to improve the basis for the estimation of potential health risks associated with human dietary intake of BHA and BHT, focussing on the fate of BHA and BHT in man vs rat, on the mechanism underlying their tumorigenicity in laboratory animals, on the assessment of other target tissues in experimental animals, and on the daily exposure of man to these food additives.

In the introduction the current state of knowledge on BHA and BHT is briefly surveyed. Special emphasis is laid on their toxicity profiles. In part I of the thesis, two methods are presented for the quantitative determination of BHA and BHT in body fluids. Furthermore, a method is described for the rapid determination of the 2- and 3-BHA isomers in a batch. All methods involve high-performance liquid chromatography. In part II, the no-effect level - safety factor approach to determine an ADI for man, is compared with a more physiological approach, based on the concept of concentrations of an agent at (target) tissue sites, as is reflected by plasma levels. Plasma BHT concentrations after a single oral dose of $0.5 \mathrm{mg} / \mathrm{kg}$ in man and $20-200 \mathrm{mg} / \mathrm{kg}$ in rat were very different. In a similar experiment. plasma levels after administration of a single oral dose of BHA in man $(0.5 \mathrm{mg} / \mathrm{kg})$ and rat $(200 \mathrm{mg} / \mathrm{kg}$ ) were within one order of magnitude. In addition, more than $51 \%$ of the oral dose of BHA could not be recovered from urine and feces of man, unlike rat, indicating the possibility of bioaccumulation and/or unknown routes of biotransformation of BHA in man.

In order to investigate whether these results imply that oral ingestion of $0.5 \mathrm{mg} / \mathrm{kg} \mathrm{BHA}$ could induce effects in man, in part III, eight male volunteers ingested this amount of BHA daily for ten consecutive days. In this study, no effects of BHA administration were detected on standard clinical parameters or on general phase-I and -II biotransformation capacity in man. However, the amount of phase-I and -II metabolites of BHA excreted into urine gradually increased towards the end of the experiment. This could either be due to bioaccumulation of (metabolites of) BHA and/or to induction of BHA-specific 
biotransformation enzymes in man. This remains to be solved.

In part IV, BHA and BHT were found to possess no mutagenic activity in the Salmonella/microsome assay using new tester strains. In addition, it was shown that it is most unlikely that oxidative cytochrome P-450 -mediated metabolism of BHA into tertbutylhydroquinone is involved in the unknown mechanism underlying the induction of proliferation stimulating effects of BHA in experimental animals. In the forestomach of rats, an apparent no-effect level for ad libitum fed rats was found at $0.5 \%$ BHA in the diet (labelling index) and at $0.75 \% \mathrm{BHA}$ (potential doubling time). Further, in contrast to data reported by others, proliferation enhancing effects of BHA in other parts of the gastrointestinal tract of rat were detected, indicating that in this species not only the forestomach, but also the oesophagus, glandular stomach, small intestine and large bowel should be considered target tissues for BHA. Consequently, BHA affects not only squamous epithelial cells, but other cell types lining the lumen of the digestive tract as well.

In part $\mathrm{V}$, the maximal possible daily dietary intake of BHA and BHT in the Netherlands was estimated. It is shown that, based on a maximal-approach, it is unlikely that the ADI for BHA is surpassed by man, but that the ADI for BHT may be exceeded in all age and sex groups, and that particularly younger children form a potential risk group.

In conclusion, based on the estimated maximal daily dietary intake of BHA and BHT in the Netherlands in comparison with the current ADI's set for these food antioxidants, as concerns the application of BHA it is not probable that the ADI will be surpassed, unlike BHT. On the other hand, based on their fate in man vs rat, the application of BHT as a food additive may be considered safe, unlike BHA. However, in both instances risk assessment for the consumption of BHA and BHT by man is prone to uncertainties due to the fact that the mechanism underlying their carcinogenicity in rodents is still not understood. Moreover, in case of BHA, the need for further experiments on the unknown mechanism of carcinogenicity is emphasized by the finding that in rat also the oesophagus, glandular stomach, small intestine and colon/rectum should be considered to be potentially target tissues for the proliferation enhancing effects of BHA.

Several suggestions for further research are given. The assessment of the unknown mechanism of the proliferative and carcinogenic potential of BHA in gastro-intestinal tract tissues of laboratory animals, should have primary attention. Similarly, the mode of the carcinogenic action of BHT in the liver of rodents should be unraveled. Future experiments will focus on the induction of heritable changes in DNA, which is a prerequisite for tumor development. 


\section{Samenvatting}

Butylhydroxyanisol (BHA) en butylhydroxytolueen (BHT) zijn wijd-verbreide voedseladditieven, die gebruikt worden als antioxidant om het ranzig worden van vetten, oliën en vet-bevattende voedingsmiddelen tegen te gaan. De toxiciteit van BHA en BHT is relatief gering. Echter, zowel BHA als BHT zijn kankerverwekkend gebleken bij onderzoek met proefdieren. BHA induceert hyperplasiën, papillomen en carcinomen in de voormaag bij ratten, hamsters en waarschijnlijk ook bij muizen. In niet-knaagdieren, zoals varkens en apen, zijn in de slokdarm proliferatie verhogende effecten beschreven na toediening van BHA. BHT veroorzaakt levertumoren bij ratten en muizen. Omdat BHA en BHT in het algemeen negatieve resultaten laten zien in kortdurende testen voor genetische activiteit, worden BHA en BHT beschouwd als niet-genotoxische, zogenaamde "epigenetische", carcinogenen. Men neemt aan dat er voor deze klasse van chemische carcinogenen een drempelwaarde bestaat voor hun tumor-inducerende werking. Daarom is de risico schatting voor deze voedseladditieven gebaseerd op de geen-nadelig-effect-niveau / veiligheids factor benadering. Een aanvaardbare dagelijkse innerning (ADI) voor menselijke consumptie van BHA en BHT wordt vastgesteld door te extrapoleren op basis van de verschillen in lichaamsgewicht tussen proefdieren en de mens. Deze methode houdt echter geen rekening met specifieke fysiologische verschillen tussen soorten voor wat betreft kinetiek en biotransformatie.

Het doel van het in dit proefschrift beschreven onderzoek was een betere basis te verkrijgen voor het schatten van potentiële gezondheidsrisico's voor de mens bij dagelijkse inneming van BHA en BHT via het voedsel. Er werd vooral aandacht besteed aan de lotgevallen van BHA en BHT in de mens in vergelijking met de rat, aan het onbekende mechanisme dat ten grondslag ligt aan hun carcinogeniteit in proefdieren, aan het onderkennen van andere mogelijke doelwit-weefsels in proefdieren en aan de dagelijkse inneming van deze voedseladditieven door de mens.

In de inleiding wordt de huidige stand van de wetenschap over BHA en BHT in het kort beschreven, waarbij de nadruk is gelegd op hun toxicologische karakteristieken. In deel I van het proefschrift worden twee methoden gepresenteerd voor de kwantitatieve bepaling van BHA en BHT in lichaamsvloeistoffen. Bovendien wordt aangegeven hoe men eenvoudig en snel de verhouding van 2- en 3-BHA isomeren kan bepalen. Alle methoden maken gebruik van hoge-druk vloeistof chromatografie. In deel II wordt de geen-nadeligeffect-niveau / veiligheids factor benadering om een ADI voor de mens vast te stellen vergeleken met een meer fysiologische benadering, die gebaseerd is op de concentratie van een verbinding in het (doelwit) weefsel, welke weerspiegeld wordt door de gehaltes in het plasma. Na één enkele orale inneming van BHT door de mens $(0,5 \mathrm{mg} / \mathrm{kg})$ en door de rat (20-200 $\mathrm{mg} / \mathrm{kg}$ ) waren de concentraties van BHT in het plasma sterk verschillend. In een gelijksoortig experiment, waarbij de mens en de rat eenmalig een hoeveelheid BHA oraal kregen toegediend, respectievelijk 0,5 en $200 \mathrm{mg} / \mathrm{kg}$, lagen de gemeten gehaltes van BHA in het plasma van mens en rat binnen één grootte-orde. Bovendien kon bij de mens, in tegenstelling tot de rat, meer dan $51 \%$ van de dosis niet worden teruggevonden in urine en feces. Dit duidt op de mogelijkheid van bioaccumulatie en/of onbekende 
biotransformatieroutes van $\mathrm{BHA}$ bij de mens.

Om eventuelle implicaties van deze bevindingen voor de mens te bepalen werd in een experiment met acht mannelijke vrijwilligers nagegaan of orale inneming van BHA gedurende tien opeenvolgende dagen effecten teweegbracht (deel III). Er werden geen veranderingen gevonden in standaard klinische parameters of in de algemene fase-I en -II biotransformatiecapaciteit van de mens. De in de urine uitgescheiden hoeveelheid fase-I en II metabolieten van BHA was echter geleidelijk verhoogd tegen het einde van hel experiment. Dit kan enerzijds het gevolg zijn van opeenhoping van BHA of metabolieten daarvan in het lichaam of anderzijds van de inductie van specifieke BHA-metaboliserende enzymsystemen bij de mens. Dit zal nog nader onderzocht moeten worden.

In deel IV werd aangetoond dat BHA en BHT geen mutagene activiteit bezitten in de Salmonella/microsoom test. Voorts werd duidelijk dat het erg onwaarschijnlijk is dat metabole omzetting van BHA tot tert-butylhydrochinon via het cytochroom P-450 enzymsysteem betrokken is bij de inductie van proliferatie verhogende effecten van BHA in de voormaag van ratten. In de voormaag van ratten werd een schijnbaar geen-effect-niveau voor ad libitum gevoerde ratten gevonden bij $0.5 \%$ BHA in het voer voor het percentage delende cellen en bij $0.75 \%$ BHA voor de potentièle verdubbelingstijd van het weefsel. Voorts werden, in tegenstelling tot bevindingen van anderen, proliferatie verhogende effecten van BHA in andere delen van het spijsverteringskanaal van ratten waargenomen. Dit betekent dat in deze diersoort niet alleen de voormaag, maar ook de slokdarm, maag, dunne en dikke darm beschouwd moeten worden als doelwit-organen voor BHA. Tevens houdt dit in dat BHA niet alleen een effect heeft op plaveisel-epitheelcellen, maar ook op andere celtypen die de wand van het het maagdarmkanaal bekleden.

In deell $\mathrm{V}$ werd een schatting gemaakt van de maximale dagelijkse inneming van BHA en $\mathbb{B H T}$ via het voedsel in Nederland. Gebaseerd op een maximaal-benadering werd aangetoond dat het onwaarschijnlijk is dat men een hoeveelheid BHA binnenkrijgt die hoger is dan de ADI, maar ook dat de ADI voor BHT in alle leeftijdsgroepen en door beide sexen kan worden overschreden. Jonge kinderen vormen een potentiële risicogroep.

Er werd geconcludeerd dat, gebaseerd op de geschatte maximale dagelijkse inneming van BHA en BHT via de voeding in Nederland in vergelijking met de huidige ADI"s voor deze antioxidanten, de toepassing van BHA, maar niet van BHT, zodanig is dat de ADI niet overschreden zal worden. Op basis van hun lotgevallen in de mens vs de rat, daarentegen, kan het gebruik van BHT, maar niet dat van BHA, beschouwd worden veilig te zijn voor de mens. Voor beide voedseladditieven is echter de risicoschatting van hun consumptie door de mens onderhevig aan onzekerheden vanwege het feit dat het mechanisme van de carcinogeniteit ervan in knaagdieren niet bekend is. Bovendien wordt ingeval van BHA de vraag naar verdere experimenten omtrent het onbekende carcinogene werkingsmechanisme versterkt door het feit dat in de rat ook de slokdarm, de maag, de dunne en de dikke darm beschouwd kunnen worden als mogelijke doelwitorganen voor de proliferatie stimulerende effecten van BHA.

Tot slot worden suggesties gedaan voor verder onderzoek. Met name zal getracht moeten worden het onbekende mechanisme te ontrafelen dat ten grondslag ligt aan de inductie van proliferatie stimulerende en carcinogene effecten van BHA in het maag-darm kanaal van proefdieren. Eveneens dient de carcinogene werking van BHT in de lever van knaagdieren nader te worden onderzocht. Toekomstig onderzoek moet in eerste instantie gericht worden op de inductie van erfelijke veranderingen in het DNA, aamgezien die een voorwaarde zijn voor tumor-ontwikkeling. 


\section{Dankwoord}

In de loop van de jaren dat ik aan dit proefschrift heb gewerkt, heb ik met vele mensen samengewerkt. Enkelen van hen die in het bijzonder hebben bijgedragen aan de totstandkoming ervan wil ik hier noemen en danken.

In de eerste plaats Hanny natuurlijk .....

Dr. J.C.S. Kleinjans, mijn co-promotor en begeleider van het eerste uur. Jos, jouw bijdragen -zowel inhoudelijk als op de werkvloer- waren van wezenlijk belang. Ik heb onze talloze discussies over de uit te voeren experimenten, de te schrijven manuscripten en het ontwikkelen van nieuwe ideeën steeds erg gewaardeerd. Bovendien kun je je uitstekend inleven in de situatie van een promovendus.

Prof.Dr. F. ten Hoor en Prof.Dr. P.Th. Henderson, mijn beide promotoren. Foppe en Pie, ik kon steeds verzekerd zijn van een warme belangstelling voor en stimulerende discussies over mijn werk. Ik heb dankbaar gebruik gemaakt van jullie ervaring.

Prof.Dr. H.A.J. Struyker Boudier, Prof.Dr. P.J. Brombacher, Prof. Dr. V.J. Feron, Prof.Dr. R.J.J. Hermus en Dr. H.H.W. Thijssen, de leden van de beoordelingscommissie, hebben kritische kanttekeningen geplaatst en waardevolle suggesties gegeven, waardoor het proefschrift aan kracht heeft kunnen winnen. Dr. Thijssen ben ik daarnaast erkentelijk voor het feit dat ik $21 / 2$ jaar van zijn laboratorium gebruik mocht maken. Henk, het is heel prettig een 'echte' chemicus dicht in de buurt te hebben. In het proefschrift is veel van jouw inbreng terug te vinden.

Ir. G.J. Hageman, mijn kamermaatje. Geja, ik heb je collegialiteit steeds erg gewaardeerd. Talloze zaken over het onderzoek zelf en daarbuiten hebben wij samen besproken. Zonder jouw hulp was hoofdstuk 9 er nooit geweest.

Dr. B. Schutte, heeft mij wegwijs gemaakt op en gebruik laten maken van de flow cytometer, tevens stelde hij monoclonale antilichamen ter beschikking. Bert, jij hebt samen met Michèle Reynders vele uren gespendeerd aan het gebruiksklaar maken van de in hoofdstuk 10 beschreven en in hoofdstukken 11 en 12 toegepaste technieken - de reeks publicaties die hienit voort vloeit groeit nog steeds.

Rico H.G. Beckers en Lou M. Maas, stagiaires van de Jaboratoriumschool in Sittard, hebben talloze analyses uitgevoerd met hoge-druk vloeistof chromatografie. Zonder jullie gezwoeg had ik nooit zover kunnen komen.

Drs C. Furnée, hoofdvakstagiaire Biologische Gezondheidkunde. Carina, een groot gedeelte van de hoofdstukken 11 en 12 is jouw werk geweest. Voor het uitvoeren van de daarin beschreven proefdierexperimenten en bepalingen op flow cytometrisch en histologisch gebied had ik niet zonder jou gekund. 
Petra Comuth, Ingeborg Deerenberg en Anita Marx, bijvakstagiaires Biologische Gezondheidkunde, lewerden een korte maar krachtige bijdrage op chemisch-analytisch en voedingskundig terrein. Hun werk is vervat in de hoofdstukken 7 en 13.

Medewerkers van de Centrale Proefdier Voorziening. Frans Weekers voor de vele malen dat er een aanslag werd gedaan op onze reukorganen. Eep van Dam, Frans Weekers en Peter Kelderman voor het valkkundige biotechnische werk. Jos Knops, Huub Simons, Jo Wierts en Yvonne Derkx voor de speciale verzorging die mijn ratten gedurende de weekeinden nodig hadden.

Prof.Dr. Geert H. Blijham, Prof.Dr. Fré T. Bosman, Drs. Rob J.J. Hermans, Prof.Dr. Wim Saris, Dr. Djoeke van Dale, Drs. Adriaan de Bruine, Ed Beckers, Paul Schoffelen, Gerrit van Kranenburg, Leo Baars, Prof.Dr. B. Zwanenburg en Dr. K. Sekikawa wier inbreng bij verschillende hoofdstukken reeds recht gedaan is met een vermelding in de auteurslijst of de acknowledgements.

De proefpersonen die bereid waren hun kostbare bloed, speeksel, urine en/of feces te verzamelen, vaak gedurende meerdere dagen achtereen.

Loek Wouters, Ger Jansen, Paul Schiffers, Lily Vervoort en Marie-José Drittij met wie ik bijna dagelijks het traject Heerlen - Maastricht v.v. heb afgelegd.

Mary Peters, Ine Poolen en Truus Dickhaut voor de vele secretariële werkzaamheden.

Voorts alle leden van de vakgroepen Humane Biologie, Biologische Gezondheidkunde i.o., Farmacologie, Pathologie en Interne Geneeskunde voor hun aangename collegialiteit en immer aanwezige bereidheid tot samenwerking. 


\section{List of publications}

\section{Full papers}

- Weterings P.J.J.M., Verhagen H., Wirtz P. and Vermorken A.J.M. (1984) Differentiation of human scalp hair follicle keratinocytes in cullure.

Virchows Arch. (Cell Pathol) 45: 255-266.

- Vermorken A.J.M., Verhagen H., Vermeesch-Markslag A.M.G., Wirtz P., Bernard B.A.n. Asselincau D. Lenoir M.C. "Kimenai P.M. and Shroot B. (1985) Differentiation of keratinocytes in vitro: a new culture vessel mimicking the in vivo situation.

Molec. Biol. Rep. 10: 205-213.

- Vermorken A.J.M., Verhagen H. Goos C.M.A.A., Lenpir M.C. and Shroot B. (1985) Psoriatic hair follicle cells. II. Morphological differentiation of outer root-sheath cells in culture.

Differentiation 29: 182-188.

- Verhagen H., Thijssen H.H.W. and Kleinjans J.C.S. (1987) A sensitive high-performance liquid chromatographic method for the routine determination of butylated hydrox yanisole in plasma.

J. Chromatogr. 413: 282-286.

- Verhagen H., Thijssen H.H.W. and Kleinjans J.C.S. (1987) Determination of butylated hydroxytoluene in plasma by high-performance liquid chromatography.

J. Chromatogr. 422: 288-293.

- Kleinjans J., Verhagen H., Hageman G. and ten Hoor F. (1987) De carcinogeniteit van de voedingsniddelen additieven butylhydroxytolueen en butylhydrox yanisol. Een literatuurstudie.

Voeding 48: 153-157.

- Hageman G.J., Verhagen H. and Kleinjans J.C.S. (1988). Butylated hydroxyanisole, butylated hydroxytoluene and tert-butylhydroquinone are not mutagenic in the Salmonella/microsome assay using new tester strains.

Mutation Research 208: 207-211.

- Verhagen H., Schutte B., Reijnders M.M.J., Blijham G.H., ten Hoor F. and Kleinjans J.C.S. (1988) Effect of short-term dietary administration of butylated hydroxyanisole on cell kinetic parameters in rat gastro-intestinal tract, assessed by immunocytochemistry and flow cylometry.

Carcinogenesis 9: 1107-1109.

- Verhagen H., Van Agen B., Hageman G.J., Beckers R.H.G. and Kleinjans J.C.S. (1988) Determination of alpha-tocopherol levels in rat microsomes by high-performance liquid chromatography.

J. Liquid Chromatogr. 11: 2977-2982.

Verhagen H., Thijssen H.H.W., ten Hoor F. and Kleinjans J.C.S. (1989) Disposition of single oral doses of butylated hydroxyanisole in man and rat.

Food Chem. Toxicol. 27: 151-158.

Verhagen H. and Kleinjans J.C.S. (1989) Rapid determination of isomer ratios of butylated hydroxyanisole by high-performance liquid chromatography.

J. Chromatogr. 464: 438-441.

- Kleinjans J.C.S. Pluijmen M.H.M., Hageman G.J. and Verhagen H. (1989) Stabilization and quantitative analysis of fecapentaenes in human feces, using synihetic fecapentaene-12.

Cancer Let. 44: 33-37.

- Verhagen H., Maas L.M., Beckers R.H.G., ten Hoor F, Henderson P.Th. and Kleinjans J.C.S. (1989). Effects of subacute oral intake of the food antioxidant butylated hydroxyanisolle on clinical parameters and phase-l and -II biotransformation capacity in man.

Human Toxicology (in press).

- Verhagen H., Furnée C. Schutte B., Hermans R.J.J., Blijham G.H., Bosman F., ten Hoor F., Henderson P.Th. and Kleinjans J.C.S. (1989). Butylated hydroxyamisole-induced alterations in cell kinetic parameters in rat forestomach in relation to its cytochrome P-450- mediated metabolism. Carcinogenesis (in press).

- Verhagen H. and Kleinjans J. (1989). Toxicologie van de voedseladditiewen BHA en BHT. Giftig (in press).

- Verhagen H. and Kleinjans J.C.S. Biliary excretion of butylated hydroxyanusole in the rat. Food Chem. Toxical. (in press). 
Verhagen H., Beckers R.H.G., Comuth P.A.W.V., Maas L.M., ten Hoor F., Henderson P.Th. and Khleinjaris J.C.S. Disposition of single oral doses of butylated thydroxytoluene in man and rat.

Food Chem. Toxicoll, (in pressi).

Verhagen $H_{v}$, Furnee $\mathrm{C}$, Schutte B., Bligham G.H., Bosman F, Henderson P.Th., ten Hoor F. and Kleinjans J.C.S. Dose-dependent effects of shont-term dietary administration of the food additive butylated hydroxyanisole on cell kinetic parameters in the gastro-intestinal tract of malle Wistar rats. Submitued for publication.

- Verkagen H., Decrenberg I., Marn A., ten Hoor F, Henderson P.Th. and Kleinjans J.C.S. Estimate of the thaximal daily dietary intake of butylated thydroxyanisole and butylated hydroxytoluene in the Netherlands.

Submitted for publication.

\section{Abstracts}

Verhagen H., Wirz P., Lenoir M.C., Kimenai P.M., Shroot B. and Vermorken A.J.M. (1984) Psoriatic and control human hair follicle keratinocytes in culture.

Ultramicroscopy 14: $417-418$.

Verhagen H., Thijssen H.H.W. and Kleinjans J.C.S. (1987) Metabolism and kinetics of 2(3)-tert-butyl4-hydroxyanisole in man and rat.

Pharmac. Weekbl. Sci. Ed. 9: 45.

Hageman G., Verhagen H. and Kleinjans I.C.S. (1987) Non-mutagenicity of butylated thydroxyanisole, butylated hydroxytoluene and tert-butylhydroquinone in the Salmonella/microsome assay using new tester sirains.

Pharmac. Weekbl. Sci, Ed. 9: 41.

- Verhagen H., Thijssen H.H.W. ten Hoor F. and Kleinjans J.C.S. (1987) Comparison of the disposition of single oral doses of $\mathrm{BHA}$ and $\mathrm{BHT}$ in man and rat.

Pharmac. Weekbl. Sci. Ed. 10: 301.

- Verhagen H., Schutte B., Reijnders M.M.J., Blijham G.H., ten Hoor F. and Kleinjans J.C.S. (1987) A two-week feeding study of $\mathrm{BHA}$ : effect on cell kinetic parameters in the rat gastro-intestinal tract. Pharmac. Weekbi. Sci. Ed. 9: 356.

- Verhagen H., Thijssen H.H.W. and Kleinjans J.C.S. (1988) Fate of the food additive butylated hydroxyanisole in man and rat.

Human Toxicology 7: 70 .

- Kleinjans J.,Van Agen B., Verhagen H., Hageman G. and ten Hoor F. (1988) Interaction of the food

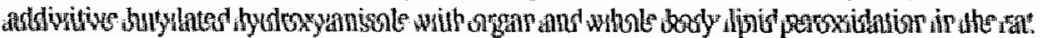

Human Toxicology $7: 81$.

- Furnee C., Verhagen H., Schutte B., Reynders M.M.J., Blijham G.H., ten Hoor F. and Kleinjans J.C.S. (1989) A short-term dose-response study on the effects of butylated hydroxyanisole on cell kinetic parameters in the gastro-intestinall tract of male Wistai rats.

Pharmac. Weekbl. Sci. Ed. 11: B6.

Verhagen H., Beckers R.H.G., ten Hoor F. and Kleinjans J.C.S. (1989) Fate of the food additive butylated hydroxytoluene in man and rat.

Pharmac. Weekbl. Sci. Ed. 11: B13.

- Verhagen H., Maas L.M., Beckers R.H.G., ten Hoor F. and Kleinjans J.C.S. (1989). Subacute administration of butylated hydroxyanisole to men: no effects on clinical plasma parameters and phase I and -ll metabolic capacity.

Pharmac. Weekbl . Sci. Ed. 11: B13.

Verhagen H., ten Hoor F. and Kleinjans J.C.S. (1989). Metabolism and kinetics of the food additives BHA and BHT in relation to their carcinogenicity.

Pharmac. Weekb]. Sci. Ed. 11: G3.

- Verhagen H., Furnee C., Schute B. and Kleinjans J.C.S. Increased labelling indices in rat gastrointestinal tract tissues following 14 days of oral butylated hydroxyanisole administration.

in: Basic science in toxicology. Proceedings of the 5th international congress of toxicology, Brighton, UK, 16-2॥ July 1989. (G.N. Volans, J. Sims and P. Turner, Eds.). Taylor \& Francis, London, New York, Philadelphia. p1 10. 


\section{Curriculum vitae}

Franciscus Johannes Josephus (Hans) Verhagen werd geboren op 23 november 1957 te Helmond. In 1976 behaalde hij het gymnasium- $\beta$ diploma aan het St. Willibrord College te Deurne. Daarna starte hij met de studie Scheikunde aan de Katholieke Universiteit te Nijmegen. In 1979 behaalde hij het kandidaatsdiploma (S1). De doctoraalfase werd in 1983 afgesloten en bestond uit het hoofdvak Farmacochemie/Toxicologie (Prof,Dr. J.M. van Rossum, Prof.Dr. P.Th. Henderson) en de bijvakken Cel Biologie (Prof.Dri. E.L. Benedetti, Université de Paris V, Parijs, Frankrijk) en Biochemie (Prof.Dr. H. Bloemendal, Prof.Dr. A.J.M. Vermorken). Van 1983 tot 1985 was hij werkzaam als wetenschappelijk assistent aan de Katholieke Universiteit te Nijmegen bij de Werkgroep voor Cellulaire Differentiatie en Transformatie (Prof.Dr. A.J.M. Vermorken). Sedert 1985 is hij als wetenschappelijk assistent werkzaam aan de Rijksuniversiteit Limburg te Maastricht bij de vakgroep Humane Biologie/Biologische Gezondheidkunde i.o. (Prof.Dr. F. ten Hoor, Dr. J.C.S. Kleinjans) alwaar het onderzoek zoals beschreven is in dit proefschrift werd uitgevoerd. Vanaf $1989 \mathrm{zal}$ hij als universitair docent verbonden zijn aan dezelfde vakgroep. 